UNIVERSIDADE DE SÃO PAULO

FACULDADE DE ECONOMIA, ADMINISTRAÇÃO E CONTABILIDADE

DEPARTAMENTO DE CONTABILIDADE E ATUÁRIA

PROGRAMA DE PÓS-GRADUAÇÃO EM CIÊNCIAS CONTÁBEIS

COMPETIÇÃO NO MERCADO PRODUTOS, GOVERNANÇA CORPORATIVA E DESEMPENHO DAS COMPANHIAS

Pedro Henrique de Barros

Orientador: Prof. Dr. Alexandre Di Miceli da Silveira

SÃO PAULO

2010 
Prof. Dr. João Grandino Rodas

Reitor da Universidade de São Paulo

Prof. Dr. Reinaldo Guerreiro

Diretor da Faculdade de Economia, Administração e Economia

Prof. Dr. Edgard Bruno Cornachione Júnior Chefe do Departamento de Contabilidade e Atuária

Prof. Dr. Luís Eduardo Afonso Coordenador do Programa de Pós-Graduação em Ciências Contábeis 
PEDRO HENRIQUE DE BARROS

\section{COMPETIÇÃO NO MERCADO DE PRODUTOS, GOVERNANÇA CORPORATIVA E DESEMPENHO DAS COMPANHIAS}

Dissertação apresentada ao Departamento de Contabilidade e Atuária da Faculdade de Economia, Administração e Contabilidade da Universidade de São Paulo como requisito para a obtenção do título de Mestre em Ciências Contábeis.

Orientador: Prof. Dr. Alexandre Di Miceli da Silveira 


\section{FICHA CATALOGRÁFICA}

Elaborada pela Seção de Processamento Técnico do SBD/FEA/USP

\begin{tabular}{|l}
\hline \\
Barros, Pedro Henrique de \\
Competição no mercado de produtos, governança corporativa e desem- \\
penho das companhias / Pedro Henrique de Barros. -- São Paulo, 2010. \\
193 p. \\
Dissertação (Mestrado) - Universidade de São Paulo, 2010. \\
Orientador: Alexandre Di Miceli da Silveira. \\
1. Governança corporativa 2. Competição econômica 3. Desempenho \\
organizacional I. Universidade de São Paulo. Faculdade de Economia, \\
Administração e Contabilidade II. Título. \\
CDD - 658.4
\end{tabular}


À minha mãe, pelos diversos sacrifícios feitos ao longo da minha criação. 
A conclusão da dissertação só foi possível graças a diversas contribuições recebidas ao longo do curso de mestrado. Inicialmente, agradeço à Fipecafi pela bolsa concedida, por meio de seu Centro de Estudos em Governança Corporativa, bem como por toda infra-estrutura oferecida.

Ao Prof. Dr. Alexandre Di Miceli da Silveira tenho imensa gratidão por todo o apoio ao longo do curso de mestrado. Precisaria de mais espaço para agradecê-lo. Contudo, aqui expresso toda a minha admiração por sua capacidade intelectual, postura acadêmica e caráter. Sem dúvidas, é um exemplo a ser seguido. Ainda, acrescento que além de proeminente em governança corporativa, o Prof. Di Miceli consegue tempo para estudar as "Raízes do Brasil" e entender "O Povo Brasileiro". Muito obrigado, o senhor foi absolutamente fantástico!

Ao Prof. Dr. Luis Eduardo Afonso, que aceitou participar em minha banca de mestrado e contribuiu com diversas críticas e sugestões na banca de qualificação. Ademais, agradeço muito por suas excelentes aulas e pela paciência com as minhas constantes incursões em sua sala. Seu profissionalismo é um exemplo para mim.

Ao Prof. Dr. Cláudio Ribeiro de Lucinda, que também aceitou participar em minha banca de mestrado e contribuiu com valiosas sugestões no exame de qualificação e gentilmente cedeu dados sobre competição, que foram muito importantes para os testes da dissertação.

À equipe da Melhores \& Maiores agradeço por ter cedido dados relevantes para os desenvolvimentos iniciais da pesquisa. Ao Instituto Brasileiro de Geografia e Estatística, Instituto Brasileiro de Governança Corporativa e aos professores Ricardo Leal e André Carvalhal-da-Silva também agradeço pela cessão de dados relevantes para a consecução da pesquisa.

Aos professores Gerlando Augusto Sampaio Franco Lima, Iran Siqueira Lima, Lucas Ayres Barreira de Campos Barros, Luiz Paulo Lopes Fávero agradeço pelo auxílio e oportunidades de aprendizado.

Fabiano Gabriel, José Elias Feres de Almeida, Rafael Liza Santos e Sarah Chinarelli contribuíram com críticas e sugestões específicas ao trabalho.

Mario Armando Fernandes, profissional da Fipecafi, teve um papel muito importante. Apoiou-me e proporcionou totais condições para que eu desenvolvesse meus estudos. Sou muito grato ao senhor. Também não poderia deixar de agradecer aos demais profissionais da Fipecafi, com os quais convivi durante um excelente período. Muito obrigado!

Pela amizade e apoio, agradeço aos amigos: Altino Carvalho, Diana Almeida, Josué Pires Braga, Marcos Vinícius, Patrícia Costa, Rodrigo Carvalho, Rodrigo Pinto. Especialmente, agradeço ao sócio e amigo Renato Ferreira Leitão Azevedo pelo companheirismo e ajuda na execução do trabalho, muito obrigado! Também agradeço especialmente a Paulo César Siqueira e Luiz Distadio, pois me ajudaram em uma fase muito difícil.

Agradeço também à melhor nutricionista do mundo, Beatriz de Oliveira Carvalho. Muito obrigado por toda a sua paciência, compreensão e companheirismo ao longo desses trinta meses. Você é uma pedra preciosa e raríssima.

Marlene de Souza Monteiro, minha madrinha, e Eduardo Alberto Monteiro (in memoriam), meu padrinho, foram fundamentais em minha formação. Os agradeço de coração por tudo que fizeram por mim. Vocês são parte da minha vida. A Eduardo e Fernando Monteiro também devo sinceros agradecimentos.

Minha mãe, Roseneide Evangelista, e meu filhinho, Pedrinho, são as minhas fontes de inspiração constantes para seguir em frente e sempre persistir. Tudo que faço é sempre pensando em vocês. Acordar cedo e às vezes nem dormir é pouco perante tudo aquilo que vocês merecem. Muito obrigado por existirem e fazer meus dias muito felizes!!!

Por fim, agradeço a Deus por ser tão bondoso comigo e guiar-me na tomada das melhores decisões. Obrigado pela saúde, proteção, disposição, sabedoria e por ter colocado pessoas tão boas em meu caminho. 
"Ele um dia me disse Que chegava lá Olha aí! Olha aí!" (Chico Buarque de Holanda) 


\section{RESUMO}

Esta dissertação investiga de forma pioneira no Brasil os efeitos da competição no mercado de produtos sobre a qualidade da governança corporativa. O período de análise foi de 2005 a 2007, com uma amostra de 90 empresas no período. A pesquisa foi dividida em duas partes inter-relacionadas. A primeira investiga se as variáveis de competição no mercado de produtos impactam de forma significativa a qualidade de governança das companhias. Como aproximação da qualidade de governança, foi utilizado um índice de governança adotado pelo Instituto Brasileiro de Governança Corporativa. Como aproximação para competição no mercado de produtos, foram utilizadas diversas medidas, tais como o Índice de HerfindahlHirschmann, a razão de concentração das quatro principais empresas do mercado e o número de competidores. Os resultados, embora não conclusivos em virtude da ausência de significância estatística de algumas variáveis explicativas relativas à competição, sugerem no geral que a competição influencia a qualidade de governança corporativa. Em síntese, as análises indicam que quanto menor o grau de competição no mercado de produtos, menor a qualidade de governança corporativa das companhias. A segunda parte investiga se o impacto da qualidade da governança corporativa sobre o desempenho das companhias varia em função do grau de competição no mercado de produtos. No geral, observou-se que a qualidade de governança corporativa afeta positiva e significantemente o desempenho das companhias quando estas operam em setores menos competitivos. Contudo, os resultados não podem ser considerados conclusivos, em função da ausência de significância estatística das variáveis explanatórias principais em todas as regressões. No geral, os resultados da pesquisa contribuem para os pesquisadores da área ao discorrer sobre uma nova variável que pode afetar a definição da estrutura de governança das companhias e que, portanto, pode ser utilizada em modelos estatísticos: a competição no mercado de produtos. A pesquisa também contribui com o debate sobre definições de políticas de governança corporativa pelos órgãos reguladores. 


\begin{abstract}
As a pioneer in Brazil, this dissertation investigates how product market competition (PMC) effects on the corporate governance quality. The analysis frame coincides with the period from 2005 to 2007 , with a total sample of 90 companies. The research was divided into two interrelated parts. The first one investigates how PMC variables significantly impact the quality of corporate governance. In order to estimate the corporate governance quality, we used a governance index developed by the Brazilian Corporate Governance Institute. As a proxy for PMC, several measures were used, such as the Herfindahl-Hirschman Index, the concentration ratio of the four major companies in the market and the number of competitors. The mean results of these tests, though not conclusive because of the absence of statistical significance for some explanatory variables related to competition, in general suggest that competition influences the quality of corporate governance. In summary, the analysis indicates that companies with low PMC have lower corporate governance quality. The second part investigates if the impact of corporate governance quality on organizational performance varies depending on the degree of PMC. Overall, it was observed that the quality of corporate governance positively and significantly affects organizational performance when they operate in less competitive sectors. However, the results can not be considered conclusive due to the absence of statistical significance for the main explanatory variables in all regressions. Overall, the research results contribute to academicians and practitioners to discuss a new variable that can affect the corporate governance structure definition and therefore can be used in statistical models: product market competition. The research also contributes to the debate on corporate governance and policies development by regulatory agencies.
\end{abstract}




\section{SUMÁRIO}

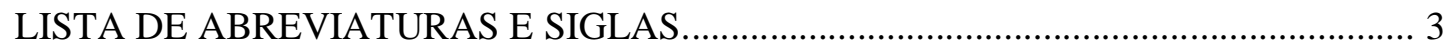

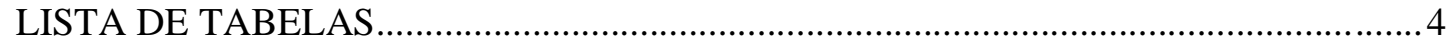

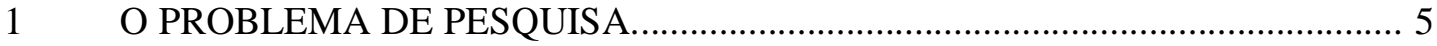

1.1 Introdução e formulação da situação-problema............................................ 5

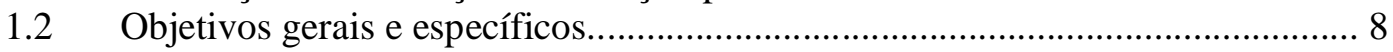

1.3 Problemas e hipóteses da pesquisa............................................................ 9

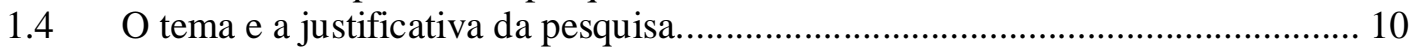

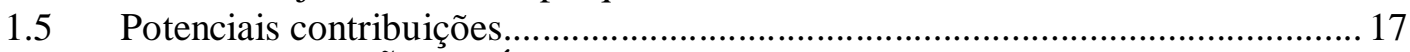

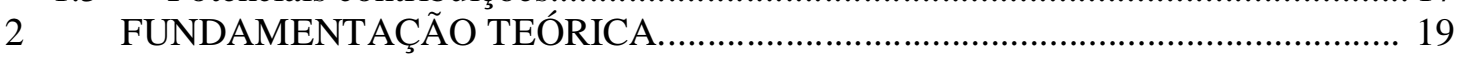

2.1 Governança corporativa: algumas considerações............................................. 19

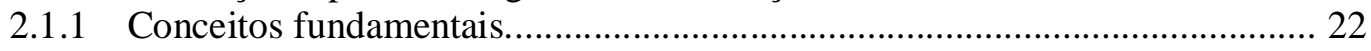

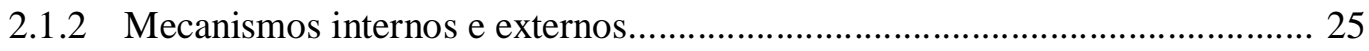

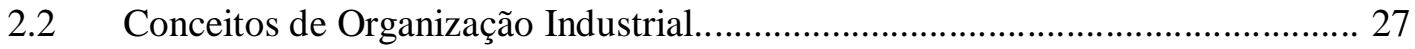

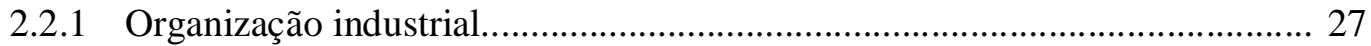

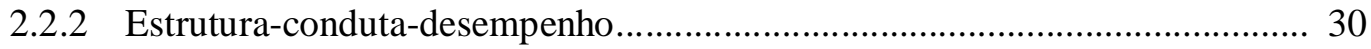

2.2.3 Competição no mercado de produtos................................................................ 33

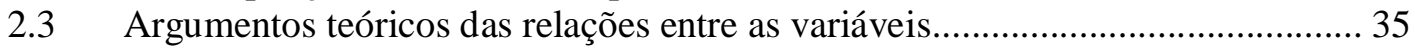

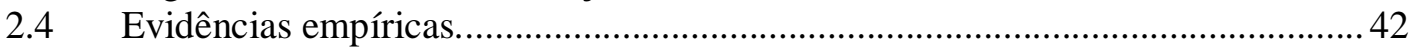

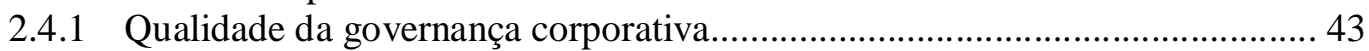

2.4.2 Grau de incentivo oferecido aos gestores.................................................. 44

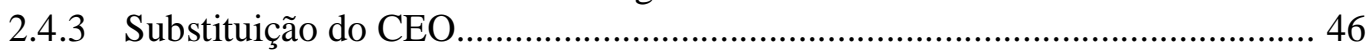

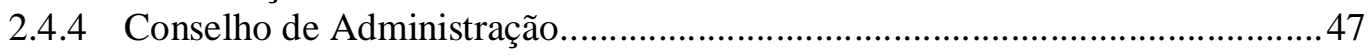

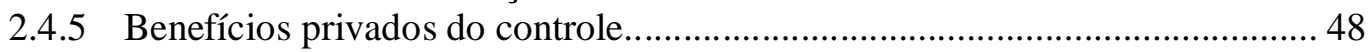

2.4.6 Utilização de cláusulas antitakeovers........................................................ 50

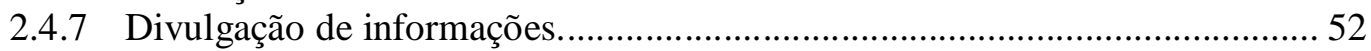

2.4.8 Política de distribuição de dividendos........................................................... 53

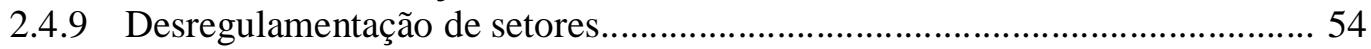

2.4.10 Competição, governança e valor................................................................... 56

2.4.11 Competição, governança e desempenho........................................................59

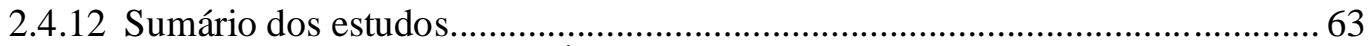

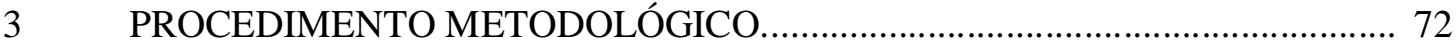

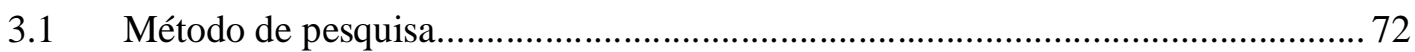

3.2 Definições teórica e operacional das variáveis-chave......................................... 72

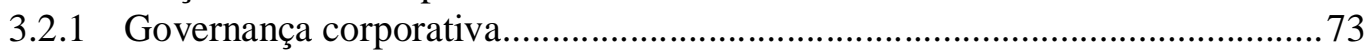

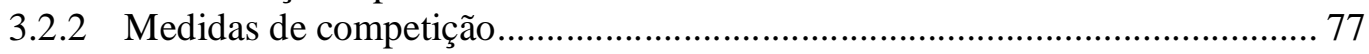

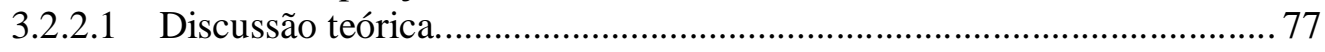

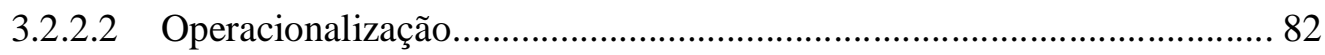

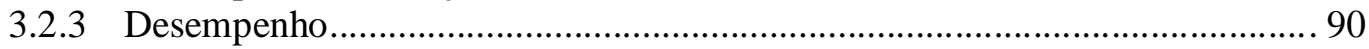

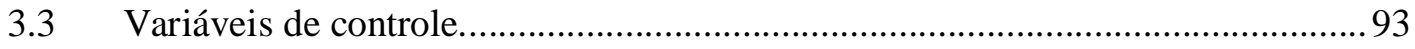

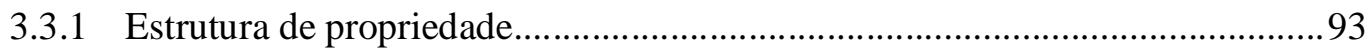

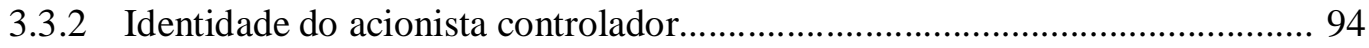

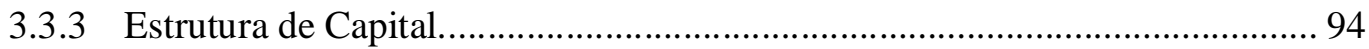

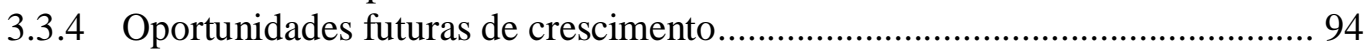

3.3.5 Níveis diferenciados de governança da BM\&FBOVESPA............................ 94

3.3.6 Emissão de American Depositary Receipts (ADRs)....................................... 94 


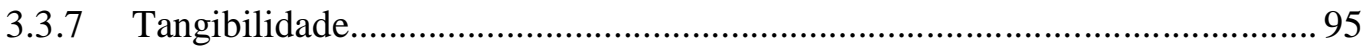

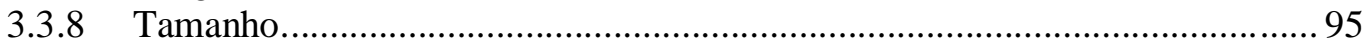

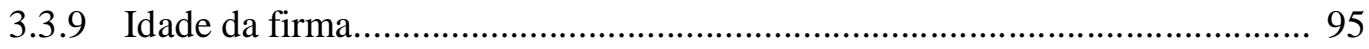

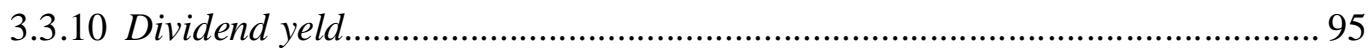

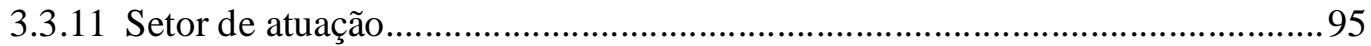

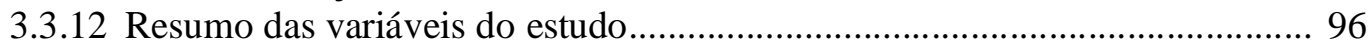

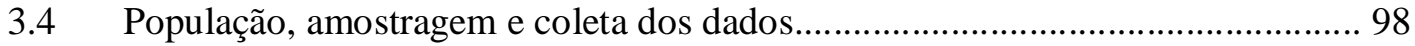

3.5 Modelos, tratamento estatístico e análise de dados.......................................... 100

3.6 Diagnósticos dos modelos e estimadores robustos dos erros-padrão......................104

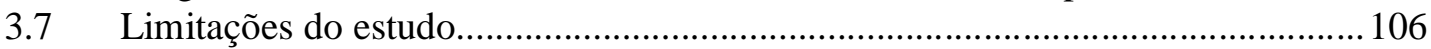

3.7.1 Amostra de empresas e período de tempo estudado.................................... 107

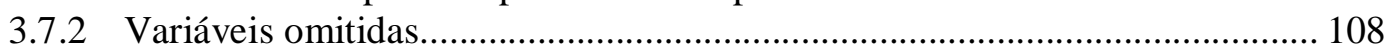

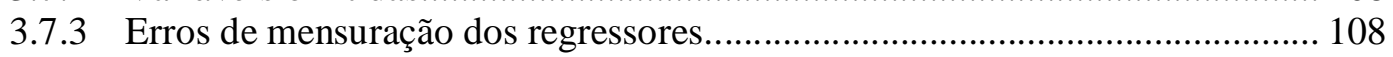

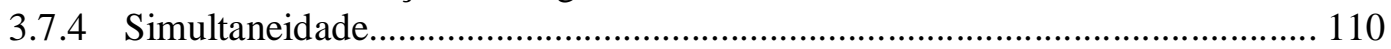

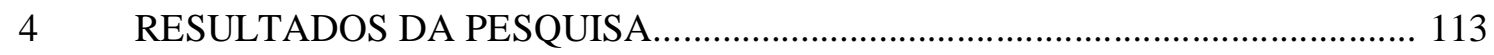

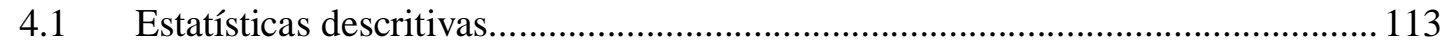

4.2 Efeitos da competição sobre a qualidade de governança corporativa.................... 121

4.3 Efeitos da interação entre competição governança sobre o desempenho.............. 139

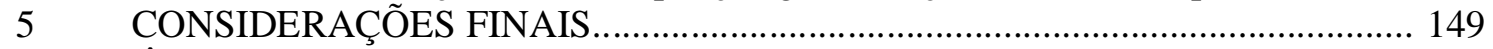

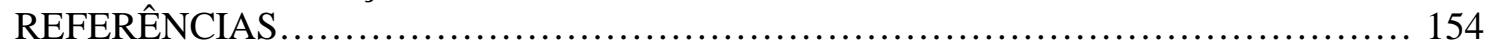

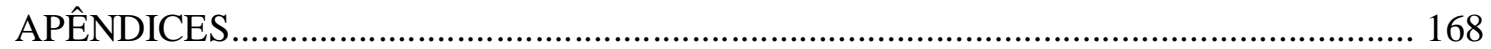

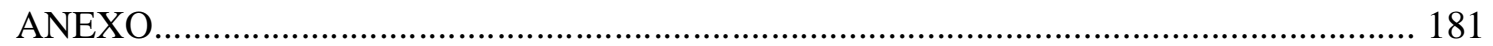




\section{LISTA DE ABREVIATURAS E SIGLAS}

ADR: American Depositary Receipts

BM\&FBOVESPA: Bolsa de Valores, Mercadorias e Futuros

CADE: Comitê Administrativo de Defesa Econômica

CNAE: Classificação Nacional de Atividades Econômicas

CNPJ: Cadastro Nacional da Pessoa Jurídica

CONCLA: Comissão Nacional de Classificação

DCP: Dual Class Premium

ECD: Estrutura-Conduta-Desempenho (ECD)

EA: Efeito aleatório

EF: Efeito fixo

GICS: Global Industry Classification Standard

GMI: Governance Metrics International

GMM-Sys: Método dos Momentos Generalizados Sistêmico

HHI: Índice de Herfindahl-Hirschman

IBGC: Instituto Brasileiro de Governança Corporativa

IBGE: Instituto Brasileiro de Geografia e Estatística

IPCM: Industry Adjusted Price-Cost Margin

MQO: Mínimos Quadrados Ordinários

NAICS: North-American Industry Classification System

OCDE: Organização para Cooperação e Desenvolvimento Econômico

OI: Organização Industrial

PAC: Pesquisa Anual do Comércio

PAS: Pesquisa Anual dos Serviços

PCM: Price Cost-Margin

PIA: Pesquisa Industrial Anual

PMR: Product Martket Regulation

POLS: Pooled Ordinary Least Square

SDE: Secretária de Direito Econômico

SEAE: Secretária de Acompanhamento Econômico

SIC: Standard Industrial Classifcation 


\section{LISTA DE TABELAS}

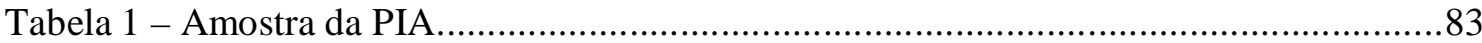

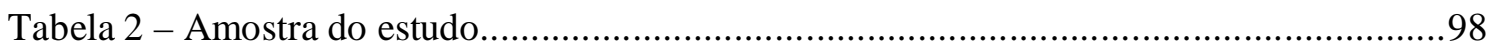

Tabela 3 - Estatísticas descritivas da variável IGOV e subíndices......................................113

Tabela 4 - Estatísticas descritivas das proxies de competição ........................................... 115

Tabela 5 - Estatísticas descritivas das proxies de desempenho........................................... 116

Tabela 6 - Estatísticas descritivas das demais variáveis de controle ................................117

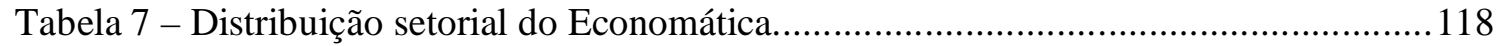

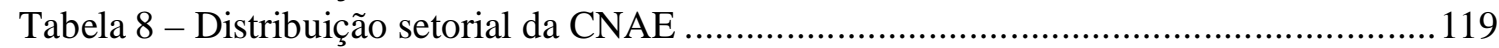

Tabela 9 - Distribuição do tipo de acionista controlador .................................................... 120

Tabela 10 - Empresas emissoras de ADRs e/ou listadas nos segmentos diferenciados de

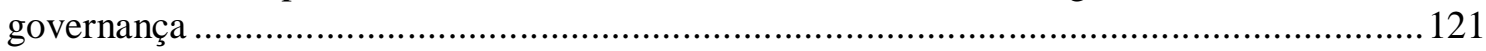

Tabela 11 -Matriz de correlação entre proxies de competição e governança corporativa .....124

Tabela 12 - Valores de corte das variáveis de competição ...............................................126

Tabela 13 - Testes de diferenças de médias .................................................................... 128

Tabela 14 - Efeitos da competição no mercado de produtos sobre a qualidade de governança das companhias: regressões utilizando o método MQO ...................................................130

Tabela 15 - Efeitos da competição no mercado de produtos sobre a qualidade de governança das companhias: regressões utilizando o método de Efeitos Aleatórios ..............................132 Tabela 16 - Efeitos da competição no mercado de produtos sobre a qualidade de governança das companhias: regressões utilizando o método de Efeitos Fixos .....................................134 Tabela 17 - Efeitos sobre a governança corporativa no período de 2005 a 2007: teste generalizado de Hausman para comparação dos estimadores de EA e EF...........................135 Tabela 18 - Efeitos sobre a governança corporativa no período de 1998 a2004: teste de Breusch-Pagan e teste generalizado de Hausman para comparação dos estimadores de EA e $\mathrm{EF}$

Tabela 19 - Efeitos da competição no mercado de produtos sobre a qualidade de governança das companhias: regressões utilizando o método de Efeitos Fixos para o período de 1998 a 2004

Tabela 20 - Efeito marginal da qualidade de governança corporativa sobre o desempenho: regressões utilizando o método de Efeitos Fixos para o período de 2005 a 2007 e critério da mediana para separação dos setores 144 Tabela 21 - Efeito marginal da qualidade de governança corporativa sobre o desempenho: regressões utilizando o método de Efeitos Fixos para o período de 2005 a 2007 e critério dos tercis para separação dos setores 146

Tabela 22 - Efeito marginal da qualidade de governança corporativa sobre o desempenho: regressões utilizando o método de Efeitos Fixos para o período de 2005 a 2007 e critérios do DOJ e CADE. 


\section{O PROBLEMA DE PESQUISA}

\subsection{Introdução e formulação da situação-problema}

A competição entre firmas é associada à alocação eficiente de recursos, em função da pressão exercida sobre os preços a fim de que convirjam ao custo marginal (AHN, 2002, p. 4), ao incremento no desempenho econômico por meio do aumento da produtividade, (HOJ et al., 2007, p. 5; OCDE, 2002, p. 1), ao crescimento da renda per capita (HOJ et al., 2007, p. 6) e à capacidade de inovação da economia como um todo (PORTER, 1990; NICKELL, 1996; BOONE; DIJK, 1998).

Especificamente, o nível de competição no mercado de produtos $^{1}$ é considerado um importante determinante dos incentivos dos gestores e do comprometimento organizacional (SCHIMIDT, 1997, p. 191). Karuna (2008, p. 2) define competição como “[...] o nível de esforço exigido das firmas para ganhar negócios de seus concorrentes na indústria". 2 Ahn (2002) cita que a pressão competitiva pode aumentar (reduzir) o comprometimento (desleixo) por meio de seu efeito disciplinador exercido sobre gestores e demais empregados da companhia, ao pressioná-los a aumentar a eficiência das operações da companhia. Shleifer e Vishny (1997, p. 738) complementam, destacando que a competição age como uma importante força no sentido de direcionar as firmas a um incremento na eficiência de suas operações. Fama (1980, p. 289) expõe que a firma é disciplinada pela competição exercida por outras firmas, cujo resultado é a necessidade de monitoramento mais eficiente do desempenho de todo o time de empregados da companhia, como também do monitoramento individual dos empregados.

Nickell et al. (1997) apresentam três meios pelos quais o efeito disciplinador da competição pode ocorrer. Inicialmente, ela faz com que o desempenho dos agentes seja comparado ao de

\footnotetext{
${ }^{1}$ Tradução literal da expressão Product Market Competition. Nesta pesquisa, utiliza-se de forma intercambiável com a denominação concisa "competição".

2 "[...] as the extent to which firms attempt to win business from their rivals in the industry".
} 
seus pares, diminuindo a assimetria informacional e possibilitando comparações. Outro canal seria a oportunidade de obter maiores lucros por meio do aumento de produtividade, dado que uma redução de custos em um mercado altamente competitivo tenderia a aumentar o lucro da companhia ${ }^{3}$. Por fim, há o risco de falência de uma firma sujeita a mercados mais competitivos. O temor de uma potencial falência poderia então estimular gestores e demais empregados a serem mais eficientes, considerando que a falência afetaria diretamente a renda extraída por eles. Tirole (2006, p. 28-29) vai ao encontro das idéias de Nickell et al. (1997), afirmando que a competição no mercado de produtos possibilita a comparação de desempenho entre agentes econômicos, além de afetar os incentivos dos gestores por meio da possibilidade de falência da companhia decorrente da perda de mercado para os concorrentes. Em síntese, os estudos indicam que a competição age como uma ferramenta de seleção das companhias mais eficientes, cujo resultado é o efeito disciplinador sobre gestores e demais empregados.

Não obstante, Kedia (2006, p. 876) afirma que os tradicionais modelos de finanças geralmente ignoram a competição no mercado de produtos e seus efeitos no valor de mercado da firma, enquanto Ali et al. (2008) afirmam que é crescente o número de estudos que investigam a relevância da variável competição no mercado de produtos sobre variáveis financeiras e econômicas.

Os trabalhos recentes que levam em consideração a competição no mercado de produtos como potencial variável relevante para explicar decisões empresariais inserem-se em diversas linhas de pesquisas, entre as quais: decisões sobre estrutura de capital (CHEVALIER, 1995); utilização de variáveis não financeiras para a tomada de decisão (IBRAHIM et al., 2001); estudos sobre responsabilidade social corporativa (FERNÁNDEZ-KRANZ; SANTALÓ, 2008); retorno das ações (HOU; ROBINSON, 2006); conservadorismo contábil (DHALIWAL et al, 2008) decisão de a empresa listar suas ações em bolsa (CHEMMANUR; HE, 2009) e ocorrência de insider trading no mercado de capitais (PERESS, 2008).

Alguns trabalhos também têm se dedicado à compreensão dos ganhos de eficiência advindos do efeito disciplinador da competição no mercado de produtos sobre os custos de agência.

\footnotetext{
${ }^{3}$ Em ambientes de alta competição a elasticidade da demanda tende a ser maior.
} 
Entre eles, destacam-se os de Hart (1983), Scharsfstein (1988), Hermalin (1992), Schimidt (1997), Aghion et al. (1999), Griffith (2001), Baggs e Bettignies (2006) e Chhaochharia et al. (2009). Analisados em conjunto, os trabalhos demonstram que a competição no mercado de produtos incentiva os gestores e demais empregados da companhia a despenderem maiores esforços no sentido de maximizarem o valor da companhia.

Da exposição acima, depreende-se que o grau de competição no mercado de produtos é um potencial determinante das estruturas de governança corporativa adotadas pelas companhias. Paredes (2005, p. 35) afirma que os acionistas são protegidos primariamente por mecanismos adicionais à legislação, como contratos, forças de mercado e normas de boas práticas e condutas que os gestores da companhia devem seguir. Entre as forças de mercado, o autor elenca a competição no mercado de produtos, que serve como um mecanismo de proteção aos acionistas. $\mathrm{O}$ autor afirma, ainda, que as forças de mercado mitigam o problema de agência por meio da punição de gestores e conselheiros negligentes quanto a maximização do valor da companhia para o acionista.

Shleifer e Vishny (1997, p. 738) afirmam que a competição no mercado de produtos é um mecanismo de governança importante, na medida em que induz os gestores a alocar eficientemente os recursos. Entretanto, também reconhecem que ele não é suficiente para mitigar completamente os custos decorrentes do problema de agência. Maher e Andersson (2000, p. 2) coadunam esta visão, ao expor que a competição no mercado de produtos isoladamente não consegue solucionar falhas no mercado, como assimetria de informação e o problema agente-principal, cerne das discussões sobre governança corporativa. Tirole (2006, p. 29) corrobora a opinião dos autores, ao afirmar que a competição não substitui totalmente estruturas de governança corporativa apropriadas.

Todavia, para Allen e Gale (1999) a competição no mercado de produtos atua como um mecanismo substituto dos tradicionais mecanismos de governança corporativa. Para esses autores, companhias submetidas a ambientes mais competitivos conduziriam seus negócios de forma a maximizar seu valor de mercado e, dessa forma, os problemas advindos do relacionamento entre agente e principal seriam mitigados, tornando os mecanismos de governança menos necessários em mercados mais competitivos. Alguns estudos empíricos respaldam o trabalho teórico desenvolvido por Allen e Gale (1999). Como exemplo, Giroud e 
Mueller (2008) encontram evidências de que os mecanismos de governança corporativa afetam significativamente o valor e o desempenho operacional da companhia apenas em ambientes menos competitivos, sugerindo existir um relacionamento de substituição entre competição no mercado de produtos e governança corporativa.

As idéias apresentadas conduzem ao raciocínio de que a variável competição no mercado de produtos é relevante nos estudos sobre governança corporativa, em função do potencial impacto sobre os conflitos de agência presentes nas companhias. Dentro dessa mesma temática, a discussão sobre a complementaridade ou substituição entre competição e governança também surge, na medida em que trabalhos teóricos e evidências empíricas apontam que a relevância da governança corporativa sobre o desempenho das companhias é positivo apenas em ambientes menos competitivos. Com o intuito de debater essa temática no mercado brasileiro, a presente pesquisa estuda de forma pioneira o impacto da competição no mercado de produtos sobre a qualidade de governança corporativa das companhias e, adicionalmente, se o efeito da governança sobre o desempenho varia em função do grau de competição no mercado de produtos.

\subsection{Objetivos gerais e específicos}

Grande parte dos estudos empíricos assume implicitamente que os mecanismos de governança são variáveis exógenas, isto é, não são determinados nem por outros mecanismos de governança e nem por características específicas da firma. (SILVEIRA; BARROS, 2007, p. 3). No entanto, caso isto não ocorra e os mecanismos de governança sejam variáveis endógenas, tais estudos podem ter produzido resultados inconsistentes sobre o relacionamento entre os mecanismos de governança e desempenho das companhias.

Karuna (2008) e Gillan et al. (2006) destacam que os atributos da estrutura de mercado podem influenciar os custos de agência e, por conseguinte, determinar as escolhas de mecanismos de governança corporativa pelas companhias. Entre os atributos da estrutura de mercado, Karuna (2008) destaca o nível de competição no mercado de produtos, em função de diversos estudos documentarem o importante papel desempenhado pela competição sobre as estratégias e desempenho das firmas. 
Como resultado, o objetivo geral da pesquisa é investigar a eventual relação entre a competição no mercado de produtos e a qualidade de governança corporativa das firmas no mercado brasileiro.

Além do objetivo geral, a pesquisa também possui alguns objetivos específicos, a saber:

i) verificar empiricamente se competição e governança corporativa são mecanismos substitutos ou complementares;

ii) testar estatisticamente se há diferenças significativas entre a qualidade de governança corporativa de companhias em setores mais ou menos competitivos;

iii) consolidar os estudos teóricos e evidências empíricas provenientes de diversos mercados que representem o estado da arte sobre a relação entre competição, governança corporativa e desempenho;

\subsection{Problemas e hipóteses da pesquisa}

Em relação às questões de pesquisa, Kerlinger (1980, p. 35) discute os atributos de um genuíno problema de pesquisa científica. $\mathrm{O}$ autor afirma que um problema de pesquisa científica deve ser apresentado por uma sentença interrogativa, buscar compreender a relação entre fenômenos e, por fim, implicar possibilidade da realização de testes empíricos.

Concernente às hipóteses, Sampieri et al. (2006, p. 122) afirmam ser proposições sobre a relação entre variáveis, podendo ser duas ou mais. Kerlinger (1980, p. 38) complementa este conceito ao ressaltar a necessidade de as hipóteses serem testáveis, pois uma hipótese intestável não tem utilidade científica.

Portanto, as questões e hipóteses desta pesquisa seguiram as recomendações dos autores citados e foram estruturadas da seguinte forma:

Questão 1 - A competição no mercado de produtos afeta significativamente a qualidade de governança corporativa das companhias brasileiras com ações listadas na BM\&FBOVESPA? 
$\mathrm{H}_{0,1}$ - (hipótese nula, questão 1): o nível de competição no mercado de produtos não afeta significativamente a estrutura de governança corporativa das companhias brasileiras listadas em bolsa .

$\mathrm{H}_{1,1}$ - (hipótese alternativa 1, questão 1): o nível de competição no mercado de produtos afeta significativa e positivamente a estrutura de governança corporativa das companhias brasileiras listadas em bolsa.

$\mathrm{H}_{2,1}$ - (hipótese alternativa 2, questão 1): o nível de competição no mercado de produtos afeta significativa e negativamente a estrutura de governança corporativa das companhias brasileiras listadas em bolsa.

Questão 2 - O efeito da governança corporativa sobre o desempenho das companhias brasileiras com ações listadas na BMF\&BOVESPA depende do grau de competição no mercado de produtos?

$\mathrm{H}_{0,2}$ - (hipótese nula, questão 2): o efeito da governança corporativa sobre o desempenho das companhias não depende do grau de competição no mercado de produtos.

$\mathrm{H}_{1,2}$ - (hipótese alternativa 1, questão 2): o efeito da governança corporativa sobre o desempenho das companhias é positivo quando o grau de competição no mercado de produtos é baixo.

$\mathrm{H}_{2,2}$ - (hipótese alternativa 2, questão 2): o efeito da governança corporativa sobre o desempenho das companhias é positivo quando o grau de competição no mercado de produtos é alto.

$\mathrm{H}_{3,2}$ - (hipótese alternativa 3, questão 2): o efeito da governança corporativa sobre o desempenho das companhias é negativo quando o grau de competição no mercado de produtos é baixo

$\mathrm{H}_{4,2}$ - (hipótese alternativa 4, questão 2): o efeito da governança corporativa sobre o desempenho das companhias é negativo quando o grau de competição no mercado de produtos é alto.

\subsection{O tema e a justificativa da pesquisa}


O tema foi definido por meio da observação simultânea de três atributos importantes para um trabalho acadêmico elencados por Castro (1978, p. 55), a saber: i) importância; ii) originalidade; e iii) viabilidade.

Para apresentar a importância da pesquisa e, por conseguinte, sua justificativa, responder-se-á o seguinte questionamento: Por que é relevante estudar a relação entre competição no mercado de produtos, governança corporativa e desempenho?

Vários estudos analisaram separadamente os impactos da governança corporativa e da competição no mercado de produtos sobre a alocação eficiente de recursos, melhoria no desempenho operacional das companhias e crescimento econômico.

No caso da governança corporativa, diversos trabalhos desta linha de pesquisa apontam para uma relação positiva entre melhores práticas de governança, alto desempenho e incremento do valor da firma. Como exemplos, Klapper e Love (2002), em um estudo com 374 empresas de 14 países, concluem que há alta correlação positiva entre qualidade da governança corporativa, desempenho operacional e valor de mercado. Beiner et al. (2004), em um estudos com empresas suíças, obtêm forte correlação positiva entre qualidade de governança corporativa e valor de mercado das empresas. Brown e Caylor (2006) realizam um estudo com 2.327 empresas americanas e concluem que empresas com melhores níveis de governança corporativa são mais bem avaliadas pelo mercado. Na Coréia do Sul, Black et al. (2006) analisam 525 empresas e concluem que governança corporativa é uma variável importante na predição do valor da firma. Bai et al. (2003) analisam 1.004 empresas chinesas e encontram que investidores pagam um prêmio relevante por empresas com boas práticas de governança corporativa. Em âmbito nacional, Leal e Carvalhal da Silva (2005) utilizam um painel de empresas de 1998-2002 e encontram como evidência uma relação positiva e estatisticamente significativa entre governança corporativa e valor de mercado das companhias. Silveira e Barros (2007) desenvolvem estudo com o mesmo propósito com 154 empresas brasileiras e também concluem haver relação estatisticamente significativa entre melhores práticas de governança corporativa e incremento no valor da empresa ${ }^{4}$.

\footnotetext{
${ }^{4}$ Todos os estudos apresentados utilizaram índices especificamente desenvolvidos para mensurara qualidade de governança corporativa.
} 
Além dos benefícios microeconômicos proporcionados por melhores práticas de governança, outros trabalhos têm avaliado seus potenciais benefícios macroeconômicos. Paredes (2005, p. 39) expõe a importância de se garantir os direitos dos acionistas. Segundo o autor, a proteção aos acionistas encoraja investimentos, o desenvolvimento do mercado de capitais e, como conseqüência, estimula o crescimento econômico. Rajan e Zingales (2004) também exploram a importância do respeito à propriedade privada como um incentivo ao desenvolvimento do mercado de capitais. Adeoye (2007) testa empiricamente se o nível de governança corporativa de um país tem relação com a atração de investimentos estrangeiros diretos em 33 países emergentes $^{5}$, utilizando o período de 1997 a 2002. O principal resultado é que, quanto maior a governança corporativa dos países emergentes, maior a atração de novos investimentos estrangeiros. Maher e Andersson (2000) realizam amplo levantamento bibliográfico de estudos sobre países da Organização para Cooperação e Desenvolvimento Econômico (OCDE), examinando evidências sobre a eventual existência de relação entre mecanismos de governança, desempenho e crescimento econômico. Os autores concluem que a governança corporativa afeta positivamente o desenvolvimento e funcionamento do mercado de capitais e exerce alta influência sobre a alocação eficiente de recursos.

Claessens (2003, p. 14), por meio de ampla revisão da literatura, discute cinco canais pelos quais governança corporativa afeta o crescimento e desenvolvimento econômico. O primeiro é pelo aumento do acesso ao capital externo pelas empresas, levando a aumento de investimentos, aumenta da taxa de crescimento e maior geração de empregos. O segundo seria por meio da diminuição do custo de capital, aumentando o valor das empresas e, por conseguinte, tornando-as mais atrativas para os investidores. O terceiro canal seria por meio do melhor desempenho operacional como conseqüência do aprimoramento das decisões de alto nível e melhor alocação de recursos. A mitigação de riscos de crises financeiras seria o quarto canal. Por fim, o quinto canal seria o aperfeiçoamento do relacionamento com os diversos stakeholders.

Em relação à linha de pesquisa sobre competição no mercado de produtos, geralmente observa-se que a competição está associada à alocação eficiente de recursos, além de atuar

\footnotetext{
${ }^{5} \mathrm{O}$ trabalho incluiu países como: Brasil, China, México, Rússia, Turquia entre outros.
} 
como um importante mecanismo de incentivo para minimizar o risco de relaxamento gerencial (FAMA, 1980; HART, 1983; NICKELL, 1996; MAYERS, 1996). Januszewski et al. (2001), em estudo com empresas alemãs, concluem que as empresas sujeitas a mercados de competição mais intensa obtêm altas taxas de crescimento, resultando em melhor desempenho. Griffith (2001), Grosfeld e Tressel (2001), Li e Niu (2006) e Pattanayak (2008) chegam a resultados similares em pesquisas conduzidas no Reino Unido, Polônia, China e Índia, respectivamente, reforçando a idéia de que a competição no mercado de produto impacta positivamente o desempenho das companhias. Tal é a importância de manterem-se níveis de concorrência ente setores, que grande parte dos países possui órgãos específicos para avaliarem atos de concentração ou quaisquer outros eventos entre companhias que possam causar substanciais alterações no ambiente competitivo do setor ${ }^{6}$.

A inter-relação entre esses dois campos do conhecimento pode ser ilustrada por meio do trabalho de Borsch-Supan e Koke (2000). Os autores discutem alguns problemas econométricos que podem surgir em pesquisas sobre governança corporativa decorrentes da ausência de variáveis relevantes. Segundo os autores, a competição no mercado de produtos é uma variável geralmente desconsiderada nos estudos sobre governança corporativa. De acordo com Borsch-Supan e Koke (2000, p. 11), assumindo que o modelo verdadeiro possa ser escrito como:

$$
y=\alpha+\beta x+\gamma z+\varepsilon
$$

em que:

$\mathrm{y}=$ lucro da firma;

$\mathrm{x}=$ posse de ações da firma pelos gestores ${ }^{7} ; \mathrm{e}$

$\mathrm{z}=$ grau de competição a que a firma está submetida no mercado de produtos.

\footnotetext{
${ }^{6}$ No Brasil, o Comitê Administrativo de Defesa Econômica (CADE) realiza essa função.

${ }^{7}$ Essa variável representa um mecanismo de governança corporativa, na medida em que objetiva alinhar os interesses dos gestores com os interesses dos acionistas.
} 
Se alguma análise objetivar estudar a relação entre a posse de ações da firma pelos gestores e o lucro da firma (y) sem considerar a competição no mercado de produtos (z), o coeficiente seria estimado da seguinte forma:

$$
\hat{\beta}=\beta+\gamma \frac{\operatorname{cov}(x, z)}{\operatorname{var}(x)}
$$

O coeficiente $\hat{\beta}$ não seria enviesado apenas se (1) $\gamma=0$ ou (2) a covariância entre $\mathrm{x} \mathrm{e} \mathrm{z}$ fosse zero. Assim, prosseguem os autores, se um alto grau de competição levar a firma a ter um desempenho inferior (com $\gamma$ negativo) por meio da redução do lucro, a competição seria um fator de redução de custos de agência, cujo resultado seria a menor necessidade de mecanismos de governança corporativa. Esse raciocínio sugere existir uma potencial relação negativa entre governança corporativa e competição no mercado de produtos, cujo significado formal é $\operatorname{cov}(\mathrm{x}, \mathrm{z})<0$. Portanto, se nenhuma métrica de competição no mercado de produtos for incluída na regressão, o impacto do $\beta$ da variável $\mathrm{x}$, que representa a posse de ações por parte dos gestores, seria superestimado. A discussão realizada pelos autores reforça a idéia de que a competição no mercado de produtos é relevante quando se estuda a estrutura de governança das companhias.

Karuna (2008) apresenta duas justificativas para o estudo da relação entre governança e competição. A primeira se daria do ponto de vista econométrico: examinar as relações de governança do ponto de vista da indústria reduziria a endogeneidade presente em grande parte dos estudos que vale-se apenas de atributos da firma. A segunda refere-se ao cerne das discussões sobre governança: segundo o autor, é razoável pensar que companhias em indústrias monopolísticas ou menos competitivas prefeririam menores custos de agência, sendo que o mesmo raciocínio vale para companhias em indústrias mais competitivas. Entretanto, considerando a diferença entre as estruturas de mercado, a estrutura de governança corporativa ótima de cada companhia poderia ser diferente.

Em adição aos aspectos acima expostos, Claessens (2003, p. 10) discute o papel da competição no mercado de produtos sobre a disciplina na gestão das companhias. De acordo com o autor, a competição é um importante fator para prevenir problemas de governança 
corporativa, já que as firmas sujeitas a um maior nível de competição teriam maior probabilidade de ajustarem seus aspectos operacionais e de gestão rumo à maximização do valor. Como resultado, os problemas de governança corporativa poderiam ser menores na presença de alta competição no mercado de produtos. $\mathrm{O}$ autor complementa seu argumento afirmando haver poucas evidências estruturadas sobre o assunto. Assim, tal relação constituise em um fértil campo para realização de pesquisas empíricas.

$\mathrm{Na}$ presente pesquisa, o arcabouço teórico para fundamentar a relação acima é extraído dos estudos da tradicional Organização Industrial (OI), especificamente do modelo de EstruturaConduta-Desempenho (ECD). O paradigma ECD parte do pressuposto que a forma como um determinado setor ou indústria está estruturado determina a conduta da firma e, por conseguinte, reflete em seu desempenho (KUPFER e HASENCLEVER, 2002). Logo, dentro desse paradigma, o estudo da estrutura de um setor ou indústria é um fator importante para a compreensão do comportamento e práticas adotadas pelas firmas. Este estudo passa pela compreensão de quão competitiva é a estrutura daquele setor. Donsimoni et al. (1984, p. 419) explicam que diversos economistas propõem que o desempenho de uma firma em uma indústria é fortemente determinado pela estrutura do mercado na qual opera. Braga e Mascolo (1982, p. 405) argumentam que estruturas industriais não competitivas poderiam tornar possível o exercício do poder de mercado, cujo resultado seria a distorção na alocação dos recursos econômicos. Hart (1983, p. 366) reforça este argumento, afirmando que muitos economistas concordam que a competição tem um importante papel na alocação eficiente dos recursos. Dentro dessa lógica, a estrutura governança corporativa das companhias se enquadraria na "Conduta", sendo a estrutura de mercado uma variável significativa em sua determinação.

As relações acima apresentadas propiciam oportunidades de pesquisas sobre o tema. Como exemplo, diversas pesquisas analíticas e empíricas vêm sendo desenvolvidas recentemente sobre o tema (ALLEN; GALE, 1999; GROSFELD; TRESSEL, 2001; JANUSZEWSKI et al., 2001; RANDOY; JENSSEN, 2004; GUADALUPE; PERÉZ-GONZÁLES, 2006; KARUNA, 2007, 2008; CHOU et al., 2008; GIROUD; MUELLER, 2008, 2009). De forma resumida ${ }^{8}$, essas pesquisas têm investigado variados temas ligados à governança corporativa e que

\footnotetext{
${ }^{8}$ Os estudos estão detalhados no Capítulo 2, especificamente na seção 2.4 .
} 
podem ser influenciados pela competição no mercado de produtos, tais como a(o): i) qualidade da governança corporativa; ii) grau de incentivos oferecidos aos gestores; iii) substituição do CEO; iv) independência do conselho de administração; v) efetividade do conselho de administração; vi) benefícios privados do controle; vii) direito dos acionistas; viii) utilização de cláusulas antitakeover; ix) divulgação de informações; x) política de distribuição de dividendos; xi) efeito do aumento da competição em um setor após sua desregulamentação sobre os mecanismos de governança corporativa adotados pelas companhias; e xii) efeito da interação entre competição e governança corporativa sobre o desempenho operacional e valor da firma.

No Brasil, após ampla revisão de bibliografia efetuada, não obteve-se registros de trabalhos que se propuseram a estudar o impacto da competição no mercado de produtos sobre a estrutura de governança das empresas ${ }^{9}$. Portanto, a crítica feita por Karuna (2008) à utilização de variáveis binárias para considerar os efeitos da indústria sobre a estrutura de governança corporativa também é válida para os estudos desenvolvidos no Brasil, já que em nenhum deles são utilizadas variáveis específicas para caracterizar o grau de competição aos quais as firmas estão submetidas.

Quanto à originalidade, na revisão bibliográfica foram identificados estudos específicos versando sobre o mesmo tema desta pesquisa, ou estudos correlatos, em diversos países, a saber: Alemanha, Canadá, China, Estados Unidos da América, Índia, Polônia, Reino Unido, Suécia e Suíça. Dessa forma, a originalidade da pesquisa não está em estudar um tema inexplorado pela literatura internacional, mas sim em apresentar as primeiras evidências sobre o relacionamento entre competição no mercado de produtos, governança corporativa e desempenho para um país latino-americano.

A viabilidade da pesquisa também é atendida, na medida em que dispõem-se no país de bases de dados públicas e privadas com capacidade de fornecer as principais variáveis objetos do estudo. Ademais, as pesquisas realizadas em outros países asseguram que há testes estatísticos

\footnotetext{
9 Não obstante, trabalhos nacionais estudam a concentração de mercado (aproximação para o nível de competição) com outros objetivos. Machado et al. (2008), Feijó et al. (2001), Braga e Mascolo (1982) são exemplos.
} 
adequados para estudar as relações entre governança, competição no mercado de produtos e desempenho.

Em resumo, diversos estudos realizados no exterior indicam haver impacto significativo da variável competição no mercado de produtos sobre a estrutura de governança corporativa das companhias, bem como haver evidências de que o efeito da governança sobre o desempenho ou valor da companhia depende do grau de competição no mercado de produtos, sem desconsiderar o fato de que os resultados empíricos apresentam pouco consenso sobre o sentido desse relacionamento. Além disso, a literatura, de forma geral, associa essas duas variáveis a um potencial incremento no desempenho e à alocação eficiente de recursos. Somada a estas evidências, tem-se a ausência de estudos específicos sobre o assunto no Brasil. Portanto, justifica-se assim a escolha do tema.

\subsection{Potenciais contribuições}

Primeiramente, em relação ao arcabouço teórico da área, os resultados da pesquisa podem contribuir pioneiramente com a literatura nacional sobre governança corporativa, ao considerar os atributos do mercado no qual a firma opera e os impactos provenientes desses atributos. Internacionalmente, a pesquisa constitui-se em mais uma evidência das relações entre competição, governança corporativa e desempenho, todavia aplicada a outro contexto jurídico e econômico. Assim, poderá servir de comparação para outros estudos.

Do ponto de vista dos pesquisadores da área, a pesquisa contribui com uma nova variável a afetar a definição da estrutura de governança das companhias e, assim, a ser utilizada em modelos estatísticos: a variável "competição". Portanto, novas pesquisas podem incorporar e aperfeiçoar esse desenvolvimento, na medida em que outras métricas podem ser utilizadas para representar o nível de competição de setores.

Por fim, a pesquisa contribui com o debate sobre definições de políticas de governança corporativa, pois ao considerar diversas evidências de que o grau de competição em setores 
tende a influenciar a estrutura de governança corporativa das companhias, os reguladores poderiam estabelecer recomendações de governança de acordo a estrutura de cada setor. 


\section{FUNDAMENTAÇÃO TEÓRICA}

Neste capítulo, são expostos os principais conceitos atinentes ao tema aqui estudado, bem como as relações teóricas e evidências empíricas entre governança corporativa, competição no mercado de produtos e desempenho. Para tanto, dividiu-se o capítulo em quatro seções interdependentes.

A primeira apresenta conceitos fundamentais para o entendimento da temática da governança, incluindo seus alicerces conceituais e mecanismos pelos quais busca atingir os objetivos de alinhamento de interesses ente principais e agentes no contexto corporativo.

Em seguida, expõem-se os conceitos ligados à OI. Em primeiro lugar apresenta-se este campo do conhecimento, para, imediatamente, exporem-se os conceitos relativos ao paradigma ECD, apresentando também suas limitações enquanto arcabouço teórico. Ao final, discute-se a importância da competição no mercado de produtos.

Na seção seguinte, discute-se a relação teórica entre governança e competição por meio da apresentação das idéias de artigos analíticos que tratam do tema.

Por fim, a quarta seção apresenta resultados de diversos trabalhos empíricos sobre o tema, dividindo-se as pesquisas por meio das variáveis estudadas, a fim de identificar os principais problemas estudados e resultados obtidos.

\subsection{Governança corporativa: algumas considerações}

A busca pela maximização da utilidade individual tem o potencial de gerar diferentes incentivos para gestores, acionistas controladores, acionistas minoritários, credores e demais participantes que interagem dentro de uma estrutura abstrata denominada firma. Fama (1980, p. 289) a define como um conjunto de contratos entre diferentes fatores de produção, sendo que cada fator é motivado a satisfazer os seus próprios interesses. No campo de estudos das 
finanças corporativas, é amplamente aceita a visão de que a função-objetivo da firma é assegurar o máximo retorno de longo prazo para os acionistas. No entanto, como os contratos que delegam autoridade entre os diversos participantes não são completos, há potencial para ocorrência de situações envolvendo conflitos de interesses no cumprimento das responsabilidades assumidas por cada um, cuja implicação tende a ser a alocação ineficiente dos recursos da firma.

A delegação de autoridade entre participantes com diferentes objetivos é o cerne do relacionamento agente-principal. As implicações deste relacionamento foram formalmente estudadas por Jensen e Meckling (1976). Os autores definem o relacionamento como “[...] um contrato onde uma ou mais pessoas - o principal - engajam outra pessoa - o agente - para desempenhar alguma tarefa em seu favor, envolvendo a delegação de autoridade para tomada de decisão pelo agente" ${ }^{\prime 10}$. Dessa forma, Hart (1995, p. 678) afirma que na ausência de problemas de agência, os indivíduos atuantes em uma organização teriam a intenção de maximizar o valor da empresa ou minimizar os custos, assim não haveria necessidade de mecanismos de governança corporativa para mitigar problemas advindos da relação agenteprincipal, visto que não existiriam.

Hart (1995, p. 679) argumenta que se todos os contratos fossem estruturados de forma ótima, não haveria espaço para as discussões a respeito do tema governança corporativa, visto que, no entendimento do autor, as estruturas de governança corporativa são úteis na medida em que ações no futuro precisarão ser tomadas sem que tenham sido especificadas em um contrato inicial. Assim, governança corporativa provê um modo de como essas decisões deveriam ser tomadas. Shleifer e Vishny (1997) concordam e afirmam que o problema de agência é resultado da imperfeição dos contratos, já que caso os principais conseguissem definir ex-ante todas as situações possíveis, não haveria o problema de agência, dado que o agente não teria condições de agir de forma discricionária. Em síntese, em função da impossibilidade de prever todas as situações ex-ante, o principal necessita de mecanismos de incentivo e controle que alinhem os interesses do agente aos seus.

\footnotetext{
10 "We define an agency relationship as a contract under which one or more person (the principal (s)) engage another person (the agent) to perform some service on their behalf which involves delegating some decision making authority to the agent".
} 
Governança corporativa insere-se neste contexto, na medida em que tem como objetivo mitigar os problemas advindos dos conflitos de agência entre principal e agente, por meio de um conjunto de mecanismos internos e externos de incentivo e controle. Exemplos de mecanismos internos são o conselho de administração e o próprio estatuto social da firma e exemplos de mecanismo externos são o mercado de controle corporativo, monitoramento dos investidores, iniciativas legais, regulação e um mercado ativo de mão-de-obra (GILLAN, 2006 et al., p. 1). Contudo, não há uma solução geral única para a estruturação de mecanismos de governança, e cada companhia pode ter uma solução ótima para mitigar os problemas advindos dos conflitos de agência.

As discussões e os estudos acadêmicos sobre o tema governança corporativa cresceram exponencialmente nas últimas duas décadas. O tema, no entanto, não é recente. A preocupação em desenvolver mecanismos de incentivo e controle para que os recursos investidos por principais sejam alocados eficientemente pelos agentes, bem como possam retornar aos investidores de direito ao final de um determinado período, data pelo menos do século XVII. Dobija (2008), por exemplo, estuda uma série de mecanismos criados na Companhia das Índias Orientais, precursora das modernas corporações e criada no século XVII. O objetivo destes mecanismos era atenuar o conflito de agência na companhia entre investidores e gestores. Outro exemplo pode ser observado em Chancellor (2001), que descreve uma série de problemas ocorridos com a Companhia dos Mares do Sul, fundada no início do século XVIII. Neste último exemplo, os problemas ocorridos na companhia se deveram a diversos conflitos de interesses exacerbados pela ausência de mecanismos de controle da gestão.

De acordo com Silveira (2004, p. 24), o ativismo de grandes investidores institucionais a partir do final da década de 80 contribuiu para o aumento da importância do tema. Gillan (2006, p. 381) exemplifica a importância do tema no meio acadêmico ao afirmar que uma rápida consulta a bases de dados públicas sobre trabalhos acadêmicos retorna milhares de trabalhos versando sobre o tema governança corporativa. Em relação à sociedade como um todo, Tirole (2006, p. 15) aponta que o aumento da cobertura pela mídia dos assuntos concernentes à governança durante a última década difundiu termos como transparência, fraco ativismo dos conselhos de administração, proteção aos acionistas minoritários, manipulações contábeis, takeovers etc., tornando-os recorrentes até mesmo em discussões domésticas. 
Portanto, cabe a seguinte pergunta: por que governança corporativa tornou-se um tema tão importante? Becht et al. (2002) utilizam-se de seis argumentos para justificar a proeminência do tema: i) a onda de privatizações ocorridas na América-Latina, Europeu Ocidental e Ásia; ii) ativismo dos fundos de pensão; iii) fusões e aquisições na Europa, nas décadas de 80 e 90; iv) desregulamentação e aumento da integração dos mercados; v) as crises ocorridas em alguns países emergentes, tais quais: Brasil, Rússia e alguns países do leste asiático; e vi) os escândalos e falências de corporações americanas. Além dos argumentos expostos por Becht et al. (2002), Silveira (2010) acrescenta a crise financeira de 2008 como um sétimo evento que coopera para o aumento da importância do tema.

Outra justificativa é a sua relação com a idéia de aumento no valor da empresa, conforme exposição realizada por Silveira (2004, p. 25), na qual a empresa, ao adotar melhores práticas de governança, teria uma possível redução em seu custo médio ponderado de capital, resultando em aumento em seu valor. Ademais, estudos, como de Gompers et. al. (2003) e Bebchuk et al. (2004), sistematicamente encontram evidências de que os mecanismos de governança corporativa aumentam o valor da firma para os acionistas. Claessens (2003) estende estes benefícios ao encontrar relação entre boas práticas de governança corporativa e desenvolvimento econômico. Segundo o autor, boas práticas de governança corporativa tendem a aumentar o acesso ao financiamento, diminuir o custo de capital, melhorar o desempenho da firma e melhorar o tratamento aos stakeholders.

Tendo as afirmações acima exposto a proeminência do tema, cabe a apresentação de alguns aspectos-chave de seu arcabouço conceitual, sem a pretensão de apresentar todos os conceitos adjacentes.

\subsubsection{Conceitos fundamentais}

O problema em torno da governança corporativa pode ser abordado a partir de perspectivas diferentes. Em geral, os estudos abordam este tema com base no relacionamento de agência ${ }^{11}$.

\footnotetext{
11 É importante esclarecer que esta abordagem não é única. Exemplo de outra abordagem para o tema governança corporativa pode ser obtida nos trabalhos de Williamson (1984; 1988). Em síntese, o autor expressa que sua abordagem para o tema governança corporativa é baseada nos conceitos da Economia dos Custos de Transação. De qualquer forma, Williamson (1988, p. 568) defende que as abordagens da Teoria da Agência e da Economia dos Custos de Transação são principalmente complementares, visto que ambas colaboram no
} 
O relacionamento de agência foi formalmente definido no trabalho de Jensen e Meckling (1976). A definição dos autores é bastante ampla, podendo ser aplicada em qualquer situação na qual exista delegação de poder de um principal para um agente, não apenas nas relações empresariais. Ainda segundo Jensen e Meckling (1976, p. 5), como ambos, principal e agente, têm motivos para maximizarem sua utilidade pessoal, é razoável pensar que nem sempre o agente agirá em prol dos interesses do principal. Este trabalho teve fundamental importância para o desenvolvimento da linha de pesquisa em governança corporativa, sendo considerado um divisor de águas, conforme análise de Saito e Silveira (2008, p. 79). As principais contribuições oriundas desse trabalho foram: i) criação de uma teoria da firma baseada nos conflitos de interesses individuais, possibilitando realizar predições testáveis empiricamente; ii) definição de um novo conceito de custo de agência; e iii) e a descrição da firma como um nexus de contratos, conforme Saito e Silveira (2008, p. 79).

Ao explorar a natureza do problema de agência, Shleifer e Vishny (1997) afirmam que o problema de agência é resultado da imperfeição dos contratos, pois caso os principais conseguissem definir ex-ante todas as situações possíveis, não haveria o problema de agência, dado que o agente não teria condições de agir de forma discricionária. Em função da impossibilidade de prever todas as situações ex-ante, o principal é obrigado a incorrer em custos para alinhar os interesses dos agentes ao seu, os quais são chamados custos de agência, conforme Jensen e Meckling (1976). Os autores ainda afirmam que os custos de agência surgem em qualquer situação na qual envolva esforço cooperativo entre duas ou mais pessoas. Para Becht et al. (2002, p. 5), o mais básico problema de governança corporativa emerge quando um investidor externo à empresa quer tomar decisões diferentes das tomadas pelo gestor, sendo que tal fato é agravado pela estrutura de propriedade dispersa. Becht et al. (2002, p. 14) reforçam a idéia anterior afirmando que o problema de agência ocorre entre um agente, o diretor-executivo da empresa, e múltiplos principais, tais quais: acionistas, credores, fornecedores, clientes, empregados e outros agentes relacionados com a operação da empresa. O trabalho de Becht et al. (2002) analisa especificamente o estudo de problemas de agência comuns a países com propriedade pulverizada.

entendimento da economia das organizações. Em complemento, Hart (1995, p. 678) argumenta que o problema em torno da governança corporativa não é unicamente explicado pelo problema de agência e expõe que os problemas de governança corporativa emergem em função de problemas de agência e incompletude dos contratos (HART, 1995, p. 688). 
Contudo, os problemas provenientes do relacionamento de agência numa empresa não se restringem aos apresentados acima. Tirole (2006, p. 15) aponta que o problema de agência pode ocorrer tanto entre gestores e acionistas quanto entre acionistas controladores e acionistas minoritários, sendo que o primeiro tipo de problema é comum em países anglosaxões e o segundo é comum em países da Europa Continental. O autor considera como o problema de agência mais comum o ocorrido entre acionistas controladores e acionistas minoritários. Shleifer e Vishny (1997, p. 754) afirmam que, com exceção dos países anglosaxões, no mundo há predominância de alta concentração de propriedade nas empresas. Portanto, o problema de agência potencialmente mais comum seria entre os investidores controladores e minoritários, reforçando a afirmação de Tirole (2006).

Conforme afirmam Kraakman et al. (2004, p. 22), três principais tipos de problemas de agência ocorrem nas empresas. O primeiro tipo, típico de países com estrutura de propriedade pulverizada, ocorre entre os proprietários da firma e os gestores. Nesse caso, os proprietários são os principais e os gestores são os agentes. O segundo tipo ocorre entre acionistas controladores e acionistas minoritários, no qual os minoritários são os principais e os acionistas controladores exercem o papel de agentes. Por fim, o terceiro tipo ocorre entre a empresa como um todo e os diversos agentes que interagem com ela, como empregados, credores e clientes. Com base nas constatações dos autores citados acima, está claro que os problemas de agência variam entre empresas e, por conseguinte, entre países. Como exemplo de problemas de agência, pode-se citar o tunnelling. De acordo com Johnson et al. (2000, p. 1), "Tunneling é definido como a transferência de ativo e lucros para fora da firma, a fim de beneficiar seus acionistas controladores" ${ }^{\prime 2}$. Entendido desta forma, o tunneling é uma forma de expropriar a riqueza dos acionistas minoritários, dado que sua riqueza está sendo transferida para o controlador da firma que ele possui investimentos. Segundo Johnson et al. (2000, p. 3), essa expropriação pode ocorrer de duas formas: i) acionista controlador transfere da firma para seu próprio benefício; ii) acionista controlador aumenta a sua participação no capital da firma, prejudicando os minoritários, sem, no entanto, realizar sua contrapartida. Cabe salientar que, de acordo com Johnson et al. (2000, P. 2), grande parte da atividade de tunnelling é legal, mesmo em países desenvolvidos que adotam o direito codificado.

\footnotetext{
12 "Tunneling is defined as the transfer of assets and profits out of firms for the benefit of their controlling shareholders."
} 
Conforme Shleifer e Vishny (1997), no mundo há diferentes sistemas de governança corporativa, sendo que os principais modelos são o Anglo-Saxão (Estados Unidos e Reino Unido), o modelo Alemão e o modelo Japonês. Estes modelos apresentam diferenças substanciais entre si. Shleifer e Vishny (1997, p. 769) afirmam que o modelo adotado pelos Estados Unidos e Reino Unido baseia-se na proteção legal aos investidores, sendo caracterizado pela baixa concentração de propriedade, exceto em casos temporários de função de aquisições. Dessa forma, para Shleifer e Vishny (1997, p. 750), grande parte das diferenças existente entre os sistemas de governança dos países provêm da natureza legal das obrigações que os gestores têm perante os investidores, juntamente com a forma com que as cortes dos países interpretam e aplicam a lei. No estudo de Becht et al. (2002, p. 21), os estudos apontam três principais razões para a existência de estruturas de propriedade pulverizadas, a saber: i) insuficiência de riqueza por parte dos investidores para adquirir grandes participações nas empresas; ii) diversificação de riscos por parte dos investidores; e iii) a aquisição de grande participação em uma empresa pode dificultar a sua posterior venda no mercado secundário, em função da diminuição de liquidez. Segundo Shleifer e Vishny (1997, p. 769), nos modelos adotados no Japão e na Alemanha a proteção aos investidores é menor, entretanto há substancial presença de grandes investidores, como bancos, financiando os projetos das empresas. Shleifer e Vishny (1997) concluem que o modelo ideal seria um híbrido, combinando características do modelo anglo-saxão, alta proteção aos investidores, com características dos modelos alemão e japonês, presença de grandes investidores.

\subsubsection{Mecanismos internos e externos}

O objetivo primordial dos mecanismos externos e internos de governança corporativa é atenuar o problema de agência, alinhando os interesses do agente aos do principal.

Para Shleifer e Vishny (1997, p. 738), os mecanismos de governança corporativa são as instituições econômicas e legais que podem ser alteradas em função do processo político. Gillan (2006, p. 383) afirma haver ao todo dez mecanismos de governança, sendo cinco internos e cinco externos. Como mecanismos internos, o autor aponta os seguintes: i) Conselho de Administração; ii) incentivos aos gestores; iii) estrutura de capital; iv) cláusulas antitakeover; e v) sistemas de controles internos. Quanto aos mecanismos externos, o autor 
aponta os seguintes: i) leis e regulações; ii) mercado tipo I (mercado de capitais, mercado de controle corporativo e mercado de trabalho); iii) mercado tipo II (basicamente, refere-se a difusão da informação pelo mercado de capitais); iv) mercado tipo III (refere-se principalmente aos serviços técnicos disponíveis nos mercados); e v) vigilância externa, por exemplo a cobertura da mídia.

Um dos mecanismos mais estudados, o Conselho de Administração, segundo Tirole (2006, p. 29), tem como função monitorar o comportamento dos gestores, a fim de que ajam no interesse dos acionistas. Gillan (2006, p. 385) afirma que, em geral, os estudos envolvendo conselho de administração e governança corporativa objetivam encontrar uma relação entre estrutura do conselho e valor da companhia. Com relação aos incentivos aos gestores, Betch et al. (2002, p. 104) concluem que o incentivo dos gestores por meio de remuneração baseada em ações gera efeitos positivos no desempenho da empresa, porém, como as conclusões foram extraídas de estudos no mercado norte-americano, os autores afirmam que o lado negativo é a possível influência dos gestores nas definições de suas remunerações, podendo expropriar os acionistas. Com relação à estrutura de capital, é conveniente traçar-se um paralelo com o trabalho de Jensen (1986), no qual o autor aponta a constituição de dívidas como uma forma de mitigar os custos de agência dos fluxos de caixa livres. Jensen (1986) afirma que a dívida serve como um agente disciplinador do comportamento dos gestores, evitando, dessa forma, que o fluxo de caixa livre seja utilizado discricionariamente. Concernente às cláusulas antitakeover, Gillan (2006, p. 389) afirma que são utilizadas para evitar uma aquisição hostil da empresa.

Com relação ao mecanismo externo "leis e regulação", cabe salientar que Shleifer e Vishny (1997) apontam esse fator como o preponderante para explicar as diferenças existentes entre os modelos de governança corporativa entre países. Kraakman et al. (2004) expõem uma estratégia jurídica a fim de mitigar a vulnerabilidade dos principais em razão do oportunismo dos agentes. A estratégia está baseada em duas subestratégias i) estratégia regulatória e ii) estratégias de governança. Segundo Kraakman et al. (2004, p. 23), as estratégias regulatórias são prescritivas, sendo que a estratégia de governança busca moldar o comportamento do agente de forma indireta. Os mecanismos externos do mercado tipo I também são apontados por Tirole (2006), dos quais podem-se destacar competição no mercado de produtos e mãode-obra. Por fim, vale destacar o papel da mídia como um importante mecanismo externo de 
governança. Dyck e Zingales (2002) afirmam haver um efeito disciplinador da mídia sobre os gestores e acionistas controladores, na medida em que elas os forçam a agirem de maneira aceitável perante os acionistas minoritários, sob risco de desvios serem noticiados.

\subsection{Conceitos de Organização Industrial}

\subsubsection{Organização industrial}

Ao estudar se a competição no mercado de produtos afeta a estrutura de governança corporativa das companhias, implicitamente assume-se que as estruturas de mercado são relevantes para a tomada de decisão. Logo, os conhecimentos provenientes da área de estudos conhecida como OI são úteis para embasar a relação estudada, visto que, de acordo com Fontenele (1995, p.1), a OI destina-se ao estudo da forma como os mercados estão organizados, com o objetivo específico de compreender as formas de concorrência e os potenciais efeitos para a sociedade. De acordo com Tirole (1989), estudos envolvendo OI estão relacionados ao estudo do funcionamento dos mercados, um conceito central nos estudos de microeconomia. Ferguson e Ferguson (1994, p. 1) afirmam que OI é melhor definida como a aplicação da teoria microeconômica para analisar firmas, mercados e indústrias.

Quanto ao objetivo do campo de estudos, Scherer e Ross (1990, p. 2) afirmam que os estudos de OI buscam compreender a forma pela qual: i) o sistema de mercado dirige as atividades dos produtores ao encontro da demanda dos consumidores; ii) os motivos que levam o sistema a falhar; e, iii) o que pode ser feito para ajustá-lo, a fim de tornar o desempenho mais próximo a algum padrão pré-estabelecido.

Fontenele (1995, p. 1) explica que o marco teórico deste campo surgiu no final da década de 30 do século passado, por meio do trabalho do Professor Edward Mason. Segundo Tirole (1989), dois grandes momentos marcaram o desenvolvimento da OI. O primeiro está atrelado aos estudos de Joe Bain e Edward Mason, cuja abordagem era baseada em testes empíricos, com poucos desenvolvimentos de modelos analíticos. O segundo momento iniciou-se por volta de 1970. Ainda segundo Tirole (1989), três fatores determinaram essa segunda onda de 
interesse. O primeiro fator refere-se à crescente insatisfação com as limitações da abordagem empírica para explicar estruturas de mercado com oligopólios. O segundo fator refere-se ao fato de que até aquele momento, poucos economistas teóricos haviam dedicado esforço na formulação de modelos para o campo de estudos, sendo que a partir de 1970 um elevado número de renomados teóricos passou a se interessar pelo desenvolvimento de modelos para a OI. O terceiro fator foi a aplicação do instrumental proveniente da teoria dos jogos nãocooperativos como metodologia dominante nas análises de interação estratégica entre firmas.

Fontenele (1995) coaduna com as idéias apresentadas por Tirole (1989), ao afirmar que os estudos de OI foram construídos, inicialmente, por um caminho alternativo ao da Microeconomia Neoclássica, todavia, valendo-se do instrumental teórico advindo da Teoria dos Jogos, as pesquisas contemporâneas voltaram a ter um grau de abstração bastante elevado quando comparado ao seu estágio inicial. Assim, as pesquisas de OI estão no mainstream das pesquisas em Economia. Outro fato que corrobora a visão de Tirole (1989) é o fato, em geral, os capítulos iniciais dos livros-texto de OI contrapõem os procedimentos metodológicos utilizados pela chamada "Organização Industrial Clássica" com a da "Nova Organização Industrial". As obras de Ferguson (1992), Waldman e Jensen (1998), Carlton e Perloff (2000), Norman e La Manna (1992), Shy (1995), Ferguson e Ferguson (1994) e Davies et al. (1989) servem como exemplo.

Norman e La Manna (1992, p. 2) afirmam que a diferença fundamental entre o paradigma clássico empregado nos estudos de OI e a abordagem contemporânea é a consideração da dimensão estratégica na decisão das companhias. Segundo os autores, as firmas não apenas reagem às condições, mas também tentam levar em consideração as possíveis ações futuras de seus concorrentes. Assim, Norman e La Manna (1992, p. 3) apontam que "A Nova Organização Industrial" utiliza-se de modelos teóricos advindos da Teoria dos Jogos para analisar os problemas provenientes da complexa interação entre agentes econômicos. De acordo com Jacquemin (1987, p. 5), comparado com os estudos iniciais, as pesquisas recentes em OI passaram a incorporar diferentes ferramentas microeconômicas, como modelos de competição imperfeita e noções de Teoria dos Jogos, aumentando dessa forma o número de soluções para situações intermediárias entre competição perfeita e monopólio. Uma implicação imediata da aplicação desse novo ferramental às pesquisas sobre OI é dificuldade na realização de testes empíricos (NORMAN; LA MANNA, 1992, p. 4) 
Em complemento, Waldman e Jensen (1998, p. 5) afirmam ser possível utilizar duas abordagens para estudar a OI. A primeira refere-se ao chamado paradigma ECD, que foi a primeira abordagem empírica desse ramo do conhecimento. A segunda é chamada de abordagem da "Escola de Chicago". Economistas adeptos dessa opção metodológica contestam os resultados dos estudos que utilizaram o paradigma ECD como arcabouço teórico e propõem outras formas de analisar os problemas desse campo de estudo. Fontenele (1995) cita que a partir da década de 70, passou a ser posto em cheque os achados dos estudos baseados no paradigma ECD, principalmente por três principais "novas escolas" da OI: i) Teoria das Estruturas Eficientes; ii) Teoria dos Mercados Contestáveis; e iii) Teoria dos Jogos aplicada ao estudo dos Oligopólios.

Os conceitos apresentados ensejam que o campo de estudos da OI visa compreender a dinâmica dos mercados ou indústrias nos quais as firmas atuam, com o intuito de estudar as implicações dessa dinâmica sobre as decisões das companhias e os impactos disso para a sociedade como um todo. Não obstante o desenvolvimento de diversos estudos teóricos sobre o tema, vale ressaltar o caráter prático deste campo de estudo. Exemplo disto pode ser observado no Guia para Análise Econômica de Atos de Concentração Horizontal, aprovado em conjunto pela Secretária de Acompanhamento Econômico (SEAE) e Secretária de Direito Econômico (SDE), em 2001, cujo conteúdo possui diversos conceitos advindos das teorias de OI.

Em síntese, estudos que utilizam conceitos advindos da OI podem recorrer a diferentes opções metodológicas dentro dessa área de pesquisa. Na pesquisa, será utilizado o arcabouço teórico do chamado paradigma ECD, cujos principais conceitos são apresentados na seção ulterior, bem como as críticas feitas a tal abordagem. Tentar-se-á demonstrar que mesmo com diversas críticas, o paradigma é útil para o estabelecimento de potenciais relações entre variáveis em trabalhos empíricos. 


\subsubsection{Estrutura-conduta-desempenho}

O paradigma da ECD foi desenvolvido pelos Professores Edward Mason e Joe S. Bain, que se basearam na teoria neoclássica da firma, essencialmente nos modelos de competição perfeita, monopólio, concorrência monopolista e diversos modelos de oligopólio (FERGUSON, 1992). A abordagem tradicional da ECD para estudos empíricos em OI foi uma revolucionária mudança quando o Professor Edward Mason a introduziu (CARLTON; PERLOFF, 2000). A intuição primordial desta abordagem é que as diferenças observadas nas estruturas dos mercados levam a diferentes condutas e desempenhos das firmas (CUBBIN, 1988).

A Figura 1 abaixo ilustra a lógica desse paradigma:

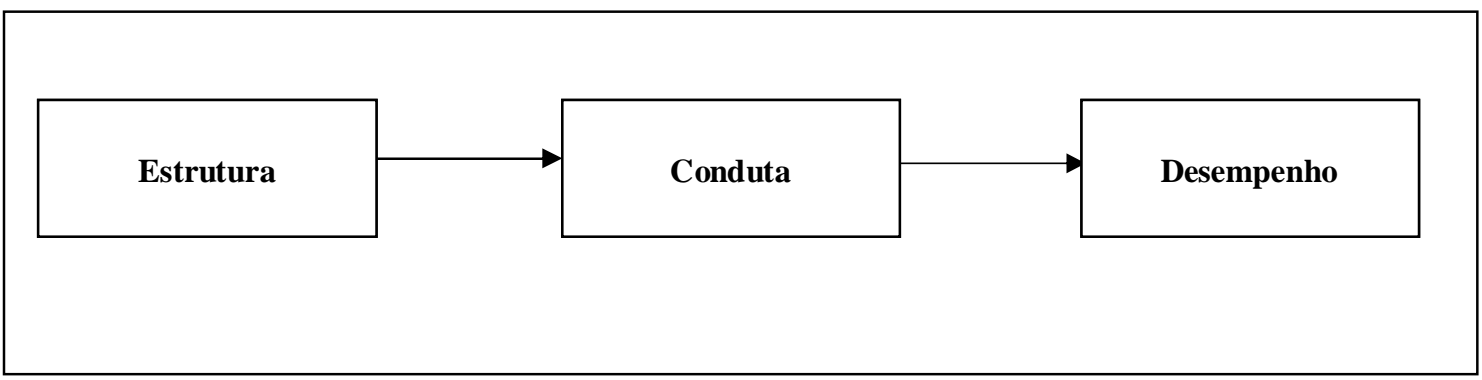

Figura 1: Abordagem tradicional do paradigma ECD

FONTE: adaptado de FERGUSON; FERGUSON, 1994, p. 16.

Ferguson (1992, p. 7-8) e Ferguson e Ferguson (1994, p. 14-15) explicam o significado dos substantivos "Estrutura" e "Conduta", no contexto da abordagem ECD:

i) Estrutura: refere-se às características e composição do mercado e indústria em uma economia, podendo ser caracterizada por meio do número e/ou distribuição de clientes e fornecedores, extensão pelas quais os produtos são diferenciados, presença ou ausência de barreiras à entrada no mercado e à extensão da integração ou diversificação das firmas.

ii) Conduta: refere-se ao comportamento da firma em um mercado, as decisões tomadas e aos modos pelos quais essa decisão é tomada, por exemplo a decisão de realizar propaganda e fazer investimento em pesquisas estão dentro da idéia de conduta.

Em relação ao "Desempenho", Ferguson (1992, p. 8) afirma ser a preocupação fundamental, cuja questão essencial é identificar se a firma aumentou a riqueza econômica geral da sociedade, podendo ser medido pelas relações entre preço e custo ou pelo nível de lucros auferidos pela firma. 
O Quadro 1, abaixo, contrasta a estrutura de dois diferentes mercados. O mercado 1 apresenta características de um mercado sob condição de concorrência perfeita. Assim, pelo paradigma ECD poderiam ser feitas deduções por meio da análise da comparação entre mercado 1 e 2.

\begin{tabular}{lll}
\multicolumn{2}{c}{ Quadro 1 - Comparação da estrutura de dois mercado hipotéticos } \\
\hline Características estruturais & Mercado 1 & Mercado 2 \\
\hline Número de firmas & $\begin{array}{l}\text { Muitas firmas com poucas } \\
\text { participação cada uma }\end{array}$ & $\begin{array}{l}\text { Quatro firmas com } \\
\text { participações de mercado } \\
\text { parecidas } \\
\text { Poucos }\end{array}$ \\
Compradores & Muitos & Diferenciado \\
Natureza do produto & Homogêneo & Substanciais \\
\hline
\end{tabular}

FONTE: adaptado FERGUSON; FERGUSON, 1994, P. 17.

A partir da década de 50, as proposições da abordagem ECD passaram a ocupar o posto de paradigma teórico por excelência das teorias microeconômicas auto-rotuladas como verdadeiramente preocupadas com as questões práticas ligadas às empresas, às indústrias e aos mercados. (KUPFER, 1992), sendo a corrente teórica predominante nos estudos de OI até a década de 70 (FONTENELE, 1995).

Do exposto, extrai-se que ao afirmar haver causalidade entre a forma como um mercado está estruturado e a conduta e desempenho da companhia, implicitamente assume-se que a estrutura de mercado é uma variável exógena, sendo este um dos pontos de grande parte das críticas sofridas pela abordagem ECD. As críticas sugerem que o relacionamento entre estrutura, conduta e desempenho seja bem mais complexo do que o originalmente assumido, havendo a simultaneidade na determinação das variáveis que constituem a estrutura de mercado, conduta e desempenho (KUPFER, 1992; FERGUSON, 1992; CARLTON; PERFLOFF, 2000; BAKER; BRESNAHAN, 2006). Essa vulnerabilidade na abordagem ECD desencadeou a busca por outras opções metodológicas a partir da década de 70, conforme exposta na seção precedente.

Por exemplo, Demsetz (1973) afirma que a concentração de determinados mercados pode ocorrer em função de as firmas restantes serem as que possuem maior habilidade em relação às demais, sendo as que geram maiores benefícios à sociedade. Portanto, nesse caso, o desempenho da firma determinaria o grau de concentração daquele setor, ou seja, a 
concentração da firma seria uma variável exógena, dependente do desempenho das firmas daquele setor. Donsimoni (1984) et al. também estudam as implicações das abordagens utilizadas para o estudo do poder de mercado das firmas. Em síntese, os autores concluem que a principal diferença entre a visão estruturalista, baseada na abordagem da ECD, e as novas abordagens para aferição do poder de mercado está na adoção da premissa sobre o que é exógeno. Essa premissa tem enormes impactos nos objetivos e métodos da investigação empírica e, por conseguinte, no tipo de recomendação de política de regulamentação a ser feita. Norman e La Manna (1992) criticam justamente o aspecto de na abordagem ECD não ser possível claramente definir quais são os fatores exógenos e quais são endógenos. Ferguson e Ferguson (1994) complementam e citam que a relação entre estrutura, conduta e desempenho é bem mais complexa. Jacquemin (1987) também crítica o fato de nessa abordagem o papel dos agentes ser minimizado, na medida em que assume-se que as firmas têm o mesmo objetivo e adaptam-se passivamente ao ambiente no qual estão inseridas ${ }^{13}$.

A Figura 2 representa, até certo ponto, as principais críticas feitas pelos autores citados:

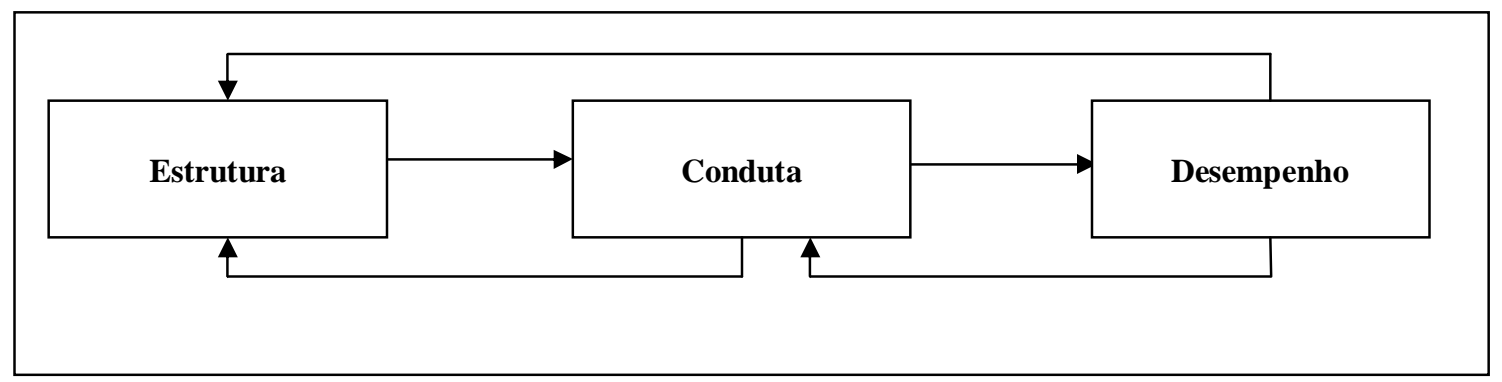

Figura 2: Relacionamento complexo entre estrutura, conduta e desempenho FONTE: Adaptado de FERGUSON; FERGUSON, 1994, p. 18.

Não obstante as críticas, Gerosky (1989) expõe que em ambas as frentes, programa de pesquisa e um guia para as ações políticas, o paradigma da ECD teve êxito, tendo em vista os seguintes aspectos: i) forneceu um ferramental estruturado de idéias e conceitos; ii) gerou um volume grandioso de resultados empíricos que sugerem haver relacionamento entre a estrutura de mercado do desempenho no mercado; e iii) levou os formuladores de política a se

\footnotetext{
${ }^{13}$ Como exemplo, no Brasil Machado et al. (2008) estudam se o desempenho da indústria de laticínios determinou a concentração. Os autores concluem haver endogeneidade entre as variáveis de concentração e desempenho. Esse resultado corrobora as críticas expostas sobre a possível endogeneidade entre as principais variáveis do paradigma ECD.
} 
preocuparem com o nível e o aumento na concentração industrial na definição de seus objetivos políticos. Portanto, estudos que utilizem as idéias advindas desse paradigma podem ainda resultar em importantes contribuições para diversos campos do conhecimento. Norman e La Manna (1992, p. 1), sem desconsiderar as críticas, citam que não há dúvidas sobre a utilidade da análise por meio do paradigma ECD, pois por meio da condução correta de uma pesquisa é possível extrair diversas perspectivas interessantes sobre relações entre variáveis, contudo sem afirmar haver relação de causalidade.

Logo, para os objetivos da pesquisa, a estrutura de governança corporativa será abarcada dentro da "Conduta" da companhia. O estabelecimento desta relação é coerente com a abordagem da ECD apresentada, visto que as diferentes configurações das estruturas de mercado, especificamente neste caso o grau de competição no mercado de produtos, tendem a influenciar as formas pelas quais as companhias estruturam seus sistemas de governança corporativa.

\subsubsection{Competição no mercado de produtos}

Como já esclarecido na seção 1.1, na pesquisa é estudada, especificamente, a competição no mercado de produtos e a definição proposta por Karuna (2008, p. 2) é utilizada como referência: “[...] o nível de esforço exigido das firmas para ganhar negócios de seus concorrentes na indústria." Em seguida, são apresentadas mais algumas discussões sobre competição, a fim de enquadrá-la aos objetivos da pesquisa.

Tomados em conjunto, os trabalhos de Alchian (1950), Stigler (1958) e Fama (1980) permitem afirmar que um alto nível de competição no mercado de produtos é mais danoso para companhias que são geridas ineficientemente. A intuição para essa conclusão é que mercados mais competitivos tendem a exercer maior pressão sobre as companhias, forçando a saída das ineficientes.

De acordo com Nickell (1996, p. 724), o senso comum indica que competição é algo benéfico. Segundo o autor, crê-se que competição exerce pressão sobre os custos, reduz o relaxamento organizacional, provê incentivos para a organização eficiente da produção, além 
de direcionar a inovação. Essa crença possui diversas implicações, principalmente para as políticas de defesa da concorrência. Entretanto, o autor afirma que essa crença geral não é suportada por nenhum fundamento teórico unânime ou por um extenso corpo de trabalhos empíricos. Nickell et al. (1997) estudam três fatores que contribuem com o aumento da produtividade da firmas. Competição no mercado de produtos, pressão exercida pelo mercado financeiro e controle acionário foram os fatores estudos pelos autores. No estudo, Nickell et al. (1997) concluem que os três fatores contribuem com o incremento da produtividade nas firmas do Reino Unido, contudo a competição no mercado de produtos serve como substituta à pressão exercida pelo mercado financeiro e pelo controle acionário.

Apresentados acima os conceitos atinentes à competição, a seguinte pergunta é válida: qual a relação entre a abordagem ECD e competição no mercado de produtos? Na seção precedente, foram apresentados conceitos relacionados à abordagem da ECD e foi estabelecido que a essência desta abordagem é a influência da estrutura de um mercado sobre a conduta e, por conseguinte, desempenho da firma. Besanko et al. (2006, p. 214) afirmam que os mercados, em geral, são descritos como sendo concentrados ou não-concentrados. Os autores prosseguem com a argumentação e afirmam que essa caracterização costuma permitir uma avaliação simples e até certo ponto precisa da provável natureza da concorrência num mercado, sendo essa caracterização ajudada pela existência de medidas de estrutura de mercado, que se referem ao número e à distribuição de firmas num mercado.

$\mathrm{Na}$ abordagem ECD, a caracterização do nível de competição de um mercado costumeiramente é feita por meio de um ou mais índices de concentração (BOONE et al., 2007). Curry e George (1983, p. 203) afirmam que a concentração, usualmente, é considerada uma significante dimensão da estrutura de mercado porque desempenha um importante papel na definição de poder de mercado e, por conseqüência, no desempenho e comportamento dos negócios. Shy (1995, p. 2) complementa ao expor que concentração é um dos principais assuntos dentro dos estudos de OI. Segundo Ferguson e Ferguson (1994, p. 39), a implementação da abordagem ECD necessita da identificação das estruturas de mercado, assim métricas de concentração de mercado têm sido utilizadas com esse objetivo. Davies et al. (1989, p. 74) explicam que um mercado altamente concentrado é dominado por um pequeno número de grandes vendedores e, do ponto de vista teórico, afirmam que a 
identificação de métricas de concentração de mercado adequadas pode representar, empiricamente, o grau de oligopólio de um setor.

De acordo com Braga e Mascolo (1982), concentração significa o acúmulo de certos atributos econômicos por correspondentes unidades de controle e tem se revelado um conceito extremamente útil em vários campos de investigação econômica, tais como distribuição de renda e estrutura industrial. Para os autores, deve-se esperar que a probabilidade de uma conduta típica de monopólio seja determinada pelo grau de concentração da indústria. Assim, o interesse sobre a concentração industrial, do ponto de vista econômico, é que ela torna possível o exercício do poder de monopólio ou, mais genericamente, do poder de mercado, em estruturas industriais não-competitivas. Para Baker e Bresnahan (1992), a identificação de um potencial exercício de poder de mercado por parte de uma companhia é útil para coibir possíveis ameaças à concorrência.

Em síntese, os índices de concentração costumeiramente empregados nos estudos que valemse da abordagem da ECD têm o intuito de identificar um possível exercício de poder de mercado por parte de uma companhia e, assim, tentar captar a competição no mercado de produtos Logo, quanto mais concentrado for um mercado ou indústria, maior será a probabilidade do exercício do poder de mercado e, por conseguinte, menor será o nível de competição esperado.

\subsection{Argumentos teóricos das relações entre as variáveis}

Nas duas seções precedentes, foram apresentados alguns conceitos úteis para a consecução desta pesquisa, tanto do campo de estudos da governança corporativa quanto da OI, com ênfase nos conceitos da abordagem ECD. Por conseguinte, o objetivo específico desta seção é apresentar a inter-relação entre competição no mercado de produtos e governança corporativa, tendo como parâmetro o objetivo da pesquisa. Dessa forma, são apresentados alguns trabalhos teóricos que buscaram estabelecer relações entre competição no mercado de produtos, pressão sobre os gestores e governança corporativa. Além da parte teórica, alguns desses estudos 
também realizaram testes empíricos com base na predição dos modelos analíticos, cujos resultados constam da seção 2.4 .

Para Hart (1983, p.366), a competição desempenha o papel de disciplinadora. O autor a considera como um mecanismo indutor de comportamento dentro das companhias, principalmente no sentido de reduzir o desleixo gerencial. A idéia central do artigo de Hart (1983) é desenvolver um modelo que relacione competição e desleixo gerencial, com o intuito de demonstrar que a presença de competição no mercado de produtos tende a diminuir o relaxamento gerencial. No modelo de Hart (1983), a ineficiência é resultado de duas condições: i) conflito de interesses entre proprietários e gestores; e ii) impossibilidade de monitorar totalmente as ações dos gestores por parte dos proprietários. O modelo considera a existência de dois tipos de firma: empreendedora e gerencial. Firmas empreendedoras são assumidas como dirigidas no interesse de seus proprietários e, assim, buscam a maximização do resultado. Firmas gerenciais, ao contrário, são destinadas a atender os gestores que tenham metas próprias. Os proprietários não podem observar diretamente os esforços dos gestores. No entanto, podem observar os resultados de seus esforços. Para encorajar os gestores a aplicarem um apropriado nível de esforço, os proprietários têm a opção de elaborar um sistema de incentivo. Além disso, os proprietários não conhecem com precisão os custos da sua empresa. Portanto, não é possível identificar se o mau desempenho observado é função de condições próprias da firma ou de relaxamento da gestão. Como resultado, sempre haverá relaxamento gerencial mesmo com a escolha de esquemas de incentivo apropriados. Assim, quando os custos forem baixos, os gestores poderão agir discricionariamente e continuariam a cumprir sua meta de resultado.

Hart (1983) demonstra que, sob essas condições, a competição no mercado de produtos pode reduzir o desleixo gerencial. A intuição do modelo é a seguinte: suponha que haja um componente comum ao custo de todas as firmas, portanto quando o custo de uma firma for baixo, o das outras firmas também será. Além disso, suponha que os custos total e marginal são positivamente correlacionados. Assim, quando os custos diminuírem, haverá expansão das firmas empreendedoras e, por conseguinte, aumentará o número de fornecedores no mercado de produtos e os preços tenderão a cair. Como resultado, os gestores que necessitam cumprir metas de lucro terão menos oportunidades para engajarem no desleixo gerencial. $\mathrm{O}$ fato é: se apenas o custo de uma determinada firma caísse, os gestores poderiam se beneficiar 
desta queda e absorveriam esse ganho na forma de maior desleixo. No entanto, como há diversas outras firmas no mercado, os gestores poderão capturar apenas uma parte da redução em forma de relaxamento. Assim, a quantidade média de relaxamento gerencial será reduzida comparativamente a uma situação em que os custos da firma são independentes, pois há mais firmas no mercado e, portanto, será possível comparar os resultados. Em síntese, no modelo de Hart (1983) a competição possibilita a comparação de desempenho entre companhias e, essencialmente, diminui o poder discricionário dos gestores, cooperando para o alinhamento de interesses entre principal e agente.

No entanto, Scharfstein (1988) discorda do modelo especificado por Hart (1983). Os resultados de seu modelo apontam que competição pode exacerbar os problemas de incentivo dos gestores. O efeito positivo ou negativo da competição no mercado de produtos dependerá, fundamentalmente, das preferências dos gestores. A ambigüidade do resultado, afirma Scharfstein (1988), sugere que se competição mitiga problemas de incentivo, não está clara a completa caracterização de como isto ocorre. Portanto, os resultados implicam que não há concordância quanto ao preciso mecanismo por meio do qual competição afeta incentivos. $\mathrm{O}$ autor afirma ter poucas evidências da natureza do conflito entre acionistas e gestores, portanto torna-se dificultosa a tarefa de afirmar com confiança sobre a interação entre competição no mercado de produtos e incentivos dos gestores.

Nalebuff e Stiglitz (1983) estudam a importância desempenhada pela competição no delineamento de esquemas de remuneração baseados do desempenho relativo dos gestores e trabalhadores da firma. Segundo os autores, tais sistemas tornam-se desejáveis quando três condições são satisfeitas: i) o esforço dos gestores não pode ser observado diretamente; ii) a relação entre saída e a entrada de firmas é estocástica, ou seja, de modo que observando-se a entrada não é possível inferir sobre como foi a saída. ; iii) os distúrbios estocásticos que afetam a relação entre entradas e saídas de diferentes firmas devem ser correlacionados. Esquemas de remuneração baseados em desempenho relativos são preferíveis em função de, em condições normais, se ajustarem às condições do mercado. No entanto, caso o mercado não seja competitivo, não haveria forma de comparar o desempenho dos gestores e empregados. Tal idéia é de certa forma similar à desenvolvida no trabalho de Hart (1983), no qual havia a necessidade da presença de outras companhias no mercado para a comparação de custos entre elas. Portanto, a competição no mercado de produtos estaria cooperando com o 
delineamento de esquemas de remuneração considerados adequados no alinhamento de interesses entre proprietários, gestores e empregados.

Os três trabalhos apresentados acima têm como objetivo principal, em essência, demonstrar como a competição no mercado de produtos pode ajudar o principal a observar as ações dos agentes e, assim, tomar medidas corretivas, em casos necessários. Para Hermalin (1992), essa visão é bastante limitada. Segundo o autor, outros efeitos da competição podem ser abordados, tais quais: Qual a relação entre esses efeitos? Como eles se relacionam com o efeito da mudança de informação? Em síntese, o modelo analítico desenvolvido pelo autor decompõe os efeitos da competição sobre o comportamento do executivo em quatro possíveis efeitos: ajuste no risco, renda, estrutura de informação e valor relativo das ações dos gestores. Os quatro efeitos possuem relação ambígua sobre o comportamento dos executivos. Isso indica a ausência de concordância teórica entre o nível de competição e o comportamento dos executivos. No entanto, segundo Hermalin (1992), seu trabalho estabelece condições suficientes para analisar sob quais circunstâncias um aumento no nível de competição levará o executivo a adotar o comportamento comumente teorizado, que é o aumento em seu esforço. Segundo Hermalin (1992), o estudo expande os achados de Scharfstein (1988) em duas formas: i) além do problema de indisponibilidade de informações, o estudo de Hermalin (1992) também considera a impossibilidade de observar as ações dos gestores; e ii) identifica mais claramente a importância do efeito-renda e delineia o papel da renda frente a outros efeitos.

Outro trabalho que visa a estudar o impacto da competição sobre o comportamento dos gestores é o de Schimidt (1997), no entanto o principal mecanismo disciplinador nesse caso é a possibilidade de liquidação da firma. Em tal estudo, o autor conclui que o aumento da competição no mercado de produtos aumenta a probabilidade de firmas conduzidas com certo desleixo pelos gerentes serem liquidadas. A conseqüência básica de um aumento na competição é a redução dos lucros. Assim, os dois efeitos sobre os incentivos dos gestores provenientes do modelo são os seguintes: i) se uma firma possui altos custos, então a redução dos lucros tem o potencial de torná-la não viável, por conseguinte aumenta a probabilidade de que a firma torne-se insolvente; isto induz o gestor a trabalhar mais para reduzir o custo e impedir a liquidação da companhia, com o intuito de evitar a perda de seu emprego; ii) como um aumento na competição reduz os lucros, também pode afetar os benefícios de induzir a 
altos níveis de esforços. Nesse caso, o efeito é ambíguo: se o benefício de uma redução de custo diminui com o aumento da competição, o proprietário da firma estará menos disposto a pagar um alto rendimento aos gestores pelo aumento no esforço. Portanto, o esforço do gestor diminuiria em função de um aumento da competição.

Outros importantes achados das pesquisas que envolvem o efeito da competição no mercado de produtos sobre os gestores provêm do estudo de Raith (2003). Neste estudo, discutem-se duas questões ainda não resolvidas, segundo o autor: i) a primeira é como os incentivos dos gestores estão relacionados com a competição no mercado de produtos; ii) a segunda refere-se como os incentivos estão relacionados com o risco. Dados os objetivos desta dissertação, serão apresentados os achados da primeira questão. Apesar das contribuições de Stiglitz e Nalebuff (1983), Hart (1983), Scharfstein (1988), Hermalin (1992) e Schimidt (1997), não há nenhuma conclusão única sobre a forma pela qual a competição no mercado de produtos afeta o incentivo dos gestores. Raith (2003) tenta elucidar o tema por meio de um modelo que estuda como os incentivos dos gestores são afetados, em uma indústria oligopolista, pela competição no mercado de produtos. O resultado do trabalho de Raith (2003) é que com o aumento da competição devido à presença de bens substitutos e aumento do tamanho do mercado, firmas oferecem altos incentivos aos seus executivos para incentivá-los a reduzir custos, mesmo com o aumento da volatilidade dos lucros.

De acordo com Ruzzier (2009), a idéia de que competição induz a tomada de melhores decisões raramente é sujeita a análises formais. A fim de formalizar essa idéia, Ruzzier (2009) elabora um modelo no qual as mudanças da competição no mercado de produtos afetam o grau de autonomia dos gestores. De acordo com o autor, a crença geral é de que o aumento da competição induziria os gestores a tomarem melhores decisões. No entanto, Ruzzier (2009) conclui seu trabalho de forma contrária. A principal contribuição de seu trabalho é desafiar a visão comum, ao demonstrar que a ameaça da competição pode também reduzir a congruência de interesses. De certa forma, o trabalho de Schimidt (1997) discute a ambigüidade do efeito da competição sobre o comportamento dos gestores.

Beiner et al. (2009) também modelam a relação entre competição no mercado de produtos e incentivos gerenciais. Os autores utilizam uma relação agente-principal em um oligopólio operando sob o modelo de Cournot. As predições do modelo são basicamente três: i) a relação 
entre a efetividade do esquema de incentivo e a intensidade da competição depende do nível absoluto de competição, pois para baixos níveis de competição, mais competição leva a baixos incentivos e para altos níveis de competição, um aumento de competição resulta em grandes incentivos; ii) o efeito marginal da competição sobre a efetividade do esquema de incentivo aumenta com o nível de competição; iii) o efeito da competição sobre o valor da firma é negativo, significando que firmas em ambientes mais competitivos têm menores expectativas de lucros. Outras contribuições dos autores são que o modelo desenvolvido prevê uma relação ambígua entre competição no mercado de produtos e incentivos, dependendo fundamentalmente da intensidade da competição. Além disso, prevê relação não-linear entre as variáveis. Resultados teóricos, de certa forma, semelhantes aos de Schimidt (1997) e Ruzzier (2009).

Não obstante a contribuição dos estudos apresentados, a relação entre governança corporativa e competição no mercado produtos é tratada de forma indireta, sempre por meio da influência da competição sobre os gestores da firma. Nesse sentido, o trabalho de Allen e Gale (1999) apresenta mais claramente a relação entre estas variáveis. A posição teórica dos autores é de que a competição no mercado de produtos é substituta às boas práticas de governança corporativa. Os autores investigam cinco mecanismos costumeiramente estudados na literatura de governança, a saber: i) conselho de administração; ii) remuneração dos executivos; iii) mercado de controle corporativo; iv) concentração de propriedade e monitoramento por instituições financeiras; e v) dívidas. Os autores concluem que a configuração de cada mecanismo varia muito de país para e país, mas, mesmo assim, companhias com práticas de governança corporativa consideradas piores obtêm um desempenho operacional superior às demais. Para os autores, os trabalhos de Hart (1983), Nalebuff e Stiglitz (1983), Scharfstein (1988) e Schimidt (1997) são limitados em diversos aspecto: i) analisam o papel da competição sobre os gestores apenas pela perspectiva do relacionamento de agência; ii) focam apenas em modelos de minimização de custos; iii) responsabilizam unicamente a falta de esforço de gerentes como a causa para a não maximização do valor da firma ; iv) modelos não explicam o que levaria as empresas a buscarem um desempenho superior caso fossem todas firmas "gerenciais"; v) modelos assumem competição perfeita, no entanto essa não é a situação mais comum observada no mercado, sendo que não está claro o papel da competição em mercados imperfeitos. Os autores concluem que outras abordagens, mais do que o relacionamento de agência, devem ser 
empregadas para entender as diferenças de desempenho entre firmas com práticas dispares de governança corporativa. $\mathrm{O}$ aspecto determinante para os autores é a dinâmica do processo competitivo, pois para sobreviverem em ambientes competitivos constantemente em mutação, as firmas devem possuir times de gestores que façam mais do que minimizar custos.

Por fim, cabe citar o trabalho de Fulghieri e Suominen (2005) por analisar a relação ente competição no mercado de produtos e governança corporativa de maneira distinta dos estudos apresentados. Basicamente, os autores visam a responder o seguinte questionamento: Qual o impacto da qualidade de governança corporativa médio de uma economia sobre grau de concentração observado na indústria? O argumento central dos autores é que quanto maior for a qualidade do sistema de governança corporativa, maior será o nível de competição, portanto menor grau de concentração da indústria. Dessa forma, a causalidade entre qualidade de governança corporativa em uma economia e o grau de competição pode de fato ser de forma oposta à prevista na literatura. Os autores mostram que economias caracterizadas por melhores sistemas de governança corporativa são também caracterizadas pela presença de baixa concentração industrial, baixo endividamento em relação ao patrimônio, propriedade menos concentrada e baixos retornos sobre ativos.

Os trabalhos apresentados acima estabelecem a relação teórica entre competição no mercado de produtos, governança corporativa e desempenho, cuja implicação é a possibilidade da realização de estudos empíricos. Ademais, levando-se em consideração que grande parte dos estudos empíricos desenvolvidos na área de governança corporativa tende a observar seu impacto sobre o desempenho da firma, as relações ora apresentadas também são úteis para tais trabalhos, pois demonstram que a competição pode ser um importante determinante na definição da estrutura de governança corporativa. No entanto, as predições dos modelos analíticos variam consideravelmente, desde a abordagem conceitual empregada até a causalidade entre as variáveis. Assim, os trabalhos empíricos desenvolvidos sobre a relação entre competição, governança e desempenho, objetos da próxima seção, podem contribuir para o entendimento do sentido do relacionamento entre elas. 


\section{$2.4 \quad$ Evidências empíricas}

Conforme Ali et al. (2008), estudos que investigam a relevância da variável competição no mercado de produtos sobre diversas variáveis financeiras e econômicas é crescente. $\mathrm{O}$ interesse no tema deve-se à crença geral de que a competição tende a disciplinar o comportamento dos agentes internos da firma (HART, 1983). Portanto, torna-se relevante considerá-la nos estudos empíricos de áreas como contabilidade, economia e finanças, em razão de diversas relações entre variáveis recorrentemente testadas nessas áreas poderem se beneficiar das implicações da competição no mercado de produtos sobre as variáveis estudadas.

Com o intuito de tornar a apresentação dos trabalhos pesquisados organizada, onze categorias foram criadas para classificá-los, a saber: i) qualidade da governança corporativa; ii) grau de incentivos oferecidos aos gestores; iii) substituição do CEO; iv) conselho de administração; v) benefícios privados do controle; vi) utilização de cláusulas antitakeover; vii) divulgação de informações; viii) política de distribuição de dividendos; ix) efeito do aumento da competição em um setor após sua desregulamentação sobre os mecanismos de governança corporativa adotados pelas companhias; $x$ ) efeito da interação entre competição e governança corporativa sobre o valor da firma e xi) efeito da interação entre competição e governança corporativa sobre o desempenho da firma.

Portanto, nas próximas subseções passa-se a apresentação dos trabalhos pesquisados. $\mathrm{Na}$ última subseção, 2.4.12, é apresentado um amplo quadro com o resumo dos principais aspectos dos trabalhos, a fim de tornar a consulta por parte de pesquisadores interessados no tema mais simples. 


\subsubsection{Qualidade da governança corporativa}

Competição no mercado de produtos afeta a qualidade de governança corporativa das companhias? Chou et al. (2008) e Karuna (2008) estudam essa relação e chegam a resultados diferentes.

Chou et al. (2008) estudam o impacto da competição no mercado de produtos sobre a qualidade de governança corporativa das firmas. O período de 1990 a 2005 é utilizado no estudo. Apenas empresas americanas com negociação em bolsas de balores fazem parte do trabalho. Como aproximação de qualidade de governança corporativa, os autores utilizam os índices desenvolvidos por Gompers et al. (2003) e Bebchuk et al. (2004). Com relação à métrica para competição no mercado de produtos, os autores utilizam o Índice de HerfindahlHirschman (HHI) e uma medida denominada Industry Adjusted Price-Cost Margin (IPCM). As principais conclusões do estudo vão ao encontro das predições de Allen e Gale (1999), pois competição apresentou-se nos resultados como uma variável substituta da governança corporativa. Firmas em mercados com alta competição tendem a ter "fraca" governança corporativa. Firmas com baixo "poder de mercado" tendem a ter práticas pobres de governança. Tomadas em conjunto, as análises ao nível da indústria e ao nível da firma permitem inferir, pelo menos no trabalho dos autores, que governança corporativa torna-se menos importante à medida que a competição aumenta. Como previsto na literatura, há um efeito disciplinador da competição sobre os gestores. Por fim, os autores demonstram que a qualidade de governança corporativa tem um efeito significativo no desempenho da companhia apenas quando a competição é baixa, em linha com os achados de Giroud e Mueller (2008). Em síntese, os autores encontram não haver incremento de valor advindo de melhores práticas de governança em companhia inseridas em mercados no qual a competição é muito intensa. Segundo os autores, a maior implicação dos resultados é que o problema de agência em empresas submetidas à intensa competição pode ser menos severo do que prevê a literatura.

Karuna (2008) estuda o efeito da competição no mercado de produtos sobre três mecanismos internos de governança corporativa. O período de 1992-2003 é utilizado no estudo. Três diferentes amostras de empresas norte-americanas fazem parte do trabalho, em função dos testes estatísticos utilizados e a disponibilidade de dados: i) 1206 companhias; ii) 1174 
companhias; e iii) 971 companhias. Como proxy de competição, o autor emprega a mesma abordagem utilizada por Karuna (2007), a saber: existência de produtos substitutos; tamanho do mercado e custos de entrada. Como proxy de governança corporativa são utilizados o tamanho e independência do conselho de administração das companhias e a extensão dos direitos dos acionistas, medida pelo "G-index". Além disso, o autor também realiza testes empíricos com um índice formado pelos três mecanismos em conjunto. A pesquisa apresenta importantes resultados. Em suma, encontra que firmas em mercados mais competitivos geralmente têm menores conselhos, mais diretores externos, maior proteção aos acionistas e maior índice geral de governança. Em um teste adicional, encontrou-se evidência de que competição tem uma relação positiva com a probabilidade de os cargos de diretor-presidente e presidente do conselho de administração serem ocupados por pessoas distintas. Outro resultado importante foi o fato de um dos testes econométricos ter apontado uma relação quadrática entre competição e governança, sugerindo que competição tem um efeito positivo sobre governança até certo nível. Em resumo, o estudo provê evidências da influência exercida pelas características da indústria sobre práticas de governança corporativa.

Os resultados do estudo de Karuna (2008) diferem dos observados por Chou et al. (2008), pois estes encontram uma relação de substituição entre governança e competição, em linha com as predições de Allen e Gale (1999). Contudo, é interessante observar a relação quadrática obtida em um dos testes realizados por Karuna (2008). Tal relação enseja que governança e competição podem ser complementares até certo nível. Essa relação remete ao trabalho de Schimidt (1997), pois o autor prevê que a competição pode ser benéfica, dependendo da sua intensidade. Justamente o efeito encontrado por Karuna (2008).

\subsubsection{Grau de incentivo oferecido aos gestores}

Karuna (2007) e Cuñat e Guadalupe (2004; 2005) estudam o efeito da competição sobre os incentivos oferecidos aos gestores.

Karuna (2007) responde esta questão por meio da investigação de um dos mecanismos internos de governança corporativa, que é o incentivo oferecido aos gestores para o alinhamento de seus interesses aos dos acionistas. Especificamente, o teste principal da 
pesquisa é realizado com base nos incentivos oferecidos ao diretor-presidente da companhia. Karuna (2007) utiliza como métrica de competição no mercado de produtos três aproximações, a saber: i) existência de produtos substitutos; ii) custos (barreiras) de entrada; e iii) tamanho do mercado. Ademais, o autor ainda emprega o índice de concentração C4 (soma da participação de mercado das quatro principais companhias) como uma aproximação para a competição. No principal teste do trabalho, o autor utiliza um período de 12 anos (19922003), com uma amostra de 1579 companhias norte-americanas. O principal resultado do trabalho é que firmas oferecem expressivos incentivos aos seus gestores quando a competição no mercado de produtos aumenta. A variável $\mathrm{C} 4$ apresentou ambigüidades na natureza do relacionamento entre incentivos e concentração. Esse resultado é útil para trabalhos que utilizarem medidas unívocas de concentração como aproximação para competição, como é o caso desta dissertação Outro aspecto também relevante foi a constatação da complementaridade entre os incentivos oferecidos pela companhia e competição na indústria.

Cuñat e Guadalupe (2004) estudam os efeitos da competição no mercado de produtos sobre o pacote de remuneração oferecido aos gestores nos Estados Unidos. Ao todo, cerca de 22.000 observações são utilizadas na pesquisa, cujo período compreendeu os anos de 1992 a 2000. As variáveis utilizadas como proxy de incentivo são a remuneração do executivo durante o ano, remuneração do executivo somada a todos os bônus recebidos e o valor total das opções de ações concedidas, calculo pelo modelo de Black-Scholes. O C4 e um experimento valendo-se de duas alterações nas regulamentações ocorridas no setor bancário e financeiro são utilizados para aferir a competição no mercado de produtos. Os resultados indicam que o efeito da competição no mercado de produtos é aumentar a sensibilidade do pagamento por desempenho, indicando que quando a competição aumenta, os gestores serão beneficiados por um aumento nos incentivos.

Em um segundo estudo, Cuñat e Guadalupe (2005) estudam como os pagamentos baseados em desempenho variam para o principal executivo, diretores e demais empregados após mudança da competição no mercado de produtos. Dessa vez, o trabalho utiliza companhias do Reino Unido. São utilizadas 22.183 observações, em um período de 1992-2000. Como proxy de remuneração, os autores utilizam dados sobre a remuneração total auferida pelo principal executivo, diretores e demais executivos. A alta e inesperada apreciação da libra esterlina em 1996 foi utilizada como uma forma de identificar impactos no nível de competição no 
mercado de produtos, dependendo de quanto exposta ao comércio exterior estava a firma, sendo que o índice de penetração das importações e a participação das exportações. Os resultados indicam que setores mais expostos à competição externa aumentaram o nível de remuneração atrelada ao desempenho após a apreciação cambial comparativamente mais do que setores menos expostos à competição externa.

\subsubsection{Substituição do CEO}

Coffee (1999) afirma que firmas com sistemas de governança corporativa eficientes penalizam seus gestores por mau desempenho. Portanto, para o autor, um indicativo de bom sistema de governança corporativa seria a sensibilidade da substituição dos gestores ao desempenho alcançado, principalmente do diretor-presidente. Para Mendes-da-Silva e Moraes (2004), essa sensibilidade demonstraria a atuação do conselho de administração da companhia em prol do interesse dos acionistas.

Nesse sentido, DeFonde e Park (1999) investigam se a substituição de diretores-presidente é mais frequente em indústrias mais competitivas e se a frequência de substituição de diretorespresidente é mais diretamente associada com medidas de desempenho relativo, baseadas em métricas contábeis, em indústrias com alta competição do que em indústrias com baixa competição. Foram estudadas 301 firmas nos Estados Unidos, em um período de 5 anos, de 1988-1992. Os autores coletaram sobre a freqüência de substituição do diretor-presidente. Como aproximação do conceito de competição no mercado de produtos, o HHI foi empregado no estudo. Os autores encontram que a frequência de substituição do diretor-presidente aumenta com a diminuição do HHI, sugerindo que quanto maior a competição, maior a freqüência de substituição dos gestores. Outro importante resultado do trabalho é o fato de que a utilização da avaliação por meio de desempenho relativo está mais associada à substituição de diretores-presidente apenas em indústrias mais competitivas. O resultado do estudo, segundo os autores, implica que as evidências contraditórias a respeito da utilização de ferramentas que consideram o desempenho relativo como forma de avaliação foram ocasionados pela ausência da variável "competição" nos testes empíricos. Como complemento, o estudo de Fee e Kadlock (2000) apresenta resultados semelhantes aos do trabalho de Defond e Park (1999). Os autores estudam o setor de jornais dos EUA. Os 
achados dos estudos apontam para a conclusão de que quanto maior a competição no setor, maior a taxa de substituição do diretor-presidente.

\subsubsection{Conselho de Administração}

Com relação aos estudos sobre Conselho de Administração, dois foram incluídos na pesquisa. O primeiro, de Randoy e Jenssen (2004), discute a questão da independência vinculada à competição no mercado de produtos. O segundo, de Bozec (2005), investiga a efetividade do conselho em função da competição no mercado de produtos.

Conselhos de Administração compostos por maioria de membros independentes é considerada uma boa prática de governança corporativa (IBGC, 2009, p. 37). A idéia básica é que conselheiros mais independentes tenderiam a ser melhores monitores da gestão da companhia em comparação a conselheiros internos. Assim, Randoy e Jenssen (2004) estudam a relação entre independência do conselho de administração, competição no mercado de produtos e desempenho da companhia, no mercado sueco, entre os anos de 1996 e 1998. A amostra do estudo é composta por uma amostra de 98 companhias. Essencialmente, o mote do artigo foi extraído do trabalho de Nickell (1997). Os autores argumentam que o potencial conflito de interesses entre proprietários e gestores pode ser menos severo em indústrias submetidas à alta competição. Os autores também se baseiam nos trabalhos de Nickell (1996) e Allen e Gale (1999) para afirmar que mercados monopolísticos são uma precondição necessária à ineficiência e improdutividade organizacional no longo prazo. A competição no mercado de produtos é calculada por uma medida denominada Price Cost-Margin (PCM), comumente utilizada como aproximação para o Índice de Lerner. Independência do conselho é mensurada pelo percentual de conselheiros externos em relação ao total de membros do conselho. Os resultados do trabalho indicam que firmas operando em mercados mais competitivos poderiam ter menos conselheiros externos e, ao contrário, companhias operando em mercados menos competitivos tendem a estruturar conselhos com mais membros externos. Randoy e Jenssen (2004) alegam que a competição desempenha o papel de mecanismo alternativo à independência do conselho de administração. Os autores expõem de forma clara as implicações da pesquisa para as boas práticas de governança corporativa. Firmas em indústrias mais competitivas poderiam, de acordo com a pesquisa, ter menos membros 
independentes no conselho. Por outro lado, companhias operando em mercados menos competitivos poderiam ter mais membros independentes.

Bozec (2005) investiga a interação entre as características do conselho de administração e disciplina de mercado sobre o desempenho da companhia. O trabalho é realizado com 25 companhias estatais canadenses, compreendendo o período de 1976 a 2000. Para estudar as características do conselho, o autor analisa a estrutura do conselho e a existência de comitês. Em relação à estrutura, são analisados o tamanho, uma variável binária indicando se o cargo de CEO e presidente do conselho é ocupado pela mesma pessoa, o percentual de executivos que não ocupam cargos da companhia e o percentual de membros do conselho que são funcionários públicos. A competição no mercado de produtos foi aproximada por meio de uma variável binária, cuja função é identificar se a companhia estatal é monopolista ou se a companhia possui concorrentes no mercado. Um primeiro resultado do estudo é que competição no mercado de produtos impacta positivamente o desempenho da firma. Além disso, o estudo constata que a competição no mercado de produtos propicia condições para que o efeito do conselho de administração sobre o desempenho seja identificado. Outro resultado importante é a constatação de que a independência do conselho de administração é relacionada com desempenho negativo e baixa produtividade quando as companhias estatais são submetidas a alta competição. Por fim, o estudo conclui que os comitês do conselho não apresentaram relação com o desempenho da companhia.

\subsubsection{Benefícios privados do controle}

Guadalupe e Pérez-Gonzáles (2006, p. 1) afirmam que uma visão muito difundida entre os economistas é que a competição no mercado de produtos melhora a governança corporativa. Dick e Zingales (2004, p. 29) apontam essa competição como uma possível inibidora da extração dos benefícios advindos do controle das firmas. Para testar esta hipótese, Guadalupe e Pérez-Gonzáles (2006) utilizam como indicativo de governança corporativa os benefícios privados do controle, aproximados pela diferença entre o preço das ações com direito a voto e sem direito a voto da mesma empresa.

O trabalho dos autores visa a responder duas questões: Há indícios que a competição no mercado de produtos melhora a governança corporativa? Caso a resposta seja sim, por qual 
canal isso ocorre? Para mensurar competição, os autores utilizaram duas métricas: i) nível médio de importações do setor; ii) Regulação do Mercado de Produtos (PMR), uma medida desenvolvida pela OCDE, que visa a mensurar o grau pelas quais as políticas inibem ou incentivam a competição. Essa última métrica é amplamente explicada no trabalho de Conway et al. (2005). Foram estudadas 554 firmas em 19 países, entre 1998 e 2003.

Guadalupe e Pérez-Gonzáles (2006) encontram que a competição no mercado de produtos apresenta forte correlação negativa com o prêmio pelo voto. Um aumento de $5 \%$ na competição média da indústria resulta em uma diminuição do prêmio pelo voto em 3,5\%. Os autores também encontram que os benefícios privados do controle são menores em países com leis rígidas. Outro resultado foi que a competição é significativamente correlacionada com baixo prêmio pelo voto. Este resultado aponta que competição pode reduzir os benefícios privados do controle. $\mathrm{O}$ grande diferencial da pesquisa foi investigar um potencial canal pelo qual a competição poderia reduzir os benefícios privados do controle. Para tanto, os autores utilizam um índice extraído do trabalho de Parrino (1997). Tal índice é utilizado como uma aproximação da vantagem de dispersão das informações com o aumento do número de firmas em uma indústria. Este índice testa se o impacto da competição difere em função da homogeneidade da indústria. $\mathrm{O}$ achado do estudo aponta que mudanças no grau de competição, mensurado pelo índice de importação, são apenas relevantes quando a firma opera de uma indústria homogênea. Por fim, mais um interessante achado do estudo foi o fato de que o impacto da competição no prêmio pelo voto tende a ser estatística e economicamente mais significativo em indústrias mais concentradas.

No Brasil, em função da estrutura patrimonial de diversas companhias ser compostas por dois tipos de ações, ordinárias e preferenciais, que conferem diferentes espécies de direitos aos acionistas, há a possibilidade de se estudar o impacto da competição no mercado de produtos sobre a diferença de preços entre tais tipos. No entanto, conforme explicam Saito e Silveira (2007, p. 4), não seria possível estudar o prêmio pelo voto, e sim a diferença de preço entre as ordinária e preferenciais, denominada pelos autores de Dual Class Premium (DCP). 


\subsubsection{Utilização de cláusulas antitakeovers}

De acordo com Goergen et al. (2005, p. 6), as regulamentações sobre takeover são importantes para mitigar o conflito de interesses entre diversas partes interessadas na companhia, como gestores, acionistas e demais stakeholders. Ainda segundo os autores, regulamentações sobre takeover têm um impacto direto sobre o problema de agência entre gestores e acionistas, controladores e minoritários, e demais stakeholders. Portanto, Goergen et. al (2005, p. 6) afirmam que tais regulamentações constituem-se em importantes elementos do sistema de governança corporativa. Bebchuk (2003, p. 714) afirma que companhias adotam medidas antitakeover de dois modos. A primeira é por meio da inserção de cláusulas que dificultam a aquisição do controle da companhia em seus contratos sociais. A segunda é por meio da realização de operações em jurisdições que possuam leis que dificultem a tomada de controle da empresa.

Em relação ao primeiro modo, o seguinte questionamento emerge: quais fatores influenciam a adoção de cláusulas antitakeover pelas companhias? Cremers et al. (2008) visam a responder tal questionamento levando em conta o impacto do ambiente competitivo no qual a companhia está inserida. Em síntese, a pesquisa estuda o efeito da competição no mercado de

produtos sobre o número de cláusulas antitakeover adotado pelas companhias. Os autores utilizam um período de 14 anos (1990-2003) para a elaboração do estudo e 873 observações advindas do mercado norte-americano. Como aproximação para competição, o HHI e a margem de lucro mediana da indústria são utilizados. Os resultados dos testes estatísticos indicam que mais competição é associada com mais defesas antitakeover. Como os resultados contrariam as evidências na literatura utilizadas como base para o desenvolvimento do trabalho, os autores testam duas hipóteses como potenciais explicações para os resultados. A primeira hipótese é que competição e o mercado de controle corporativo são substitutos. A segunda é que em ambientes mais competitivos os custos de agência tendem a ser maiores, visto que os gestores podem solicitar a utilização de tais defesas. Todavia, os autores inovam e inserem uma variável com o intuito de capturar o incentivo dos stakeholders em monitorar as atividades da companhia, especificamente o relacionamento da companhia com seus clientes e fornecedores. Para companhias com relacionamentos de longo prazo com clientes e fornecedores, a competição no mercado de produtos está positivamente relacionada com a adoção de cláusulas antitakeover, sugerindo interesse dos stakeholders em não permitir que a companhia troque de controle, a fim de não prejudicar o relacionamento comercial. Os autores 
constatam que a relação entre competição no mercado de produtos e adoção de cláusulas antitakeover em indústrias nas quais as relações entre companhia, fornecedores e clientes tendem é negativa, ou seja, quanto maior competição, menos cláusulas. Portanto, esse relacionamento entre companhia, fornecedores e clientes explica a relação positiva observada nos primeiros testes estatísticos do estudo.

Kadyrzhanova e Kropf (2007) estudam se os efeitos de medidas antitakeover sobre o valor das companhias variam em função do grau de concentração da indústria. Para tanto, os autores desenvolvem um modelo analítico e o testam. Uma amostra de aproximadamente 1500 companhias norte-americanas, em um período de 16 anos, 1990 a 2005, é utilizada nos testes estatísticos. Como proxy de governança corporativa, no estudo são empregadas diversas métricas, a saber: i) índice que capta a existência de um conselho de administração qualificado e poison pills; ii) "G-index" desenvolvido por Gompers et al. (2003); iii) "E-index" desenvolvido por Bebchuck et al.(2004); e iv) posse de ações por parte de investidores institucionais, fundos de pensão e agentes internos à companhia. Em relação à competição no mercado de produtos, também são utilizadas diversas aproximações: i) HHI; ii) C4; iii) taxa de penetração das importações; e iv) número de competidores. Em síntese, os resultados empíricos do trabalho evidenciam que firmas em indústrias mais concentradas tendem a adotar mais cláusulas antitakeover. Além disso, cláusulas antitakeover estão associadas com alto valor da firma, mas apenas em indústrias concentradas. Por fim, em indústrias menos concentradas, as cláusulas antitakeover estão ligadas à destruição de valor da companhia.

O mote destes estudos pode ser útil para pesquisas no mercado brasileiro. Gorga (2008), em um estudo que discute as mudanças na estrutura de propriedade no mercado brasileiro, afirma que de uma amostra de 84 companhias listadas nos níveis diferenciados de governança corporativa na BMF\&BOVESPA, aproximadamente 56\% adotam alguma cláusula de proteção antitakeover. Portanto, pode-se investigar o efeito da competitividade no mercado de atuação das companhias com o fato de elas adotarem ou não cláusulas desse tipo. 


\subsubsection{Divulgação de informações}

A divulgação voluntária de informações é um dos princípios básicos de governança corporativa para o IBGC (2009). A idéia é que gestores possuem informações superiores e melhor entendimento sobre o desempenho da firma do que os investidores externos. Uma estratégia de divulgação voluntária de informações poderia desempenhar um importante papel na redução da assimetria informacional, cujo potencial resultado seria a diminuição nos custo do capital próprio (ALENCAR; LOPES, 2008) ou no custo do capital de terceiros (LIMA, 2009). Diversos determinantes do disclosure pelas companhias são estudados. Entre eles, a competição no mercado de produtos vem sendo estudada por pesquisas internacionais. Shin (2002) e Li (2010) são exemplos.

Shin (2002), em um trabalho composto por 416 companhias americanas, analisadas no período de 1987 a 1995, mostra que a competição no mercado de produtos impacta significativamente na decisão de a empresa evidenciar ou não informações voluntariamente. Isso dependerá do tipo de competição a que a companhia for submetida, essa é a hipótese básica do trabalho do pesquisador. Se a competição for relacionada à capacidade de produção, as empresas tenderão a evidenciar maior quantidade de informações. Caso a competição seja de preços, as companhias tenderão a evidenciar menos informações. Os resultados gerais do estudo confirmam as hipóteses levantadas pelo pesquisador.

Nessa mesma linha de pesquisa, Li (2010) estuda se a competição afeta a quantidade e qualidade de evidenciação voluntária de informações pelas companhias. Todavia, a autora diferencia sua pesquisa em relação às demais, na medida em que utiliza dois diferentes tipos de competição na pesquisa: i) competição proveniente de potenciais entrantes; e ii) competição proveniente de rivais já existentes no mercado de atuação da companhia. Como aproximação para o conceito de disclosure, Li (2010) utiliza a divulgação de projeções sobre os lucros e investimentos da companhia realizada pelos gestores. No trabalho, destaca-se o número de variáveis utilizadas como proxy para competição, nove ao todo. O objetivo da autora é empregar essas aproximações para conseguir separar os dois tipos de competição citados. A pesquisa é conduzida valendo-se apenas de companhias dos EUA, entre 1977 e 2007, abarcando um total de 27.053 indústrias no período. Os resultados do estudo indicam que a competição proveniente dos potenciais entrantes aumenta a quantidade de disclosure pelas companhias enquanto que a competição advinda dos rivais existentes a reduz. Ademais, 
Li (2010) encontra que até determinado nível de incentivo do mercado de capitais, a competição aumenta a qualidade do disclosure.

Por fim, é válido também citar a crítica de Karuna (2010) sobre o trabalho de Li (2010). De forma geral, Karuna (2010) questiona a capacidade de as métricas de competição utilizadas pela autora captar claramente a competição proveniente de potenciais entrantes ou rivais já existentes. Segundo o autor, há ambigüidade nas métricas utilizadas. Além disso, questiona a seleção da amostra, bem como a análise fatorial empregada no estudo para reduzir as variáveis de competição. Não obstante às críticas, Karuna (2010) destaca que o estudo de Li (2010) apresenta duas importantes contribuições para a literatura contábil. A primeira referese ao fato de estudar o efeito de diferentes tipos de competição sobre as escolhas de evidenciação das companhias. A segunda diz respeito ao estudo de como a competição afeta a divulgação de previsões sobre lucro e investimentos pelos gestores.

Os temas investigados e os resultados das pesquisas citadas são salutares para os pesquisadores engajados no entendimento do nível de informações divulgadas pelas companhias brasileiras, visto que a variável competição no mercado de produtos pode ser um importante determinante na decisão de a companhia divulgar ou não informações.

\subsubsection{Política de distribuição de dividendos}

A pesquisa de DeAngelo et al. (2004) conclui que as companhias pagam dividendos para mitigar os potenciais custos de agência que poderiam eventualmente surgir provenientes do excesso de caixa e baixo endividamento. Como pesquisas evidenciam (por exemplo, Griffith, 2001) que a competição no mercado de produtos pode impactar os custos de agência, há potenciais razões para estabelecer uma relação entre a política de dividendos de uma companhia e a competição no mercado de produtos.

Grullon e Michaely (2006) investigam se a relação entre competição no mercado de produtos e os incentivos concedidos aos gestores influenciam a política de distribuição de dividendos da companhia. As duas hipóteses analisadas pelos autores são as seguintes: i) firmas podem distribuir dividendos porque a competição exerce pressão sobre os gestores para distribuir os resultados do negócio para os acionistas da companhia; e ii) gestores podem usar a 
distribuição de dividendos como um substituto para fatores de disciplina externos e estabelecer uma boa reputação no mercado de capitais com o intuito de obter capital em melhores termos. O estudo é conduzido com uma amostra de 3.011 companhias dos Estados Unidos, no período de 1972 a 2001. Como aproximação para o grau de pagamento de dividendos, foram utilizadas métricas com o intuito de identificar o total de dividendos distribuídos em relação às vendas, total de ativos e valor de mercado das ações da companhia. Para estimar a competição no mercado de produtos, o HHI é utilizado. Os resultados do estudo validam a primeira hipótese. Segundo Grullon e Michaely (2006, p. 4), os efeitos da competição no mercado de produtos sobre a política de dividendos são significativos em firmas que possuem maior potencial de ocorrerem problemas de agência em razão da existência de fluxos de caixa livres.

\subsubsection{Desregulamentação de setores}

Outro campo fértil de estudos dos potenciais efeitos da competição sobre os mecanismos de governança corporativa ocorre após a desregulamentação de setores. Kole e Lehn (1997) afirmam que a desregulamentação de setores oferece um experimento natural para o estudo das mudanças nas estruturas de governança das companhias em função do incremento da competição no mercado de produtos. Karuna (2008) complementa a exposição de Kole e Lehn (1997) e afirma que a desregulamentação do setor de Cabo e Outros Serviços de Televisão Paga, nos EUA, provê uma interessante forma de estudar como um aumento na competição causado por fatores exógenos afeta as práticas de governança. Kole e Lehn (1999), Rennie (2006) e Karuna (2008) estudam o efeito da desregulamentação de setores sobre a estrutura de governança das companhias.

Kole e Lehn (1999) estudam as alterações nos mecanismos de governança corporativa do setor aéreo norte-americano após a desregulamentação do final da década de 70, mais precisamente em 1978. A pesquisa contempla 21 companhias e é realizada em um período de 22 anos, entre 19711 1992. Apesar de as implicações serem analisadas apenas para o setor aéreo, os autores afirmam que o trabalho também apresenta contribuições para outros três setores, a saber: telecomunicações, eletricidade e saúde. Os autores analisam alterações em três principais mecanismos de governança corporativa, a saber: i) estrutura de propriedade; ii)

remuneração dos executivos; iii) tamanho e composição do conselho. Segundo os autores, a 
desregulamentação altera a natureza dos conflitos de agência. Assim, para mitigar os novos problemas de governança corporativa, há alterações nos mecanismos de governança citados acima. Em síntese, a estrutura de propriedade tornou-se mais concentrada, houve retração no tamanho do conselho e um aumento na remuneração e substituição dos diretores-presidente. De acordo com os autores, as mudanças nas estruturas de governança corporativa observadas ocorreram de forma gradual. No entanto, alguns mecanismos não se comportaram conforme as predições da teoria, sugerindo diferenças nos custos e benefícios da adoção de determinados mecanismos de governança.

Rennie (2006) estuda como a desregulamentação do setor elétrico estadunidense alterou as estruturas de governança corporativa das companhias. Para tanto, a pesquisa utiliza uma amostra de 101 companhia do setor elétrico. Dois períodos são utilizados na realização da pesquisa. O primeiro, entre 1987 e 1990, compreende o momento antes da desregulamentação. O segundo, entre 1994 e 1997, compreende o período após a desregulamentação. $\mathrm{O}$ autor busca apresentar as mudanças na estrutura de governança do setor de energia estadunidense após a desregulamentação e explorar a relação ente alterações na competição no mercado de produtos e mudanças nas práticas de governança corporativa. Especificamente, são utilizados oito atributos para aferir a mudança na estrutura de governança corporativa das companhias, a saber: i) proporção de ações detidas pelo CEO; ii) proporção de ações detidas pelos membros da diretoria e do conselho de administração; iii) proporção de ações detidas por acionistas externos; iv) remuneração total do CEO; v) opções de ações concedidas ao CEO; vi) proporção de opções de ações recebidas pelo CEO em relação à sua compensação total; vii) número de conselheiros; e viii) proporção de conselheiros externos. A variação do HHI é utilizada para verificar a alteração da competição entre companhias após a desregulamentação. Os resultados do estudo mostram que companhias de energia elétrica incrementaram suas estruturas de governança corporativa após a desregulamentação, contudo não tanto quando comparadas às empresas industriais. Especificamente, as companhias apresentaram redução no número de membros do conselho, aumentaram a proporção de membros externos, aumentaram o percentual de remuneração de CEOs por meio de opções de ações. Além disso, houve aumento no número de ações sob controle do CEO e aumento da quantidade de ações por acionistas externos às companhias. Em síntese, o trabalho demonstra que o aumento da competição no mercado de produtos após 
um processo de desregulamentação explica as mudanças observadas na estruturas de governança corporativa das companhias.

Karuna (2008) estuda a desregulamentação do setor norte-americano de Cabo e Outros Serviços de Televisão Paga, em 1996, com o intuito de demonstrar como uma mudança na competição afeta as estruturas de governança corporativa das companhias. Os resultados do estudo do autor complementam os achados dos trabalhos de Kole e Lehn (1999) e os de Rennie (2006), pois Karuna (2008) encontra substanciais alterações nas estruturas de governança corporativa nos anos subsequentes a desregulamentação do setor, concluindo que processos de desregulamentação são úteis para explicar alteração na estrutura de governança corporativa das companhias.

\subsubsection{Competição, governança e valor}

O efeito das práticas de governança sobre o valor da companhia está documentado em diversos trabalhos acadêmicos, entre os quais podem ser destacados os de Klapper e Love (2002), Beiner et al. (2004), Brown e Caylor (2006), Black et al. (2006), Bai et al. (2003), Leal e Carvalhal da Silva (2005), Silveira e Barros (2007). Investigando essa mesma relação, porém inserindo variáveis para captar o efeito da competição, têm-se as pesquisas de Giroud e Mueller (2008), Beiner et al. (2009) e Ammann et al. (2010), apresentadas a seguir.

Giroud e Mueller (2008) realizam uma série de testes empíricos para identificar o efeito da competição no relacionamento entre governança e valor. $O$ trabalho é conduzido exclusivamente com empresas norte-americanas, entre 1990 e 2006. Ao todo, 3.241 companhias são utilizadas como amostra para a pesquisa. A hipótese central do trabalho dos autores é que se os gestores de firmas em indústrias competitivas tiverem menos opções de condutas a não ser maximizar o valor da empresa, então firmas em tais ambientes se beneficiariam menos de boas práticas de governança corporativa. Como aproximação de qualidade de governança corporativa, os autores valem-se dos índices desenvolvidos por Gompers et al. (2003) e Bebchuk et al. (2004). Como aproximação de competição no mercado de produtos, os autores utilizam o HHI. 
As evidências apresentadas no trabalho de Giroud e Mueller (2008) suportam a hipótese de que firmas em mercados mais concentrados se beneficiam mais de melhores práticas de governança corporativa. Os efeitos das boas práticas de governança são significativos apenas no desempenho das ações, desempenho operacional e valor apenas em indústrias menos competitivas. Mediante testes adicionais, os autores identificam mais dois importantes resultados: i) firmas com boa governança corporativa exibem significativo lucro por ação apenas quando a competição é fraca; ii) aparentemente, analistas entendem que boa governança tem um efeito positivo no retorno das ações apenas em indústrias entendidas como menos competitivas. $\mathrm{Na}$ análise do $\mathrm{Q}$ de Tobin, os autores encontram resultados consistentes com os apresentados acima. O efeito da governança sobre o Q de Tobin só foi estatisticamente significativo em companhias em ambientes menos competitivos. Referente ao efeito da governança sobre o desempenho operacional da firma, mensurados pelo retorno sobre ativo, margem de lucro líquida e retorno sobre ações, em todas as especificações os resultados só se mostram significativos nos casos em que a firma opera em ambientes menos competitivos. Duas principais contribuições provenientes do trabalho dos autores são a possibilidade de pesquisadores se beneficiar da interação entre competição e governança em suas pesquisas e o suprimento de evidência para os reguladores sobre o impacto relevante dos mecanismos de governança corporativa em ambientes menos competitivos.

Beiner et al. (2009), além de desenvolverem um modelo teórico, apresentado na seção 2.3, também empregam testes estatísticos a fim de verificar as predições de seu modelo. Os autores investigam se os gestores trabalham de forma mais eficiente quando o ambiente no qual a firma opera é mais competitivo. A pesquisa é conduzida com uma amostra de 199 a 2004 companhias suíças, entre 2002 e 2005. Os autores utilizam três aproximações para a variável competição no mercado de produtos, a saber: i) HHI; ii) margem líquida de lucro mediana; e iii) uma métrica que estimada a renda econômica, denominada Rents. Como proxy de incentivos aos gestores e governança, os autores utilizam o percentual de pagamento baseado em ações em relação à remuneração total, a sensibilidade do pagamento em relação ao desempenho da companhia, o percentual de ações em posse de executivos e conselheiros, o percentual de ações votantes em posse por acionistas externas detentores de mais de $5 \%$ de ações, o percentual de conselheiros independentes e o endividamento da companhia. As principais conclusões do estudo podem ser resumidas da seguinte forma: i) maior intensidade de competição está associada com esquemas de incentivos mais fortes; ii) a relação entre incentivos aos gestores e competição tende a ser convexa, indicando que o efeito marginal da 
competição nos incentivos gerenciais aumenta em função intensidade da competição no mercado de produtos até um certo nível de competição; e, iii) outro resultado interessante foi os autores terem encontrado um relação negativa entre competição no mercado de produtos e valor da firma, em linha com as predições do modelo. No entanto, quando os autores incluem na análise uma potencial não-linearidade, há um ponto em que o efeito da competição no valor da firma torna-se positivo, indicando que determinados níveis de competição trazem benefícios para a companhia.

Em recente pesquisa, Ammann et al. (2010) utilizam uma amostra 3.102 companhias provenientes de 14 países europeus para estudar a relação entre competição no mercado de produtos, governança corporativa e valor da firma. A pesquisa é conduzida em um período de 5 anos, entre 2003 e 2007. A escolha de países europeus para a pesquisa, segundo Ammann et al.(2010, p. 2), deve-se ao fato de grande parte dos estudos sobre o tema ter sido realizada nos EUA, sem, no entanto, chegar a uma conclusão sobre o relacionamento entre as variáveis. De certa forma, os autores realizam uma crítica sobre os trabalhos que empregaram apenas os índices desenvolvidos por Gompers et al.(2003) e Bebchuck et al. (2004) como uma aproximação para qualidade de governança corporativa, tendo em vista que ambos os índices contêm aspectos relacionados a cláusulas antitakeover. Assim, desconsideram outras dimensões de governança corporativa. Ammann et al. (2010) utilizam um amplo índice de governança elaborado pela Governance Metrics International (GMI), que possui 64 diferentes atributos de governança corporativa e é dividido em seis categorias ${ }^{14}$. O HHI é a variável utilizada no estudo como aproximação para competição. Na pesquisa, os autores se baseiam principalmente nos trabalhos de Kadyrzhanova e Rhodes-Kropf (2007) e Giroud e Mueller (2008). Por meio de diferentes abordagens metodológicas, a pesquisa indica que a qualidade de governança corporativa é positiva e significativamente correlacionada com valor, mensurado na pesquisa pelo Q de Tobin, apenas para empresas que operam em setores menos competitivos. Logo, os resultados são consistentes com a hipótese de que competição no mercado de produtos atua como um substituto às boas práticas de governança corporativa.

\footnotetext{
${ }^{14}$ As categorias são divididas em: i) funcionamento e responsabilidade do conselho de administração; ii) disclosure de informações financeiras; iii) direito dos acionistas; iv) remuneração; v) mercado para controle; e vi) comportamento corporativo.
} 


\subsubsection{Competição, governança e desempenho}

Por fim, cabem algumas considerações sobre o relacionamento entre competição, governança e desempenho. De acordo com Bhagat et al. (2007, p. 12), a literatura empírica não identifica um relacionamento conclusivo entre governança corporativa e desempenho da firma. Bohren e Odegaard (2003) atribuem essa dificuldade em estabelecer um claro relacionamento entre as variáveis ao fato de não haver uma teoria bem definida, visto que não é conhecido se os diversos mecanismos de governança interagem de forma complementar ou substituta. Assim, a seguinte pergunta emerge: todas as firmas se beneficiam de boas práticas de governança corporativa? O trabalho de Allen e Gale (1999) apresentado em 2.3 enseja este questionamento, pois, de acordo com o modelo teórico desenvolvido pelos autores, em ambientes competitivos os mecanismos de governança corporativa seriam substituídos pelo poder disciplinador da competição.

Nestas discussões, o estudo da influência da competição pode colaborar no entendimento do relacionamento entre as variáveis. Mayers (1996) discorre sobre a importância de investigar a interação entre governança, competição e desempenho. Segundo o autor, competição no mercado de produtos é associada com a alocação eficiente de recursos, em razão de fornecedores de mercadorias e serviços serem incentivados a oferecer produtos com menores custos e preços. Primeiramente, o autor afirma que a efetividade dos diferentes tipos de mecanismos de governança pode ser influenciada pelo nível de competição no mercado de produtos. Em segundo lugar, a forma como a governança corporativa é estruturada nos países pode depender do grau de competição no mercado de produtos. Assim, segundo Mayers (1996), esforços para aumentar o grau de competição podem causar efeitos relevantes sobre a função da governança corporativa, podendo ocasionar um incremento no desempenho das firmas.

Estudos como os de Januszewski et al. (2001), Griffith (2001), Grosfeld e Tressel (2001), Koke e Renneboog (2003), Li e Niu (2006), Pattanayak (2008) e Giroud e Mueller (2009), realizados na Alemanha, Reino Unido, Polônia, comparativo entre Alemanha e Reino Unido, China, Índia e Estados Unidos, respectivamente, corroboram a importância de se estudar a interação entre competição no mercado de produtos e governança sobre o desempenho das firmas. 
Januszewski et al. (2001) analisam o papel da competição no mercado de produtos e governança corporativa como determinantes do crescimento da produtividade nas firmas de manufatura alemãs, no período de 1986 a 1994, para uma amostra de 491 companhias. Os autores se concentraram no setor manufatureiro em função da dificuldade estimar e mensurar modelos empíricos de produtividade para o setor de serviços. A métrica de governança utilizada pelos autores se restringiu à estrutura de propriedade das companhias. Em relação às métricas de competição, os autores utilizam uma métrica denominada Rent, cuja idéia é estimar a renda econômica, extraída do trabalho de Nickell (1996), HHI, C6 e taxa de penetração das importações. Januszewski et al. (2001) encontram que firmas obtêm altas taxas de crescimento da produtividade quando operam em mercados com intensa competição. Além disso, constatam que competição e controle rígido são complementares, ou seja, o efeito positivo da competição é potencializado pela presença de um grande investidor. Alguns resultados não foram estatisticamente significativos, assim os autores sugerem que métricas alternativas de competição sejam utilizadas em futuras pesquisas, principalmente alterações no nível de competição decorrentes de eventos exógenos. Por exemplo, a desregulamentação de um setor.

Griffith (2001) investiga se um aumento da competição no mercado de produtos tem impacto nos níveis de produtividade e taxa de crescimento, se esse efeito é positivo ou negativo, e se o aumento da competição leva a uma mudança nos níveis de produtividade por meio da redução dos custos de agência. O estudo é conduzido considerando o período entre 1980 e 1996, no Reino Unido, com aproximadamente 103.500 observações. A autora separa os estabelecimentos estudados na pesquisa em quatro diferentes grupos, a fim de identificar os que possuem mais chance de ocorrer problema agente-principal: i) estabelecimento administrado pelo proprietário; ii) estabelecimento com subsidiárias; iii) estabelecimentos administrados pelo poder público; e iv) outros. O programa de criação de um mercado único europeu é utilizado como uma mudança exógena no nível de competição no mercado de produtos, sendo que o Índice de Lerner é aplicado para demonstrar o possível incremento no nível de competição. Os resultados sugerem que um aumento da competição no mercado de produtos está associado a um aumento da produtividade das companhias, sendo que os aumentos não foram constatados em firmas que não havia previamente um potencial para o problema agente-principal, mas sim naquelas em que havia. Segundo Griffith (2001), os 
resultados oferecem fortes evidências empíricas de que o aumento da competição no mercado de produtos aumenta a produtividade das companhias por meio da mitigação dos custos de agência.

Grosfeld e Tressel (2001) estudam o impacto da inter-relação entre competição e governança sobre o desempenho na Polônia. Especificamente, o objetivo dos autores é verificar se as variáveis de governança corporativa e competição agem como complementares ou substitutas no relacionamento com o desempenho das companhias. Uma amostra de 200 companhias, entre 1991 e 1998, é utilizada na pesquisa. A estrutura de propriedade é utilizada como aproximação para governança e uma medida denominada Rent, que pode ser traduzida como renda econômica, é a aproximação para competição. Uma função de produção Cobb Douglas é utilizada como a variável dependente do estudo. O resultado principal do estudo refere-se ao impacto significativo e positivo da competição sobre o desempenho. Em relação à concentração da estrutura de propriedade, os autores encontram uma relação quadrática negativa com o nível de competição. Outro resultado importante do estudo diz respeito à complementaridade encontrada entre governança e grau de competição, sugerindo o reforço de uma sobre a outra. Segundo os autores, competição não tem um impacto significativo no crescimento da produtividade em firmas com pobre governança corporativa. Ao contrário, tem um significativo efeito em firmas com boa governança. Portanto, o trabalho de Grosfeld e Tressel (2001) conclui haver um relacionamento de complementaridade entre governança e competição.

Koke e Renneboog (2003) investigam o impacto da competição no mercado de produtos e governança corporativa sobre o crescimento da produtividade total dos fatores para duas amostras de companhias da Alemanha e do Reino Unido. Na Alemanha, o período do estudo vai de 1986 a 1996 e utiliza uma amostra de 1074 companhias. No Reino Unido, o período vai de 1992 a 1999 e utiliza uma amostra de 502 companhias. O principal resultado do estudo é que governança corporativa e competição no mercado de produtos afetam significativamente o aumento da produtividade das companhias; contudo o resultado varia entre Alemanha e Reino Unido, sendo que o papel do bloco de controle e do banco credor é particularmente importante em firmas com fraco desempenho. 
Na China, Li e Niu (2006) também estudam a inter-relação entre competição, governança e desempenho. A questão de pesquisa central é a seguinte: Governança corporativa e competição na China são substitutas ou complementares? O objetivo é acrescentar a interação entre governança corporativa e competição no mercado de produtos como um aspecto a ser observado quando se discute desempenho, medido, nesse trabalho, por produtividade. $\mathrm{O}$ trabalho utiliza uma amostra de 3822 companhias e um período de 6 anos, de 1998 a 2003. Para aproximar governança corporativa são utilizadas três métricas: i) estrutura de propriedade; ii) composição do conselho de administração; e iii) alguns aspectos concernentes à remuneração dos principais executivos. Para mensurar a variável competição, os autores valem-se da medida Rent, extraída do trabalho de Nickell (1996). A variável dependente do estudo é a produtividade das empresas, aproximada por uma função de produção CobbDouglas com dois fatores explicativos. Os resultados do trabalho não respondem objetivamente a questão de pesquisa, pois se apresentam diferentes à medida que são analisadas diferentes aproximações para governança corporativa. Há uma relação de complementaridade entre estrutura de propriedade e competição, e de remuneração e competição. Contudo, entre conselho de administração e competição a relação é de substituição. Portanto, não há uma conclusão única. Todavia, o trabalho demonstra que a interação entre competição e governança impacta significativamente a produtividade da firma.

No estudo de Pattanayak (2008), o objetivo é contribuir com a literatura sobre a relação entre governança corporativa, competição no mercado de produtos e os efeitos sobre o nível de produtividade da firma na perspectiva de um país emergente, no caso a Índia. A pesquisa utiliza uma amostra de 1660 companhias, em dois períodos: i) 2000 a 2001; e ii) 2003 a 2004. Como aproximação de governança corporativa, os autores utilizam a estrutura de propriedade e o grau de endividamento da companhia. Para mensurar a competição no mercado de produtos, HHI, C4, participação de mercado e uma medida de renda econômica são utilizados. O principal resultado do estudo mostra que companhias com ações concentradas sob a propriedade de famílias fundadoras são mais produtivas unicamente quando submetidas a intensa competição no mercado de produtos.

Por fim, Giroud e Mueller (2009) estudam se a competição mitiga o desleixo gerencial utilizando variações exógenas de governança corporativa, por meio de alterações em 30 leis sobre combinação de negócios, aprovadas entre 1985 e 1991, analisando estado por estado. A 
pesquisa utiliza como amostra um total de 10.960 companhias norte-americanas, entre 1976 e 1995. Na pesquisa, as mudanças nas leis de combinação de negócios são utilizadas como uma aproximação de governança corporativa. Nos testes de robustez, o "G-index" e o "E-index" também são utilizados para aproximar a qualidade de governança corporativa. O HHI é utilizado como proxy para competição no mercado de produtos. Em resumo, os resultados do estudo indicam que firmas operando em mercados menos competitivos experimentam uma significante retração em seu desempenho operacional após a mudança das leis, enquanto que firmas operando em mercados mais competitivos virtualmente não sofreram quaisquer efeitos, cujo achado é consistente com a idéia de que competição mitiga o desleixo gerencial.

\subsubsection{Sumário dos estudos}

No Quadro $2^{15}$, há um resumo dos trabalhos. Nele estão discriminados os autores, categoria, questão/relação estudada, país, amostra, período, as principais bases de dados utilizadas, técnica econométrica principal, proxy de governança corporativa, proxy de competição no mercado de produtos e os principais resultados.

\footnotetext{
${ }^{15} \mathrm{O}$ Quadro 2 está ordenado por categoria.
} 
Quadro 2-Resumo dos principais estudos analisados

\begin{tabular}{|c|c|c|c|c|c|c|c|c|c|}
\hline Autor (es) & Título & Categoria & Questão de pesquisarelaçãoestudada & $\begin{array}{l}\text { País(es)/Amostra/ } \\
\text { Período }\end{array}$ & $\begin{array}{l}\text { Base(s) de dados } \\
\text { principal(is) }\end{array}$ & $\begin{array}{l}\text { Técnica(s) } \\
\text { econonétrica (s) } \\
\text { principal (is) }\end{array}$ & $\begin{array}{l}\text { Proxy de governança } \\
\text { corporativia }\end{array}$ & $\begin{array}{l}\text { Proxy de competição no } \\
\text { mercado de prodiltos }\end{array}$ & Principal(is) resultado(s) \\
\hline $\begin{array}{l}\text { Guadalupe e } \\
\text { Pérez-Gonzáles } \\
\text { (2006) }\end{array}$ & $\begin{array}{l}\text { The Impact of } \\
\text { Product Market } \\
\text { Competition on } \\
\text { Private Benefits } \\
\text { of Control }\end{array}$ & $\begin{array}{l}\text { Benefícios } \\
\text { pivados do } \\
\text { controle }\end{array}$ & $\begin{array}{l}\text { Investiga se o grau de competição no } \\
\text { mercado de produtos afeta o prêmio } \\
\text { pelo voto entre açốes com differentes } \\
\text { direttos de voto. }\end{array}$ & $\begin{array}{l}\text { 19páíses } \\
554 \text { companhias } \\
1998-2003\end{array}$ & $\begin{array}{l}\text { i) Datastream; } \\
\text { ii) Worldscope; } \\
\text { iii) Compustat Global; e } \\
\text { iv) OCDE. }\end{array}$ & $\begin{array}{l}\text { i) Regresesão em cross- } \\
\text { section estimada por } \\
\text { OLS; } \\
\text { ii) Painel unilizando a } \\
\text { técnica de efeitos } \\
\text { fixos; } \text { e } \\
\text { iii) OLS em dois } \\
\text { estágios. }\end{array}$ & $\begin{array}{l}\text { Diferença de preço das ações } \\
\text { com diretos diferenciados de } \\
\text { voto em relação à demais. }\end{array}$ & $\begin{array}{l}\text { i) grau de penetração das } \\
\text { importações; e } \\
\text { ii) Product Market } \\
\text { Regulation (PMR). }\end{array}$ & $\begin{array}{l}\text { Competição é negativa e fortemente } \\
\text { correlacionada como prêmio pelo voto, sendo } \\
\text { que umaumento de } 5 \% \text { no nível de impoitação } \\
\text { é correlacionado comumdeclínio médio } 3,5 \% \\
\text { no prêmio pelo voto. O eféto é particulamente } \\
\text { significante emindústrias mais concentradas e } \\
\text { países comambiente legal mais fraco. }\end{array}$ \\
\hline $\begin{array}{l}\text { Randoye } \\
\text { Jenssen (2004) }\end{array}$ & $\begin{array}{l}\text { Board } \\
\text { Independence } \\
\text { and Product } \\
\text { Market } \\
\text { Competition in } \\
\text { Swedish Fims }\end{array}$ & $\begin{array}{l}\text { Consellho de } \\
\text { Administraçãa }\end{array}$ & $\begin{array}{l}\text { Oestudo investiga se o nível de } \\
\text { independência do conselho de } \\
\text { administração tem relação coma } \\
\text { competiçăo no mercado de produtos. }\end{array}$ & $\begin{array}{l}\text { Suécia } \\
98 \text { companhias } \\
1996-1998\end{array}$ & $\begin{array}{l}\text { Relatórios anuais das } \\
\text { companhias e outras } \\
\text { fontes de informaç̃ões } \\
\text { sobre governança } \\
\text { corporativa. }\end{array}$ & $\begin{array}{l}\text { Regressão em cross- } \\
\text { section estimada por } \\
\text { OLS. }\end{array}$ & $\begin{array}{l}\text { Éutitizada a independência do } \\
\text { consellho de administração, } \\
\text { mensurarada pelo perentual de } \\
\text { conselheiros externos em } \\
\text { relação ao total de membros do } \\
\text { conselho. }\end{array}$ & $\begin{array}{l}\text { Mensurada pela margem de } \\
\text { lucros média da indústria. }\end{array}$ & $\begin{array}{l}\text { i) Conselhos de administração mais } \\
\text { independentes unicamente adicionam valor em } \\
\text { indústrias menos competitivas; e } \\
\text { ii) umalto grau de independência de consellhos } \\
\text { de firmas que operamem ambientes comalta } \\
\text { competição ou competição moderada está } \\
\text { relacionada com menor valor da fima. }\end{array}$ \\
\hline Bozec (2005) & $\begin{array}{l}\text { Boards of } \\
\text { Directors, } \\
\text { Market } \\
\text { Discipline and } \\
\text { Firm } \\
\text { Performance }\end{array}$ & $\begin{array}{l}\text { Conselho de } \\
\text { Administração }\end{array}$ & $\begin{array}{l}\text { Oestudo investiga a interacãa entre as } \\
\text { características do conselho de } \\
\text { administração e disciplina de mercado } \\
\text { sobre o desenpenho da companhia. }\end{array}$ & $\begin{array}{l}\text { Canadá } \\
25 \text { estatais } \\
1976-2000\end{array}$ & $\begin{array}{l}\text { Relatórios anuais das } \\
\text { companhias. }\end{array}$ & $\begin{array}{l}\text { Regressão em cross- } \\
\text { section estimada por } \\
\text { OLS. }\end{array}$ & 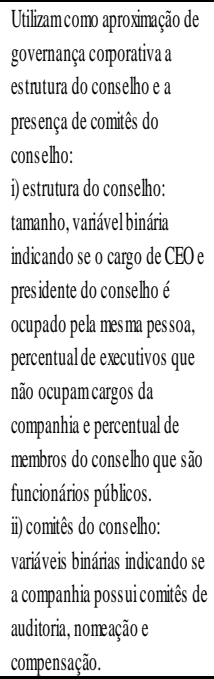 & $\begin{array}{l}\text { Variável binária indicando se } \\
\text { a companhia estatal é um } \\
\text { monopóilio ou se a } \\
\text { companhia possui } \\
\text { concorrentes no mercado. } \\
\end{array}$ & $\begin{array}{l}\text { i) Competição no mercado de produtos impacta } \\
\text { positivamente o desempenho da firma; } \\
\text { ii) competição propicia condições para que o } \\
\text { e efeito do conselho de administração sobre o } \\
\text { desempenho seja identificado; } \\
\text { iii) independênncia do consestho de adminstraçãa } \\
\text { é relacionado com desempenho negativo e baixa } \\
\text { produtividade quando as companhias estatais } \\
\text { são submetidas a alta competição; e } \\
\text { iv) os comitês do conselho não apresentaram } \\
\text { relação como desempenho da companhia. }\end{array}$ \\
\hline $\begin{array}{l}\text { Januszewski et } \\
\text { al. (2001) }\end{array}$ & $\begin{array}{l}\text { Product Market } \\
\text { Competition, } \\
\text { Corporate } \\
\text { Covernance and } \\
\text { Firm } \\
\text { Performance: } \\
\text { An Empirical } \\
\text { Analysis for } \\
\text { Cermany }\end{array}$ & $\begin{array}{l}\text { Desempenho, } \\
\text { competiçăoe } \\
\text { governança }\end{array}$ & $\begin{array}{l}\text { Investiga a efeito da competição no } \\
\text { mercado de produtos e estrutura de } \\
\text { propriedade sobre a produtuividade total } \\
\text { dos fatores. }\end{array}$ & $\begin{array}{l}\text { Alemanha } \\
491 \text { companhias } \\
1986-1994\end{array}$ & $\begin{array}{l}\text { Hoppenstedt's Balamce } \\
\text { Sheet Database (BSD) }\end{array}$ & $\begin{array}{l}\text { Método dos } \\
\text { Momentos } \\
\text { Generalizados } \\
\text { (ARELLANO; BOND; } \\
\text { 1991). }\end{array}$ & $\begin{array}{l}\text { A principal varíável utilizada } \\
\text { para mensurara govemança } \\
\text { corporativa é umindicador que } \\
\text { mostra se a firma possui um } \\
\text { áltimo controlador ou não, } \\
\text { considerando as conplexas } \\
\text { estuturas piramidais em } \\
\text { grandes firmas alemãs. }\end{array}$ & $\begin{array}{l}\text { i) Renda econômica; } \\
\text { ii) HHI; } \\
\text { iii) CR6; e } \\
\text { iv) taxa de penetração das } \\
\text { importações. }\end{array}$ & 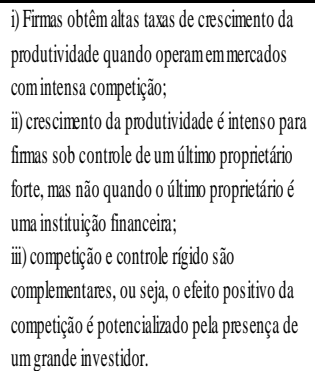 \\
\hline
\end{tabular}


Quadro 2- Resumo dos principais estudos analisados (continuação)

\begin{tabular}{|c|c|c|c|c|c|c|c|c|}
\hline Autor (es) & Categoria & Questão de pesquisarrelaçã̃o estudada & $\begin{array}{l}\text { País(es)/ Amostral } \\
\text { Período }\end{array}$ & $\begin{array}{l}\text { Base(s) de dados } \\
\text { principal(is) }\end{array}$ & $\begin{array}{l}\text { Técnica (s) } \\
\text { econométrica(s) } \\
\text { principal (is) }\end{array}$ & $\begin{array}{l}\text { Proxy de governança } \\
\text { corporatilia }\end{array}$ & $\begin{array}{l}\text { Proxy de competiçã̃o no } \\
\text { mercado de produtos }\end{array}$ & Principal(is) resultado(s) \\
\hline $\begin{array}{l}\text { Koke e } \\
\text { Renneboog } \\
\text { (2003) }\end{array}$ & $\begin{array}{l}\text { Desempenho, } \\
\text { competiçãoe } \\
\text { governança }\end{array}$ & $\begin{array}{l}\text { Investiga } 0 \text { impacto da competição no } \\
\text { mercado de produtos e govermança } \\
\text { corporativa sobre o crescimento da } \\
\text { produtividade total dos fatores para } \\
\text { duas amostras de companhias da } \\
\text { Alemanha e do Reino Unido. }\end{array}$ & $\begin{array}{l}\text { Alemanha } \\
\text { 1.074 companhias } \\
1986-1996 \\
\text { Reino Unido } \\
\text { 502 companhias } \\
\text { 1992-1999 }\end{array}$ & $\begin{array}{l}\text { i) Alemanha: } \\
\text { Hoppenstedt's e } \\
\text { Hypobank's; } \\
\text { ii) Reino Unido: Thomson } \\
\text { Financial Datastream, } \\
\text { Worldscope Disclosure, } \\
\text { London Stock Exhangee } \\
\text { Institutional Investors } \\
\text { Annual Guides. }\end{array}$ & $\begin{array}{l}\text { Método dos } \\
\text { Momentos } \\
\text { Ceneralizados } \\
\text { (ARELLANO; BOND; } \\
\text { 1991). }\end{array}$ & $\begin{array}{l}\text { i) a estrututurara de propriedade } \\
\text { da companhia, especificamente } \\
\text { a concentração do controle } \\
\text { acionário; } \text { e } \\
\text { ii) a estrutura de capital das } \\
\text { companhias. }\end{array}$ & Renda econômica. & $\begin{array}{l}\text { O principal resultado do estudo é que } \\
\text { govermança corporativa e competição no } \\
\text { mercado de produtos afetam significativamente } \\
\text { o aumento da produtividade das companhias, } \\
\text { contudo o resultado varia entre Alemanha e } \\
\text { Reino Unido, sendo que o papel do bloco de } \\
\text { controle e do banco credoré particularmente } \\
\text { importante em firmas com fraco desempenho. }\end{array}$ \\
\hline Lie Niu (2006) & $\begin{array}{l}\text { Desempenho, } \\
\text { competição e } \\
\text { governança }\end{array}$ & $\begin{array}{l}\text { Estuda } 0 \text { impacto da interação entre } \\
\text { governança corporativa e competição } \\
\text { no mercado de produtos sobre a } \\
\text { produtividade das companhias } \\
\text { chinesas. }\end{array}$ & $\begin{array}{l}\text { China } \\
3.822 \text { companhias } \\
1998-2003\end{array}$ & $\begin{array}{l}\text { i) CSMAR; e } \\
\text { ii) relatórín anual das } \\
\text { companhias. }\end{array}$ & $\begin{array}{l}\text { Método dos } \\
\text { Momentos } \\
\text { Ceneralizados } \\
\text { (ARELLANO; BOND; } \\
\text { 1991). }\end{array}$ & $\begin{array}{l}\text { i) estrutura de propriedade; } \\
\text { ii) composição do conselho de } \\
\text { administraçãa); e } \\
\text { iii) remuneração dos } \\
\text { executivos. }\end{array}$ & Renda econômica. & $\begin{array}{l}\text { i) Interaçãa entre concentração de propriedade } \\
\text { moderada e competiçãoo no mercado de } \\
\text { produtos sobre a produtividadeé } \\
\text { complementar, o mesmo ocorre entre } \\
\text { concentração relativamente dispersa e } \\
\text { competição; } \\
\text { ii) relação de substituição entre conselhos de } \\
\text { administraçãa e produtividade; e } \\
\text { iii) remuneração anual dos gestores possui } \\
\text { relaçãa complementar com competição. }\end{array}$ \\
\hline $\begin{array}{l}\text { Pattanayak } \\
\text { (2008) }\end{array}$ & $\begin{array}{l}\text { Desempenho, } \\
\text { competição e } \\
\text { governança }\end{array}$ & $\begin{array}{l}\text { Testa } 0 \text { efeito da interação entre } \\
\text { competição no mercado de produtos e } \\
\text { governança corporativa sobre } 0 \\
\text { desempenho da firma. }\end{array}$ & $\begin{array}{l}\text { Índia } \\
1.660 \text { companhias } \\
\text { i) } 2000-2001 \\
\text { ii) } 2003-2004\end{array}$ & PROWESS & $\begin{array}{l}\text { Dados empainel } \\
\text { utilizando a técnica de } \\
\text { efeitos fixos. }\end{array}$ & $\begin{array}{l}\text { i) estrutura de propriedade; e } \\
\text { ii) estrutua de capital. }\end{array}$ & $\begin{array}{l}\text { i) CR4; } \\
\text { ii) HHI; } \\
\text { iii) renda econônica;e } \\
\text { iv) participaçãao de mercado. }\end{array}$ & $\begin{array}{l}\text { i) Firmas comações concentradas sob a } \\
\text { propriedade de fammilias fundadoras são mais } \\
\text { produtivas unicamente quando submetidas a } \\
\text { uma intensa competição no mercado de } \\
\text { produtos;e } \\
\text { ii) a disciplina por meio de dívida tende a ter um } \\
\text { efeito negativo sobre a produtividade da } \\
\text { companhia. }\end{array}$ \\
\hline $\begin{array}{l}\text { Grosfeld e } \\
\text { Tressel(2001) }\end{array}$ & $\begin{array}{l}\text { Desempenho, } \\
\text { competição e } \\
\text { governança }\end{array}$ & $\begin{array}{l}\text { Ins vestiga o impacto da competição e } \\
\text { governança corporativa sobre } 0 \\
\text { desempenho da firma e se o efeito é de } \\
\text { substituição ou complementaridade. }\end{array}$ & $\begin{array}{l}\text { Polônia } \\
200 \text { companhias } \\
1991-1998\end{array}$ & $\begin{array}{l}\text { Dados públicos obtidos } \\
\text { principalmente em } \\
\text { demonstraçōes contábeis. }\end{array}$ & $\begin{array}{l}\text { Método dos } \\
\text { Momentos } \\
\text { Ceneralizados } \\
\text { (ARELLANO; BOND; } \\
\text { 1991;1998). }\end{array}$ & $\begin{array}{l}\text { Grau da concentração da } \\
\text { estrutura de propriedade. }\end{array}$ & $\begin{array}{l}\text { i) participação de mercado; } \\
\text { ii) renda econômica. }\end{array}$ & $\begin{array}{l}\text { i) Competição influencia positivamente } 0 \\
\text { crescimento da produtividade; } \\
\text { ii) } 0 \text { impacto da competição depende da } \\
\text { estrutura de propriedade da firma considerada, } \\
\text { pois competição tem impacto significativo em } \\
\text { firmas comestrutura relativamente dispersa ou } \\
\text { em firmas com estrutura de propriedade } \\
\text { altamente concentrada. }\end{array}$ \\
\hline
\end{tabular}


Quadro 2-Resumo dos principais estudos analisados (continuação)

\begin{tabular}{|c|c|c|c|c|c|c|c|c|}
\hline Autor (es) & Categoria & Questão de pesquisa/relação estudada & $\begin{array}{l}\text { País (es)/ Amostral } \\
\text { Período }\end{array}$ & $\begin{array}{l}\text { Base(s) de dados } \\
\text { principal(is) }\end{array}$ & $\begin{array}{l}\text { Técnica (s) } \\
\text { econométrica(s) } \\
\text { principal (is) }\end{array}$ & $\begin{array}{l}\text { Proxy de governança } \\
\text { corporativa }\end{array}$ & $\begin{array}{l}\text { Proxy de competiçãono no } \\
\text { mercado de produtos }\end{array}$ & Principal(is) resultado(s) \\
\hline Girffith (2001) & $\begin{array}{l}\text { Desempenho, } \\
\text { competição e } \\
\text { governança }\end{array}$ & $\begin{array}{l}\text { Investiga se umaumento da } \\
\text { competição no mercado de produtos } \\
\text { temimpacto nos níveis de } \\
\text { produtividade e taxa de crescimento, se } \\
\text { esse efeito é positivo ou negativivo, ese } \\
0 \text { aumento da competição leva a uma } \\
\text { mudança nos níveis de produtividade } \\
\text { por meio da reducãão dos custos de } \\
\text { agência. }\end{array}$ & $\begin{array}{l}\text { Reino Unido } \\
103.443 \text { observaçōes } \\
1980-1996\end{array}$ & $\begin{array}{l}\text { Anual Census of } \\
\text { Production (ACOP) } \\
\text { Respondents Database } \\
\text { (ARD). }\end{array}$ & $\begin{array}{l}\text { Diferenças-em- } \\
\text { differenças. }\end{array}$ & $\begin{array}{l}\text { Separação dos } \\
\text { estabelecimentos da pesquisa } \\
\text { emquatro diferentes grupos, a } \\
\text { fimde identificar os que } \\
\text { possuemmais chance de } \\
\text { ocorrer problema agente } \\
\text { principal: } \\
\text { i) estabelecimento administrado } \\
\text { pelo proprietário; } \\
\text { ii) estabelecimento com } \\
\text { subsidiárias; } \\
\text { iii) estabelecimentos } \\
\text { admnistrados pelo poder } \\
\text { público; e } \\
\text { iv) outros. }\end{array}$ & Índice de Lemer & $\begin{array}{l}\text { Os resultados sugerem que umaumento da } \\
\text { competição no mercado de produtos está } \\
\text { associada a umaumento da produtividade das } \\
\text { companhias, sendo que os aumentos não foram } \\
\text { constatados emfirmas que não havia } \\
\text { previamente umpotencial para o problema } \\
\text { agente-principal, mas sim naquelas que havia. }\end{array}$ \\
\hline $\begin{array}{l}\text { Giroude } \\
\text { Mueller (2009) }\end{array}$ & $\begin{array}{l}\text { Desempenho, } \\
\text { competição e } \\
\text { governança }\end{array}$ & $\begin{array}{l}\text { Estuda se a competição mitiga o } \\
\text { des leixo gerencial utilizando variações } \\
\text { exógenas de governança corporativa } \\
\text { por mio de } 30 \text { leis sobre combinação } \\
\text { de negócios, aprovadas entre } 1985 \text { e } \\
\text { 1991. }\end{array}$ & $\begin{array}{l}\text { EUA } \\
10.960 \text { companhias } \\
1976-1995\end{array}$ & $\begin{array}{l}\text { Standard and Poor's } \\
\text { Compustat. }\end{array}$ & $\begin{array}{l}\text { Diferenças-em- } \\
\text { diferenças-em- } \\
\text { diferenças. }\end{array}$ & $\begin{array}{l}\text { No estudo, mudanças nas leis } \\
\text { de combinação de negócios } \\
\text { são utilizadas como uma } \\
\text { aproximação de governança } \\
\text { corporativa. Nos testes de } \\
\text { robustez, } 0 \text { "G-index" e } 0 \text { "E- } \\
\text { index" tambémsão utilizados } \\
\text { para aproximara qualidade de } \\
\text { govermança corporativa. }\end{array}$ & HHI & $\begin{array}{l}\text { Emresumo, os resultados do estudo indicam } \\
\text { que firmas operando emmercados menos } \\
\text { competitivos experimentamuma significicante } \\
\text { retração em seu desempenho operacional após } \\
\text { a mudança das leis, enquanto que firmas } \\
\text { operando em mercados mais competitivos } \\
\text { vitualmente não sofreram quaisquer efeitos, } \\
\text { cujo achado é consistente coma idéia de que } \\
\text { conpetiçãa mitiga o desleixo gerencial. }\end{array}$ \\
\hline $\begin{array}{l}\text { Kole e Lehn } \\
\text { (1999) }\end{array}$ & $\begin{array}{l}\text { Desregulamen- } \\
\text { tação de setores }\end{array}$ & $\begin{array}{l}\text { Investiga a evolução da estrutura de } \\
\text { governança corporativa, caracterizada } \\
\text { pela concentração de propriedade, } \\
\text { politicas de remuneração e composição } \\
\text { do conselho de administração, no } \\
\text { indústria aérea americana durante } 22 \\
\text { anos emtorno da lei que } \\
\text { des regulamentou o setor, em } 1978 .\end{array}$ & $\begin{array}{l}\text { EUA } \\
21 \text { companhias } \\
1971-1992\end{array}$ & $\begin{array}{l}\text { i) CRSP; e } \\
\text { ii)Compustat. }\end{array}$ & $\begin{array}{l}\text { i) Regressão em cross- } \\
\text { section estimada por } \\
\text { OLS; } e \\
\text { ii)Painel utilizando a } \\
\text { técnica de efeitos } \\
\text { fixos. }\end{array}$ & $\begin{array}{l}\text { i) estrutura de propriedade; } \\
\text { ii) remuneração dos } \\
\text { executivos; e } \\
\text { iii) estrutura do conselho de } \\
\text { administraçã̃o. }\end{array}$ & $\begin{array}{l}\text { A própria } \\
\text { destregulamentação do setor } \\
\text { é utilizada como um } \\
\text { experimento para medir } 0 \\
\text { aumento da competição no } \\
\text { mercado de produtos. }\end{array}$ & 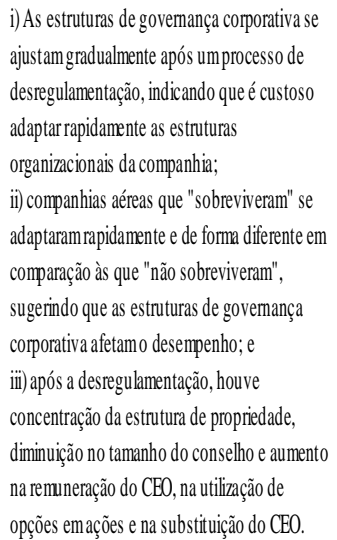 \\
\hline
\end{tabular}


Quadro2 - Resumo dos principais estuddos analisados (continuacão)

\begin{tabular}{|c|c|c|c|c|c|c|c|c|}
\hline Autor (es) & Categoria & Questão de pesquisarelaç̧ã̃o estudada & $\begin{array}{l}\text { Paísess)/Amostra/ } \\
\text { Período }\end{array}$ & $\begin{array}{l}\text { Base(s) de dados } \\
\text { principal (is) }\end{array}$ & $\begin{array}{l}\text { Técnica (s) } \\
\text { econométrica(s) } \\
\text { principal (is) }\end{array}$ & $\begin{array}{l}\text { Proxy de governança } \\
\text { corporativia }\end{array}$ & $\begin{array}{l}\text { Proxy de competição no } \\
\text { mercado de produtos }\end{array}$ & Principal(is) resultadob(s) \\
\hline Rennie (2006) & $\begin{array}{l}\text { Desregulamen- } \\
\text { tação de setores }\end{array}$ & $\begin{array}{l}\text { Estuda quais foram as mudanças nas } \\
\text { estruturas de governança corporativa } \\
\text { das companhhias de energia elétrica } \\
\text { após a desregulamentaçãao e explora a } \\
\text { relação entre a competição no mercado } \\
\text { de produtos a mudança nas } \\
\text { estruturas de governança corporativa. }\end{array}$ & $\begin{array}{l}\text { EUA } \\
101 \text { companhias } \\
\text { i) } 1987-1990 \\
\text { ii) } 1994-1997\end{array}$ & $\begin{array}{l}\text { i) CRSP; } \\
\text { ii) Compustat; e } \\
\text { iii) relatório } Q \text {. }\end{array}$ & $\begin{array}{l}\text { i) Painel utilizando a } \\
\text { técnica de efeitos } \\
\text { fixos; } \text { e } \\
\text { ii) Análise Fatorial. }\end{array}$ & 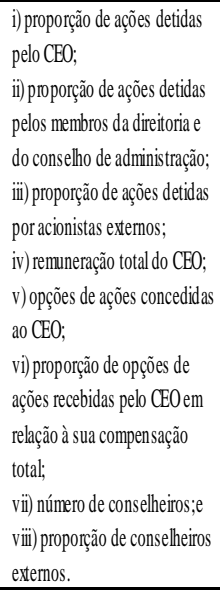 & $\begin{array}{l}\text { Utiliza a desregulamentação } \\
\text { do setor elétrico } \\
\text { estadunidense como um } \\
\text { experimento natural de como } \\
\text { a alteração da competição no } \\
\text { mercado de produtos pode } \\
\text { alterar as estruturas de } \\
\text { governança corporativa das } \\
\text { companhias. } 0 \text { HHIé } \\
\text { utilizzado para mensurara a } \\
\text { possível alteração no nível } \\
\text { de competição. }\end{array}$ & 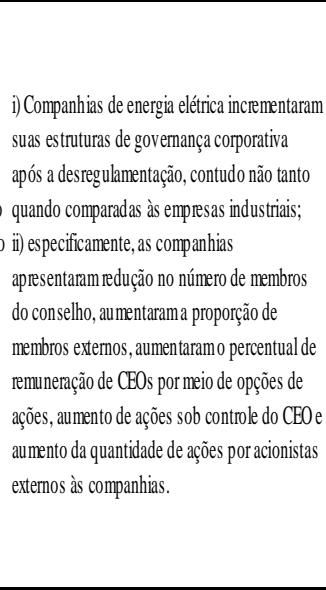 \\
\hline Shin (2002) & $\begin{array}{l}\text { Divulgação de } \\
\text { informaçōes }\end{array}$ & $\begin{array}{l}\text { Investiga a associaçãa entre } \\
\text { competição no merado de produtos e } \\
\text { niveis de disclosure voluntário de } \\
\text { informaçōes corporativas. }\end{array}$ & $\begin{array}{l}\text { EUA } \\
416 \text { companhias } 1987 . \\
1995\end{array}$ & $\begin{array}{l}\text { Association for } \\
\text { Investment and } \\
\text { Management Research } \\
\text { (AIMR). }\end{array}$ & $\begin{array}{l}\text { Regressão em cross- } \\
\text { section estimada por } \\
\text { OLS. }\end{array}$ & $\begin{array}{l}\text { Nível de disclosure voluntário } \\
\text { extraído da base dados da } \\
\text { AIMR. }\end{array}$ & $\begin{array}{l}\text { i) interações estratégicas } \\
\text { entre as fimas ; } e \\
\text { ii) medida de probabilidade } \\
\text { de concorrência. }\end{array}$ & $\begin{array}{l}\text { Firmas submetidas a competição de capacidade } \\
\text { evidenciam maior quantidade de informações do } \\
\text { que firmas submetidas a competição de preços. }\end{array}$ \\
\hline Li(2010) & $\begin{array}{l}\text { Divulgação de } \\
\text { informaçỗes }\end{array}$ & $\begin{array}{l}\text { Estuda como a divulgação voluntária } \\
\text { das companhias é ínfluenciada pela } \\
\text { competição no merado de produtos. }\end{array}$ & $\begin{array}{l}\text { EUA } \\
\text { 27.053 indústrias-ano } \\
\text { 1977-2007 }\end{array}$ & $\begin{array}{l}\text { i) Compustat; } \\
\text { ii) I/B/ES/ } \\
\text { iii) First Call; e } \\
\text { iv) Factiva Search Engine. }\end{array}$ & $\begin{array}{l}\text { i) Análise fatorial; } \\
\text { ii) Regressão em cross- } \\
\text { section estimada por } \\
\text { OLS; }\end{array}$ & $\begin{array}{l}\text { Divulgação de previsõos dos } \\
\text { gestores sobre os lucros e } \\
\text { investimentos esperados. }\end{array}$ & $\begin{array}{l}\text { i) valor ponderado das } \\
\text { propriedades, plantas e } \\
\text { equipamentos; } \\
\text { ii) valor ponderado dos } \\
\text { investimentos em pesquisae } \\
\text { desenvolvimento; } \\
\text { iii) valor ponderado do } \\
\text { investimento total da firma; } \\
\text { iv) tamanho do mercado; } \\
\text { v) C4; } \\
\text { vi) HHI; } \\
\text { vii) número de firmas; } \\
\text { viii) margempreço-custo;e } \\
\text { ii) retorno sobre o ativo. }\end{array}$ & $\begin{array}{l}\text { A autora encontra que a competição } \\
\text { proveniente dos potenciais entrantes aumenta o } 0 \\
\text { a quantidade de disclosure enquanto que a } \\
\text { e competição advinda dos rivais existentes reduz } \\
\text { a quantidade de disclosure. Ademais, a autora } \\
\text { também encontra que até determinado nivel de } \\
\text { incentivo do mercado de capitais, competição } \\
\text { aumenta a qualidade do disclosure. Assim, de } \\
\text { forma geral, a pesquisa indica que a competição } \\
\text { no mercado de produtos é uma varível } \\
\text { impottante para explicar o disclosure voluntárí } \\
\text { por parte das companhias. }\end{array}$ \\
\hline
\end{tabular}

i) Os resultados dos testes estatísticos mostram que a grau de substitutibilidade dos produtos $\mathrm{e}$ o tamanho do mercado se relacionam positivamente comos incentivos, enquanto os custos de entrada se relacionamnegativamente,

Incentivos Investiga o efeito da competição no EUA $\quad$ i) CRSP;

Karuna (2007) concedidos aos mercado de produtos sobre os 1.579 companhias ii) Compustat; e gestores incentivos concedidos aos gestores. 1992-2003 iiilExecucomp. i) Regressão em crosssection estimada por Incentivos concedidos aos i) Grau de substitutibilidad OLS; e gestores, mensurados por meio dos produtos; ii) Painel utilizando a do valor total de ações e $\quad$ ii) tamanho do mercado técnica de efeitos opções em ações concedidas $\quad$ iii) custos de entrada; $e$ aos gestores. iv) CR4 assim conclui-se que companhias provêmseus gestores com grandes incentivos quando a competição na indústria é intensa;e ii) evidências sugeremrelação ambígua entre incentivos e grau de concentração, cuja implicação éa necessidade de cuidados por parte de pesquisadores que utilizam apenas uma métrica de concentraçáa como aproximação para a competição. 
Quadro 2 - Resumo dos principais estudos analisados (continuacão)

\begin{tabular}{|c|c|c|c|c|c|c|c|c|}
\hline Autor (es) & Categoria & Questão de pesquisa/relação estudada & $\begin{array}{l}\text { Páisess)/Amostral } \\
\text { Período }\end{array}$ & $\begin{array}{l}\text { Base(s) de dados } \\
\text { principal(is) }\end{array}$ & $\begin{array}{l}\text { Técnica (s) } \\
\text { econométrica(s) } \\
\text { principal (is) }\end{array}$ & $\begin{array}{l}\text { Proxy de governança } \\
\text { corporatilia }\end{array}$ & $\begin{array}{l}\text { Proxy de competição no } \\
\text { mercado de produtos }\end{array}$ & Principal(is) resultado(s) \\
\hline $\begin{array}{l}\text { Cuñat e } \\
\text { Guadalupe } \\
\text { (2004) }\end{array}$ & $\begin{array}{l}\text { Incentivos } \\
\text { concedidos aos } \\
\text { gestores }\end{array}$ & $\begin{array}{l}\text { Estuda os efeitos da competição no } \\
\text { mercado de produtos sobre o pacote de } \\
\text { remuneraçãa oferecido aos gestores. }\end{array}$ & $\begin{array}{l}\text { EUA } \\
\text { e 22.000 observações } \\
1992-2000\end{array}$ & $\begin{array}{l}\text { i) Standard\&Poor's } \\
\text { Execucomp dataset; e } \\
\text { ii) US Census. }\end{array}$ & $\begin{array}{l}\text { i) Regressão em cross- } \\
\text { section estimada por } \\
\text { OLS; } \mathrm{e} \\
\text { ii) Diferenças-em- } \\
\text { diferenças. }\end{array}$ & $\begin{array}{l}\text { i) remuneraçãa do executivo } \\
\text { durante o ano; } \\
\text { ii) remuneração do executivo } \\
\text { somada a eventuais bônus;ę } \\
\text { iii) valor das opções } \\
\text { concedidas, calculado pelo } \\
\text { modelo de Black-Scholes. } \\
\end{array}$ & $\begin{array}{l}\text { i) CR4; e } \\
\text { ii) umexperimento valendo- } \\
\text { se de duas } \\
\text { desregulamentações } \\
\text { ocorridas no setor bancário } \\
\text { e financeiro. }\end{array}$ & $\begin{array}{l}\text { Em resumo, os resultados indicam que o efeito } \\
\text { da competição no mercado de produtos é } \\
\text { aumentar a sensibilidade do pagamento por } \\
\text { desempenho, indicando que quando a } \\
\text { competição aumenta, os gestores são } \\
\text { colocados frente a um aumento nos incentivos. }\end{array}$ \\
\hline $\begin{array}{l}\text { Cuñate } \\
\text { Guadalupe } \\
\text { (2005) }\end{array}$ & $\begin{array}{l}\text { Incentivos } \\
\text { concedidos aos } \\
\text { gestores }\end{array}$ & $\begin{array}{l}\text { Mensura como os pagamentos } \\
\text { baseados em desempenho variam para } \\
\text { o principal executivo, demais diretores e } \\
\text { trabalhadores após mudanças da } \\
\text { competição no mercado de produtos. }\end{array}$ & $\begin{array}{l}\text { Reino Unido } \\
\text { e 22.183 observaçôes } \\
1992-2000\end{array}$ & FAME-BVD. & $\begin{array}{l}\text { Diferenças-em- } \\
\text { diferenças. }\end{array}$ & $\begin{array}{l}\text { Dados sobre a remuneração } \\
\text { total auferida pelo principal } \\
\text { executivo e demais executivos } \\
\text { e trabalhadores da firma. }\end{array}$ & $\begin{array}{l}\text { A alta e inesperada } \\
\text { apreciaçăo da libra esterlina } \\
\text { em } 1996 \text { foi utilizada como } \\
\text { uma forma de identificar } \\
\text { impactos no nível de } \\
\text { competição no mercado de } \\
\text { produtos, dependendo de } \\
\text { quanto exposta ao comércio } \\
\text { exterior estava a firma. }\end{array}$ & $\begin{array}{l}\text { Os resultado indicam que setores mais } \\
\text { expostos à competição externa aumentaramo } \\
\text { nível de remuneração atrelada ao desenpenho } \\
\text { após a apreciação cambial comparativamente } \\
\text { mais do que setores menos expostos à } \\
\text { competição exterma. }\end{array}$ \\
\hline $\begin{array}{l}\text { Kadyrhanova e } \\
\text { Rhodes-Kropf } \\
(2007)\end{array}$ & $\begin{array}{l}\text { Medidas } \\
\text { antitakeover }\end{array}$ & $\begin{array}{l}\text { Investiga se os efeitos de medidas } \\
\text { antitakeover sobre o valor das } \\
\text { companhias variam em função do grau } \\
\text { de concentração da indústria. }\end{array}$ & $\begin{array}{l}\text { EUA } \\
1.500 \text { companhias } \\
1990-2005\end{array}$ & $\begin{array}{l}\text { i) Compustat; } \\
\text { ii) CRSP; } \\
\text { iii) IRRC; } \\
\text { iv) Census Bureau; e } \\
\text { v) ExecuComp. }\end{array}$ & $\begin{array}{l}\text { i) Model probit; } \\
\text { ii) Regressão em cross- } \\
\text { section estimada por } \\
\text { OLS; e } \\
\text { iii) OLS em dois } \\
\text { estágios. }\end{array}$ & $\begin{array}{l}\text { i) ́ndice que capta a exitência } \\
\text { de um consellho de } \\
\text { administração qualficicado e } \\
\text { poison pills; } \\
\text {-ii) "G-index" desenvolvido por } \\
\text { Gompers et al. (2003); } \\
\text { iii)" "E-index" desenvolvido por } \\
\text { Bebchuck et al. (2005); } \\
\text { iv) posse de ações por parte de } \\
\text { investidores institucionais, } \\
\text { fundos de pensão e agentes } \\
\text { internos à companhia. }\end{array}$ & $\begin{array}{l}\text { i) HHF; } \\
\text { ii) CR4; } \\
\text { iii) taxa de penetração das } \\
\text { importações; e } \\
\text { iv) número de competidores. }\end{array}$ & $\begin{array}{l}\text { i) Firmas emindústrias mais concentradas } \\
\text { tendema adotar mais cláusulas antitakeover, } \\
\text { ii) cláusulas antitakeover são associadas com } \\
\text { atto valor da firma, mas apenas emindústrias } \\
\text { concentradas; e } \\
\text { iii)em indústrias menos concentradas, clásulas } \\
\text { antitakeover estão ligadas à destruição de valor } \\
\text { da companhia. }\end{array}$ \\
\hline $\begin{array}{l}\text { Cremers etal. } \\
\text { (2008) }\end{array}$ & $\begin{array}{l}\text { Medidas } \\
\text { antitakeover }\end{array}$ & $\begin{array}{l}\text { Investiga como a competição no } \\
\text { mercado de produtos interage como } \\
\text { mercado de controle corporativo e se } \\
\text { ambientes competitivos afetamo } \\
\text { número de medidas antitakeover } \\
\text { utilizadas pelas enpresas. }\end{array}$ & $\begin{array}{l}\text { EUA } \\
873 \text { observações } \\
1990-2003\end{array}$ & $\begin{array}{l}\text { i) IRRC; } \\
\text { ii) Compustat;e } \\
\text { iii) Economic Census. }\end{array}$ & $\begin{array}{l}\text { i) Regressão em cross- } \\
\text { section estimada por } \\
\text { OLS; } ~ \\
\text { ii) Painel utilizando a } \\
\text { técnica de efétos } \\
\text { fixos. }\end{array}$ & $\begin{array}{l}\text { i) "G-index" desenvolvido por } \\
\text { Gompers et al. (2003); } \\
\text { ii) "E-index" desenvolvido por } \\
\text { Bebchuck et al. (2005); } \\
\text { iii) "ATI-index", desenvolvido } \\
\text { porCremers and Nair (2005). }\end{array}$ & $\begin{array}{l}\text { i) margem de lucro mediana } \\
\text { da indústria:e } \\
\text { ii) HHI. }\end{array}$ & $\begin{array}{l}\text { i) os resultados dos testes estatísticos indicam } \\
\text { que mais competição é as sociada com mais } \\
\text { defesas antitakeover,e } \\
\text { ii) para firmas emindústrias que as relações com } \\
\text { clientes e fornecedores tendema ser mais } \\
\text { próximm, o estudo aponta que forte competição } \\
\text { está relacionada com maior quantidade de } \\
\text { cláusulas antitakeover. }\end{array}$ \\
\hline $\begin{array}{l}\text { Grullon e } \\
\text { Michaely (2006) }\end{array}$ & $\begin{array}{l}\text { Políticas de } \\
\text { distribuição de } \\
\text { dividendos }\end{array}$ & $\begin{array}{l}\text { Investiga se a relação entre competição } \\
\text { no mercado de produtos e incentivos } \\
\text { aos gestores temalguma implicação } \\
\text { sobre a política de distribuiçãa de } \\
\text { dividendos das companhias. }\end{array}$ & $\begin{array}{l}\text { EUA } \\
3.011 \text { companhias } \\
1972-2001\end{array}$ & $\begin{array}{l}\text { i) Compustat; } \\
\text { ii) CRSP; } \mathrm{e} \\
\text { iii) Economic Census. }\end{array}$ & Modelo Tobit & $\begin{array}{l}\text { Foramutilizadas métricas com } 0 \\
\text { intuito de identificar o total de } \\
\text { remuneração dos acionistas em } \\
\text { relação às vendas, total de } \\
\text { ativos e valor de mercado das } \\
\text { ações da companhia. }\end{array}$ & & $\begin{array}{l}\text { i) distribuiçã̃o de dividendos é negativamente } \\
\text { correlacionada como nível de concentração da } \\
\text { indústria; } \\
\text { ii) o efeito da competição no mercado de } \\
\text { produtos sobre a remuneração aos acionistas é } \\
\text { relevante entre as firmas que são mais } \\
\text { propensas a super investir recursos. }\end{array}$ \\
\hline
\end{tabular}


Quadro 2- Resumo dos principais estudos analisados (continuação)

\begin{tabular}{|c|c|c|c|c|c|c|c|c|}
\hline Autor (es) & Categoria & Questão de pesquisa/relação estudada & $\begin{array}{l}\text { País(es)/ Amostral } \\
\text { Período }\end{array}$ & $\begin{array}{l}\text { Base(s) de dados } \\
\text { principal(is) }\end{array}$ & $\begin{array}{l}\text { Técnica (s) } \\
\text { econométrica(s) } \\
\text { principal (is) }\end{array}$ & $\begin{array}{l}\text { Proxy de governança } \\
\text { corporativa }\end{array}$ & $\begin{array}{l}\text { Proxy de competição no } \\
\text { mercado de produtos }\end{array}$ & Principal(is) resultado(s) \\
\hline $\begin{array}{l}\text { Chou et al. } \\
\text { (2008) }\end{array}$ & $\begin{array}{l}\text { Qualidade de } \\
\text { governança } \\
\text { corporativae } \\
\text { competição }\end{array}$ & $\begin{array}{l}\text { Investiga se e como a natureza da } \\
\text { competição no mercado de produtos } \\
\text { age como um mecanismo externo de } \\
\text { disciplina dos gestores. }\end{array}$ & $\begin{array}{l}\text { EUA } \\
\text { Todas as companhias } \\
\text { listadas na NYSE, } \\
\text { AMEX NASDAQ } \\
\text { que possuíssem } \\
\text { informações } \\
\text { completas para 0 } \\
\text { perído analisado. } \\
\text { 1990-2005 }\end{array}$ & $\begin{array}{l}\text { i) IRRC; } \\
\text { ii) CRSP; e } \\
\text { iii)Compustat. }\end{array}$ & $\begin{array}{l}\text { i) Painel utilizando a } \\
\text { técnica de efétos } \\
\text { aleatórios; } \text {; } \\
\text { ii) Regressão de Fama- } \\
\text { MacBeth. }\end{array}$ & $\begin{array}{l}\text { i) "Gindex" desenvolvido por } \\
\text { Gompers et al. (2003); ; } \\
\text { ii)"E-index" desenvolvido por } \\
\text { Bebchuck et al. (2005). }\end{array}$ & $\begin{array}{l}\text { i) HHI; e } \\
\text { i) margem preço-custo } \\
\text { ajustada ao nível da } \\
\text { indústria. }\end{array}$ & $\begin{array}{l}\text { i) Competiç̃o age como um substituto para os } \\
\text { mecanismos de governança corporativa; } \\
\text { ii) firmas em mercados altamente competitivos } \\
\text { tendema ter governança corporativa } \\
\text { significativamente mais fraca em comparação à } \\
\text { governança de firmas que operamem mercados } \\
\text { menos competitivos; } \\
\text { iii) governança corporativa só tem umimpacto } \\
\text { significante sobre o desempenho quando a } \\
\text { competiçãoo é baixa. }\end{array}$ \\
\hline Karuna (2008) & $\begin{array}{l}\text { Qualidade de } \\
\text { governança } \\
\text { corporativae } \\
\text { competiição }\end{array}$ & $\begin{array}{l}\text { Investiga se a competição no mercado } \\
\text { de produtos é relevante na definição da } \\
\text { estrutura de governança corporativa } \\
\text { das firmas. }\end{array}$ & $\begin{array}{l}\text { EUA } \\
\text { i) } 1.206 \text { companhias; } \\
\text { ii) } 1.174 \text { companhias;e } \\
\text { iii) } 971 \text { companhias. } \\
1992-2003\end{array}$ & $\begin{array}{l}\text { i) IRRC; } \\
\text { e ii) CRSP; e } \\
\text { iii)Compustat. }\end{array}$ & $\begin{array}{l}\text { i) Regressão emcross- } \\
\text { section estimada por } \\
\text { OLS; e } \\
\text { ii) Painel utilizando a } \\
\text { técnica de efeitos } \\
\text { aleatórios. }\end{array}$ & $\begin{array}{l}\text { i) tamanho do conselho; } \\
\text { ii) percentual de conselheiros } \\
\text { independentes; } \\
\text { iii) "G-index" desenvolvido por } \\
\text { Gompers et al. (2003); e } \\
\text { iv) Índice de governança } \\
\text { considerando as três métricas } \\
\text { acima apresentadas. }\end{array}$ & $\begin{array}{l}\text { i) Crau de substitutibilidade } \\
\text { dos produtos; } \\
\text { ii) tamanho do mercado; } \\
\text { iii) custos de entrada; } \\
\text { iv) CR4 }\end{array}$ & $\begin{array}{l}\text { Emsíntese, a substitutibililidade dos produtos e } \\
\text { o tamanho do mercado temuma relação positiva } \\
\text { coma força da governança corporativa através } \\
\text { de diferentes mecanismos de governança } \\
\text { corporativa utilizados no estudo, enquanto os } \\
\text { custos de entrada possuem relação negativa. } \\
\text { Entretanto, a partiri de determinado nível de } \\
\text { competição, tal relação muda de sinal, indicando } \\
\text { um relação entre competição e governanç̧a em } \\
\text { forma de um "U" invertido. }\end{array}$ \\
\hline $\begin{array}{l}\text { DeFonde e Park } \\
\text { (1999) }\end{array}$ & $\begin{array}{l}\text { Substituição de } \\
\text { executivos }\end{array}$ & $\begin{array}{l}\text { Investiga se a substituição de diretores- } \\
\text { presidente é mais frequente em } \\
\text { indústrias mais competitivas e se a } \\
\text { frequência de substituç̧ão de diretores- } \\
\text { presidenteé mais diretamente } \\
\text { associada com medidas de desempenho } \\
\text { relativo, baseadas em métricas } \\
\text { contábeis, emindústrias com alta } \\
\text { competição do que em indústrias com } \\
\text { baixa competição. }\end{array}$ & $\begin{array}{l}- \\
\text { EUA } \\
301 \text { firmas } \\
1988-1992\end{array}$ & $\begin{array}{l}\text { i) Lexis/Nexis; } \\
\text { ii) CRSP; } \\
\text { iii) I/B/ES/ } \text {; e } \\
\text { iv) Compustat. }\end{array}$ & Regressão logística. & $\begin{array}{l}\text { Frequência de substituição do } \\
\text { diretor-presidente. }\end{array}$ & HHI & $\begin{array}{l}\text { i) Frequência de substituição dos diretores- } \\
\text { presidente é maior em indústrias mais } \\
\text { competitivas; } \\
\text { ii) avaliações relativas de desempenho por meio } \\
\text { de métricas contábeis são significativamente } \\
\text { associadas coma substituição do diretor- } \\
\text { presidente em indústrias competitivas, mas não } \\
\text { emindústrias com baixo grau de competição. }\end{array}$ \\
\hline $\begin{array}{l}\text { Giroude } \\
\text { Mueller (2008) }\end{array}$ & $\begin{array}{l}\text { Valor da firma, } \\
\text { competição e } \\
\text { governança }\end{array}$ & $\begin{array}{l}\text { Examina a hipótese de que firmas em } \\
\text { indústrias mais competitivas se } \\
\text { beneficiariariammenos de boas práticas } \\
\text { de govermança, enquanto firmas em } \\
\text { indústrias menos conpetitivas se } \\
\text { beneficiariammais. }\end{array}$ & $\begin{array}{l}\text { EUA } \\
3.241 \text { companhias } \\
\text { 1990-2006 }\end{array}$ & $\begin{array}{l}\text { i) IRRC; } \\
\text { ii) CRSP; e } \\
\text { iii)Compustat. }\end{array}$ & $\begin{array}{l}\text { i) Painel utilizando a } \\
\text { técnica de efétos } \\
\text { aleatórios; e } \\
\text { ii) Regressão de Fama- } \\
\text { MacBeth. }\end{array}$ & $\begin{array}{l}\text { i) "G-index" desenvolvido por } \\
\text { Gompers et al. (2003); e } \\
\text { ii) "E-index" desenvolvido por } \\
\text { Bebchuck et al. (2005). }\end{array}$ & $\mathrm{HHI}$ & $\begin{array}{l}\text { O efeito de práticas de governança corporativa } \\
\text { tiveram efeitos relevantes sobre as o retomo } \\
\text { das ações, valor da empresa e desempenho } \\
\text { operacional apenas em companhias que operam } \\
\text { em mercado menos competitivos. }\end{array}$ \\
\hline
\end{tabular}


Quadro 2- Resumo dos principais estudos analisados (continuação)

\begin{tabular}{|c|c|c|c|c|c|c|c|c|}
\hline Autor (es) & Categoria & Questão de pesquisa/relação estudada & $\begin{array}{l}\text { País (es)/Amostral } \\
\text { Período }\end{array}$ & $\begin{array}{l}\text { Base(s) de dados } \\
\text { principal(is) }\end{array}$ & $\begin{array}{l}\text { Técnica (s) } \\
\text { econométrica(s) } \\
\text { principal (is) }\end{array}$ & $\begin{array}{l}\text { Proxy de governança } \\
\text { corporatilia }\end{array}$ & $\begin{array}{l}\text { Proxy de competição no } \\
\text { mercado de produtos }\end{array}$ & Principal(is) resultado(s) \\
\hline $\begin{array}{l}\text { Anmann et } \\
\text { al. (2010) }\end{array}$ & $\begin{array}{l}\text { Valor da firma, } \\
\text { competição e } \\
\text { governança }\end{array}$ & $\begin{array}{l}\text { Estuda a relação entre competição no } \\
\text { mercado de produtos, governança } \\
\text { corporativa e valor da firma. }\end{array}$ & $\begin{array}{l}14 \text { páses europeus } \\
3.102 \text { firmas } \\
2003-2007\end{array}$ & $\begin{array}{l}\text { i) Thomson Financial } \\
\text { Worldscope; e } \\
\text { ii) Bureau van Dijk's } \\
\text { Amadeus. }\end{array}$ & $\begin{array}{l}\text { Painel utilizando a } \\
\text { técnica de efeitos } \\
\text { fixos. }\end{array}$ & $\begin{array}{l}64 \text { diferentes atributos obtidos } \\
\text { do índice elaborado pela } \\
\text { consultoria Governance } \\
\text { Metrics International (GMI), } \\
\text { que é dividido em } 6 \text { categorias. }\end{array}$ & $\mathrm{HHI}$ & $\begin{array}{l}\text { Os resultados principais do estudo indicam que } \\
\text { governançaé correlacionada de forma positiva } \\
\text { e signnificativa como valor da firma pertencentes } \\
\text { a setores menos competitivos. Assim, os } \\
\text { resultados são consistentes coma hipótese de } \\
\text { que competição no mercado de produtos atua } \\
\text { como um substituto às boas práticas de } \\
\text { governança corporativa. }\end{array}$ \\
\hline $\begin{array}{l}\text { Beiner et al. } \\
(2009)\end{array}$ & $\begin{array}{l}\text { Valor da firma, } \\
\text { competição e } \\
\text { governança }\end{array}$ & $\begin{array}{l}\text { Visa a investigar se os gestores } \\
\text { trabalham mais eficientemente quando } \\
\text { o ambiente no qual a firma opera é mais } \\
\text { competitivo. }\end{array}$ & $\begin{array}{l}\text { Suiça } \\
199-204 \text { firmas } \\
2002-2005\end{array}$ & $\begin{array}{l}\text { i) Bureau van Dijk's } \\
\text { Amadeus Database; } \\
\text { ii) Thomson Financialls } \\
\text { Datastreame } \\
\text { Worldscope; } \\
\text { iii) Finanz \& Wirtschaft:e } \\
\text { iv) Swiss Stock Guide. }\end{array}$ & $\begin{array}{l}\text { Painel utilizando a } \\
\text { técnica de efeitos } \\
\text { fixos. }\end{array}$ & 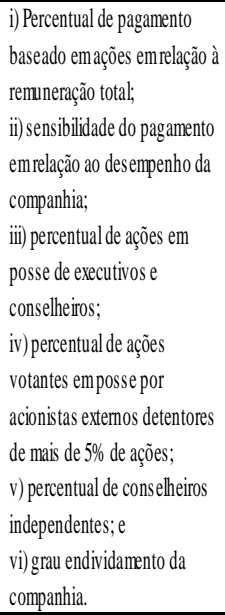 & $\begin{array}{l}\text { i) HHI; } \\
\text { ii) mediana da margem de } \\
\text { lucro líquido ao nível da } \\
\text { indústria ; } \mathrm{e} \\
\text { iii) renda econômica. }\end{array}$ & $\begin{array}{l}\text { i) Intensa competição no mercado de produtos } \\
\text { mensurada pelo HHI é ass ociada com fortes } \\
\text { esquemas de incentivos aos gestores } \\
\text { mensurado pela fração de pagamentos } \\
\text { realizados em ações e a sensbilidade do } \\
\text { pagamento ao desempenho; } \\
\text { ii) a relação entre incentivos aos gestores e } \\
\text { competição é convexa, indicando que o efeito } \\
\text { marginal da competição sobre os incentivos aos } \\
\text { gestores aumenta até a competição atingir certo } \\
\text { nível; } \\
\text { iii) relação negativa entre valor da firmae } \\
\text { competição no mercado de produtos. }\end{array}$ \\
\hline
\end{tabular}


Os estudos apresentam diversas possibilidades de pesquisas relacionando competição no mercado de produtos e algum tema específico (ou adjacente) de governança. Ademais, variadas métricas são empregadas com o intuito de representar a competição e também governança corporativa.

Em relação aos resultados dos estudos, não há uma conclusão única a ser extraída. Todavia, a variável competição no mercado de produtos mostrou-se relevante na grande maioria. As pesquisas investigam diferentes problemas, em diferentes países, valendo-se de diferentes amostras, bases de dados e períodos. Portanto, a idéia de que a variável competição pode ser relevante nos estudos sobre governança corporativa parece razoavelmente comprovada. 


\section{PROCEDIMENTO METODOLÓGICO}

\subsection{Método de pesquisa}

Segundo Marconi e Lakatos (2005, p. 83), o método da pesquisa é o conjunto das atividades sistemáticas e racionais que, com maior segurança e economia, permite alcançar o objetivo, definindo o caminho a ser seguido, detectando erros e auxiliando as decisões do pesquisador. Assim, em função do objetivo da presente dissertação ser estudar a relação entre competição no mercado de produtos e a qualidade de governança corporativa das companhias abertas brasileiras, bem o potencial efeito da interação entre essas variáveis sobre o desempenho da firma, trata-se de um estudo correlacional. Sampieri et al. (2006) afirmam que o objetivo deste tipo de estudo é avaliar a relação entre duas ou mais variáveis. Do ponto de vista epistemológico, trata-se de uma pesquisa empírico-analítica.

Para testar a relação entre competição no mercado de produtos, qualidade de governança corporativa das companhias e desempenho operacional, foram aplicadas ferramentas estatísticas para responder às duas questões de pesquisa. Especificamente, são aplicadas as técnicas de regressão linear simples, regressão linear múltipla do tipo seção cruzada e regressões com dados dispostos em painel, tanto efeito fixo quanto efeito aleatório.

\subsection{Definições teórica e operacional das variáveis-chave}

A definição teórica e operacional das variáveis "governança corporativa", "competição no mercado de produtos" e "desempenho" é central para a correta identificação do relacionamento entre as variáveis da pesquisa. Portanto, nas subseções abaixo são feitas algumas considerações sobre tais variáveis. 


\subsubsection{Governança corporativa}

A representação da governança corporativa pode ser feita por meio de diferentes aproximações (LEAL; CARVALHAL-DA-SILVA, 2005). Podem ser utilizadas mensurações individuais de uma determinada característica ou índices amplos que considerem várias dimensões de governança. Exemplos do primeiro tipo são encontrados nos trabalhos de Guadalupe e Pérez-González (2006) e Saito e Silveira (2008). Ambos os trabalhos utilizam a diferença de valor de mercado entre as ações com e sem direitos a voto como aproximação para a governança corporativa. Outros estudos, tanto no exterior quanto no Brasil, utilizam amplos índices para mensurar a qualidade de governança corporativa (GOMPERS et al., 2003; BEBCHUK et al., 2004; BROWN; CAYLOR, 2006; KLAPPER; LOVE, 2002; LEAL; CARVALHAL-DA-SILVA, 2005; SILVEIRA, 2004; BLACK et al., 2006; BLACK, 2001).

Não obstante a extensa utilização de índices amplos de governança corporativa em estudos da área, não há consenso sobre a real utilidade destas métricas para aproximar a estrutura de governança corporativa das companhias. Uma crítica relevante pode ser vista no trabalho de Bhagat et al. (2007). Segundo os autores, a utilização de índices de governança em estudos tem duas limitações importantes. Primeiramente, nenhum índice pode prever com máxima precisão o desempenho de uma companhia e simples aproximações, como a propriedade de ações por conselheiros externos, podem ser mais úteis do que amplos índices de governança desenvolvidos por acadêmicos. Em segundo lugar, os índices consideram implicitamente que os mecanismos de governança corporativa são complementares, no entanto há evidências de que são substitutos, um exemplo dessa constatação é feita por Gillan et al. (2006). Em resumo, para Bhagat et al. (2007) os índices de governança corporativa não conseguem capturar efetivamente boas e más práticas de governança, sugerindo que a idéia de one size fits all pode prejudicar os estudos da área, a exemplo das críticas também feitas por Coles et al. (2005) e Karuna (2008).

Sem desconsiderar as críticas, é utilizado na pesquisa um índice amplo denominado Índice de Governança Corporativa (IGOV) utilizado pelo IBGC como aproximação para a qualidade de governança corporativa das companhias. Por meio deste índice, o referido Instituto premia anualmente as companhias abertas com as melhores práticas de governança corporativa. Cabe ressaltar que as pesquisas de Kadyrzhanova e Rhodes-Kropf (2007), Karuna (2008), Giroud e 
Mueller (2008, 2009), Cremers et al. (2008), Chou et al. (2008) e Ammann et al.(2010) também analisam as relações entre competição, governança e desempenho por meio de índices ${ }^{16}$.

O índice da pesquisa é construído com base em um questionário composto por 20 questões e está disponível para os anos de 2005 a 2008. Das 20 questões, 16 são binárias, sendo que uma resposta positiva em relação ao que é tido como uma boa prática de governança corporativa representa um ponto adicional para a firma. Quatro questões apresentam pontuação intermediária (questões 1, 2, 16 e 17): 0; 0,5 e 1. Dessa forma, a pontuação mínima é 0 e a máxima 20. Nas regressões a pontuação das empresas será dividida por 2, a fim de que o índice varie entre 0 e 10. O IGOV é agrupado em quatro dimensões consideradas importantes na literatura de governança, a saber: i) disclosure; ii) composição e funcionamento do conselho; iii) ética e conflitos de interesse; e iv) direito dos acionistas. A primeira dimensão é composta por 6 questões, a segunda por 5, a terceira por 4 e a última por 5. O Quadro 3 apresenta as questões e os critérios específicos para pontuação no caso das quatro questões que apresentam pontuação intermediária.

\footnotetext{
${ }^{16}$ Contudo, os índices dos autores supracitados não são comparáveis ao da presente pesquisa, pois visam a mensurar, principalmente, o grau de proteção ao acionista contra aquisições hostis nestas pesquisas foram empregados o "G-index", desenvolvido por Gompers et al. (2003) e o "E-index", desenvolvido por Bebchuck et al. (2004). A exceção é o trabalho de Ammann et al. (2010). Nele, os autores utilizam um índice composto por seis dimensões, desenvolvido pela consultoria GMI, possuindo maior proximidade com a pesquisa ora desenvolvida.
} 
Quadro 3 - Questionário do IBGC para companhias abertas

\begin{tabular}{|c|c|}
\hline Dimensões e peguntas & Critério es pecífico para avaliação \\
\hline \multicolumn{2}{|c|}{ Dimensão 1: Disclosure } \\
\hline $\begin{array}{l}\text { 1. Algum documento público da companhia inclui informações } \\
\text { sobre políticas e mecanismos estabelecidos para lidar com } \\
\text { situações de conflitos de interesses e/ou transações compartes } \\
\text { relacionadas? }\end{array}$ & $\begin{array}{l}0 \text { (a empresa não divulga informações); } 0,5 \text { (divulga alguma } \\
\text { informação) e } 1 \text { (divulga informações que consideradas } \\
\text { "substanciais"). }\end{array}$ \\
\hline $\begin{array}{l}\text { 2. A companhia revela informações sobre a remuneração da } \\
\text { administração, desagreg ando o percentual pago ao conselho e à } \\
\text { diretoria e informando as proporções pagas sob a forma de } \\
\text { remuneração fixa e variável? }\end{array}$ & $\begin{array}{l}0 \text { (a empresa não desagrega CA e diretoria); 0,5 (desagrega mas } \\
\text { não informa remuneração fixa e variável ou não desagrega mas } \\
\text { informa proporção paga sob a forma de remuneração fixa e } \\
\text { variável); } 1,0 \text { (empresa desagrega e informa remuneração fixa e } \\
\text { variável). }\end{array}$ \\
\hline $\begin{array}{l}\text { 3. A empresa teve parecer de auditoria independente sem } \\
\text { ressalvas nos últimos } 5 \text { anos? }\end{array}$ & $\begin{array}{l}0 \text { se a empresa apresentou parecer com ressalva; } 1 \text { se nos últimos } 5 \\
\text { anos a empresa não teve ressalvas em suas demonstrações. }\end{array}$ \\
\hline $\begin{array}{l}\text { 4. O website da companhia possui uma seção de Relações com } \\
\text { os Investidores, sendo possível obter o Relatório Anual por meio } \\
\text { dele? }\end{array}$ & $\begin{array}{l}0 \text { se companhia não possui um website com uma seção de } \\
\text { Relações com Investidores que possibilite ao investidor acessar o } \\
\text { Relatório Anual; } 1 \text { se a empresa possui uma seção de Relações com } \\
\text { Investidores que possibilite ao investidor acessar o Relatório } \\
\text { Anual. }\end{array}$ \\
\hline $\begin{array}{l}\text { 5. O website disponibiliza as apresentações realizadas para } \\
\text { analistas de mercado? }\end{array}$ & $\begin{array}{l}0 \text { se o website da companhia não disponibilizar as apresentações } \\
\text { feitas para analistas de mercado; } 1 \text { se as apresentações feitas para } \\
\text { analistas são disponibilizadas no website da companhia. }\end{array}$ \\
\hline $\begin{array}{l}\text { 6. O Relatório Anual inclui uma seção específica dedicada à } \\
\text { implementação de princípios de Governança Corporativa? }\end{array}$ & $\begin{array}{l}0 \text { se o website não disponibiliza uma seção específica dedicada à } \\
\text { implementação de princípios de governança corporativa; } 1 \text { se o } \\
\text { website disponibiliza uma seção específica. }\end{array}$ \\
\hline \multicolumn{2}{|c|}{ Dimensão 2: Composição e Funcionamento do Conselho } \\
\hline $\begin{array}{l}\text { 7. Presidente do Conselho e Presidente Executivo são pessoas } \\
\text { diferentes? }\end{array}$ & $\begin{array}{l}0 \text { se uma mesma pessoa ocupa ambos os cargos; } 1 \text { se os cargos } \\
\text { são ocupados por pessoas diferentes. }\end{array}$ \\
\hline $\begin{array}{l}\text { 8. A empresa possui qualquer tipo de comitê do conselho } \\
\text { evidenciado em informações públicas (Estatuto Social, Relatório } \\
\text { Anual, website, etc.)? }\end{array}$ & $\begin{array}{l}0 \text { se não há evidências da existência de comitês do conselho em } \\
\text { informações pública; } 1 \text { se há evidências da existência de comitês } \\
\text { do conselho eminformações públicas. }\end{array}$ \\
\hline
\end{tabular}


Quadro 3 - Questionário do IBGC para companhias abertas (continuação)

\begin{tabular}{ll}
\hline \multicolumn{1}{c}{ Dimensões e peguntas } & \multicolumn{1}{c}{ Critério específico para avaliação } \\
\hline $\begin{array}{l}\text { 9. O conselho é composto apenas por conselheiros externos, com } \\
\text { exceção do presidente da diretoria? }\end{array}$ & $\begin{array}{l}\text { 0 se um dos conselheiros, com exceção do presidente da diretoria, } \\
\text { conselho forem externos ou independentes, com exceção do } \\
\text { presidente da diretoria. }\end{array}$ \\
\hline $\begin{array}{l}\text { 10. O conselho tem entre 5 e 9 membros, conforme recomendado } \\
\text { pelo Código das Melhores Práticas do IBGC? }\end{array}$ & $\begin{array}{l}\text { 0 se o número de membros do conselho for diferente do intervalo } \\
\text { recomendado pelo IBGC; 1 se o número de membros do conselho } \\
\text { estiver de acordo com o intervalo sugerido pelo IBGC. }\end{array}$ \\
\hline
\end{tabular}

11. Os membros do conselho têm mandatos de 1 ano, conforme recomendado pelo Código das Melhores Práticas do IBGC?

0 se o mandato do conselho é diferente de um ano; 1 se o mandato do conselho é de 1 ano.

\section{Dimensão 3: Ética e conflitos de interesse}

12. A porcentagem de ações não votantes é menor do que $20 \%$ do total do capital?
0 se o percentual de ações não votantes for maior ou igual a $20 \%$ do capital total; 1 se o percentual de ações for menor do que $20 \%$ do capital total.

0 se o percentual de ações com direito a voto do grupo controlador for maior que o percentual de ações detido pelo gupo controlador em relação ao total de ações da empresa; 1 se o percentual de ações com direito a voto do grupo controlador for igual ou menor que o percentual de ações detido pelo grupo controlador em relação ao total de ações da empresa.

0 se empréstimos em favor do controlador ou outas partes relacionadas não forem proibidos pelo estatuto; 1 se o no estatuto houver proibição de empréstimos ao controlador e outras partes relacionadas. 0 se o estatuto não incentiva a participação em as sembléias; 1 se o estatuto incentiva a participação em as sembléias, por meio da dispensa do envio prévio da documentação e adotando o princípio da boa fé. assembléias, não exigindo o envio prévio da documentação e adotando o princípio da boa fé?

Dimensão 4: Direito dos acionistas
0 (emissão de preferenciais, sem direito de voto em quaisquer matérias); 0,5 - item b (direito de voto às preferenciais em matérias relevantes); 1,0 - item a (conceito uma ação - um voto).

a) a empres a concede a cada ação um voto?

b) a empresa tem ações preferenciais emitidas e concede direito de voto a todas as ações nas decisões de maior impacto (Nível 2, p.ex.)

0 (tag along como mera obrigação legal); 0,5 (empresa concede tag along apenas para as $\mathrm{ON}$ ou apenas para as PN além das 17. A companhia garante direitos de tag-along além dos que são exigências legais); 1,0 (empresa concede tag along para as ON e legalmente exigidos? para as $\mathrm{PN}$ além das exigências legais). Caso a empresa possu apenas ON emitidas e conceda tag along além das exigências legais para estas ações, deve receber 1,0 ponto.

18. O controle da companhia é direto? 0 se o controle da companhia for exercido por meio de estruturas piramidais; 1 se o controle da companhia for exercido diretamente.

0 se o acordo entre sócios vincular ou restringir o exercício do 19. Os acordos entre sócios se abstêm de vincular ou restringir o direito de voto de quaisquer membros do conselho de exercício do direito de voto de quaisquer membros do Conselho de Adminis tração, ou de indicar quaisquer diretores para a sociedade?

administração e permitir a indicação de quaisquer diretores para a sociedade; 1 se o acordo de acionis tas se abster de vinvular ou restringir o direito de voto de quaisquer membros do conselho de administração, ou de indicar quaisquer direitores para a sociedade.

20. O free-float é igual ou maior do que os $25 \%$ exigidos para 0 se o free-float for menor do que $25 \%$; 1 se o free-float for maior listagem nos segmentos especiais de governança da Bovespa? ou gual a $25 \%$.

Fonte: Adaptado de IBGC - Questionário para companhias

abertas aprovado pelo Comitê Gestor do Prêmio IBGC 
Adicionalmente, como forma de testar a robustez dos resultados, também utilizou-se o índice de governança elaborado por Leal e Carvalhal-da-Silva (2005), todavia para um período diferente. O índice é composto por 24 questões binárias, divididas em quatro categorias, a saber: disclosure; composição e funcionamento do conselho; ética e conflitos de interesse; e direito dos acionistas. O Anexo 1 apresenta a relação de questões. O índice está disponível entre os anos de 1998 e 2004, com intervalo de dois anos ${ }^{17}$.

\subsubsection{Medidas de competição}

\subsubsection{Discussão teórica}

A escolha de uma métrica para aproximar o conceito de competição não é trivial. Davies et al (1989, p. 79) afirmam que a discussão sobre qual a melhor métrica de competição atrai consideráveis debates. Não obstante, conforme discute Cubbin (1988), para a realização de testes empíricos, é necessário transformar os conceitos teóricos em métricas operacionalizáveis, que considerarão em sua construção determinadas características do mundo real, como o fato de os produtos não serem homogêneos e as firmas produzirem diversos produtos. O fato é que não há consenso sobre qual a melhor métrica para a aproximação do construto "competição no mercado de produtos".

Para Schmalensee (1989, p. 966), por exemplo, uma métrica apropriada de competição deveria ser derivada das teorias de oligopólio. Ainda segundo o autor, muitos pesquisadores utilizam índices de concentração como aproximação de competição em função da facilidade de obtenção de dados e por muitos estudos terem encontrado medidas alternativas altamente correlacionadas. Neste sentido, Kwoka Jr (1981) avalia os problemas que a inadequada especificação de uma métrica de competição acarreta nos estudos. Segundo o autor, a escolha dos índices de concentração, que serve como aproximação para o conceito de competição, é relevante, pois as consequiências práticas de escolhas inapropriadas é o efeito sobre a significância das relações estatísticas encontradas em alguns estudos.

${ }^{17} \mathrm{O}$ autor agradece ao IBGC e aos pesquisadores Ricardo Leal e André Carvalhal-da-Silva pela gentil disponibilização dos dados para a consecução desta pesquisa. 
Boone et al. (2005) afirmam que, não obstante a onipresença do conceito de competição nos estudos econômicos, geralmente são aplicadas métricas simples para aferir o grau de competição nos mercados. As métricas comumente utilizadas nos estudos são: i) índice de concentração; ii) participação no mercado; iii) HHI; e iv) PCM. Boone et al. (2007) também criticam a adoção de métricas simples para o cálculo de competição, comumente adotadas nos trabalhos empíricos de OI. Na pesquisa é proposta a utilização de uma métrica denominada elasticidade do lucro (PE), em que PE é mensurada para um mercado e é definida como o percentual de queda no lucro em função de um aumento percentual no custo marginal. Boone et al. (2007) afirmam que em todos os mercados um aumento nos custos reduz o lucro. No entanto, argumentam os autores, em um mercado mais competitivo o mesmo aumento no custo marginal levaria a um decréscimo no lucro bem maior. A intuição básica é que em mercados mais competitivos as companhias são punidas severamente por sua ineficiência. Assim, PE é uma medida mais apropriada do que o HHI e PCM, segundo os autores. Entre outras conclusões relevantes do estudo, os autores identificam que HHI é uma medida pobre de competição quando comparada ao PCM ou PE. Outra conclusão importante do estudo é o fato de os autores terem encontrado um aumento no nível de concentração em função de empresas ineficientes não resistirem e saírem do mercado, cujo resultado seria o aumento da concentração, pois sobraria mercado para as companhias mais eficientes.

Os trabalhos acima sugerem que os índices de concentração são amplamente utilizados na literatura de OI para aproximar o construto "competição no mercado de produtos", não obstante as críticas. Assim, abaixo são realizadas algumas considerações sobre esse tipo de métrica.

De acordo com Ferguson e Ferguson (1994, p. 56), a lógica do uso de índices que captam a concentração de mercado se deve à crença de que em mercados concentrados as companhias poderiam exercer poder de mercado, cujo resultado seria a extração de ganhos anormais. Contudo, argumentam os autores, o uso isolado de índices de concentração para estimar a probabilidade de exercício de poder mercado está sujeito a erros, dado que não contemplam a interação entre companhias. Curry e George (1983) destacam que a complexidade dos negócios é tamanha que na prática é improvável utilizar uma métrica superior a outras em quaisquer situações. Caso possível, os autores recomendam a utilização de mais de uma 
métrica de concentração, no entanto citam a disponibilidade de dados como uma restrição a esta opção. Entretanto, embora seja claro que nenhum índice ideal de concentração exista, é possível fazer algum progresso por meio da coleção de propriedades desejáveis (CURRY; GEORGE, p. 204, 1983).

Carlton e Perloff (2000) também criticam a utilização dos índices de concentração. Para os autores, as métricas de concentração possuem dois graves problemas. O primeiro deles é que muitos fatores determinam a concentração de mercado, sendo que a maioria das métricas usadas é endógena. $\mathrm{O}$ segundo problema das métricas de concentração é a imprecisão na definição dos mercados e indústria. Geralmente, as agregações não correspondem ao mercado relevante para o produto.

Após a exposição desses aspectos, é razoável verificar quais são as métricas comumente utilizadas nos estudos que relacionam competição no mercado de produtos e governança corporativa. De forma geral, as seguintes variáveis são utilizadas como proxy de competição: i) penetração das importações; ii) o lucro econômico (denominado nos estudos de economic rents); iii) participação de mercado; iv) Product Market Regulation (PMR), que é um índice desenvolvido pela OCDE; v) desregulamentação de setores, que propicia a possibilidade de realizar um experimento, segundo os autores que utilizam essa metodologia; vi) aproximações para o Índice de Lerner; vii) número de competidores; viii) grau de substitutibilidade dos produtos; ix) barreiras de entrada, mensurada pelo investimento no ativo permanente; $\mathrm{x}$ ) soma da participação de mercado das principais empresas, como, por exemplo, os índices C4, e C6; e xi) Índice de Herfindahl-Hirschmann (HHI).

Apesar da diversidade de proxies, constata-se que a maioria dos estudos revistos na pesquisa aproxima o conceito de competição por meio do HHI. Exemplos são os estudos de DeFond e Park (1999), Januszewski et al. (2001), Randoy e Jenssen (2004), Rennie (2006), Gillan et al. (2006), Grullon e Michaely (2006), Kadyrzhanova e Rhodes-Kropf (2007), Cremers et al. (2008), Giroud e Mueller (2008; 2009), Chou et al. (2008), Pattanayak (2008), Chhaochharia et al. (2009), Beiner et al. (2009) e Li (2010).

$\mathrm{Na}$ pesquisa, avaliou-se a viabilidade da implementação das métricas de competição, considerando a disponibilidade de dados. Optou-se pelo HHI como principal variável para 
estimar a competição no mercado de produtos. Além disso, a fim de testar a robustez dos resultados, serão utilizadas a razão de concentração das quatro principais companhias do mercado (JANUSZEWSKI et al., 2001; CUÑAT; GUADALUPE, 2004; PATTANAYAK, 2008) e o número de competidores (KADYRZHANOVA; RHODES-KROPF, 2007; Li, 2010). Conforme explicado mais adiante, cada uma das medidas será utilizada de acordo com a disponibilidade de dados das bases utilizadas na pesquisa.

O HHI, apesar de ser objeto de diversas críticas, é amplamente utilizado como um dos meios para identificar o grau de competição em um setor. De acordo com Rhoades (1993), este índice tem um alto grau de visibilidade em razão de ser utilizado pelo Departamento de Justiça dos Estados Unidos em casos de fusão. No Brasil, o CADE também o utiliza como ferramenta auxiliar para avaliar a concentração de setores ${ }^{18}$. A idéia é que um aumento no HHI aumente a probabilidade de exercício do poder de mercado por parte das empresas. Davies et al. (1989, p. 85) afirmam que o HHI talvez seja a melhor opção entre os índices de concentração, em função de simultaneamente refletir o número de competidores de um mercado e a desigualdade de participação de cada um.

Rezende (1994) e Schimidt e Lima (2002, p. 4) ensinam que o HHI é dado pela seguinte equação:

$$
\mathrm{HHI}=\sum_{i=1}^{n} \beta_{i}^{2}
$$

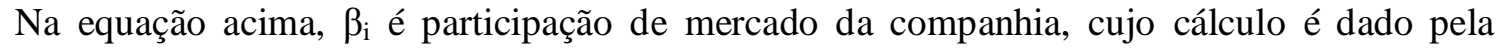
seguinte equação:

$$
\beta_{i}=\frac{Q_{i}}{\sum_{i=1}^{m} Q_{i}}
$$

${ }^{18}$ O Guia para análise econômica de atos de concentração horizontal, 2001, do CADE apresenta os conceitos utilizados por este órgão para avaliar potenciais efeitos sobre a concorrência em casos de atos de concentração. Um exemplo prático da utilização do HHI pode ser obtido no Parecer técnico no 188 sobre o ato de concentração nº 08012.005846/99-12, de 1999. Trata-se da análise da fusão entre Brahma e Antárctica. 
$\mathrm{Na}$ equação acima, $\mathrm{Q}_{\mathrm{i}}$ representa uma métrica utilizada para aferir a participação de mercado da companhia. Para a definição da participação de mercado geralmente utiliza-se o faturamento da companhia (HOU; ROBINSON, 2006, p,10). No entanto, outras variáveis podem ser utilizadas, por exemplo: produção física, valor adicionado, ativo total entre outras.

Segundo Schimidt e Lima (2002, p. 4), o HHI pode ser expressão de duas formas. No primeiro caso, o valor é considerado em \%. Isso significa que se em um mercado existir apenas uma empresa, sua participação será de $100 \%$. Logo, o valor do HHI seria de $10.000^{19}$. Prosseguindo com base nos autores, se em um mercado todas as firmas tivessem participações iguais, o cálculo do HHI seria dado pela divisão de 10.000 pelo número de firmas, $\mathrm{N}^{20}$. Portanto, quanto maior o número de firmas, representado por $\mathrm{N}$, menor seria o HHI. A segunda forma de expressar o índice consiste em desconsiderar o \%. Portanto, se uma empresa fosse a única de um mercado, o índice seria igual a $1^{21}$. Com raciocínio análogo ao feito acima, se em um mercado todas as firmas tivessem participações iguais, o cálculo do HHI seria dado pela divisão de 1 pelo número de firmas, $\mathrm{N}^{22}$.

Do exposto, tem-se que, no limite, o índice pode variar de $[0,10.000]$ ou de $[0,1]$, sendo que quanto mais próximo de 10.000 ou 1, maior será a concentração do setor e, por conseguinte, quanto mais próximo de 0 , menor será a concentração do setor. Assim, tendo em vista os objetivos da pesquisa, quanto maior o HHI menor será o grau de competição no mercado de produtos e quanto menor o HHI maior a competição.

$$
\begin{aligned}
& { }^{19} \mathrm{HHI}=\sum_{i=1}^{n}(100)^{2}=10.000 . \\
& { }^{20} \mathrm{HHI}=\sum_{i=1}^{n}\left[\frac{100}{N}\right]=\frac{10.000}{N} . \\
& { }^{21} \mathrm{HHI}=\sum_{i=1}^{n}(1)^{2}=1 . \\
& { }^{22} \mathrm{HHI}=\sum_{i=1}^{n}\left[\frac{1}{N}\right]=\frac{1}{N} .
\end{aligned}
$$


Quanto às razões de concentração, Schimidt e Lima (2002, p. 3) as definem como a soma da participação de mercado das $\mathrm{N}$ firmas de um mercado. Formalmente, define-se razão de concentração por meio da seguinte equação:

$$
C_{n}=\sum_{i=1}^{n} \beta i
$$

$\mathrm{Na}$ Equação acima, $\beta_{\mathrm{i}}$ é participação de mercado da companhia, cujo cálculo é dado pela seguinte equação:

$$
\beta_{i}=\frac{Q_{i}}{\sum_{i=1}^{m} Q_{i}}
$$

$\mathrm{Na}$ pesquisa, foram utilizadas as quatro principais empresas de um mercado para a formação da razão de concentração. Essa métrica é conhecida na literatura como C4. Quanto maior esse número, mais concentrado o mercado. E, potencialmente, menor a competição.

Em relação ao número de competidores, foi obtido pela soma do número de empresas que atuam em um determinado mercado, aproximado pela CNAE a três e quatro dígitos. Quanto maior o número de empresas, potencialmente maior é a competição no setor, segundo os objetivos da pesquisa.

\subsubsection{Operacionalização}

Hou e Robinson (2006) e Schmidt e Lima (2002) destacam que o cálculo do HHI necessita da utilização da distribuição integral das participações de mercado de todas as companhias da indústria, por isso os autores afirmam que a sua implementação prática pode tornar-se difícil, principalmente em setores nos quais as empresas têm participações relativamente próximas, visto que a utilização de algumas empresas do setor no cálculo tenderia a apresentar resultados distorcidos em relação ao real nível de concentração do setor. 
No mercado brasileiro, as informações sobre a receita ou quaisquer outras variáveis que possam ser utilizadas para calcular a participação de mercado de todas as empresas não estão prontamente disponíveis. Há bases de dados com informações para companhias de capital aberto, contudo estas companhias representam um universo restrito em relação ao total de empresas brasileiras. Como evidência, a PIA, Pesquisa Industrial Anual, do IBGE, Instituto Brasileiro de Geografia e Estatística, de 2007, que contempla as empresas das indústrias de extração e transformação, mostra que existem 3.688 empresas de médio e grande porte no Brasil, apenas nestas indústrias. Portanto, calcular o HHI considerando apenas esse universo poderia produzir resultados tendenciosos.

A solução adotada na pesquisa para minimizar um possível viés advindo da utilização de poucas empresas foi calcular o HHI por meio da PIA-Empresa ${ }^{23}$ do IBGE $^{24}$, bem como o C4 e o número de competidores. De acordo com o IBGE (2007), o objetivo da PIA-Empresa é “[...] identificar as características estruturais básicas do segmento empresarial da atividade industrial do País e suas transformações no tempo, através de levantamentos anuais, tomando como base uma amostra de empresas industriais". A primeira informação importante é que a PIA-Empresa é útil para entender as "características estruturais básicas" da indústria. Isto vai ao encontro do objetivo de compreender se um mercado é mais ou menos concentrado. $\mathrm{O}$ segundo aspecto é que trata-se de uma amostra. Portanto, nem mesmo recorrendo-se à PIAEmpresa é possível obter o HHI de todas as empresas de um setor. A Tabela 1 apresenta que a amostra da PIA é bastante ampla:

\begin{tabular}{cc}
\multicolumn{2}{c}{ Tabela 1 - Amostra da PIA } \\
\hline Ano & Amostra \\
\hline 2002 & 130,913 \\
2003 & 135,129 \\
2004 & 138,612 \\
2005 & 143,979 \\
2006 & 147,413 \\
2007 & 154,988 \\
\hline
\end{tabular}

Fonte: elaborada pelo autor com base na Pesquisa Industrial Anual dos anos de 2002 a 2007.

\footnotetext{
${ }^{23}$ Há também a PIA-Poduto.

${ }^{24}$ O IBGE possui pesquisas para o setor de serviços e comércio, Pesquisa Anual dos Serviços (PAS) e Pesquisa Anual do Comércio (PAC), respectivamente. Tentou-se obter dados dessas pesquisas para complementar os dados da PIA e aumentar a amostra da pesquisa, contudo não foi obtido êxito.
} 
Não obstante os benefícios, a utilização dos dados da PIA-Empresa também gera alguns problemas. O primeiro se refere à perda de setores. O âmbito da pesquisa do IBGE é composto apenas pelo setor industrial. Especificamente, na PIA-Empresa são contempladas apenas empresas pertencentes às indústrias extrativas ou de transformação. Sendo assim, como o índice do IBGC é calculado para as empresas abertas em geral, nem todas podem ser aproveitadas, visto que as empresas de capital aberto não se restringem ao âmbito específico da PIA-Empresa. Além disso, como a última PIA-Empresa disponível se refere aos dados de 2007, um ano de dados do índice do IBGC também não poderá ser utilizado. O segundo problema é que os dados são agregados por Classificação Nacional de Atividades Econômica $(\mathrm{CNAE})^{25}$, versão 1.0. Dessa forma, não é possível calcular o HHI e C4 de forma direta apenas consultando-se os dados da pesquisa, já que seria necessário conhecer a receita, ou outra variável de participação de mercado, de cada empresa para efetuar o cálculo ${ }^{26}$. Este segundo problema foi contornado mediante solicitação do cálculo do HHI e C4 diretamente para o IBGE, bem como o número de competidores considerados nos cálculos. Portanto, os dados sobre o $\mathrm{HHI}, \mathrm{C} 4$ e número de competidores utilizados na pesquisa foram disponibilizados pelo IBGE, utilizando como variável de participação de mercado a receita bruta das empresas no caso dos índices. O IBGE disponibiliza o HHI calculado no intervalo [0,1]. Não obstante os problemas apontados, a perda de observações é compensada pelo aumento do rigor na definição de um índice de concentração mais próximo da realidade.

Na PIA-Empresa, conforme acima citado, os dados são agregados por meio da CNAE 1.0 . O Quadro 4 coopera na compreensão de sua divisão ${ }^{27}$ :

\footnotetext{
${ }^{25}$ Segundo o documento Introdução à Classificação Nacional de Atividades Econômicas, "A CNAE tem como principal propósito ser uma classificação estandardizada das atividades econômicas produtivas, provendo um conjunto de categorias para serem usadas na coleta e divulgação de estatísticas por tipo de atividade econômica. Essas categorias são definidas, o máximo possível, de acordo com a forma como o processo econômico está organizado nas unidades e como se quer que seja descrito nas estatísticas econômicas."

${ }^{26}$ No trabalho de Mendonça et al. (2008) os autores desenvolvem uma metodologia para calcular o HHI por meio dos dados agregados da PIA-Empresa.

${ }^{27}$ Há uma quinta divisão denominada CNAE-Fiscal. Esta subsclasse é utilizada pelos órgãos da administração pública nas três esferas do governo e visa padronizar os códigos de identificação das unidades produtivas do país, conforme informação coletada na página eletrônica (www.ibge.gov.br/concla) da Comissão Nacional de Classificação. Todavia, a partir da implantação da CNAE 2.0, deixou-se de tratar as subclasses como CNAEFiscal e passou-se a tratá-las como um detalhamento para uso da Administração Pública.
} 


\begin{tabular}{llc}
\multicolumn{3}{c}{ Quadro 4 - Divisão da CNAE } \\
\hline Nível & Código & Número de categorias \\
\hline Seção & Alfabético de 1 dígito & 2 \\
Divisão & Numérico de 2 dígitos & 27 \\
Grupo & Numérico de 3 dígitos & 111 \\
Classe & Numérico de 4 dígitos & 300 \\
\hline
\end{tabular}

FONTE: Pesquis a Industrial Anual do IBGE. 2007.

Davies et al. (1989, p. 86) argumentam que quando se utiliza índices de concentração para analisar a estrutura de mercado, duas questões emergem: i) como definir o mercado para cálculo dos índices?; e ii) como mensurar a participação de cada firma? O segundo questionamento é, de certa forma, respondido, visto que a receita bruta das empresas foi utilizada como uma aproximação para a participação de mercado da companhia. Com relação ao primeiro questionamento, faz-se necessária uma maior discussão.

A pesquisa pretende identificar setores que são mais ou menos competitivos e, assim, relacionar essa característica do setor com a estrutura de governança das companhias, bem como a interação entre tal característica e a estrutura de governança sobre o desempenho das companhias. Logo, o questionamento feito por Davies et al. (1989) tem um impacto significativo sobre a pesquisa, visto que a definição setorial é fundamental para que o relacionamento objeto do estudo seja corretamente identificado. Idealmente, a pesquisa deveria investigar as relações acima citadas valendo-se do conceito de mercado relevante.

Para Ferguson (1992), a distinção entre mercado e indústria é importante para análises econômicas. Mercado refere-se a grupos que produzem produtos que são substitutos do ponto de vista dos compradores. A elasticidade-cruzada da demanda tende a ser alta entre produtos do mesmo mercado e baixa entre produtos de outros mercados. Em contraste, o termo "indústria" é empregado para grupos que produzem produtos substitutos do ponto de vista dos fornecedores. A diferença entre mercados e indústria cria problemas de ordem empírica para as pesquisas, porque as principais bases de dados governamentais referem-se à indústria e não ao mercado, continua Ferguson (1992). Em geral, quando maior for a desagregação dos dados, mais próximo da definição de "mercado" estarão os dados da indústria. Shepherd (1990) também discute a importância da definição de mercado e indústria e cita a elasticidade-cruzada como uma forma razoável de definir o mercado de cada produto. No 
entanto, o autor reconhece a dificuldade prática deste tipo de procedimento, pois seria tecnicamente impossível calcular a elasticidade cruzada de uma forma tão rápida. Hollanda Filho (1982) também discute estes problemas. O autor discute o fato de que as informações disponibilizadas pelos órgãos governamentais são agrupadas por indústrias, sendo que a produção de maior relevância na atividade da companhia é a utilizada para classificá-la em uma ou outra indústria. Assim, diversas informações relevantes para cálculo efetivo da competição são perdidas.

O item 25 do Guia para Análise Econômica de Atos de Concentração Horizontal ${ }^{28}$, expedido pela Portaria Conjunta SEAE/SDE ${ }^{29} \mathrm{n}^{\text {o }} 50$, de 2001, estabelece que a análise dos atos de concentração passa por cinco etapas principais, sendo que a primeira dessas etapas é a definição do mercado relevante ${ }^{30}$. Dessa forma, identificar o mercado relevante é fundamental para investigar situações que envolvam concorrência. Hollanda Filho (1982), Shepherd (1990), Ferguson (1992) e Carlton e Perloff (2000) citam a definição de mercado como um aspecto crítico em estudos sobre competição.

A definição de mercado relevante, segundo o item 28 da Portaria Conjunta SEAE/SDE, é “[...] o menor grupo de produtos e a menor área geográfica necessários para que um suposto monopolista esteja em condições de impor um 'pequeno porém significativo e não transitório' aumento de preços." Sendo assim, para a pesquisa efetivamente captar o real grau de concorrência entre as empresas de um mercado, seria necessário identificar o mercado relevante de cada uma delas. Contudo, dado que o escopo da pesquisa abrange diversas companhias, o procedimento de identificação do mercado relevante não é viável.

Assim, como aproximação para o mercado das companhias será utilizada a CNAE principal ${ }^{31}$ de cada uma, pois a PIA-Empresa já agrupa os estabelecimentos empresariais dessa forma.

\footnotetext{
${ }^{28}$ O objetivo do Guia é “[...] apresentar os procedimentos e os princípios que a SEAE e a SDE adotam na análise desses atos" (SEAE/SDE, Portaria Conjunta n $\left.{ }^{\circ} 50\right)$. Os atos a que o trecho se referem são as "[...] integrações horizontais de empresas, isto é, concentrações que envolvam provedores de bens ou serviços que sejam competidores entre si” (SEAE/SDE, Portaria Conjunta $n^{\circ} 50$ ).

${ }^{29}$ Secretaria de Acompanhamento Econômico (SEAE) e Secretaria de Direito Econômico (SDE).

${ }^{30}$ As demais etapas são as seguintes: i) determinação da parcela de mercado sob controle das empresas requerentes; ii) exame da probabilidade de exercício do poder de mercado;iii) exame das eficiências econômicas geradas pelo ato; e iv) avaliação da relação entre custos e benefícios derivados da concentração e emissão de parecer final.

${ }^{31} \mathrm{Na}$ prática, conforme o documento Introdução à Classificação Nacional de Atividades Econômicas - CNAE versão 2.0, os estabelecimentos empresariais desempenham mais de uma atividade, todavia precisam ser classificação em um código da CNAE. Nos casos de estabelecimentos com variadas atividades, a classificação é feita levando em consideração a principal atividade do estabelecimento. Ainda segundo o documento, no Brasil
} 
Ao nível do grupo (CNAE a três dígitos), o IBGE disponibilizou o cálculo do HHI, C4 e o número de competidores e ao nível da classe (CNAE a quatro dígitos) ${ }^{32}$ apenas o HHI e o número de competidores, sendo este último o nível mais desagregado utilizado no sistema estatístico. Na pesquisa, ambos os níveis serão utilizados como aproximação para o mercado de atuação da companhia, a fim checar a robustez dos resultados, sendo que o agrupamento por classe tende a se aproximar melhor do conceito de mercado, visto que especifica mais claramente a atividade principal da empresa. No Quadro 4 observa-se que a CNAE ao nível do grupo possui 111 categorias e ao nível de classe possui 300 categorias, o que respalda a afirmação anterior, pois o maior número de categorias ao nível de classe possibilita o melhor enquadramento das atividades das empresas.

Essa opção por definir o mercado das companhias por meio da atividade econômica principal é passível de críticas, pois do ponto de vista teórico um mercado agruparia empresas com características semelhantes e que de fato concorressem entre si. Contudo, esse não é um problema exclusivo desta pesquisa. Os trabalhos de Clarke (1989), Kahle e Walking (1996) e Bhoraj et al. (2003) discorrem justamente sobre o impacto das classificações setoriais utilizadas em pesquisas empíricas na área de finanças sobre os resultados dos testes estatísticos. Tomados em conjunto, os estudos concluem que as classificações setoriais utilizados nas pesquisas não conseguem de fato agregar companhias com características semelhantes. Além disso, as pesquisas que tratam da relação entre competição e governança também utilizam-se de classificações setoriais amplas como aproximação para o conceito de mercado. Como exemplos, tem-se o trabalho de Shin (2002) que utiliza a SIC, Standardized Industry Classification ${ }^{33}$ a quatro dígitos para definir um mercado, bem como os trabalhos de Karuna (2007; 2008), Chou et al. (2008) e Giroud e Mueller (2008;2009). Especificamente em Giroud e Mueller (2008), os autores, como teste de robustez, utilizam o NAICS, North-

\footnotetext{
a prática usual tem sido o uso da variável receita de vendas como ponderador para a determinação da atividade principal, visto que é uma aproximação simples para o conceito de valor adicionado, sendo este considerado a forma ideal de identificar a atividade principal de uma empresa.

${ }^{32}$ Ver Tabela 4.

${ }^{33}$ De acordo com Bhojraj et al. (2003, p. 7), foi a primeira classificação setorial dos Estados Unidos, desenvolvida no final dos anos 30. Pode-se dizer que guarda semelhanças com a CNAE brasileira.
} 
American Industry Classification System ${ }^{34}$ e o GICS, Global Industry Classification Standard ${ }^{35}$.

Para associar o HHI, C4 e número de competidores obtidos da PIA-Empresa às companhias do estudo, foi utilizada a CNAE de cada companhia. Todas possuem uma CNAE, porém para acessar a informação é necessário conhecer o Código Nacional da Pessoa Jurídica (CNPJ) de cada uma. A informação sobre o CNPJ está disponível no Informativo Anual (IAN). De posse do CNPJ, a página eletrônica da Receita Federal foi acessada e a CNAE obtida ${ }^{36}$. Os três primeiros dígitos da CNAE representam o grupo e os quatro primeiros dígitos representam a classe, portanto estes dígitos foram utilizados para associar o $\mathrm{HHI}, \mathrm{C} 4$ e número de competidores do mercado calculado pelo IBGE e agregados por CNAE à CNAE das companhias coletada na página eletrônica da Receita Federal.

Contudo, a CNAE coletada na página da Receita Federal é a CNAE $2.0^{37}$ e a PIA até 2007 utiliza a CNAE 1.0. Para sanar essa incompatibilidade de códigos, utilizou-se uma tabela de correspondência $^{38}$ entre a versão CNAE 2.0 e a versão CNAE 1.0.

O Quadro 5 ilustra como foi feita a coleta de dados:

\footnotetext{
${ }^{34}$ Bhoraj et al. (2003, p. 7) ensinam que esse é um sistema de classificação criado em conjunto pelo Canadá, Estados Unidos e México, em 1999. Ainda segundo Bhoraj et al. (2003, p. 8), o objetivo do NAICS é substituir o SIC.

${ }^{35}$ O GICS, segundo Bhoraj et al (2007, p. 9) é resultado do esforço conjunto de Morgan Stanley Capital International (MSCI) e Standard \& Poor's (S\&P). Esta classificação setorial também leva em conta a principal atividade de negócios da empresa.

${ }^{36} \mathrm{O}$ endereço da página eletrônica é www.receita.fazenda.gov.br.

${ }^{37}$ Para maiores detalhes, acesse o seguinte endereço eletrônico: http://www.ibge.gov.br/concla/default.php.

${ }^{38}$ A tabela de correspondência foi obtida no seguinte endereço eletrônico: http://www.ibge.gov.br/concla/default.php
} 
Quadro 5 - Exemplo de atribuição de HHI às empres as

Empresa: EMBRAER - Empresa Brasileira de Aeronáutica

CNPJ: $\quad 07.689 .002 / 0001-89$

CNAE 2.0 principal: $30.41-5-00$

Descrição da CNAE: Fabricação de aeronaves

Correspondência CNAE 1.0: $35.31-9$

Grupo: 353

Descrição do grupo: Construção, montagem e reparação de aeronaves

Classe: 3531

Descrição da classe: Construção e montagem de aeronaves

\begin{tabular}{ll} 
HHI do grupo 353: & HHI da classe 3531: \\
$\mathbf{2 0 0 5}-0,5394$ & $\mathbf{2 0 0 5}-0,8816$ \\
$\mathbf{2 0 0 6}-0,3767$ & $\mathbf{2 0 0 6}-0,5671$ \\
$\mathbf{2 0 0 7}-0,5727$ & $\mathbf{2 0 0 7}-0,8813$ \\
\hline
\end{tabular}

De acordo com o Quadro 5, o grupo CNAE coletado da base de dados da Receita Federal é o 304 e a classe é a 3041. Todavia, como a classificação da PIA é por meio da CNAE 1.0, é necessário utilizar a tabela de correspondência. A tabela indica que o grupo correspondente ao 304 é o 353 e classe correspondente é a 3531. Portanto, para o grupo, os seguintes índices foram calculados pelo IBGE e associados à Embraer: i) 2005 - 0,5394; ii) 2006 - 0,3767; e iii) 0,5727. Para a classe, foram associados à Embraer os seguintes valores: i) 2005 - 0,8816; ii) 2006 - 0,5671; e iii) 0,8813. Quanto ao C4 e o número de competidores, o mesmo procedimento foi seguido.

Todavia, a tabela de correspondência apresenta um problema: a CNAE 2.0 pode se referir a mais de uma CNAE 1.0. Para saná-lo, identificou-se todos os códigos da CNAE 2.0 que tinham mais de um correspondente na CNAE 1.0. Após isso, analisou-se empresa por empresa que possuíam esses códigos problemáticos para identificar a correspondência correta, que foi feita por meio da comparação das descrições de ambas as versões da CNAE. No Quadro 6 é apresentado um exemplo do procedimento adotado nesses casos. 
Quadro 6 - Corres pondência correta entre CNAE 2.0 e CNAE 1.0

Empresa: Marcopolo

CNPJ: $\quad 88.611 .835 / 0001-29$

CNAE 2.0 principal: $29.30-1-02$

Descrição da CNAE: Fabricação de carrocerias para ônibus

Correspondências possíveis da CNAE 1.0:

CNAE 1: $34.31-2$

Descrição CNAE 1: Fabricação de cabines, carrocerias e reboques

para caminhão

CNAE 2: $34.32-0$

Descrição CNAE 2: Fabricação de carrocerias para ônibus

CNAE 3: $34.39-8$

Descrição CNAE 3: Fabricação de cabines, carrocerias e reboques

para outros veículos

Conclusão: comparando-se a descrição da CNAE optou-se pela

corres pondência com a CNAE 1.0 código 34.32-0, que pertence ao grupo

343 e à classe 3432.

No Quadro 6, vê-se que a empresa Marcopolo possui o código CNAE, pela versão 2.0, igual a 29.30-1-02, cuja atividade econômica associada é a de "Fabricação de carrocerias para ônibus". A correspondência com a versão CNAE 1.0 permite fazer associação com três códigos: i) 34.31.2; ii) 34.32-0; iii) 34.39-8 ${ }^{39}$. No entanto, verifica-se que o código 34.32-0 é o único que possui a descrição igual à da versão CNAE $2.0^{40}$. Assim, esse é o código correto para associação. Para as demais empresas, o mesmo procedimento foi seguido ${ }^{41}$.

\subsubsection{Desempenho}

Conforme afirmam Bhagat e Jefferis (2002, p. 36), grande parte da literatura utiliza métricas de desempenho baseadas em dados contábeis, como retorno sobre o capital e indicadores de

\footnotetext{
${ }^{39}$ Vale ressaltar que nesse caso específico não haveria prejuízo se o interesse fosse apenas na CNAE ao nível do grupo, pois os três códigos pertencem ao grupo 343. Todavia, quando se analisa as classes, vê-se que haveria problemas, pois os códigos correspondem a três classes distintas.

${ }^{40} \mathrm{Na}$ verdade, a descrição é uma forma simplificada de explicar como foi feita a associação. Esse problema surge pelo fato de a tabela de correspondência apresentar os códigos de ambas as versões da CNAE até o quarto nível, classe. Se a tabela de correspondência fosse feita até o quinto nível, subclasse, não haveria o problema de duplicidade. No caso acima, a descrição "Fabricação de carrocerias para ônibus" é definida pela subclasse "02" do código 29.30-1-02.

${ }^{41}$ No Apêndice 1 há uma lista desses casos.
} 
mercado, como o Q de Tobin. Os autores citam ainda que os indicadores baseados em dados do mercado incluem o retorno das ações em um período de tempo específico.

Segundo Bhagat e Jeferris (2002), se o mercado acionário for eficiente na forma semi-forte, então o mercado antecipará e incorporará nos preços das ações quaisquer alterações nas práticas de governança corporativa da companhia, portanto os estudos não conseguiriam identificar relações significantes entre mecanismos de governança e desempenho das ações no mercado acionário.

Em relação ao Q de Tobin, Bhagat e Jeferris (2002) sugerem que tal métrica não está sujeita aos problemas de antecipação, no entanto pode ter seu cálculo enviesado por outros dois motivos. O primeiro refere-se à subavaliação do denominador da equação, ativo total, em função de as firmas poderem ter grande parte de sua riqueza criada por meio de ativos intangíveis, que em diversas ocasiões não são registrados nas demonstrações contábeis, e, portanto, não são incluídos no numerador da equação. O segundo refere-se ao fato de que um Q de Tobin elevado pode ser devido a um grande poder de mercado da companhia. Portanto, quaisquer associações entre um elevado Q de Tobin e outras variáveis podem apresentar resultado significativo, porém em função de uma correlação espúria, causada pela omissão da variável "poder de mercado".

Em referência às métricas de desempenho baseadas em dados contábeis, Bhagat e Jefferis (2002) afirmam que não estão sujeitas aos problemas de antecipação e nem são afetadas por mudanças no "humor" dos agentes de mercado. No entanto, são afetadas pela discricionaridade no tratamento de alguns eventos contábeis.

Das abordagens apresentadas, na pesquisa serão utilizados o Q de Tobin e métricas baseadas em dados contábeis ${ }^{42}$ como aproximações para identificar o desempenho das companhias.

O Q de Tobin foi operacionalizado por meio da aproximação proposta por Chung e Pruitt (1994). Nesta aproximação, a equação de cálculo é a seguinte: Soma do valor de mercado das

\footnotetext{
${ }^{42} \mathrm{O}$ retorno das ações não será utilizado como métrica para desempenho em razão do potencial problema da antecipação no reconhecimento de eventos. Os trabalhos de Barber e Lyon (1996), Kothari e Warner (1997) e Bhagat e Jefferis (2002) tomados em conjunto justificam a exclusão dessa possibilidade.
} 
ações ordinárias (VMAO), valor de mercado das ações preferenciais (VMAP), valor contábil da dívida (VCD). O resultado desta soma é dividido pelo ativo total da companhia (AT). A equação abaixo representa o cálculo:

$$
\text { QdeTobin }=\frac{V M A O+V M A P+D I V T}{A T}
$$

Em relação às métricas baseadas exclusivamente em informações contábeis, especificamente serão utilizadas três: i) Lucro Operacional Próprio sobre Ativo Total (EBIT_AT); ii) Geração Bruta de Caixa sobre Ativo Total (EBITDA_AT); e iii) lucro antes de juros, imposto de renda, depreciação e amortização sobre a receita operacional líquida (EBITDA_REC).

O EBIT_AT é definido pela seguinte equação:

$$
\text { EBIT_AT }=\frac{\text { Lucro Operacional Próprio }}{\text { Ativototal }}
$$

Em que o Lucro Operacional Próprio é o lucro operacional antes das receitas e despesas financeiras. Essa medida é empregada como aproximação do retorno sobre o ativo da companhia.

A geração bruta de caixa, EBITDA_AT, é dada pela equação a seguir:

$$
E B I T D A_{-} A T=\frac{\text { Lucro antes de juros, imposto de renda, depreciação eamortização }}{\text { Ativototal }}
$$

Por fim, EBITDA_REC, uma métrica de rentabilidade, é definida pela seguinte equação:

$$
\text { EBITDA_REC }=\frac{\text { Lucro antes de juros, imposto de renda, depreciação e amortizaçã }}{\operatorname{Re} \text { ceita Operacional Líquida }}
$$


As duas primeiras aproximações para o desempenho, EBIT_AT e EBTIDA_AT, foram extraídas do trabalho de Silveira (2004). A última, EBITDA_REC, teve como inspiração principal a pesquisa de Giroud e Mueller (2008).

A utilização de diferentes proxies para a variável de desempenho objetiva aumentar a robustez dos resultados, sejam significativos ou não.

\subsection{Variáveis de controle}

Pelo fato de diversos outros atributos poderem influenciar a estrutura de governança da companhia e desempenho, além das três variáveis discutidas na seção precedente, também será incluída nas regressões uma série de variáveis de controle comumente utilizadas na literatura de governança corporativa, como possíveis determinantes da estrutura de governança da companhia e desempenho da companhia. Para a definição das variáveis de controle, foram levados em consideração os trabalhos de Black et al. (2009), Silveira et al. (2007), Brown e Caylor (2006), Durnev e Kim (2005), Silveira (2004), Leal e Carvalhal-daSilva (2005), Klapper e Love (2002) e Gompers et al. (2003). Abaixo são apresentadas as variáveis de controle e suas respectivas definições operacionais.

\subsubsection{Estrutura de propriedade}

As variáveis de estrutura de propriedade foram extraídas trabalho de Leal e Carvalhal-da Silva (2005). As duas principais aplicadas na pesquisa são:

i) Direito de controle pelos maiores acionistas, mensurado pelo percentual de ações ordinárias em posse dos três maiores acionistas (3VDIR); e

ii) Percentual de ações ordinárias em relação ao total de ações, mensurado pela divisão do número de ações ordinárias pelo número total de ações (VOTE). 


\subsubsection{Identidade do acionista controlador}

O tipo de controlador foi identificado por meio de variáveis binárias, dividido em cinco categorias: i) Familiar (IDENT_1); ii) Estatal (IDENT_2); iii) Controle compartilhado (IDENT_3); iv) Estrangeiro (IDENT_4); e v) Disperso (IDENT_5). Identificação semelhante é utilizada por Silveira et al. (2007), no entanto na classificação dos autores não há a quinta categoria, controle disperso.

\subsubsection{Estrutura de Capital}

A estrutura de capital (LEV) será estimada como a razão entre dívida total e ativo total da companhia, no final de cada ano. Durnev e Kim (2005) utilizam tal variável como controle.

\subsubsection{Oportunidades futuras de crescimento}

As oportunidades futuras de crescimento (CRESC) foram mensuradas pelo crescimento acumulado das vendas dos últimos três exercícios. Gompers et al. (2003) e Durnev e Kim (2005) utilizam métrica semelhante em seus estudos.

\subsubsection{Níveis diferenciados de governança da BM\&FBOVESPA}

Foi mensurada por meio de uma variável binária. Se a companhia for listada no Nível II ou Novo Mercado da BM\&FBOVESPA, atribuiu-se o valor 1 à variável. Caso a companhia seja listada no segmento tradicional ou no Nível I, foi atribuído o valor 0. A sigla da variável será N2NM. Um dos estudos que utiliza tal variável é o de Silveira (2004).

\subsubsection{Emissão de American Depositary Receipts (ADRs)}

Será mensurada por uma variável binária que indicará se a companhia emite ADRs níveis II ou III. Esses dois tipos de ADRs foram submetidos às exigências da Lei Sarbanes \& Oxley, promulgado em 2002 pelos EUA. Portanto, a companhia sujeita-se a uma série de exigências que tendem a elevar seu nível de governança. Caso a empresa emita ADRs em um desses 
níveis, a variável assumirá valor 1 . Na situação em que a companhia não emita ADRs nessa categoria, a variável assumirá o valor 0. A sigla da variável será ADR23. Entre outros estudos, essa variável é utilizada no estudo de Black et al. (2009).

\subsubsection{Tangibilidade}

A tangibilidade da operação (TANG) será mensurada pelo ativo imobilizado bruto sobre a receita operacional líquida. Silveira (2004) utiliza essa métrica como uma das variáveis de controle do seu estudo.

\subsubsection{Tamanho}

O tamanho da firma (SIZE) será medido pelo logaritmo natural da receita operacional líquida. Tal variável de controle é utilizada por Klapper e Love (2002).

\subsubsection{Idade da firma}

A idade da firma (AGE) será mensurada pelo número de anos da fundação da companhia (AGE). Brown e Caylor (2006) utilizam essa variável no estudo deles.

\subsubsection{Dividend yeld}

Definido como dividendos e demais rendimentos da ação pagos por ação sobre o preço da ação (DIVYELD), ambos medidos no final do exercício. Silveira et al. (2007) utilizam essa variável em seu estudo.

\subsubsection{Setor de atuação}

O setor de atuação (IND) foi definido com base na classificação do sistema Economática. A classificação do Economática possui 20 setores, todavia apenas 13 estão representados na 
amostra da pesquisa. Na subseção 4.1, estatísticas descritivas, são apresentadas informações acerca dos setores utilizados na pesquisa.

\subsubsection{Resumo das variáveis do estudo}

Todas as variáveis utilizadas no estudo estão resumidas no Quadro 7:

\begin{tabular}{|c|c|c|c|}
\hline Código & Nome da variável & Definição operacional & Fonte/Estudo-base \\
\hline IGOV & Índice de governança corporativa & $\begin{array}{l}\text { Questionário composto por } 20 \text { vinte } \\
\text { perguntas. Pontuação varia entre } 0 \text { e } 20 .\end{array}$ & IBGC \\
\hline HHI_3 & $\begin{array}{l}\text { Índice de Herdindahl-Hirschmann } \\
\text { calculado pela CNAE a três dígitos }\end{array}$ & $\begin{array}{l}\text { Calculado pela soma da participação de } \\
\text { mercado ao quadrado das n firmas } \\
\text { pertencentes a CNAE a três dígitos. } \\
\text { Para calcular a participação de mercado, } \\
\text { a receita bruta da companhia foi dividida } \\
\text { pela receita total da CNAE a três dígitos. }\end{array}$ & \\
\hline HHI_4 & $\begin{array}{l}\text { Índice de Herdindahl-Hirschmann } \\
\text { calculado pela CNAE a quatro } \\
\text { dígitos }\end{array}$ & $\begin{array}{l}\text { Calculado pela soma da participação de } \\
\text { mercado ao quadrado das n firmas } \\
\text { pertencentes a CNAE a quatro dígitos. } \\
\text { Para calcular a participação de mercado, } \\
\text { a receita bruta da companhia foi dividida } \\
\text { pela receita total da CNAE a quatro } \\
\text { dígitos. }\end{array}$ & \\
\hline C4_3 & $\begin{array}{l}\text { Razão de concentração calculada } \\
\text { pela CNAE a três dígitos }\end{array}$ & $\begin{array}{l}\text { Calculado pela soma da participação de } \\
\text { mercado das quatro primeiras empresas } \\
\text { pertencentes a CNAE a três dígitos. } \\
\text { Para calcular a participação de mercado, } \\
\text { a receita bruta da companhia foi dividida } \\
\text { pela receita total da CNAE a três dígitos. }\end{array}$ & IBGE \\
\hline NCOMP_3 & $\begin{array}{l}\text { Número de competidores pela } \\
\text { CNAE a três dígitos }\end{array}$ & $\begin{array}{l}\text { Corresponde ao número de } \\
\text { competidores presentes emummercado, } \\
\text { definido pela CNAE a três dígitos, e } \\
\text { utilizados no cálculo do HHI a três } \\
\text { dígitos. }\end{array}$ & \\
\hline NCOMP_4 & $\begin{array}{l}\text { Número de competidores pela } \\
\text { CNAE a quatro dígitos }\end{array}$ & $\begin{array}{l}\text { Corresponde ao número de } \\
\text { competidores presentes emum mercado, } \\
\text { definido pela CNAE a quatro dígitos, e } \\
\text { utilizados no cálculo do HHI a quatro } \\
\text { dígitos. }\end{array}$ & \\
\hline EBITDA_AT & Geração bruta de caixa & $\begin{array}{l}\text { Mensurado pela divisão do lucro } \\
\text { operacional próprio pelo ativo total. } \\
\text { Mensurado pela divisão do lucro antes } \\
\text { dos juros, impostos, depreciação e } \\
\text { amortização sobre o ativo total. }\end{array}$ & $\begin{array}{l}\text { Silveira (2004) e Giroud e } \\
\text { Mueller (2008) }\end{array}$ \\
\hline
\end{tabular}


Quadro 7 - Resumo das variáveis do estudo (continuação)

\begin{tabular}{|c|c|c|c|}
\hline Código & Nome da variável & Definição operacional & Fonte/Estudo-base \\
\hline EBITDA_REC & Margem EBITDA & $\begin{array}{l}\text { Mensurado pela divisão do lucro antes } \\
\text { dos juros, impostos, depreciação e } \\
\text { amortização sobre receita operacional } \\
\text { líquida. }\end{array}$ & \\
\hline QTOBIN & Q de Tobin & $\begin{array}{l}\text { Soma do valor de mercado das ações } \\
\text { ordinárias (VMAO), valor de mercado } \\
\text { das ações preferenciais (VMAP), valor } \\
\text { contábil da dívida (VCD). O resultado } \\
\text { desta soma é dividido pelo ativo total da } \\
\text { companhia (AT). }\end{array}$ & $\begin{array}{l}\text { Silveira (2004) e Giroud e } \\
\text { Mueller (2008) }\end{array}$ \\
\hline 3VDIR & $\begin{array}{l}\text { Direito de controle dos três } \\
\text { maiores acionistas }\end{array}$ & $\begin{array}{l}\text { Percentual de ações ordinárias dos três } \\
\text { maiores acionistas em relação ao } \\
\text { montante de ações ordinárias. }\end{array}$ & \multirow{2}{*}{$\begin{array}{l}\text { Leal e Carvalhal-da-Silva } \\
\text { (2005) }\end{array}$} \\
\hline VOTE & $\begin{array}{l}\text { Percentual de ações com direito a } \\
\text { voto }\end{array}$ & $\begin{array}{l}\text { Total de ações ordinárias dividido pelo } \\
\text { total de ações ordinárias e preferenciais. }\end{array}$ & \\
\hline IDENT_1 & & $\begin{array}{l}\text { Último acionis ta é controlador é uma } \\
\text { família. }\end{array}$ & \multirow{5}{*}{ Silveira et al. (2007) } \\
\hline IDENT_2 & & $\begin{array}{l}\text { Último acionis ta é controlador é o } \\
\text { Estado. }\end{array}$ & \\
\hline IDENT_3 & $\begin{array}{l}\text { Identidade do acionis ta } \\
\text { controlador }\end{array}$ & $\begin{array}{l}\text { Último acionista é controlador é um } \\
\text { grupo de empresas que possui acordo } \\
\text { de acionistas. }\end{array}$ & \\
\hline IDENT_4 & & $\begin{array}{l}\text { Último acionista controlador é um grupo } \\
\text { ou investidor estrangeiro. }\end{array}$ & \\
\hline IDENT_5 & & $\begin{array}{l}\text { Último acionis ta é controlador não pode } \\
\text { ser identificado. }\end{array}$ & \\
\hline LEV & Estrutura de capital & $\begin{array}{l}\text { Dívida total dividida pelo ativo total da } \\
\text { empresa. }\end{array}$ & Durnev e Kim (2005 \\
\hline CRESC & Crescimento das vendas & $\begin{array}{l}\text { Crescimento percentual acumulado de } \\
\text { vendas dos últimos três exercícios } \\
\text { sociais, em termos reais. }\end{array}$ & $\begin{array}{l}\text { Gompers et al. (2003) e } \\
\text { Durnev e Kim (2005) }\end{array}$ \\
\hline $\mathrm{N} 2 \mathrm{NM}$ & $\begin{array}{l}\text { Lis tagem no Nível } 2 \text { ou Novo } \\
\text { Mercado }\end{array}$ & $\begin{array}{l}\text { Variável binária que indica se a empresa } \\
\text { pertence ou não aos segmentos de } \\
\text { lis tagem Nível } 2 \text { ou Novo Mercado. }\end{array}$ & Silveira (2004) \\
\hline ADR & Emissão de ADRs níveis 2 e 3 & $\begin{array}{l}\text { Variável binária que indica se a empresa } \\
\text { emite ou não ADRs níveis } 2 \text { ou } 3 .\end{array}$ & Black et al. (2009) \\
\hline TANG & Tangibilidade da operação & $\begin{array}{l}\text { Ativo imobilizado bruto sobre a receita } \\
\text { operacional líquida. }\end{array}$ & Silveira (2004) \\
\hline SIZE & Tamanho da empresa & Logaritmo natural da receita líquida. & Klapper e Love (2002) \\
\hline AGE & Idade da firma & $\begin{array}{l}\text { Número de anos desde a fundação até } \\
\text { os respectivos anos em análise. }\end{array}$ & Brown e Caylor (2006) \\
\hline DIVYELD & Rendimento dos dividendos & $\begin{array}{l}\text { Valor dos dividendos por ação dividido } \\
\text { pelo preço da ação. }\end{array}$ & \multirow{3}{*}{ Silveira et al. (2007) } \\
\hline IND & Setor de atuação da firma & $\begin{array}{l}\text { Classificação setorial baseada no } \\
\text { sistema Economática. }\end{array}$ & \\
\hline YEAR & Dummies de tempo & $\begin{array}{l}\text { Dummies de tempo } \operatorname{YEAR}(t) \text { definida } \\
\text { como } \operatorname{YEAR}(t)=1 \text { no ano } t \text { e } \operatorname{YEAR}(t)=0 \\
\text { nos demais casos, com } \mathrm{t}=1,2 \text { e } 3(2005, \\
2006 \text { e 2007) }\end{array}$ & \\
\hline
\end{tabular}




\subsection{População, amostragem e coleta dos dados}

Para a definição da amostra da pesquisa, partiu-se do total de empresas analisadas pelo IBGC. Assim, iniciou-se com um total de 1.191 observações, entre os anos de 2005 e 2008. Contudo, como a PIA-Empresa só está disponível até 2007, as observações do ano de 2008 foram excluídas, restando 854 observações. Após a coleta do CNPJ e CNAE, foi aplicado mais um filtro para definir a amostra final. Excluíram-se as empresas que não pertenciam às indústrias extrativas e de transformação ${ }^{43}$. Após este filtro, sobram 424 observações. Em seguida, foram excluídas as empresas que foram incorporadas, fundiram-se com outras empresas ou deixaram de operar ${ }^{44}$, além das companhias em que o CNPJ não foi identificado. Após a exclusão dessas empresas restaram 354 observações. Das 354 observações, 138 observações não apresentaram todas as variáveis para o processo de estimação por meios das regressões. Assim, a pesquisa possui 216 observações, que representam 90 empresas, em um período de três anos, de 2005 a 2007. Na tabela 2, tem-se a decomposição da amostra final do estudo:

Tabela 2 - Amostra do estudo

\begin{tabular}{|l|c|}
\hline Total de observações & $\mathbf{1 . 1 9 1}$ \\
\hline (-) observações do ano de 2008 & 337 \\
\hline (=) subtotal 1 & $\mathbf{8 5 4}$ \\
\hline (-) observações de setores não abrangidos pela PIA & 430 \\
\hline (=) subtotal 2 & $\mathbf{4 2 4}$ \\
\hline (-) observações incorporadas, que fundiram-se e que deixaram de operar & 70 \\
\hline (=) subtotal 3 & $\mathbf{3 5 4}$ \\
\hline (-) observações sem todas as variáveis disponíveis para as regressões & 138 \\
\hline (=) Amostra final (90 companhias, entre 2005 e 2007) & $\mathbf{2 1 6}$ \\
\hline
\end{tabular}

Da Tabela 2, vale ressaltar que trata-se de uma amostragem não probabilística, portanto os resultados da pesquisa ficarão restritos à amostra. O período principal da pesquisa é entre 2005 e 2007. Todavia, foram feitos testes adicionais para o período de 1998 e 2004, a fim de verificar a robustez dos resultados.

Em relação à coleta de dados, o Quadro 8 apresenta as fontes nas quais os dados da pesquisa foram coletados:

\footnotetext{
${ }^{43}$ A identificação dessas empresas foi feita pela CNAE.

${ }^{44} \mathrm{O}$ motivo de excluir essas companhias é porque a página da Receita Federal não permite obter informações sobre a CNAE das companhias que passaram por uma das situações citadas. Portanto, esse fato inviabiliza a coleta da CNAE, que no contexto da pesquisa é uma informação fundamental.
} 
Quadro 8 - Fontes de coleta de dados

\begin{tabular}{|c|c|}
\hline Fonte & Informação coletada \\
\hline BOVESPA & $\begin{array}{l}\text { - Segmento de listagem da companhia no Novo Mercado ou } \\
\text { Nivel II (N2NM) }\end{array}$ \\
\hline CONCLA & - Tabela de correspondência entre CNAE 1.0 e 2.0 \\
\hline \multirow{3}{*}{ CVM } & $\begin{array}{l}\text { - Identifidade do acionista controlador (FAM, SOE, SBH, } \\
\text { FOR PULV) }\end{array}$ \\
\hline & - Cadastro Nacional da Pes soa Jurídica (CNPJ) \\
\hline & - Empresas com emissões de ADRs II e III \\
\hline \multirow{10}{*}{ Economática } & - Retorno sobre ativo (ROA) \\
\hline & - Retorno sobre PL (ROE) \\
\hline & - Margem líquida (NPM) \\
\hline & - Variáveis do Q de Tobin (QTOBIN) \\
\hline & $\begin{array}{l}\text { - Variáveis de es trutura de propriedade (3VDIR, 3TDIR, } \\
\text { WEDGE3, VOTE) }\end{array}$ \\
\hline & - Estrutura de capital (LEV) \\
\hline & $\begin{array}{l}\text { - Receita para o cálculo do cres cimento das vendas } \\
\text { (GROWTH) }\end{array}$ \\
\hline & $\begin{array}{l}\text { - Receita líquida para o cálculo do tamanho da empresa } \\
\text { (LOGREC) }\end{array}$ \\
\hline & - Rendimento dos dividendos (DIVYELD) \\
\hline & - Setor de atuação da firma (IND) \\
\hline IBGC & - Índice de Governança Corporativa (IGOV) \\
\hline \multirow{3}{*}{ IBGE } & - Índice de Herfindahl-Hirschman (HHI) \\
\hline & - Razão de concentração (C4) \\
\hline & - Número de competidores \\
\hline $\begin{array}{l}\text { NYSE e Bank of } \\
\text { New York }\end{array}$ & - Empresas com emissões de ADRs II e III (ADR23) \\
\hline Receita Federal & - Classifcação Nacional das Atividades Econômicas (CNAE) \\
\hline $\begin{array}{l}\text { Website da } \\
\text { companhia }\end{array}$ & - Idade da companhia (AGE) \\
\hline
\end{tabular}

Em síntese, foram utilizadas dez diferentes fontes de dados para a consecução da pesquisa: BM\&FBOVESPA; CONCLA; CVM; Economática; IBGC; IBGE; NYSE; Bank of New York, Receita Federal do Brasil; e websites das companhias. 


\subsection{Modelos, tratamento estatístico e análise de dados}

Para responder às questões de pesquisas apresentadas em 1.3, dividiu-se a pesquisa em duas partes inter-relacionadas. A primeira parte investiga se a competição no mercado de produtos afeta significativamente a qualidade de governança corporativa das companhias. Na segunda parte, investiga-se se a interação entre competição no mercado de produtos e qualidade da governança corporativa afeta significativamente o desempenho das companhias.

Foram extraídas conclusões preliminares por meio de estatísticas descritivas, correlações e testes de diferenças de médias, este último procedimento adotado apenas na primeira parte da pesquisa. Em seguida, foram utilizadas análises de regressões com dados em painel, a fim de examinar a significância das relações estudadas. De acordo com Pindyck e Rubinfeld (2004, p. 288), um conjunto de dados em painel inclui uma amostra de entidades individuais ao longo de um período de tempo, característica presente na pesquisa, visto que são analisadas empresas por um período de três anos, entre 2005 e 2007. Ademais, vale salientar que a os dados constituem-se de um painel desbalanceado. Quanto à utilidade do método, Pindyck e Rubinfeld (2004, p. 288) explicam que essa forma de analisar os dados permite identificar e analisar efeitos econômicos que não poderiam ser identificados e analisados por meio do uso de dados em corte transversal ou apenas com o uso de séries temporais ${ }^{45}$.

Segundo Fávero et al. (2009, p. 382), a análise por meio dados em painel possui três abordagens: pooled ordinary least squares (POLS), efeitos fixos (EF) e efeitos aleatórios (EA).

A primeira abordagem, POLS, é uma regressão normalmente utilizada, levando em consideração o período de tempo de forma única. Abaixo são apresentadas as formas gerais dos modelos utilizados na pesquisa. Inicialmente, os modelos foram estimados pelo método dos Mínimos Quadrados Ordinários (MQO).

$$
\mathbf{I G O V}_{\mathrm{it}}=\alpha_{+} \beta_{\mathrm{t}}^{\prime} \mathbf{C O M P}_{\mathrm{it}+} \gamma_{\mathrm{t}}^{\prime} \mathbf{X}_{\mathrm{it}}+\psi^{\prime} \mathbf{A N O}_{\mathrm{t}}+\varepsilon_{\mathrm{it}}
$$

\footnotetext{
${ }^{45}$ Em Gujarati (2006, p. 514) e Hsiao (2005), são apresentadas diversas vantagens em utilisar regressões com dados em painel.
} 
No modelo 1 acima, IGOV representa a variável de governança corporativa definida em 3.2.1, COMP representa as variáveis de competição definidas em 3.2.2, $\mathbf{X}$ é o vetor das variáveis de controle apresentadas em 3.3,ANO representa variáveis binárias para cada ano da amostra, $i$ é o subscrito que indica a observação individual, $t$ é o subscrito de tempo, $\alpha$ é o intercepto, $\beta, \gamma$ e $\psi$ representam os coeficientes angulares e $\varepsilon$ representa o termo de erro aleatório.

O modelo 1 foi estruturado, principalmente, com base nos trabalhos de Chou et al. (2008) e Karuna (2008) e foi utilizado para estudar se a competição no mercado de produtos afeta significativamente a qualidade de governança corporativa das companhias brasileiras com ações listadas na BMF\&BOVESPA e pertencentes aos setores analisados pela PIA-Empresa do IBGE. O modelo foi analisado ao nível da firma ${ }^{46}$. As variáveis de competição no mercado de produtos, representadas pelo HHI, C4 e número de competidores, foram utilizadas nas regressões por meio de seus valores obtidos a três e quatro dígitos da $\mathrm{CNAE}^{47}$, mediante a disponibilidade de dados por período.

O modelo 2, apresentado abaixo, foi utilizado para estimar a relação proposta pela segunda questão da pesquisa.

DESEMP $_{\mathrm{it}}=\alpha_{+}$IGOV $_{\mathrm{it}+} \operatorname{COMP}_{\mathrm{it}}+\beta_{\mathrm{t}}^{\prime}\left(\mathrm{IGOV}_{\mathrm{it}} \mathrm{X} \mathbf{C O M P}_{\mathrm{it}}\right)_{+} \gamma_{\mathrm{t}}^{\prime} \mathbf{X}_{\mathrm{it}}+\psi^{\prime} \mathrm{ANO}_{\mathrm{t}}+\varepsilon_{\mathrm{it}}$

Neste modelo, DESEMP representa as variáveis de desempenho definidas em 3.2.3, IGOV representa a estrutura de governança corporativa definida em 3.2.1, COMP corresponde às variáveis de competição definidas em 3.2.2, todavia aqui representadas por meio de variáveis binárias, como abaixo explicado, $\mathbf{I G O V}_{\text {it }}$ X $\mathbf{C O M P}_{\text {it }}$ representa a interação entre governança corporativa e variáveis binárias indicativas de competição no mercado de produtos, $\mathbf{X}$ é o vetor das variáveis de controle apresentadas em 3.3, ANO representa variáveis binárias para cada ano da amostra, $i$ é o subscrito que indica a observação individual, $t$ é o subscrito de tempo, $\alpha$ é o intercepto, $\beta, \gamma$ e $\psi$ representam os coeficientes angulares e $\varepsilon$ representa o termo de erro aleatório.

\footnotetext{
${ }^{46}$ Em razão da abordagem setorial adotada e do tamanho da amostra, não foi possível utilizar regressões ao nível da indústria.

47 Karuna (2008) também utiliza um índice de concentração ao nível da indústria em seu trabalho.
} 
A inclusão de um termo de interação, como apresentado no modelo 2, é adequado para o propósito da pesquisa. Em Friedrich (1982), tem-se sólida argumentação em prol da utilização de modelos com termos de interação quando os problemas de pesquisas assim os requererem. Brambor et al. (2005, p. 64) explicam que os pesquisadores poderiam incluir termos de interação em seus modelos se tiverem uma hipótese condicional, ou seja, se, por exemplo, suporem que um aumento da variável $\mathrm{X}$ é associado com um aumento em Y quando $\mathrm{Z}$ está presente, mas não quando $\mathrm{Z}$ está ausente. Nesta parte da dissertação, investiga-se se o efeito da qualidade de governança corporativa das companhias varia conforme o grau de competição em seu respectivo setor de atuação. Logo, tem-se uma hipótese condicional que necessita da inclusão de um termo de interação no modelo empírico para que a resposta seja obtida. Hardy (1993, p. 30) apresenta motivos para que a interação entre variáveis seja utilizada. Segundo a autora, uma variável independente $\left(\mathrm{X}_{\mathrm{i}}\right)$ pode afetar de forma diferenciada a variável dependente $\left(\mathrm{Y}_{\mathrm{i}}\right)$ por meio de grupos ou o valor uma segunda variável independente $\left(\mathrm{Z}_{\mathrm{i}}\right)$. Nesses casos, quando o relacionamento entre $\mathrm{X}_{\mathrm{i}}$ e $\mathrm{Y}_{\mathrm{i}}$ depende de uma variável $\mathrm{Z}_{\mathrm{i}}$, o modelo de regressão deve ser ajustado para acomodar o efeito da interação entre variáveis. Logo, os autores coadunam em suas explanações e a inclusão de um termo de interação para responder à segunda questão de pesquisa do estudo é justificada.

O modelo 2 foi estruturado com base nos trabalhos de Giroud e Mueller (2008), Ammann et al. (2010) e Kadyrzhanova e Rhodes-Kropf (2007). Nestes trabalhos, os autores investigam o efeito diferencial das práticas de governança corporativa sobre o desempenho das companhias em função do grau de competição no setor de atuação. Para operacionalizarem as pesquisas, criam variáveis binárias com base na distribuição empírica das aproximações de competição utilizadas e as interagem com as variáveis de governança. Giroud e Mueller (2008) criam três variáveis binárias para indicar o tercil de competição ao qual um determinado índice pertence, separando em baixa competição, moderada ou alta. Na pesquisa, adotou-se a abordagem empregada por Giroud e Mueller (2008) e construíram-se tercis para cada uma das três proxies. Para a construção desses tercis, levou-se em conta a distribuição total anual de cada uma das aproximações. Após obterem-se os tercis, foi possível separar as CNAEs e, como consequência, indicar o grau de competição a que as companhias componentes da amostra estavam submetidas em seus respectivos setores. Além do método empregado por Giroud e Mueller (2008), também separou-se os setores em competitivos e não competitivos por meio 
da mediana da distribuições das proxies de competição, como em alguns dos testes empíricos feitos por Kadyrzhanova e Rhodes-Kropf (2007) e Ammann et al. (2010).

Além da inserção de variáveis binárias para identificar o grau de competição obtidas por meio da distribuição dos dados, também foram utilizadas na pesquisa variáveis binárias construídas em função de pontos de corte adotados por órgãos de defesa da concorrência, como a seguir explicado.

O guia de análise de atos de concentração horizontais norte-americano ${ }^{48}$ divide o HHI em três regiões: i) abaixo de 1000, o mercado é pouco concentrado; ii) entre 1000 e 1800, a concentração é considerada moderada; e iii) acima de 1800, o mercado é considerado altamente concentrado $^{49}$. No Guia do CADE, aprovado pela Portaria Conjunta SEAE/SDE $n^{\circ}$ 50, não há menção explícita de que o CADE adote o HHI oficialmente nos atos de concentração, contudo a leitura de alguns atos analisados pelo Órgão permite identificar seu uso corriqueiro. Gama e Ruiz (2005, p. 4-5) reforçam esse argumento, ao afirmarem que o CADE adota a regra do guia norte-americano, apresentada acima, para avaliar se um ato de concentração tem ou não o potencial de aumentar a probabilidade de exercícios de poder de mercado. Portanto, com base nas regiões definidas pelo guia norte-americano, criaram-se variáveis binárias para cada nível de $\mathrm{HHI}^{50}$.

Com relação à razão de concentração C4, no Guia do CADE (2001, p. 11) há menção de a SEAE e SDE considerarem que um ato de concentração gera controle suficiente para o exercício do poder de mercado quando o ato tornar a soma da participação de mercado das quatro maiores empresas igual ou superior a $75 \%$ ou a participação da empresa resultante do ato for igual ou superior a $10 \%$ do mercado relevante. Assim, com base no percentual de $75 \%$ para o C4, criou-se uma variável binária para indicar se um setor possui concentração acima ou abaixo desse valor. Caso o $\mathrm{C} 4$ seja maior do que $75 \%$, considera-se que o mercado é concentrado.

\footnotetext{
${ }^{48}$ Horizontal Merger Guidelines do Department of Justice (DOJ) e da Federal Trade Comission (FTC) foi aprovado em 1992 e revisado em 1997.

${ }^{49}$ A informação consta da página 18 do Guia.

${ }^{50}$ A utilização de um parâmetro definido em um mercado com características distintas no brasileiro é passível de diversas críticas. O trabalho de Gama e Ruiz (2005) apresenta algumas.
} 
Conforme Barros et al. (2009), os modelos 1 e 2 não captam variáveis que não são observadas pelo pesquisador, chamadas genericamente de heterogeneidade não-observada. Assim, se as variáveis observadas influenciarem de alguma forma a qualidade de governança corporativa da companhia, os coeficientes estimados serão inconsistentes. A fim de sanar esse problema, os modelos 1 e 2 foram reescritos da seguinte forma, respectivamente:

IGOV $_{\mathrm{it}}=\alpha_{\mathrm{t}+} \beta_{\mathrm{t}}^{\prime} \mathbf{C O M P}_{\mathrm{it}+} \gamma_{\mathrm{t}}^{\prime} \mathbf{X}_{\mathrm{it}}+\psi^{\prime} \mathbf{A N O}_{\mathrm{t}}+\eta_{\mathrm{i}}+\mu_{\mathrm{it}}$

$\operatorname{DESEMP~}_{\mathrm{it}}=\alpha_{\mathrm{t}+}$ IGOV $_{\mathrm{it}+} \operatorname{COMP}_{\mathrm{it}}+\beta_{\mathrm{t}}^{\prime}\left(\operatorname{IGOV}_{\mathrm{it}} \mathrm{x} \mathbf{C O M P}_{\mathrm{it}}\right)+\gamma_{\mathrm{t}}^{\prime} \mathbf{X}_{\mathrm{it}}+\psi^{\prime} \mathrm{ANO}_{\mathrm{t}}+\eta_{\mathrm{i}}+\mu_{\mathrm{it}}$

Nos modelos 3 e 4, o termo de erro $\varepsilon_{i t}$ foi decomposto em $\eta_{i}+\mu_{i t}$, sendo que $\eta_{i}$ representa a heterogeneidade não-observada e $\mu_{\text {it }}$ o termo de erro do modelo. Segundo Barros et al. (2009, p. 13), o termo $\eta_{\mathrm{i}}$ captura toda heterogeneidade não-observada associada à empresa $i$, desde que seja invariante ao longo do período analisado. Para a estimação dos parâmetros dos modelos 3 e 4, serão utilizados os procedimentos de EA e efeito fixos EF. Cameron e Trivedi (2009, p. 231) afirmam que no método de EF o termo $\eta_{\text {i }}$ pode ser correlacionado com os regressores do modelo. Ainda segundo os autores, pelo método de EA o termo $\eta_{\mathrm{i}}$ é assumido como sendo puramente aleatório, implicando que é totalmente não correlacionado com os regressores Em complemento, Wooldridge (2007, p. 434) afirma que para que os coeficientes gerados pelo estimador EF serem consistentes, é necessário que o erro idiossincrático $\mu_{\text {it }}$ seja não correlacionado com cada variável explicativa ao longo de absolutamente todos os períodos de tempo analisados. Em relação ao estimador EA, Wooldridge (2007, p. 440) afirma que todas as hipóteses do estimador EF devem ser satisfeitas, além de mais uma condição restritiva que é o fato de que $\eta_{i}$ seja independente de todas as variáveis explicativas, em todos os períodos de tempo.

\subsection{Diagnósticos dos modelos e estimadores robustos dos erros-padrão}

$\mathrm{Na}$ pesquisa, foram adotados métodos convencionalmente utilizados para a averiguação dos pressupostos dos modelos, a fim de identificar potenciais violações e, por conseguinte, métodos de correção adequados. 
O teste de Breusch-Pagan foi utilizado para testar a homocedasticidade dos resíduos. Com relação à autocorrelação serial dos resíduos, aplicou um teste robusto específico para a identificação de presença de autocorrelação em modelos lineares de dados em painel desenvolvido por Wooldridge (2002) ${ }^{51}$. A multicolinearidade foi estudada por meio do Fator de Inflação da Variância (VIF), como sugerido por Field (2009, p. 183) e Hair et al. (2005, p. 167). No entanto, Gujarati (2006, p.280) e Wooldridge (2007, p. 93) afirmam que a presença de multicolinearidade não afeta a característica dos estimadores de MQO de serem os melhores estimadores lineares não tendenciosos. Os autores comentam que uma possível solução para tal problema é a exclusão das variáveis colineares, todavia advertem que a exclusão de uma variável pode gerar má especificação no modelo. Na pesquisa, as variáveis principais e de controle foram incluídas nos modelos conforme estudos específicos dos campos de pesquisa. Logo, a exclusão de variáveis que apresentem multicolinearidade pode prejudicar a correta especificação do modelo. Com relação ao pressuposto de normalidade, não obstante a realização de testes numéricos, a ausência de normalidade não invalida os resultados, conforme Wooldridge (2007, p. 163), em função de os estimadores de MQO satisfazerem a normalidade assimptótica.

Barros (2005) afirma que: "A estimação adequada de erros-padrão dos estimadores em pesquisas na área de finanças corporativas com dados em painel não é uma questão trivial”. O autor prossegue em sua explanação e afirma que os termos de erro de modelos estimados na área de finanças estão sujeitos à potencial heterocedasticidade temporal e à eventual dependência temporal, fatos que gerariam erros-padrão enviesados e inconsistentes, cujo resultado seria o prejuízos às inferências dos modelos.

Como forma de corrigir esses potenciais problemas, Barros (2005, p. 108) sugere a utilização do estimador de erros-padrão com dados agrupados (clustered standard errors). Esse procedimento não altera a forma como os coeficientes são estimados, pois apenas modifica os seus respectivos erros-padrão. O trabalho de Petersen (2005) é utilizado como sustentação teórica para os procedimentos sugeridos por Barros (2005). Em síntese, Petersen (2005) demonstra por meio de simulações que a utilização de modelos com variáveis binárias

\footnotetext{
${ }^{51}$ No artigo de Drukker (2003) há simulações para verificar a eficiência do teste, bem como sua implementação no software Stata por meio do comando "xtserial".
} 
indicativas de tempo em conjunto com a utilização de estimadores de erros-padrão agrupados por empresa simultaneamente lida com os problemas de heterocedasticidade e da possível correlação serial dos erros entre empresas e no tempo.

Dessa forma, para corrigir os potenciais problemas advindos da presença de heterocedasticidade e autocorrelação dos erros, nesta pesquisa foi seguido o tratamento indicado por Barros (2005, p. 108-109) e em todas as especificações foi utilizado o estimador de erros-padrão com dados agrupados por empresa, juntamente com variáveis binárias indicativas de ano.

Por fim, para identificar qual modelo se adapta melhor aos dados, são utilizados alguns testes estatísticos. Segundo Fávero et al. (2009, p. 383-384), entre o POLS e o modelo de EF, utiliza-se o teste de Chow, que representa um teste $\mathrm{F}$ e pode ser utilizado para determinar se os parâmetros de duas funções de regressão múltipla diferem entre si. Ainda segundo os autores, entre o modelo POLS e o EA, aplica-se o teste do multiplicador de Lagrange de Breusch-Pagan. Por fim, para decidir entre os modelos de EF e EA foi aplicada uma versão generalizada do teste de Hausman ${ }^{52}$. A opção por uma versão generalizada ao invés do tradicional teste aplicado em pesquisas se deve ao fato de que a versão generalizada pode ser implementada conjuntamente com a opção de erros-padrão agrupados (clustered erros) e também sempre retorna testes estatísticos estritamente positivos.

\subsection{Limitações do estudo}

As pesquisas empíricas relacionando governança corporativa, competição no mercado de produtos e desempenho potencialmente apresentam diversas limitações potenciais. Esta pesquisa não é diferente. Os trabalhos de Borsch-Supan e Koke (2000), Wintoki et al. (2008) e Barros et al. (2009) ajudam a elucidar as principais limitações da pesquisa.

\footnotetext{
52 A versão generalizada do teste de Hausman foi implementada no software Stata por Schaffer e Stillman (2006).
} 
A amostra de empresas e o período de tempo estudado são a primeira limitação da pesquisa. Ademais, Barros et al. (2009) elencam três causas fundamentais de problemas de endogeneidade presentes em pesquisas empíricas, que também limitam os resultados desta pesquisa, a saber: variáveis omitidas, erros de mensuração dos regressores e simultaneidade (ou causalidade reversa). Abaixo são discutidas especificamente cada uma dessas limitações.

\subsubsection{Amostra de empresas e período de tempo estudado}

O Quadro 2, apresentado na subseção 2.4.11, sumário dos estudos empíricos, é bastante útil para analisar a limitação da pesquisa com relação à amostra utilizada e o período de tempo.

Do Quadro, depreende-se que, em geral, os estudos utilizam amostras maiores para realizar inferências sobre o efeito da competição sobre a estrutura de governança das companhias ou para avaliar a interação entre as variáveis e o efeito sobre o desempenho. Na pesquisa, em razão da opção pelo cálculo do HHI por meio de uma base de dados que abarcasse o maior número de empresas possível e que incluísse no cálculo tanto empresas abertas quanto empresas fechadas, houve uma restrição dos setores analisados, limitando-se à indústria de transformação e extrativas, visto que são as indústrias contempladas pela PIA-Empresa do IBGE. Na Tabela 1, na qual há a decomposição da amostra do estudo, fica evidente a perda de observações em função de a PIA contemplar apenas o setor industrial. Na pesquisa, é utilizada uma amostra de 90 empresas, o que corresponde a 216 observações, restrita a um determinado segmento econômico. Borsch-Supan e Koke (2000, p. 15) expõem que as pesquisas realizada na Alemanha com foco na competição e que valem-se de índices de concentração como proxy estão sujeitas ao fato dos dados estarem disponíveis apenas para o setor industrial, desconsiderando-se dessa forma o setor de serviços e comércio, por exemplo. Tem-se o mesmo problema na presente pesquisa. Logo, as inferências estatísticas ficam prejudicadas, na medida em que a reduzida amostra tende a aumentar os erros-padrão das regressões, em função da perda de graus de liberdade nos testes estatísticos.

O período de três anos, 2005 a 2007, pode ser considerado reduzido quando comparado à pesquisas internacionais correlatas. Como evidência, Karuna (2007) utiliza em sua pesquisa um período de 12 anos (1992-2003), Chou et al. (2008) valem-se de um período de 16 anos 
(1990-2005) e Giroud e Mueller (20008) coletam dados para 17 anos (1990-2006). Em síntese, a amostra reduzida e o curto período podem não ser suficientes para estimar claramente a relação entre as variáveis.

\subsubsection{Variáveis omitidas}

Segundo Borsch-Supan e Koke (2000, p. 10), outro problema presente em estudos empíricos sobre governança corporativa ocorre quando variáveis explicativas relevantes estão ausentes dos modelos de regressões. Barros et al. (2009, p. 5) afirmam que, talvez, a omissão de variáveis simultaneamente correlacionadas com os regressores incluídos e com a variável de resposta seja a causa mais comum de endogeneidade em pesquisas empíricas.

Para mitigar essa limitação, na pesquisa é empregado um conjunto de variáveis de controle presentes em estudos sobre governança corporativa. Contudo, nem mesmo a utilização de variáveis de controle pode resolver o problema. De acordo com Barros et al. (2009, p. 5), o problema pode persistir se a variável ausente for intrinsecamente não mensurável ou se o pesquisador não dispuser de meio para mensurá-la. Como evidência prática, Silveira (2004, p. 118) relata que em sua pesquisa não foi possível coletar variáveis relevantes, como o percentual de ações em posse dos executivos e a remuneração de gestores, importantes mecanismos de governança, pois as companhias abertas no momento da pesquisa não eram obrigadas a publicar a forma nem os montantes da remuneração individual dos gestores e nem evidenciar os acionistas com menos de $5 \%$ de suas ações.

\subsubsection{Erros de mensuração dos regressores}

Barros et al. (2009, p. 6) explicam que em estudos com dados observacionais, supor que tanto a variável dependente quanto a variável independente possam ser mensuradas com erro é bastante razoável, tanto em função de erros de registro como pela disparidade entre um construto que se pretende observar e a variável utilizada como substituta, proxy, efetivamente disponível. 
Como apresentado na seção 3.2, há críticas quanto a adoção de índices amplos de governança corporativa como aproximação da estrutura de governança das companhias (BAGHAT et al., 2007), ao uso de índices de concentração como métrica de competição no mercado de produtos (BOONE, 2004) e à utilização de métricas contábeis e Q de Tobin (BHAGAT; JEFFERIS, 2002) como aproximações para desempenho. Pelo motivo de não haver consenso sobre quais métricas utilizar, há o potencial de tais variáveis serem calculadas com significativo grau de imprecisão, ocasionando um problema econométrico associado ao erro de mensuração das variáveis dependentes e independentes. Borsch-Supan e Koke (2000) e Barros et al. (2009) afirmam que erros de mensuração podem gerar inconsistências na estimação dos coeficientes das regressões. Coincidentemente, Borsch-Supan e Koke (2000, p. 23) utilizam as métricas de competição para exemplificar os problemas econométricos gerados pela imprecisa especificação das variáveis do estudo. Portanto, é possível que as proxies aplicadas nos testes empíricos apresentem erros de mensuração que possam afetar os resultados do estudo.

Especificamente com relação às métricas que servem como proxies para competição no mercado de produtos, cabem alguns comentários adicionais. A estrutura de mercado no qual uma firma opera possui várias características relevantes, entre as quais: i) barreiras a entrada; ii) barreiras a saída; iii) número de fornecedores; iv) número de clientes; v) existência de bens substitutos ou complementares; e iv) regulamentações específicas. Em conjunto, todas essas variáveis potencialmente determinam a competição em um determinado setor. No entanto, em virtude da impossibilidade de obter todas essas variáveis, a pesquisa acompanha diversos estudos realizados no exterior (GROSFELD; TRESSEL, 2001; CHOU et al., 2008; GIROUD; MUELLER, 2008, 2009) sobre este mesmo tema e utiliza apenas uma dimensão específica do mercado: o nível de concentração, por meio do HHI, C4 e número de competidores. Portanto, há possibilidade de que as diferentes métricas utilizadas não captem a efetiva competição entre empresas, dado que não consideram em seu cálculo a interação entre companhias. Sobre as limitações de métricas de competição no mercado de produtos, BorschSupan e Koke (2000, p. 24) comentam que mesmo se houvesse o conhecimento de todos os participantes de um mercado e as suas respectivas participações, ainda não seria suficiente para garantir o correto cálculo do grau de competição, visto que cada mercadoria produzida 
pelos participantes do mercado teriam diferentes mercadoria substitutas ${ }^{53}$ e isso influenciaria no nível de competição enfrentado por cada firma.

Ainda cabem ser salientadas outras duas últimas importantes limitações concernentes ao cálculo da competição no mercado de produtos. Primeiramente, os efeitos do comércio internacional não estão sendo computados no cálculo do HHI e C4. Carlton e Perloff (2000) citam essa limitação como uma possível fonte de viés das métricas de concentração. Ao não considerar as importações e exportações, é possível que os índices sejam calculados de forma superestimada ou subestimada, dependendo do caso. Em segundo lugar, as definições de mercado relevante adotadas, terceiro e quartos dígitos da CNAE, podem não contemplar o real mercado de operação da firma. Como exemplo, no trabalho de Januszewski et al. (2001) as variáveis que aproximam a competição no mercado de produtos não apresentaram significância estatística. Segundo os autores, possivelmente a definição imprecisa do conceito de mercado relevante levou a este resultado.

\subsubsection{Simultaneidade}

Barros et al. (2009, p. 7) e Borsch-Supan e Koke (2000, p. 3) abordam os potenciais efeitos negativos da simultaneidade (ou causalidade reversa) sobre estudos envolvendo governança corporativa. Segundo os autores, uma fonte comum de problemas de endogeneidade em pesquisas na área de finanças corporativas é a provável determinação simultânea de diversas variáveis. Uma eventual simultaneidade entre variáveis dependentes e independentes, de forma que ambas as variáveis possam ser consideradas dependentes e independentes um em relação à outra, gerará correlação entre o componente de erro e o regressor, cujo resultado é tornar os estimadores de $\beta$ enviesados e inconsistentes.

Borsch-Supan e Koke (2000, p. 7) consideram o emprego de dados em painel, principalmente pelos procedimentos de fixos e primeiras diferenças, úteis para mitigar problemas de causalidade reversa, tendo em vista que leva em consideração a heterogeneidade nãoobservada das companhias. Todavia, apesar de a utilização de dados em painel pelos procedimentos de EF, primeiras diferenças e EA corrigir alguns problemas econométricos,

\footnotetext{
${ }^{53}$ Vale citar que Karuna $(2007 ; 2008)$ é a única pesquisa analisada que utilizou uma aproximação para a idéia de "substitutibilidade".
} 
não consideram a potencial influência direta de valores passados da variável de resposta sobre os valores atuais. Barros et al. (2009) afirmam que este fato é conhecido como a retroalimentação da variável de resposta para os regressores. Na presença desse fenômeno, ainda segundo os autores, a suposição de exogeneidade estrita não é válida e os estimadores tradicionais de EF e EA tornam-se inconsistentes. Wintoki et al. (2008, p. 3) afirmam que o desempenho passado da firma é uma aproximação razoável para alguns fatores não observados e que podem influenciar o desempenho e a estrutura de governança corporativa correntes. Barros et al. (2009, p. 22) reforçam esse argumento e afirmam que diversas variáveis na área de finanças apresentam comportamento inercial, cujo resultado é que a utilização de modelos estáticos pode não ser adequada.

Portanto, é provável que as variáveis dependentes nas equações 7 e 8, estrutura de governança corporativa e desempenho, respectivamente, influenciem simultaneamente algumas das variáveis utilizadas como variáveis independentes. No estudo de Silveira et al. (2007, p. 15) os autores identificam problemas semelhantes aos da presente pesquisa e sugerem a utilização do GMM-Sys como forma de mitigar problemas de endogeneidade na ausência de instrumentos válidos realmente exógenos. Segundo Silveira et al. (2007, p. 17), a aplicação do GMM-Sys permite relaxar algumas premissas que são necessárias para estimar consistentemente os coeficientes em outros métodos, como EA e EF. Segundo Wintoki et al. (2008, p. 4), a aplicação de um painel dinâmico com coeficientes estimados pelo GMM mitiga os seguintes problemas econométricos: i) endogeneidade dinâmica; ii) heterogeneidade não-observada; e iii) simultaneidade. Portanto, conforme demonstrado nos trabalhos de Wintoki et al. (2008) e Barros et al. (2009) e aplicado no trabalho de Silveira et al. (2007), a utilização do GMM-Sys poderia ser de grande utilidade na estimação de coeficientes consistentes. Não obstante os potenciais benefícios da estimação por meio do GMM-Sys, na pesquisa foram utilizados apenas os tradicionais procedimentos de EF e EA, o que implica em análises cautelosas dos resultados da pesquisa.

Em complemento, o próprio cálculo do HHI pode apresentar problemas de endogeneidade. O trabalho de Demsetz (1973), por exemplo, aponta para a endogeneidade dos índices de concentração. Segundo o autor, a concentração de uma indústria é resultado de uma série de outros eventos. Portanto, a variável "competição no mercado de produtos", aproximada por índices de concentração, também pode ser endógena. O trabalho de Fulghieri e Suomini 
(2005), no qual os autores sugerem ser possível que a estrutura de governança influencia o grau de concentração, também justifica considerar a potencial endogeneidade das proxies de competição como uma limitação da pesquisa. 


\section{RESULTADOS DA PESQUISA}

\subsection{Estatísticas descritivas}

Inicialmente, são apresentadas as estatísticas descritivas das principais variáveis envolvidas na pesquisa. A tabela 3 apresenta informações sobre o IGOV e seus subíndices com todos os dados padronizados para variarem entre 0 e 10, de forma a facilitar a compreensão do comportamento dos índices ao longo do período.

Tabela 3 - Estatísticas descritivas da variável IGOV e subíndices.

\begin{tabular}{|c|c|c|c|c|c|c|c|}
\hline Ano & Variáveis & Média & Des vio-padrão & $1^{\circ}$ quartil & Mediana & $3^{\circ}$ quartil & Amostra \\
\hline \multirow{5}{*}{2005} & IGOV & 3.77 & 1.14 & 3.00 & 3.50 & 4.50 & 75 \\
\hline & DISC & 3.67 & 2.62 & 1.67 & 3.33 & 6.67 & 75 \\
\hline & BOARD & 4.91 & 2.24 & 4.00 & 4.00 & 6.00 & 75 \\
\hline & ETHIC & 1.93 & 1.82 & 0.00 & 2.50 & 2.50 & 75 \\
\hline & RGHTS & 4.17 & 1.34 & 4.00 & 4.00 & 5.00 & 75 \\
\hline \multirow{5}{*}{2006} & IGOV & 3.98 & 1.41 & 2.80 & 3.80 & 5.00 & 69 \\
\hline & DISC & 4.35 & 2.99 & 1.67 & 4.17 & 7.50 & 69 \\
\hline & BOARD & 5.36 & 2.24 & 4.00 & 6.00 & 6.00 & 69 \\
\hline & ETHIC & 1.27 & 1.75 & 0.00 & 1.25 & 1.25 & 69 \\
\hline & RIGHT & 4.20 & 1.61 & 4.00 & 4.00 & 5.00 & 69 \\
\hline \multirow{5}{*}{2007} & IGOV & 4.29 & 1.68 & 3.00 & 3.80 & 5.50 & 72 \\
\hline & DISC & 4.64 & 3.05 & 1.67 & 5.00 & 7.50 & 72 \\
\hline & BOARD & 5.53 & 2.39 & 4.00 & 6.00 & 8.00 & 72 \\
\hline & ETHIC & 1.68 & 1.97 & 0.00 & 1.25 & 1.25 & 72 \\
\hline & RIGHT & 4.60 & 1.93 & 4.00 & 4.00 & 6.00 & 72 \\
\hline \multirow{5}{*}{ Total } & IGOV & 4.01 & 1.43 & 3.00 & 3.80 & 5.00 & 216 \\
\hline & DISC & 4.21 & 2.91 & 1.67 & 3.33 & 7.50 & 216 \\
\hline & BOARD & 5.26 & 2.29 & 4.00 & 5.00 & 6.00 & 216 \\
\hline & ETHIC & 1.64 & 1.86 & 0.00 & 1.25 & 2.50 & 216 \\
\hline & RIGHT & 4.32 & 1.64 & 4.00 & 4.00 & 6.00 & 216 \\
\hline
\end{tabular}

A tabela contém as estatísticas descritivas do Índice de Governança Corporativa (IGOV) empregado na pesquisa. O IGOV é construído com base em um questionário composto por 20 questões, sendo 16 binárias, nas quais uma resposta positiva em relação ao que é tido como uma boa prática de governança corporativa representa um ponto adicional para a firma. Quatro questões apresentam pontuação intermediária (questões 1,2, 16 e 17): 0; 0,5 e 1. A pontuação mínima é 0 e a máxima 20. O IGOV é agrupado em quatro dimensões consideradas importantes na literatura de governança, a saber: i) disclosure (DISC); ii) composição e funcionamento do conselho (BOARD); iii) ética e conflitos de interesse (ETHIC); e iv) direito dos acionistas (RIGHT). A primeira dimensão é composta por 6 questões, a segunda por 5, a terceira por 4 e a última por 5. A amostra é composta por 216 empresas. O IGOV e seus subíndices estão padronizados para variar entre 0 e 10. 
Conforme a tabela, a média do IGOV evoluiu cerca de $14 \%$ entre 2005 e 2007. A maior evolução foi a do subíndice DISC, com crescimento de cerca de $27 \%$ no período. Em contrapartida, o subíndice ETHIC caiu aproximadamente 13\%. Por meio um teste $t$ de Student comparando-se a média de 2005 com a de 2007 para todos os índices, concluí-se que o IGOV e DISC tiveram um aumento estatisticamente significativo a $5 \%$ ao longo do período.

Todavia, mesmo com um aumento significativo, observa-se que a pontuação média não chegou à metade da pontuação máxima possível no último ano de análise. Ou seja, a qualidade de governança corporativa das companhias vem aumentando de forma gradual, porém a qualidade geral ainda pode ser considerada insatisfatória. Esta conclusão é semelhante à de Silveira e Barros (2007, p. 17), que analisaram 154 empresas analisadas para o ano de 2002, e à de Leal e Carvalhal-da-Silva (2005, p. 24), que analisaram a evolução da qualidade de governança entre 1998 e 2002 por meio de um índice elaborado pelos autores.

No Gráfico 1 consta a distribuição total do IGOV no período de 2005 a 2007, novamente padronizado em uma faixa de zero a dez pontos.

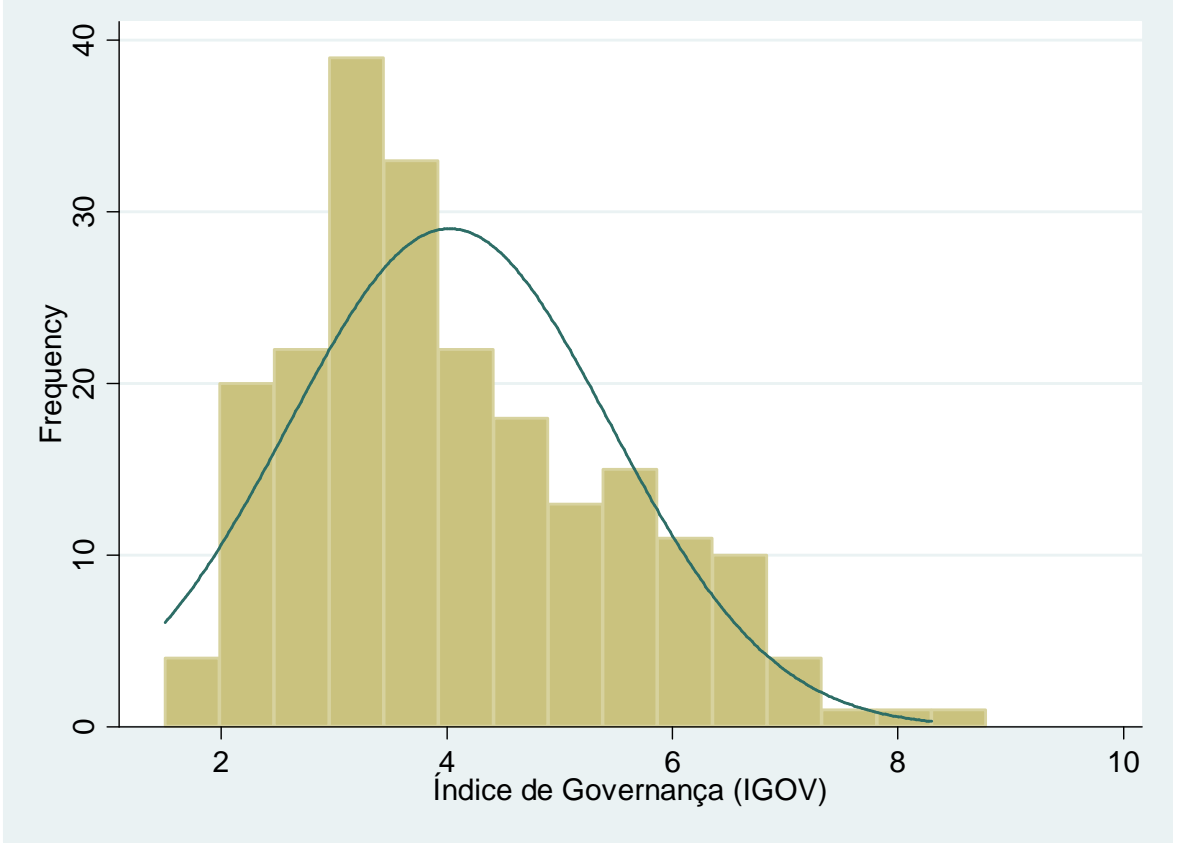

Gráfico 1 - Histograma da distribuição do IGOV entre 2005 e 2007.

O histograma refere-se à distribuição do IGOV no período de 2005 a 2007 . O IGOV é construído com base em um questionário composto por 20 questões, sendo 16 binárias, nas quais uma resposta positiva em relação ao que é tido como uma boa prática de governança corporativa representa um ponto adicional para a firma. Quatro questões apresentam pontuação intermediária (questões 1, 2, 16 e 17): 0; 0,5 e 1 . A pontuação mínima é 0 e a 
máxima 20. A amostra é composta por 216. O IGOV foi padronizado para variar entre 0 e 10.

Observa-se pelo Gráfico 1 que o IGOV é altamente concentrado entre 3 e 4 pontos. Para testar a normalidade do índice, realizaram-se os testes de Jarque-Bera e Shapiro-Wilk. Formalmente, ambos os testes rejeitam a hipótese de normalidade da distribuição dos valores do IGOV.

$\mathrm{Na}$ Tabela 4, são apresentadas as principais estatísticas descritivas das proxies para competição utilizadas na pesquisa.

Tabela 4 - Estatísticas descritivas das proxies de competição

\begin{tabular}{clcccccc}
\hline Ano & Variáveis & Média & Desvio-padrão & $\mathbf{1}^{\circ}$ quartil & Mediana & $\mathbf{3}^{\circ}$ quartil & Amostra \\
\hline \multirow{6}{*}{2005} & HHI_4 & 0.17 & 0.18 & 0.05 & 0.12 & 0.21 & 75 \\
& HHI_3 & 0.10 & 0.16 & 0.02 & 0.05 & 0.10 & 75 \\
& CR4_3 & 0.41 & 0.24 & 0.20 & 0.36 & 0.51 & 75 \\
& NCOMP_4 & 174 & 350 & 28 & 88 & 150 & 75 \\
& NCOMP_3 & 1820 & 3200 & 240 & 633 & 2183 & 75 \\
\hline \multirow{6}{*}{2006} & HHI_4 & 0.19 & 0.20 & 0.05 & 0.13 & 0.25 & 69 \\
& HHI_3 & 0.11 & 0.18 & 0.02 & 0.04 & 0.10 & 69 \\
& CR4_3 & 0.40 & 0.24 & 0.19 & 0.33 & 0.49 & 69 \\
& NCOMP_4 & 130 & 180 & 24 & 82 & 142 & 69 \\
& NCOMP_3 & 1812 & 2846 & 212 & 726 & 2147 & 69 \\
\hline \multirow{6}{*}{2007} & HHI_4 & 0.17 & 0.20 & 0.05 & 0.09 & 0.22 & 72 \\
& HHI_3 & 0.09 & 0.16 & 0.02 & 0.03 & 0.08 & 72 \\
& CR4_3 &. &. &. &. &. & 0 \\
& NCOMP_4 & 140 & 169 & 26 & 95 & 178 & 72 \\
& NCOMP_3 & 2141 & 3233 & 353 & 1100 & 2873 & 72 \\
\hline \multirow{6}{*}{ Total } & HHI_4 & 0.18 & 0.19 & 0.05 & 0.11 & 0.23 & 216 \\
& HHI_3 & 0.10 & 0.17 & 0.02 & 0.04 & 0.09 & 216 \\
& CR4_3 & 0.40 & 0.24 & 0.19 & 0.34 & 0.51 & 144 \\
& NCOMP_4 & 149 & 249 & 26 & 90 & 159 & 216 \\
& NCOMP_3 & 1925 & 3092 & 290 & 836 & 2336 & 216 \\
\hline
\end{tabular}

A tabela contém as estatísticas descritivas das proxies de competição empregadas na pesquisa. O HHI_4 foi calculado pela soma do quadrado da participação de mercado das companhias, considerando como definição de mercado a CNAE a quatro dígitos (classe). O HHI_3 foi calculado pela soma do quadrado da participação de mercado das companhias, considerando como definição de mercado a CNAE a três dígitos (grupo). O C4_3 foi calculado pela soma das quatro maiores participações de mercado, considerando como definição de mercado a CNAE a três dígitos (grupo). NCOMP_4 foi obtida pela soma do número de competidores atuantes no mercado, considerando como definição de mercado a CNAE a quatro dígitos (classe). NCOMP_3 foi obtida pela soma do número de competidores atuantes no mercado, considerando como definição de mercado a CNAE a três dígitos (grupo).

O HHI_4 apresenta maior concentração do que o HHI_3, 0,18 e 0,10, respectivamente. Isso pode ser explicado pela melhor definição de mercado da variável HHI_4. Quanto mais bem especificado o mercado de atuação da firma, menor tende a ser o número de competidores, 
implicando no aumento do HHI. A diferença entre ambos fica mais evidente quando se analisa a mediana e o terceiro quartil da amostra de 216 empresas.

Com relação às demais variáveis de competição, tem-se que a razão de concentração C4_3 está disponível apenas para dois anos do estudo, 2005 e 2006. A mediana da soma dos quatro principais participantes de um mercado é igual a 31\%, sendo que, da amostra, $25 \%$ das empresas atuam em setores nos quais os quatro principais líderes detêm mais de $51 \%$ das vendas. As variáveis NCOMP_3 e NCOMP_4 também apresentaram significativas diferenças, tendo em vista a definição de mercado de cada uma. Quando a definição de mercado relevante da firma é feita por meio da CNAE a três dígitos, há uma média de 1925 concorrentes. Por outro lado, quando a definição de mercado relevante da firma é feita com base na CNAE a quatro dígitos, o número médio de competidores cai para 149.

Quanto às variáveis de desempenho utilizadas no estudo, na Tabela 5 há um resumo estatístico de cada um delas.

Tabela 5 - Estatísticas descritivas das proxies de desempenho

\begin{tabular}{clcccccc}
\hline Ano & Variáveis & Média & Des vio-padrão & $\mathbf{1}^{\circ}$ quartil & Mediana & $\mathbf{3}^{\circ}$ quartil & Amostra \\
\hline \multirow{3}{*}{2005} & EBIT_AT & 0.09 & 0.12 & 0.05 & 0.10 & 0.17 & 75 \\
& EBITDA_AT & 0.13 & 0.12 & 0.09 & 0.14 & 0.20 & 74 \\
& EBITDA_REC & 0.10 & 0.35 & 0.08 & 0.13 & 0.18 & 75 \\
& TOBINSQ & 1.04 & 0.76 & 0.54 & 0.86 & 1.30 & 68 \\
\hline \multirow{5}{*}{2006} & EBIT_AT & 0.08 & 0.10 & 0.03 & 0.08 & 0.15 & 68 \\
& EBITDA_AT & 0.11 & 0.10 & 0.06 & 0.11 & 0.18 & 67 \\
& EBITDA_REC & 0.13 & 0.13 & 0.06 & 0.12 & 0.17 & 68 \\
& TOBINSQ & 1.37 & 1.23 & 0.63 & 1.07 & 1.57 & 62 \\
\hline \multirow{3}{*}{2007} & EBIT_AT & 0.08 & 0.10 & 0.03 & 0.08 & 0.15 & 71 \\
& EBITDA_AT & 0.12 & 0.10 & 0.05 & 0.12 & 0.20 & 71 \\
& EBITDA_REC & 0.13 & 0.18 & 0.06 & 0.13 & 0.19 & 71 \\
& TOBINSQ & 1.69 & 1.21 & 0.86 & 1.34 & 2.05 & 71 \\
\hline \multirow{6}{*}{ Total } & EBIT_AT & 0.09 & 0.10 & 0.03 & 0.08 & 0.16 & 214 \\
& EBITDA_AT & 0.12 & 0.11 & 0.06 & 0.12 & 0.20 & 212 \\
& EBITDA_REC & 0.12 & 0.24 & 0.07 & 0.13 & 0.18 & 214 \\
& TOBINSQ & 1.37 & 1.11 & 0.62 & 1.06 & 1.67 & 201 \\
\hline
\end{tabular}

A tabela contém as estatísticas descritivas das variáveis de desempenho empregadas na pesquisa. O Q de Tobin é dado pela soma do valor de mercado das ações ordinárias (VMAO), valor de mercado das ações preferenciais (VMAP), valor contábil da dívida (VCD). O resultado desta soma é dividido pelo ativo total da companhia (AT). A variável EBIT_AT é calculada pela divisão do lucro operacional próprio pelo ativo total. A variável EBITDA_AT é obtida pela divisão da geração bruta de caixa pelo ativo total EBITDA_AT. EBITDA_REC é obtida pela divisão do lucro antes de juros, imposto de renda, depreciação e amortização pela receita operacional líquida. 
A variável EBIT_AT, que expressa o retorno sobre os ativos, tem média de 9\% e desviopadrão de $10 \%$ no período 2005-2007, o que pode ser considerado relativamente baixo. Além disso, a média e mediana estão bastante próximas, sugerindo uma distribuição simétrica dos retornos. A geração bruta de caixa em relação ao ativo total da companhia, expressa pela variável EBITDA_AT, é de $12 \%$, com média de $11 \%$ e mediana de $20 \%$. A variável EBITDA_REC, que é uma métrica de rentabilidade, apresenta maior variabilidade que as demais. Isso pode ser constatado pelo seu coeficiente de variação de 2,06, aproximadamente. Por fim, o Q de Tobin apresenta média geral de 1,37 e mediana de 1,67, com uma evolução significativa ao longo do tempo, provavelmente refletindo o aumento da valorização das empresas no mercado acionário brasileiro no período.

A Tabela 6 apresenta as estatísticas descritivas para as demais variáveis do estudo.

Tabela 6 - Estatísticas descritivas das demais variáveis de controle

\begin{tabular}{|c|c|c|c|c|c|c|c|}
\hline Ano & Variáveis & Média & Des vio-padrão & $1^{\circ}$ quartil & Mediana & $3^{\circ}$ quartil & Amostra \\
\hline \multirow{8}{*}{2005} & 3VDIR & 0.80 & 0.17 & 0.69 & 0.85 & 0.95 & 75 \\
\hline & CRESC & 0.54 & 1.80 & -0.51 & 0.27 & 1.21 & 75 \\
\hline & LEV & 0.31 & 0.47 & 0.10 & 0.24 & 0.36 & 75 \\
\hline & TANG & 0.34 & 0.18 & 0.17 & 0.35 & 0.48 & 75 \\
\hline & SIZE & 13.26 & 1.87 & 12.23 & 13.01 & 14.22 & 75 \\
\hline & DIVYELD & 0.05 & 0.06 & 0.00 & 0.04 & 0.06 & 75 \\
\hline & AGE & 65 & 26 & 47 & 59 & 85 & 75 \\
\hline & VOTE & 0.51 & 0.19 & 0.35 & 0.43 & 0.59 & 75 \\
\hline \multirow{8}{*}{2006} & 3VDIR & 0.80 & 0.18 & 0.64 & 0.85 & 0.95 & 69 \\
\hline & CRESC & -0.04 & 2.14 & -0.63 & -0.09 & 0.93 & 69 \\
\hline & LEV & 0.25 & 0.27 & 0.11 & 0.20 & 0.34 & 68 \\
\hline & TANG & 0.35 & 0.18 & 0.18 & 0.37 & 0.46 & 69 \\
\hline & SIZE & 13.27 & 2.29 & 12.38 & 13.22 & 14.32 & 69 \\
\hline & DIVYELD & 0.04 & 0.05 & 0.00 & 0.03 & 0.04 & 69 \\
\hline & AGE & 68.29 & 26.30 & 51.00 & 63.00 & 88.00 & 69 \\
\hline & VOTE & 0.53 & 0.22 & 0.35 & 0.43 & 0.61 & 69 \\
\hline \multirow{8}{*}{2007} & 3VDIR & 0.78 & 0.19 & 0.61 & 0.84 & 0.95 & 72 \\
\hline & CRESC & 0.05 & 1.65 & -0.46 & -0.05 & 0.37 & 72 \\
\hline & LEV & 0.29 & 0.45 & 0.12 & 0.217 & 0.33 & 71 \\
\hline & TANG & 0.36 & 0.20 & 0.17 & 0.36 & 0.47 & 72 \\
\hline & SIZE & 13.30 & 2.27 & 12.16 & 13.18 & 14.46 & 72 \\
\hline & DIVYELD & 0.03 & 0.03 & 0.00 & 0.02 & 0.04 & 72 \\
\hline & AGE & 68.38 & 27.21 & 51.50 & 64.50 & 88.00 & 72 \\
\hline & VOTE & 0.55 & 0.24 & 0.34 & 0.44 & 0.68 & 72 \\
\hline \multirow{8}{*}{ Total } & 3VDIR & 0.79 & 0.18 & 0.64 & 0.84 & 0.95 & 216 \\
\hline & CRESC & 0.19 & 1.88 & -0.55 & -0.01 & 0.91 & 216 \\
\hline & LEV & 0.28 & 0.41 & 0.11 & 0.22 & 0.34 & 214 \\
\hline & TANG & 0.35 & 0.19 & 0.17 & 0.36 & 0.48 & 216 \\
\hline & SIZE & 13.28 & 2.13 & 12.23 & 13.09 & 14.34 & 216 \\
\hline & DIVYELD & 0.04 & 0.05 & 0.00 & 0.03 & 0.05 & 216 \\
\hline & AGE & 67.08 & 26.32 & 50.00 & 63.00 & 87.00 & 216 \\
\hline & VOTE & 0.53 & 0.22 & 0.35 & 0.43 & 0.62 & 216 \\
\hline
\end{tabular}


A tabela contém as estatísticas descritivas de algumas variáveis de controle utilizadas na pesquisa. 3VDIR é calculada pela soma do percentual das ações ordinárias detidas pelos três maiores acionistas. CRESC é o percentual acumulado das vendas dos últimos três exercícios. LEV é dada pela divisão da dívida total pelo ativo total. TANG é dado pelo ativo imobilizado bruto sobre a receita operacional líquida, SIZE é o logaritmo natural da receita líquida operacional. DIVYELD é calculada pela soma dos dividendos e demais rendimentos da ação pagos por ação sobre o preço da ação. AGE é mensurada pelo número de anos da fundação da companhia. VOTE é o percentual de ações ordinárias em relação ao total de ações, mensurado pela divisão do número de ações ordinárias pelo número total de ações.

A variável 3VDIR representa o percentual de ações com direito a voto detido pelos três maiores acionistas da companhia. Em média, os três maiores acionistas possuem $79 \%$ das ações com direito a voto. Esse resultado é bastante coerente com as estatísticas descritivas do trabalho de Leal e Carvalhal-da-Silva (2005, p. 63), no qual os autores identificaram que os três maiores acionistas possuíam $83 \%$ das ações com direito a votos. Além disso, o desviopadrão em ambas as pesquisas é igual, de 18\%. A pesquisa também apresenta resultados coerentes com o trabalho de Silveira et al.(2007, p. 35). Em termos de variabilidade, a variável CRESC é a que se destaca, pois possui o coeficiente de variação de 9,85, o mais elevado entre todas as variáveis de controle da pesquisa.

Apesar de a PIA-Empresa abranger apenas as indústrias extrativas e de transformação, vê-se que a abrangência das empresas da amostra quando inseridas na classificação do sistema de informações Economática é maior, conforme a Tabela 7.

Tabela 7 - Distribuição setorial do Economática

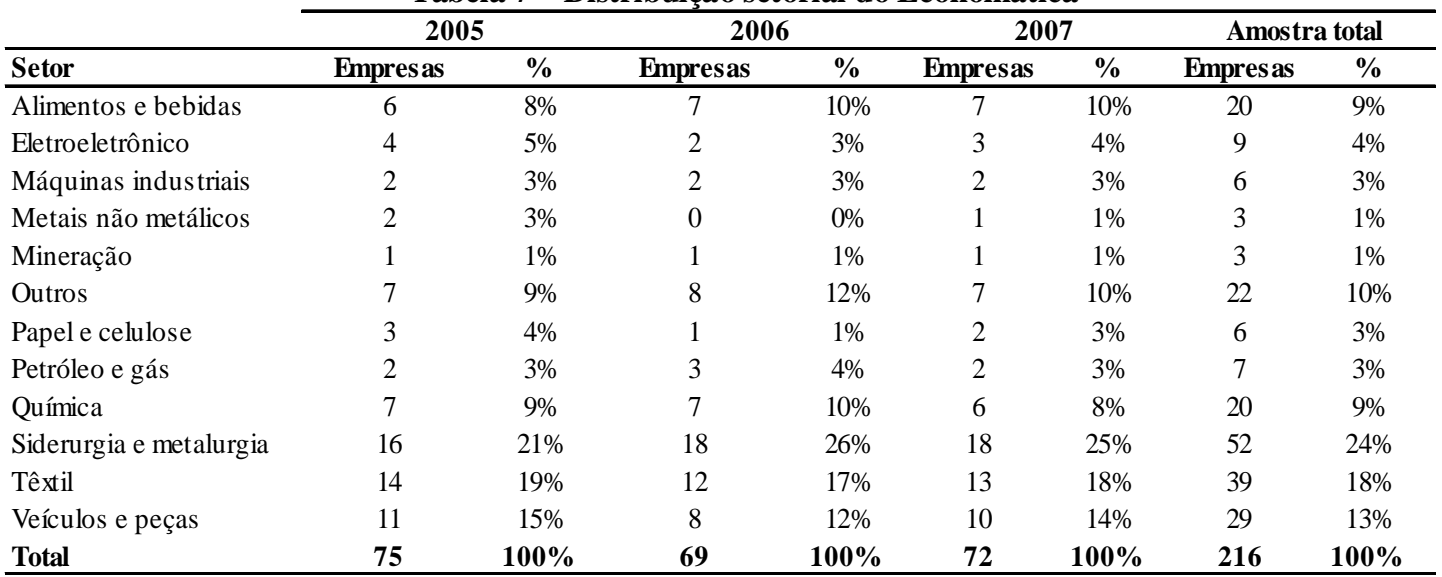

A tabela contém a distribuição dos setores, conforme classificação do sistema de informações Economática.

No geral, os setores de Siderurgia e Metalurgia, Têxtil e Veículos e Peças são os que contribuem com o maior número de companhias para a pesquisa, com $24 \%$, $18 \%$ e $13 \%$, 
respectivamente. Esses percentuais são coerentes com o tipo de amostra utilizada na pesquisa, pois esses são setores pertencentes à indústria de extração e transformação. A classificação do sistema Economática é bastante genérica, porém será utilizada como forma de controlar os efeitos do setor de atuação da companhia.

A fim de estabelecer uma comparação entre a classificação setorial do Economática e a classificação setorial por meio da CNAE, na Tabela 8 as companhias estão agrupadas pelas suas respectivas atividades econômicas.

Tabela 8 - Distribuição setorial da CNAE

\begin{tabular}{|c|c|c|c|c|c|c|c|c|c|}
\hline \multirow{2}{*}{\begin{tabular}{|l} 
GRUPO \\
CNAE
\end{tabular}} & \multirow[b]{2}{*}{ DES CRIÇÃO } & \multicolumn{2}{|c|}{2005} & \multicolumn{2}{|c|}{2006} & \multicolumn{2}{|c|}{2007} & \multicolumn{2}{|c|}{ Total } \\
\hline & & Empresas & $\%$ & Empresas & $\%$ & Empresas & $\%$ & Empresas & $\%$ \\
\hline 131 & Extração de Minério de Ferro & 1 & $1 \%$ & 1 & $1 \%$ & 1 & $1 \%$ & 3 & $1 \%$ \\
\hline 153 & Produção de Óleos e Gorduras Vegetais e Animais & 1 & $1 \%$ & 1 & $1 \%$ & & $0 \%$ & 2 & $1 \%$ \\
\hline 154 & Laticínios & 2 & $3 \%$ & 2 & $3 \%$ & 2 & $3 \%$ & 6 & $3 \%$ \\
\hline 157 & Torrefação e Moagem de Café & 1 & $1 \%$ & 1 & $1 \%$ & 1 & $1 \%$ & 3 & $1 \%$ \\
\hline 158 & Fabricação de Outros Produtos Alimentícios & & $0 \%$ & & $0 \%$ & 1 & $1 \%$ & 1 & $0 \%$ \\
\hline 160 & Fabricação de Produtos do Fumo & 1 & $1 \%$ & 1 & $1 \%$ & 1 & $1 \%$ & 3 & $1 \%$ \\
\hline 172 & Fiação & 3 & $4 \%$ & 2 & $3 \%$ & 2 & $3 \%$ & 7 & $3 \%$ \\
\hline 173 & Tecelagem & 4 & $5 \%$ & 3 & $4 \%$ & 3 & $4 \%$ & 10 & $5 \%$ \\
\hline 176 & Fabricação de Artefatos Têxteis & 4 & $5 \%$ & 4 & $6 \%$ & 5 & $7 \%$ & 13 & $6 \%$ \\
\hline 177 & Fabricação de Tecidos e Artigos de Malha & 1 & $1 \%$ & 1 & $1 \%$ & 1 & $1 \%$ & 3 & $1 \%$ \\
\hline 181 & Confecção de Artigos do Vestuário & 2 & $3 \%$ & 1 & $1 \%$ & 1 & $1 \%$ & 4 & $2 \%$ \\
\hline 232 & Fabricação de Produtos Derivados de Petróleo & 2 & $3 \%$ & 3 & $4 \%$ & 2 & $3 \%$ & 7 & $3 \%$ \\
\hline 241 & Fabricação de Produtos Químicos Inorgânicos & 2 & $3 \%$ & 2 & $3 \%$ & 1 & $1 \%$ & 5 & $2 \%$ \\
\hline 242 & Fabricação de Produtos Químicos Orgânicos & 3 & $4 \%$ & 3 & $4 \%$ & 3 & $4 \%$ & 9 & $4 \%$ \\
\hline 243 & Fabricação de Resinas e Elastomeros & 1 & $1 \%$ & 1 & $1 \%$ & 1 & $1 \%$ & 3 & $1 \%$ \\
\hline 245 & Fabricação de Produtos Farmacêuticos & 1 & $1 \%$ & 1 & $1 \%$ & & $0 \%$ & 2 & $1 \%$ \\
\hline 247 & Fabricação de Sabores, Detergentes e Produtos de Limpeza & 1 & $1 \%$ & 1 & $1 \%$ & 1 & $1 \%$ & 3 & $1 \%$ \\
\hline 252 & Fabricação de Produtos de Material Plástico & 1 & $1 \%$ & 1 & $1 \%$ & 1 & $1 \%$ & 3 & $1 \%$ \\
\hline 261 & Fabricação de Vidro e de Produtos do Vidro & 1 & $1 \%$ & & $0 \%$ & & $0 \%$ & 1 & $0 \%$ \\
\hline 264 & Fabricação de Produtos Cerâmicos & 1 & $1 \%$ & & $0 \%$ & 1 & $1 \%$ & 2 & $1 \%$ \\
\hline 271 & Produção de Ferro-Gusa e de Ferroligas & 1 & $1 \%$ & 1 & $1 \%$ & 1 & $1 \%$ & 3 & $1 \%$ \\
\hline 272 & Siderurgia & 4 & $5 \%$ & 4 & $6 \%$ & 4 & $6 \%$ & 12 & $6 \%$ \\
\hline 273 & Fabricação de Tubos & 1 & $1 \%$ & 1 & $1 \%$ & 1 & $1 \%$ & 3 & $1 \%$ \\
\hline 284 & Fabricação de Artigos de Cutelaria, de Serralheria e Ferramentas Manuais & 1 & $1 \%$ & 1 & $1 \%$ & 2 & $3 \%$ & 4 & $2 \%$ \\
\hline 289 & Fabricação de Produtos Diversos de Metal & 4 & $5 \%$ & 5 & $7 \%$ & 4 & $6 \%$ & 13 & $6 \%$ \\
\hline 291 & Fabricação de Motores, Bombas Compressores e Equipamentos de Transmissão & 1 & $1 \%$ & & $0 \%$ & 1 & $1 \%$ & 2 & $1 \%$ \\
\hline 292 & Fabricação de Máquinas e Equipamentos de Uso Geral & 1 & $1 \%$ & 1 & $1 \%$ & 1 & $1 \%$ & 3 & $1 \%$ \\
\hline 293 & Fabricação de Tratores e de Máquinas de Equipamentos para a Agricultura & 1 & $1 \%$ & 1 & $1 \%$ & 1 & $1 \%$ & 3 & $1 \%$ \\
\hline 294 & Fabricação de Máquinas-Ferramentas & 1 & $1 \%$ & 1 & $1 \%$ & 1 & $1 \%$ & 3 & $1 \%$ \\
\hline 297 & Fabricação de Armas, Municações e Equipamentos Militares & 1 & $1 \%$ & 2 & $3 \%$ & 1 & $1 \%$ & 4 & $2 \%$ \\
\hline 302 & Fabricação de Máquinas e Equipamentos de Sistemas Eletrônicos para PD & 1 & $1 \%$ & 1 & $1 \%$ & 1 & $1 \%$ & 3 & $1 \%$ \\
\hline 311 & Fabricação de Geradores, Transformadores e Motores Elétricos & 1 & $1 \%$ & 1 & $1 \%$ & 1 & $1 \%$ & 3 & $1 \%$ \\
\hline 312 & Fabricação de para Distribuição e Controle de Energia Elétrica & 1 & $1 \%$ & & $0 \%$ & 1 & $1 \%$ & 2 & $1 \%$ \\
\hline 323 & Fabricação de Aparelhos Receptores de Rádio e Televisão e Reprodução & 1 & $1 \%$ & & $0 \%$ & & $0 \%$ & 1 & $0 \%$ \\
\hline 343 & Fabricação de Cabines, Carrocerias e Reboques & 3 & $4 \%$ & 2 & $3 \%$ & 3 & $4 \%$ & 8 & $4 \%$ \\
\hline 344 & Fabricação de Peças e Acessórios para Veículos Automotores & 5 & $7 \%$ & 3 & $4 \%$ & 4 & $6 \%$ & 12 & $6 \%$ \\
\hline 352 & Construção, Montagem e Reparação de Veículos Ferroviários & & $0 \%$ & 1 & $1 \%$ & 1 & $1 \%$ & 2 & $1 \%$ \\
\hline 353 & Construção, Montageme Reparação de Aeronaves & 1 & $1 \%$ & 1 & $1 \%$ & 1 & $1 \%$ & 3 & $1 \%$ \\
\hline 359 & Fabricação de Outros Equipamentos de Transporte & 1 & $1 \%$ & & $0 \%$ & & $0 \%$ & 1 & $0 \%$ \\
\hline \multirow[t]{2}{*}{369} & Fabricação de Produtos Diversos & 2 & $3 \%$ & 3 & $4 \%$ & 3 & $4 \%$ & 8 & $4 \%$ \\
\hline & Total geral & 75 & $100 \%$ & 69 & $100 \%$ & 72 & $100 \%$ & 216 & $100 \%$ \\
\hline
\end{tabular}

A tabela contém a distribuição das empresas de acordo com a CNAE ao nível do grupo. 
Não obstante o fato de na pesquisa a classificação setorial do Economática ser utilizada para controlar efeitos específicos da indústria, pode ser que esse procedimento não seja eficiente. Como citado na subseção 3.2.2.2, Clarke (1989), Kahle e Walking (1996) e Bhoraj et al. (2003) discorrem justamente sobre o impacto das classificações setoriais utilizadas em pesquisas empíricas na área de finanças sobre os resultados dos testes estatísticos. A utilização de classificações setoriais genéricas acaba por unir companhias com atividades totalmente diferentes em um mesmo setor. Logo, o real efeito do setor pode não ser considerado, de fato, nas pesquisas.

Na Tabela 9, constam quem são os controladores das companhias utilizadas na amostra do estudo.

Tabela 9 - Distribuição do tipo de acionista controlador

\begin{tabular}{lcccccccc} 
& \multicolumn{2}{c}{$\mathbf{2 0 0 5}$} & \multicolumn{2}{c}{$\mathbf{2 0 0 6}$} & \multicolumn{2}{c}{$\mathbf{2 0 0 7}$} & \multicolumn{2}{c}{ Amostra total } \\
\cline { 2 - 9 } Controle & Empresas & \% & Empresas & \% & Empresas & \% & Empresas & \% \\
\hline Familiar & 50 & $67 \%$ & 44 & $64 \%$ & 52 & $72 \%$ & 146 & $68 \%$ \\
Estatal & 1 & $1 \%$ & 1 & $1 \%$ & 1 & $1 \%$ & 3 & $1 \%$ \\
Compartilhado & 16 & $21 \%$ & 17 & $25 \%$ & 13 & $18 \%$ & 46 & $21 \%$ \\
Estrangeiro & 6 & $8 \%$ & 6 & $9 \%$ & 4 & $6 \%$ & 16 & $7 \%$ \\
Disperso & 2 & $3 \%$ & 1 & $1 \%$ & 2 & $3 \%$ & 5 & $2 \%$ \\
Total & $\mathbf{7 5}$ & $\mathbf{1 0 0 \%}$ & $\mathbf{6 9}$ & $\mathbf{1 0 0 \%}$ & $\mathbf{7 2}$ & $\mathbf{1 0 0 \%}$ & $\mathbf{2 1 6}$ & $\mathbf{1 0 0 \%}$ \\
\hline
\end{tabular}

A tabela contém a distribuição dos acionistas controladores das empresas da amostra. Divisão efetuada em cinco categorias: Familiar (IDENT_1), Estatal (IDENT_2), Compartilhado (IDENT_3), Estrangeiro (IDENT_4) e Disperso (IDENT_5).

O controle exercido por uma família ou grupo familiar é o mais comum, tendo, em relação a amostra, o controle de $68 \%$ das companhias. Em seguida, segue-se o controle exercido de forma compartilhada, representando $27 \% \mathrm{~d}$ as companhias da amostra. A constatação de que a controle familiar é o predominante na amostra do estudo está em linha com o trabalho de Silveira et al. (2007, p. 35), que estudaram o mercado brasileiro no período de 1998 a 2004.

Por fim, a Tabela 10 apresenta o percentual de companhias emissoras de ADR níveis II e III, bem como as companhias listadas nos segmentos diferenciados de governança corporativa, especificamente o Nível II e o Novo Mercado. 
Tabela 10 - Empresas emissoras de ADRs e/ou listadas nos segmentos diferenciados de governança

\begin{tabular}{lcccccccc} 
& \multicolumn{2}{c}{$\mathbf{2 0 0 5}$} & \multicolumn{2}{c}{$\mathbf{2 0 0 6}$} & \multicolumn{2}{c}{$\mathbf{2 0 0 7}$} & \multicolumn{2}{c}{ Amos tra total } \\
\hline Listagem & Empresas & \% & Empresas & \% & Empresas & \% & Empresas & \% \\
\hline ADR níveis II ou III & 7 & $9 \%$ & 8 & $12 \%$ & 8 & $11 \%$ & 23 & $11 \%$ \\
Nível II e Novo Mercado & 7 & $9 \%$ & 8 & $12 \%$ & 9 & $13 \%$ & 24 & $11 \%$ \\
\hline A & 7 & $8 \%$
\end{tabular}

A tabela contém a distribuição das empresas emissoras de American Depositary Receipts níveis II e III
(ADR23) e/ou empresas listadas nos segmentos diferenciados em termos de governança corporativa, especificamente o Nível II e o Novo Mercado (N2NM).

Após a apresentação de estatísticas descritivas consideradas relevantes para a compreensão do conjunto de dados da pesquisa, as duas próximas seções discutem os resultados dos problemas investigados na pesquisa.

\subsection{Efeitos da competição sobre a qualidade de governança corporativa}

A investigação da presença de relação linear entre variáveis é um interessante ponto de partida em estudos empíricos. Parte da estrutura da pesquisa visa a investigar se a competição no mercado de produtos possui alguma relação com a qualidade de governança corporativa. Assim, o estudo exploratório por meio de simples gráficos, sem o intuito de inferir sobre relações de causalidade, pode contribuir no entendimento do relacionamento entre as variáveis. Guadalupe e Pérez-Gonzalez (2006, p. 38) também utilizam gráficos para apresentar uma simples relação entre competição e os benefícios privados do controle. Na pesquisa, os autores, como já apresentado na revisão da literatura, concluem haver relação negativa entre grau de competição e prêmio pelas ações com direito a voto, cujo mote pode ser aproveitado em pesquisas no mercado brasileiro. Neste sentido, o Gráfico 2 apresenta a relação entre o IGOV e o HHI_4. 


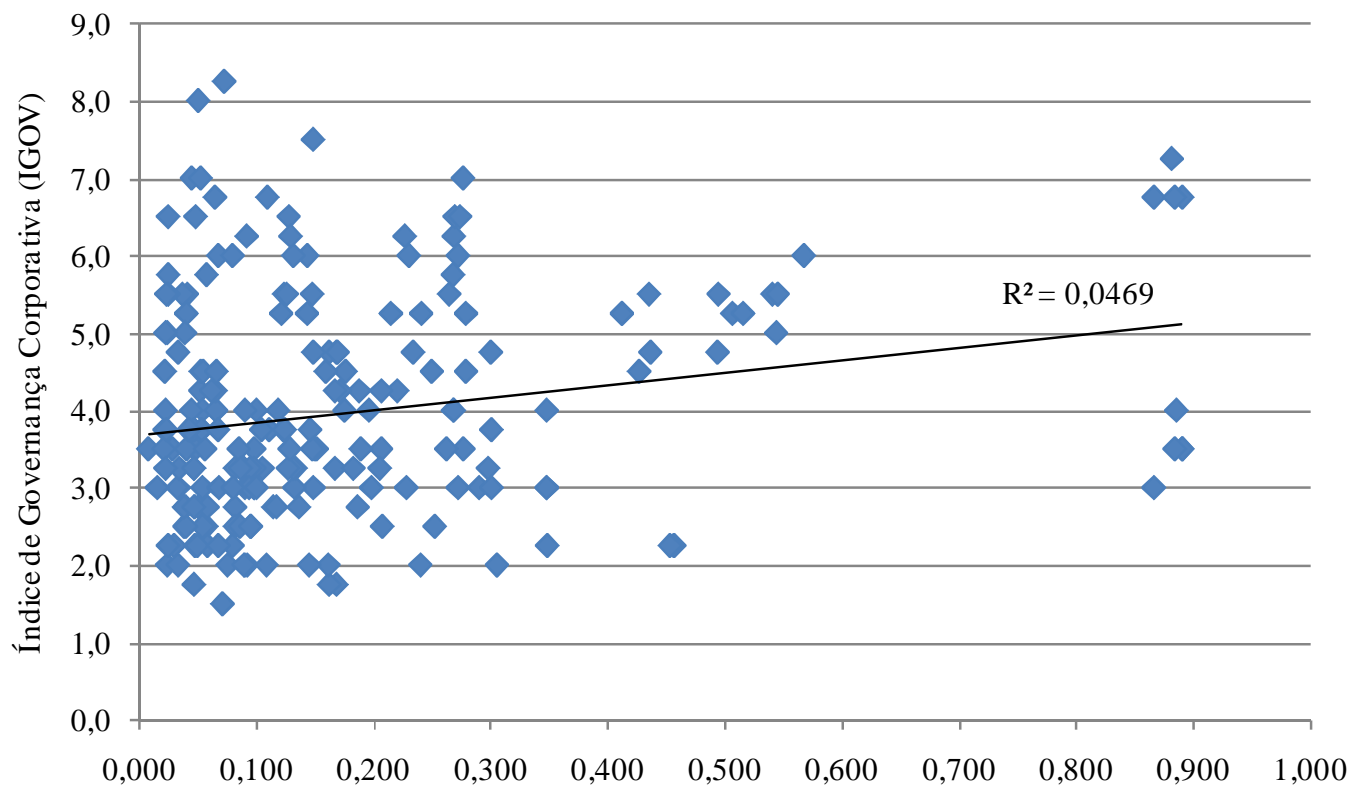

Índice de Herfindahl-Hirschmann a quatro dígitos (HHI_4)

Gráfico 2 - Relação entre IGOV e HHI_4 entre 2005 e 2007.

O gráfico refere-se à variação do IGOV elaborado pelo IBGC em função do HHI_4. O IGOV é construído com base em um questionário composto por 20 questões, sendo 16 binárias, nas quais uma resposta positiva em relação ao que é tido como uma boa prática de governança corporativa representa um ponto adicional para a firma. Quatro questões apresentam pontuação intermediária (questões 1,2,16 e 17): 0; 0,5 e 1. A pontuação mínima é 0 e a máxima 20. A amostra é composta por 216. O IGOV foi padronizado para variar entre 0 e 10. O HHI_4 foi calculado pela soma do quadrado da participação de mercado das companhias, considerando como definição de mercado a CNAE a quatro dígitos (classe).

O período do Gráfico 2 é de 2005 a 2007, base para as análises da presente pesquisa. O R ${ }^{2}$ de 0,0469 é resultado de uma regressão simples entre IGOV (dependente) e HHI_4 (independente), e o coeficiente da variável competição apresentou significância estatística.

Com intuito de verificar a persistência do resultado, elaborou-se análise semelhante para o período de 2000 a $2004^{54}$, utilizando-se o IGOV desenvolvido por Leal e Carvalhal-da-Silva (2005)

\footnotetext{
${ }^{54}$ A variável HHI_4 só está disponível de 2000 em diante.
} 


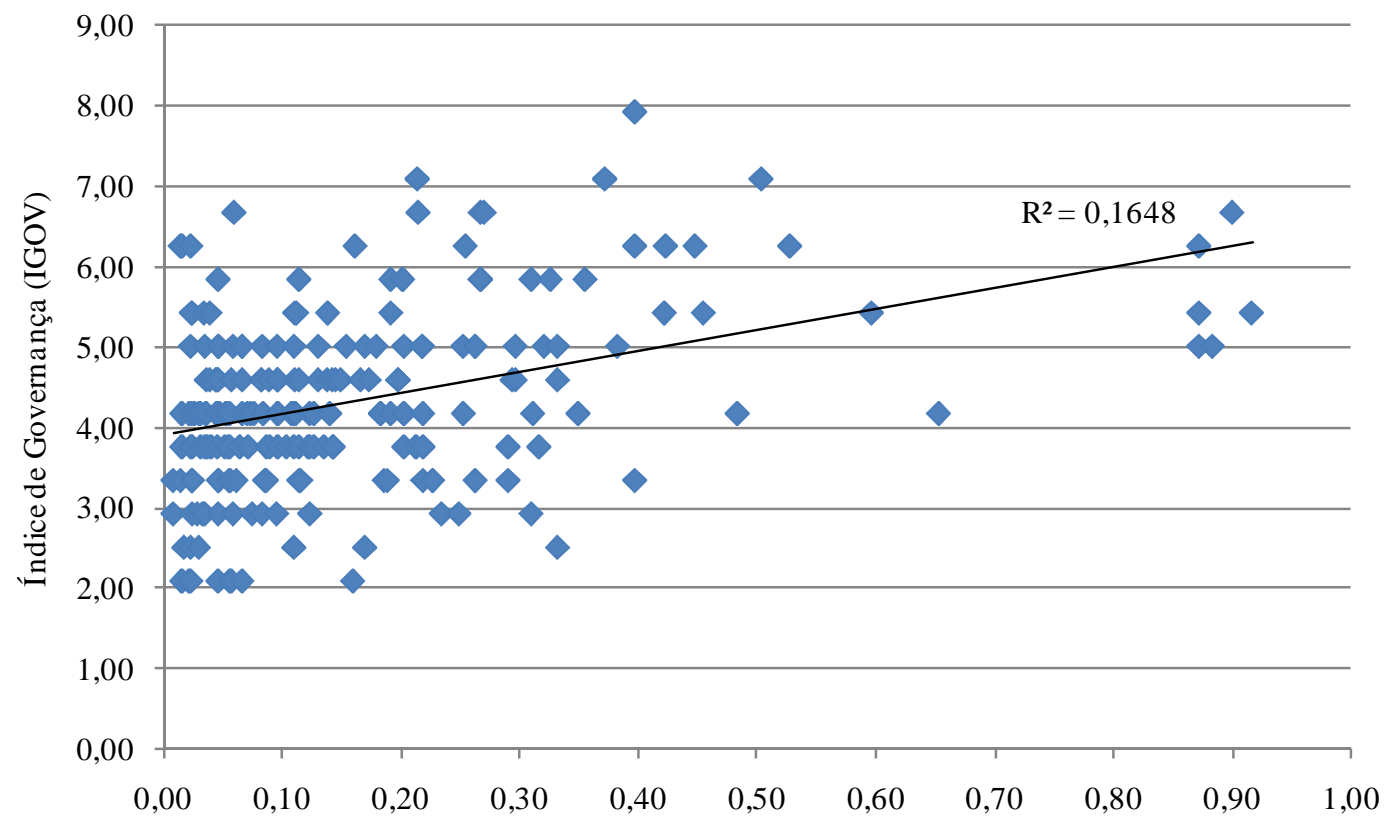

Índice de Herfindahl-Hirschmann a quatro dígitos(HHI_4)

Gráfico 3 - Relação entre IGOV e HHI_4 entre 2000 e 2004. $\mathrm{O}$ gráfico refere-se à variação do IGOV calculado pelos pesquisadores Leal e Carvalhal-da-Silva (2005) em função do HHI_4. O IGOV desenvolvido pelos pesquisadores é construído com base em um questionário composto por 24 questões binárias, nas quais uma resposta positiva em relação ao que é tido como uma boa prática de governança corporativa representa um ponto adicional para a firma. A pontuação mínima é 0 e a máxima 24. A amostra é composta por 304. O IGOV foi padronizado para variar entre 0 e 10. . O HHI_4 foi calculado pela soma do quadrado da participação de mercado das companhias, considerando como definição de mercado a CNAE a quatro dígitos (classe).

Uma possível interpretação do gráfico é que, quanto maior a concentração do mercado no qual a firma atua, maior a qualidade de governança corporativa. $\mathrm{O} \mathrm{R}^{2}$ de 0,1648 é resultado de uma regressão simples entre IGOV (dependente) e HHI_4 (independente) e o coeficiente da variável de competição apresentou significância estatística. Em comparação com o período de 2005 a 2007, o $\mathrm{R}^{2}$ foi maior. Todavia, essa é ainda uma análise preliminar e o resultado deve ser analisado com cautela, visto que outras variáveis impactam a qualidade de governança corporativa e não estão presentes na regressão.

Ambos os resultados sugerem haver relação positiva entre qualidade de governança e grau de concentração no mercado de atuação da firma. Uma hipótese inicial extraída de Allen e Gale 
(1999) é que uma maior competição acaba por não requerer tanta necessidade de mecanismos de governança. Logo, esse resultado preliminar está em linha com o trabalho de Allen e Gale (1999) e com o estudo de Chou et al. (2008).

De forma a expandir as análises apresentadas nos gráficos, construiu-se uma matriz de correlações para os anos de 2005 a 2007, compreendendo todas as proxies de competição utilizadas na pesquisa e o índice de governança corporativa, bem como cada um de seus subíndices. Na Tabela 11, consta a matriz de correlações:

Tabela 11 -Matriz de correlação entre proxies de competição e governança corporativa

\begin{tabular}{|c|c|c|c|c|c|c|c|c|c|c|}
\hline & IGOV & DISC & BOARD & ETHIC & RIGHTS & HHI_4 & HHI_3 & CR4_3 & NCOMP_4 & NCOMP_3 \\
\hline IGOV & 1 & & & & & & & & & \\
\hline \multirow[t]{2}{*}{ DISC } & $0.8439 * * *$ & 1 & & & & & & & & \\
\hline & 0.0000 & & & & & & & & & \\
\hline \multirow[t]{2}{*}{ BOARD } & $0.6605 * * *$ & $0.4377 * * *$ & 1 & & & & & & & \\
\hline & 0.0000 & 0.0000 & & & & & & & & \\
\hline \multirow{2}{*}{ ETHIC } & $0.3306 * * *$ & -0.0075 & 0.0104 & 1 & & & & & & \\
\hline & 0.0000 & 0.9123 & 0.8792 & & & & & & & \\
\hline \multirow[t]{2}{*}{ RIGHTS } & $0.4712 * * *$ & $0.2137 * * *$ & -0.0298 & $0.2495^{*}$ & 1 & & & & & \\
\hline & 0.0000 & 0.0016 & 0.6632 & 0.0002 & & & & & & \\
\hline \multirow[t]{2}{*}{ HHI_4 } & $0.2163 * * *$ & $0.2175^{* * *}$ & $0.1562 *$ & 0.0754 & 0.0066 & 1 & & & & \\
\hline & 0.0014 & 0.0013 & 0.0216 & 0.2702 & 0.9235 & & & & & \\
\hline \multirow[t]{2}{*}{ HHI_3 } & $0.1826 * * *$ & $0.1601 * *$ & $0.1832 * * *$ & 0.0407 & 0.0051 & $0.8508^{*}$ & 1 & & & \\
\hline & 0.0071 & 0.0185 & 0.0069 & 0.5518 & 0.9402 & 0.0000 & & & & \\
\hline \multirow[t]{2}{*}{ C4_3 } & $0.2279 * * *$ & $0.1735^{* *}$ & $0.2148 * * *$ & $0.1497 *$ & -0.081 & $0.7198^{* * *}$ & $0.8214 * * *$ & 1 & & \\
\hline & 0.006 & 0.0376 & 0.0097 & 0.0732 & 0.3347 & 0.0000 & 0.0000 & & & \\
\hline \multirow[t]{2}{*}{ NCOMP_4 } & -0.0334 & -0.0322 & -0.0186 & -0.0476 & 0.0244 & $-0.3476 * * *$ & $-0.2374 * * *$ & $-0.3722 * * *$ & 1 & \\
\hline & 0.6255 & 0.6376 & 0.7854 & 0.4869 & 0.7215 & 0.0000 & 0.0004 & 0.0000 & & \\
\hline \multirow[t]{2}{*}{ NCOMP_3 } & 0.0012 & 0.0039 & -0.117 & 0.0105 & $0.1485 * *$ & $-0.3186 * * *$ & $-0.2774 * * *$ & $-0.4800 * * *$ & $0.7368^{* * *}$ & 1 \\
\hline & 0.986 & 0.9548 & 0.0864 & 0.8782 & 0.0291 & 0.0000 & 0.0000 & 0.0000 & 0.0000 & \\
\hline
\end{tabular}

Matriz de correlações de Pearson entre a variável de qualidade de governança corporativa, IGOV, e seus subíndices, DISC, BOARD, ETHIC e RIGHTS, mensurados conforme a seção 3.2.1 e as variáveis de competição no mercado de produtos, HHI_4, HHI_3, C4_3, NCOMP_4, NCOMP_3, mensuradas conforme a seção 3.2.2, para os anos de 2005 a 2007.***,** e * denotam a significância estatística das estimativas nos níveis de $1 \%, 5 \%$ e $10 \%$, respectivamente.

A matriz de correlações acima apresenta alguns resultados importantes para os objetivos da pesquisa. As variáveis HHI_4, HHI_3 e C4_3 apresentam correlações positivas e estatisticamente significativas com a variável IGOV. Esse resultado indica que, assumindo uma relação de dependência de governança em relação à competição, quanto maior a concentração de um mercado, maior a qualidade de governança corporativa. Esse resultado é semelhante aos obtidos por meio dos Gráficos 2 e 3, todavia expandido para um maior número de variáveis de competição no mercado de produtos. As variáveis NCOMP_4 e NCOMP_3 apresentam resultados distintos. No primeiro caso, a variável apresenta relação negativa com a qualidade de governança corporativa. Uma potencial explicação é que quanto maior o número de competidores (ou quanto maior a competição) menor a qualidade de 
governança. Qualitativamente, esse resultado está em linha com os resultados apresentados pelas outras variáveis de competição. Contudo, não é estatisticamente significativo. A variável NCOMP_3 apresentou resultados inversos aos das demais variáveis de competição, porém também não estatisticamente significativos.

Quanto aos subíndices, o HHI_4 apresentou relação positiva e estatisticamente significativa com DISC e BOARD. A variável HHI_3 se comportou de forma equivalente. A variável C4_3 apresentou relação positiva e estatisticamente significativa com as variáveis DISC, BOARD e ETHIC. A variável de competição NCOMP_4 não apresentou relação estatisticamente significativa com nenhuma das cinco variáveis de governança. A variável NCOMP_3 correlacionou-se positiva e significantemente com o subíndice RIGHTS. Esse resultado indica que quanto maior o número de competidores em determinado setor, maior a proteção concedida aos acionistas.

Como era de se supor sobre a correlação entre os índices de competição utilizados na pesquisa, a matriz mostra que as variáveis HHI_3 e C4_3 apresentam correlação e positiva e estatisticamente significativa com a variável HHI_4. Por outro lado, as variáveis NCOMP_4 e NCOMP_3 apresentaram se relacionam de forma negativa e estatisticamente significante com a variável HHI_4. Resultados esses dentro do esperado.

Em síntese, os resultados da matriz de correlação sugerem que em setores nos quais há maior nível de concentração, a qualidade de governança corporativa é também maior. Ressalta-se que não é possível estabelecer causalidade estrita entre as variáveis, todavia partindo-se das evidências empíricas e teóricas de que competição afeta a estrutura de governança corporativa, esse seria um raciocínio possível e que poderia ensejar o desenvolvimento de estudos empíricos. O último resultado, entre NCOMP_3 e RIGHTS, por exemplo, possui estreita relação com os motes dos artigos de Kadyrzhanova e Rhodes-Kropf (2007), bem como com o de Cremers et al. (2008).

Aqui cabe fazer uma consideração. Na subseção 3.7.2 foi apresentada uma limitação em estudos empíricos advinda da omissão de variáveis. Em análises de correlação este problema está presente. Por exemplo, as empresas com maior poder mercado (em setores com maior concentração) tendem a ser maiores. $\mathrm{O}$ índice de governança também tende a privilegiar 
empresas maiores, já que muitas questões versão sobre qualidade de website de RI, por exemplo. Logo, a maior qualidade da governança corporativa pode ter uma relação mais próxima com o tamanho que, por sua vez, tende a ser correlacionado positivamente com a concentração de mercado. Portanto, os resultados da matriz de correlações são apenas preliminares.

Nos estudos de Chou et al. (2008), Karuna (2008) e Giroud e Mueller (2008), de forma exploratória, são utilizados testes de diferenças de médias entre companhias em setores menos competitivos com companhias pertencentes a setores mais competitivos. A idéia dos testes é identificar potenciais diferenças de comportamento nas variáveis de interesse quando as companhias são separadas por meio do grau de competição de seu setor.

Na pesquisa, a variável de interesse é o IGOV e seus subíndices. Para classificar os setores em competitivos e não competitivos, foi utilizada a distribuição de cada ano das variáveis de competição. Por meio da distribuição, os setores foram separados pela mediana, tercil e quartis. No caso das variáveis HHI_4, HHI_3, C4_3, um setor que apresentasse valores correspondentes à mediana inferior, primeiro tercil ou primeiro quartil, foi considerado como estando exposto à alta competição. Por outro lado, se o setor fosse enquadrado na mediana superior, último tercil ou último quartil, seria classificado como exposto à baixa competição. Quanto às variáveis NCOMP_4 e NCOMP_3, o raciocínio é justamente o oposto.

Na Tabela 12, são apresentados os valores utilizados para proceder-se com as separações.

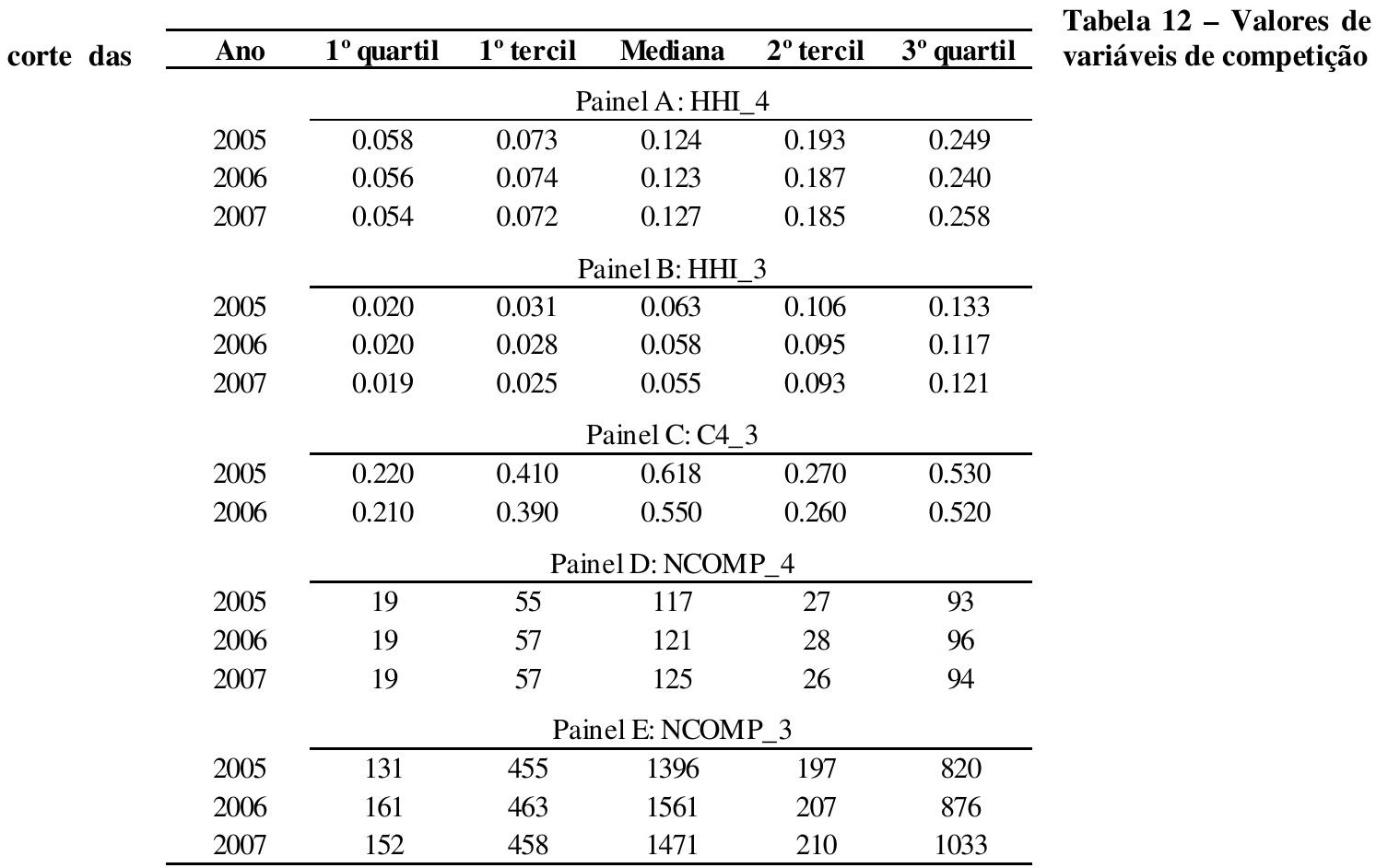


Além da separação ora efetuada, também foi utilizada uma forma arbitrária de classificação dos setores em competitivos e não competitivos. Como explicado na seção 3.5, o guia de análise de atos de concentração horizontais norte-americano divide o HHI em três regiões: i) abaixo de 1000, o mercado é pouco concentrado; ii) entre 1000 e 1800, a concentração é considerada moderada; e iii) acima de 1800, o mercado é considerado altamente concentrado. Assim, conforme o HHI de cada setor, houve a classificação em uma das categorias apresentadas.

Para avaliar a diferença entre médias, utilizou-se o teste paramétrico t de Student para amostrar independentes. $\mathrm{O}$ teste de Levene foi empregado para verificar a adequação das amostras ao pressuposto de homogeneidade da variância. Nos casos em que o pressuposto foi violado, reportou-se o resultado do teste já robusto a não homogeneidade da variância.

Na Tabela 13 estão reportados os testes, divididos em cinco painéis, um para o IGOV e os demais para cada um dos subíndices. 
Tabela 13 - Testes de diferenças de médias

\begin{tabular}{|c|c|c|c|c|c|c|c|c|c|c|c|c|}
\hline \multirow[b]{2}{*}{ Medida } & \multicolumn{3}{|c|}{ Critério: Mediana } & \multicolumn{3}{|c|}{ Critério: Tercis } & \multicolumn{3}{|c|}{ Critério: Quartis } & \multicolumn{3}{|c|}{ Critério: DOJ } \\
\hline & Alta & Baixa & Valor $\mathrm{p}$ & Alta & Baixa & Valor $\mathrm{p}$ & Alta & Baixa & Valor $\mathrm{p}$ & Alta & Baixa & Valor $\mathrm{p}$ \\
\hline & \multicolumn{12}{|c|}{ Painel A: Índice de Governança Corporativa (IGOV) total } \\
\hline HHI_4 & 3.75 & 4.31 & $0,004 * * *$ & 3.95 & 4.42 & $0,055^{*}$ & 3.90 & 4.51 & $0,028 * *$ & 3.73 & 4.37 & $0,004 * * *$ \\
\hline HHI_3 & 3.78 & 4.32 & $0,005 * * *$ & 3.70 & 4.44 & $0,005 * * *$ & 3.69 & 4.37 & $0,024 * *$ & 3.91 & 4.55 & $0,033 * *$ \\
\hline C4_3 & 3.53 & 4.32 & $0,000 * * *$ & 4.13 & 3.59 & $0,049 * *$ & 3.49 & 4.22 & $0,022 * *$ & & & \\
\hline NCOMP_4 & 3.78 & 4.40 & $0,002 * * *$ & 3.96 & 4.38 & $0,069 *$ & 3.94 & 4.41 & $0,082 *$ & & & \\
\hline \multirow[t]{2}{*}{ NCOMP_3 } & 3.75 & 4.52 & $0,000 * * *$ & 3.85 & 4.67 & $0,002 * * *$ & 3.79 & 4.47 & $0,027 * *$ & & & \\
\hline & \multicolumn{12}{|c|}{ Painel B: Sub-índice de Dsclosure (DISC) } \\
\hline HHI_4 & 3.65 & 4.85 & $0,002 * * *$ & 4.26 & 5.07 & 0.101 & 4.22 & 5.36 & $0,042 * *$ & 3.65 & 4.96 & $0,004 * * *$ \\
\hline HHI_3 & 3.71 & 4.88 & $0,003 * * *$ & 3.73 & 4.99 & $0,017 * *$ & 3.77 & 4.92 & $0,058^{*}$ & 3.99 & 5.21 & $0,041 * *$ \\
\hline C4_3 & 3.40 & 4.78 & $0,003 * * *$ & 3.64 & 4.26 & 0.328 & 3.50 & 4.55 & 0.132 & & & \\
\hline NCOMP_4 & 3.82 & 4.87 & $0,010 * * *$ & 4.26 & 4.81 & 0.241 & 4.06 & 4.95 & 0.102 & & & \\
\hline \multirow[t]{2}{*}{ NCOMP_3 } & 3.73 & 5.17 & $0,001 * * *$ & 3.89 & 5.43 & $0,004 * * *$ & 3.88 & 4.88 & $0,085^{*}$ & & & \\
\hline & \multicolumn{12}{|c|}{ Painel C: Sub-índice de Composição e Funcionamento do Conselho (BOARD) } \\
\hline HHI_4 & 5.09 & 5.46 & 0.226 & 5.15 & 5.57 & 0.273 & 4.98 & 5.72 & $0,095^{*}$ & 5.03 & 5.5 & 0.170 \\
\hline HHI_3 & 4.88 & 5.78 & $0,003 * * *$ & 4.67 & 6.12 & $0,001 * * *$ & 4.55 & 5.89 & $0,005 * * *$ & 5.05 & 5.85 & $0,095^{*}$ \\
\hline C4_3 & 4.63 & 5.77 & $0,002 * * *$ & 4.42 & 5.82 & $0,008 * * *$ & 4.39 & 5.87 & $0,006 * * *$ & & & \\
\hline NCOMP_4 & 5.11 & 5.52 & 0.207 & 5.27 & 5.71 & 0.250 & 5.09 & 5.78 & 0.104 & & & \\
\hline \multirow[t]{2}{*}{ NCOMP_3 } & 5.00 & 5.78 & $0,180 * *$ & 4.97 & 6.3 & $0,003 * * *$ & 4.83 & 5.80 & $0,056^{*}$ & & & \\
\hline & \multicolumn{12}{|c|}{ Painel D: Sub-índice de Ética e Conflito de interesses (ETHICS) } \\
\hline HHI_4 & 1.44 & 1.90 & $0,076^{*}$ & 1.23 & 2.09 & $0,009 * * *$ & 1.14 & 2.04 & $0,011 * * *$ & 1.41 & 2.06 & $0,035^{* *}$ \\
\hline HHI_3 & 1.50 & 1.87 & 0.165 & 1.25 & 1.65 & 0.206 & 1.23 & 1.94 & $0,066^{*}$ & 1.64 & 2.19 & 0.171 \\
\hline C4_3 & 1.29 & 2.07 & $0,016^{* *}$ & 1.26 & 1.92 & $0,059 *$ & 1.05 & 1.89 & $0,045^{* *}$ & & & \\
\hline NCOMP_4 & 1.33 & 2.22 & $0,001 * * *$ & 1.41 & 2.11 & $0,015^{* *}$ & 1.60 & 2.16 & $0,096^{*}$ & & & \\
\hline \multirow[t]{2}{*}{ NCOMP_3 } & 1.41 & 2.15 & $0,021 * *$ & 1.36 & 1.61 & 0.431 & 1.31 & 1.89 & 0.181 & & & \\
\hline & \multicolumn{12}{|c|}{ Painel E: Sub-índice de Direito dos Acionistas (RIGHTS) } \\
\hline HHI_4 & 4.31 & 4.34 & 0.895 & 4.47 & 4.29 & 0.557 & 4.57 & 4.20 & 0.272 & 4.32 & 4.31 & 0.966 \\
\hline HHI_3 & 4.50 & 4.08 & $0,059 *$ & 4.57 & 4.1 & $0,091 *$ & 4.65 & 4.03 & $0,084 *$ & 4.40 & 4.26 & 0.698 \\
\hline C4_3 & 4.30 & 4.03 & 0.273 & 4.48 & 3.97 & $0,093 *$ & 4.49 & 3.97 & 0.147 & & & \\
\hline NCOMP_4 & 4.29 & 4.38 & 0.706 & 4.27 & 4.25 & 0.958 & 4.44 & 4.11 & 0.303 & & & \\
\hline NCOMP_3 & 4.42 & 4.29 & 0.838 & 4.59 & 4.47 & 0.720 & 4.55 & 4.63 & 0.814 & & & \\
\hline
\end{tabular}

Esta tabela reporta um conjunto de testes paramétricos t de Student para amostras independentes, a fim de comparar as médias do IGOV de companhias em setores com alta competição e companhias em setores com baixa competição. O IGOV e seus subíndices, DISC, BOARD, ETHIC e RIGHTS, são mensurados conforme a seção 3.2.1 e as variáveis de competição no mercado de produtos, HHI_4, HHI_3, C4_3, NCOMP_4, NCOMP_3, são mensuradas conforme a seção 3.2.2, para os anos de 2005 a 2007. ***, ** e * denotam a significância estatística das estimativas nos níveis de $1 \%, 5 \%$ e 10\%, respectivamente.

O Painel A da Tabela 13 traz resultados interessantes. Independentemente do critério de definição de se um setor é ou não competitivo, quase todas as variáveis de competição apresentaram diferença estatisticamente significativas, sendo que as firmas em setores classificados como competitivos apresentaram sistematicamente menor qualidade de governança corporativa de governança do que firmas que operam em mercados menos competitivos. Com relação aos demais painéis, a mesma tendência é notada. 
O Painel E é o único a retornar resultados com o sentido oposto aos demais. Especificamente, os resultados sugerem que os direitos dos acionistas são maiores em ambientes mais competitivos, tendo como proxy de competição a variável HHI_3. Esse resultado é significante a $10 \%$ e robusto a diferentes formas de classificar o setor em competitivo ou não. Na Tabela 11, matriz de correlações, o subíndice RIGHTS já havia retornado um resultado com o sentido diferente dos demais. Sendo assim, estudos específicos sobre o direito dos acionistas podem constituir um bom caminho para pesquisas.

A argumentação do trabalho de Allen e Galen (1999) sugere que competição e governança corporativa são mecanismos disciplinadores substitutos. Ou seja, ambientes competitivos tenderiam a naturalmente disciplinar as ações dos gestores. Logo, os resultados preliminares contidos na Tabela 13 reforçam a idéia de que há uma relação de substituição entre competição no mercado de produtos e qualidade de governança corporativa. Do ponto de vista empírico, os resultados vão ao encontro dos achados de Chou et al (2008). Contudo, são contraditórios com os achados de Karuna (2008), pois este obtém em seu estudo uma relação positiva entre competição e governança.

Não obstante os resultados preliminares sugerirem uma influência da competição sobre as práticas de governança, as evidências precisam ser estudadas por meio de modelos mais robustos, que contemplem controles de potenciais determinantes da qualidade de governança corporativa das companhias.

Inicialmente, são estimados modelos pelo método dos Mínimos Quadrados Ordinários, apesar dos potenciais problemas desse método, como comentado na seção 3.7. Sem desconsiderar as inerentes limitações do método MQO, os resultados desse modelo são úteis para futuras comparações. Na Tabela 14 são apresentadas as estimativas. 
Tabela 14 - Efeitos da competição no mercado de produtos sobre a qualidade de governança das companhias: regressões utilizando o método MQO

\begin{tabular}{|c|c|c|c|c|c|}
\hline \multirow[b]{2}{*}{ Regressores } & \multicolumn{5}{|c|}{ Variável dependente = IGOV } \\
\hline & (i) & (ii) & (iii) & (iv) & (v) \\
\hline HHI_4 & $\begin{array}{l}-0.390 \\
(0.649)\end{array}$ & & & & \\
\hline HHI_3 & & $\begin{array}{l}-0.877 \\
(0.914)\end{array}$ & & & \\
\hline $\mathrm{C} 4 \_3$ & & & $\begin{array}{c}0.091 \\
(0.581)\end{array}$ & & \\
\hline NCOMP_4 & & & & $\begin{array}{c}0.000 \\
(0.000)\end{array}$ & \\
\hline NCOMP_3 & & & & & $\begin{array}{c}0.001 \\
(0.000)\end{array}$ \\
\hline 3VDIR & $\begin{array}{l}-1.226 \\
(0.787)\end{array}$ & $\begin{array}{l}-1.197 \\
(0.769)\end{array}$ & $\begin{array}{l}-0.642 \\
(0.865)\end{array}$ & $\begin{array}{l}-1.237 \\
(0.775)\end{array}$ & $\begin{array}{l}-1.149 \\
(0.753)\end{array}$ \\
\hline VOTE & $\begin{array}{l}1.056^{*} \\
(0.545)\end{array}$ & $\begin{array}{c}1.080 * * \\
(0.543)\end{array}$ & $\begin{array}{c}0.399 \\
(0.582)\end{array}$ & $\begin{array}{l}1.037 * \\
(0.529)\end{array}$ & $\begin{array}{c}1.034 * * \\
(0.516)\end{array}$ \\
\hline CRESC & $\begin{array}{c}0.074 * \\
(0.0429)\end{array}$ & $\begin{array}{c}0.074 * \\
(0.0426)\end{array}$ & $\begin{array}{c}0.076 \\
(0.0457)\end{array}$ & $\begin{array}{c}0.073 * \\
(0.0425)\end{array}$ & $\begin{array}{c}0.075^{*} \\
(0.0427)\end{array}$ \\
\hline LEV & $\begin{array}{c}0.0556 * * * \\
(0.0151)\end{array}$ & $\begin{array}{c}0.0560^{* * *} \\
(0.0153)\end{array}$ & $\begin{array}{c}0.0603 * * * \\
(0.0201)\end{array}$ & $\begin{array}{c}0.0536 * * * \\
(0.0149)\end{array}$ & $\begin{array}{c}0.0528 * * * \\
(0.0152)\end{array}$ \\
\hline TANG & $\begin{array}{l}-0.816 \\
(0.823)\end{array}$ & $\begin{array}{l}-0.877 \\
(0.841)\end{array}$ & $\begin{array}{l}-0.343 \\
(0.844)\end{array}$ & $\begin{array}{l}-0.842 \\
(0.822)\end{array}$ & $\begin{array}{l}-0.763 \\
(0.827)\end{array}$ \\
\hline SIZE & $\begin{array}{c}0.368^{* * *} * \\
(0.0700)\end{array}$ & $\begin{array}{c}0.366 * * * \\
(0.0709)\end{array}$ & $\begin{array}{c}0.343 * * * \\
(0.0706)\end{array}$ & $\begin{array}{c}0.361 * * * \\
(0.0708)\end{array}$ & $\begin{array}{c}0.355^{* * * *} \\
(0.0709)\end{array}$ \\
\hline DIVYELD & $\begin{array}{l}-0.650 \\
(1.892)\end{array}$ & $\begin{array}{l}-0.686 \\
(1.908)\end{array}$ & $\begin{array}{l}1.308 \\
(2.365)\end{array}$ & $\begin{array}{l}-0.534 \\
(1.885)\end{array}$ & $\begin{array}{l}-0.215 \\
(1.918)\end{array}$ \\
\hline AGE & $\begin{array}{l}-0.00268 \\
(0.00477)\end{array}$ & $\begin{array}{l}-0.00274 \\
(0.00484)\end{array}$ & $\begin{array}{r}-0.000816 \\
(0.00493)\end{array}$ & $\begin{array}{l}-0.00202 \\
(0.00485)\end{array}$ & $\begin{array}{l}-0.00174 \\
(0.00479)\end{array}$ \\
\hline ADR23 & $\begin{array}{c}-0.0667 \\
(0.470)\end{array}$ & $\begin{array}{c}-0.0676 \\
(0.456)\end{array}$ & $\begin{array}{c}0.200 \\
(0.477)\end{array}$ & $\begin{array}{l}-0.141 \\
(0.461)\end{array}$ & $\begin{array}{l}-0.0910 \\
(0.451)\end{array}$ \\
\hline $\mathrm{N} 2 \mathrm{NM}$ & $\begin{array}{l}0.790 * \\
(0.428)\end{array}$ & $\begin{array}{l}0.800 * \\
(0.428)\end{array}$ & $\begin{array}{c}0.464 \\
(0.494)\end{array}$ & $\begin{array}{l}0.785^{*} \\
(0.434)\end{array}$ & $\begin{array}{l}0.831 * \\
(0.424)\end{array}$ \\
\hline Intercepto & $\begin{array}{l}-0.713 \\
(1.350)\end{array}$ & $\begin{array}{l}-0.293 \\
(1.462)\end{array}$ & $\begin{array}{l}-1.282 \\
(1.468)\end{array}$ & $\begin{array}{l}-0.416 \\
(1.443)\end{array}$ & $\begin{array}{l}-0.300 \\
(1.449)\end{array}$ \\
\hline Dummies IDENT & SIM & SIM & SIM & SIM & SIM \\
\hline Dummies IND & SIM & SIM & SIM & SIM & SIM \\
\hline Dummies ANO & SIM & SIM & SIM & SIM & SIM \\
\hline Número de obs ervações & 216 & 216 & 144 & 216 & 216 \\
\hline $\mathbf{R}^{2}$ & 0.577 & 0.578 & 0.532 & 0.578 & 0.582 \\
\hline
\end{tabular}

A variável dependente é o IGOV apresentado na seção 3.2.1 e é referente aos anos de 2005 a 2007. Os regressores são: HHI_4 (HHI calculado pela CNAE a 4 dígitos), HHI_3 (HHI calculado pela CNAE a 3 dígitos), C4_3 (C4 calculado pela CNAE a 3 dígitos), NCOMP_4 (Competidores considerando CNAE a 4 dígitos), NCOMP_3 (Competidores considerando CNAE a três dígitos), 3VDIR (ações ordinárias do três principais acionistas), VOTE (participação das ações ordinárias no capital total da companhia), CRESC (crescimento), LEV (alavancagem), TANG (tangibilidade), SIZE (tamanho), DIVYELD (taxa de dividendos), AGE (idade), ADR23 (emissoras de ADRs II e III), N2NM (listadas nos níveis diferenciados de governança corporativa da Bolsa, especificamente no Nível II ou Novo Mercado) e os conjuntos de dummies IDENT (tipo do acionista controlador), IND (setor de atuação da companhia), ANO. As definições operacionais constam da seção 3.3. O erro-padrão de cada coeficiente figura entre parênteses. $* * *, * *$ e * denotam a significância estatística das 
estimativas nos níveis de $1 \%, 5 \%$ e $10 \%$, respectivamente. Os erros-padrão foram calculados, para todos os métodos de estimação, utilizando-se os dados agrupados por empresa e são robustos a quaisquer formas de heterocedasticidade e autocorrelação dos erros do modelo.

As estimativas, na Tabela 14, não permitem inferir claramente sobre o relacionamento entre as variáveis de competição e qualidade de governança corporativa das companhias. A variável HHI_4 apresentou um coeficiente negativo -0,39, sugerindo que o aumento da concentração, que para os propósitos da pesquisa significa diminuição da competição, tende a reduzir a qualidade de governança das companhias. Contudo, o resultado não é estatisticamente significativo, como pode ser avaliado por meio da divisão do coeficiente pelo erro-padrão.

A variável HHI_3 apresentou o mesmo comportamento de HHI_4, ou seja, aumento de concentração está relacionado com diminuição da qualidade de governança, todavia o resultado não tem significância estatística. Comparativamente, os resultados concordam com os de Karuna (2008), na medida em que o autor identifica uma relação positiva entre governança e competição. Contudo, como os coeficientes não possuem significância estatística, as análises devem ser feitas com extrema cautela.

A variável C4_3 apresenta comportamento diverso em relação à HHI_3 e HHI_4. O coeficiente da variável indica que o aumento da concentração tende aumentar a qualidade de governança corporativa das companhias. No entanto, o coeficiente não possui significância estatística. Em relação às variáveis NCOMP_4 e NCOMP_3, o efeito sobre a qualidade de governança mostra-se praticamente nulo.

No modelo de MQO, a heterogeneidade não observada é desconsiderada nas estimações. Para avaliar sua relevância, foi empregado o teste de Multiplicador de Lagrange de Breusch-Pagan. No teste, a hipótese nula é que o efeito específico não tenha relevância. Na Tabela 15, tem-se que o teste de Breusch-Pagan apontou para a necessidade de os efeitos específicos serem considerados nos modelos, ao nível de significância de $1 \%$.

Na Tabela 15 são apresentados os resultados dos modelos por meio da estimação com base no procedimento conhecido como efeitos aleatórios. 
Tabela 15 - Efeitos da competição no mercado de produtos sobre a qualidade de governança das companhias: regressões utilizando o método de Efeitos Aleatórios Variável dependente $=$ IGOV

\begin{tabular}{|c|c|c|c|c|c|}
\hline Regressores & (i) & (ii) & (iii) & (iv) & (v) \\
\hline HHI_4 & $\begin{array}{l}-0.346 \\
(0.528)\end{array}$ & & & & \\
\hline HHI_3 & & $\begin{array}{l}-0.653 \\
(0.809)\end{array}$ & & & \\
\hline C4_3 & & & $\begin{array}{l}-0.629 \\
(0.660)\end{array}$ & & \\
\hline NCOMP_4 & & & & $\begin{array}{l}0.0005^{*} \\
(0.0003)\end{array}$ & \\
\hline NCOMP_3 & & & & & $\begin{array}{c}0.00001 * * \\
(0.00003)\end{array}$ \\
\hline 3VDIR & $\begin{array}{l}-1.135 \\
(1.063)\end{array}$ & $\begin{array}{l}-1.125 \\
(1.060)\end{array}$ & $\begin{array}{l}-1.082 \\
(0.686)\end{array}$ & $\begin{array}{l}-1.186 \\
(1.079)\end{array}$ & $\begin{array}{l}-1.112 \\
(1.039)\end{array}$ \\
\hline VOTE & $\begin{array}{l}1.661 * \\
(0.885)\end{array}$ & $\begin{array}{l}1.670 * \\
(0.880)\end{array}$ & $\begin{array}{c}1.151 \\
(0.768)\end{array}$ & $\begin{array}{l}1.711^{*} \\
(0.894)\end{array}$ & $\begin{array}{l}1.675^{*} \\
(0.876)\end{array}$ \\
\hline CRESC & $\begin{array}{c}0.0328 \\
(0.0289)\end{array}$ & $\begin{array}{c}0.0327 \\
(0.0286)\end{array}$ & $\begin{array}{c}0.0403 \\
(0.0369)\end{array}$ & $\begin{array}{c}0.0320 \\
(0.0284)\end{array}$ & $\begin{array}{c}0.0317 \\
(0.0286)\end{array}$ \\
\hline LEV & $\begin{array}{c}0.0395 * * \\
(0.0156)\end{array}$ & $\begin{array}{c}0.0386^{* *} \\
(0.0155)\end{array}$ & $\begin{array}{c}0.0590 * * * \\
(0.0204)\end{array}$ & $\begin{array}{c}0.0375^{* *} \\
(0.0151)\end{array}$ & $\begin{array}{c}0.0378 * * \\
(0.0151)\end{array}$ \\
\hline TANG & $\begin{array}{l}-1.078 \\
(0.871)\end{array}$ & $\begin{array}{l}-1.106 \\
(0.880)\end{array}$ & $\begin{array}{l}-0.594 \\
(0.743)\end{array}$ & $\begin{array}{l}-1.127 \\
(0.880)\end{array}$ & $\begin{array}{l}-1.099 \\
(0.875)\end{array}$ \\
\hline SIZE & $\begin{array}{c}0.304 * * * \\
(0.0792)\end{array}$ & $\begin{array}{c}0.301 * * * \\
(0.0796)\end{array}$ & $\begin{array}{c}0.302 * * * \\
(0.0719)\end{array}$ & $\begin{array}{c}0.293 * * * \\
(0.0793)\end{array}$ & $\begin{array}{c}0.289 * * * \\
(0.0778)\end{array}$ \\
\hline DIVYELD & $\begin{array}{l}-1.029 \\
(0.943)\end{array}$ & $\begin{array}{l}-1.041 \\
(0.938)\end{array}$ & $\begin{array}{l}-0.262 \\
(1.822)\end{array}$ & $\begin{array}{l}-0.990 \\
(0.935)\end{array}$ & $\begin{array}{l}-0.933 \\
(0.932)\end{array}$ \\
\hline AGE & $\begin{array}{l}-0.00550 \\
(0.00500)\end{array}$ & $\begin{array}{l}-0.00550 \\
(0.00506)\end{array}$ & $\begin{array}{l}-0.00318 \\
(0.00509)\end{array}$ & $\begin{array}{l}-0.00389 \\
(0.00507)\end{array}$ & $\begin{array}{l}-0.00381 \\
(0.00498)\end{array}$ \\
\hline ADR23 & $\begin{array}{l}-0.275 \\
(0.579)\end{array}$ & $\begin{array}{l}-0.290 \\
(0.581)\end{array}$ & $\begin{array}{c}0.416 \\
(0.488)\end{array}$ & $\begin{array}{l}-0.345 \\
(0.602)\end{array}$ & $\begin{array}{l}-0.254 \\
(0.554)\end{array}$ \\
\hline $\mathrm{N} 2 \mathrm{NM}$ & $\begin{array}{c}0.842 \\
(0.527)\end{array}$ & $\begin{array}{c}0.845 \\
(0.527)\end{array}$ & $\begin{array}{c}0.473 \\
(0.478)\end{array}$ & $\begin{array}{c}0.828 \\
(0.536)\end{array}$ & $\begin{array}{l}0.883^{*} \\
(0.524)\end{array}$ \\
\hline Intercepto & $\begin{array}{c}0.986 \\
(1.953)\end{array}$ & $\begin{array}{c}0.744 \\
(1.622)\end{array}$ & $\begin{array}{l}-0.0414 \\
(1.409)\end{array}$ & $\begin{array}{c}0.861 \\
(1.961)\end{array}$ & $\begin{array}{c}0.835 \\
(1.945)\end{array}$ \\
\hline Dummies IDENT & SIM & SIM & SIM & SIM & SIM \\
\hline Dummies IND & SIM & SIM & SIM & SIM & SIM \\
\hline Dummies ANO & SIM & SIM & SIM & SIM & SIM \\
\hline Número de obs ervações & 216 & 216 & 144 & 216 & 216 \\
\hline $\begin{array}{l}\mathbf{R}^{2} \\
\text { Breusch-Pagan }\end{array}$ & $\begin{array}{c}0.5428 \\
56.85(0.000)\end{array}$ & $\begin{array}{c}0.5433 \\
56.56(0.000)\end{array}$ & $\begin{array}{c}0.5054 \\
32.56(0.000)\end{array}$ & $\begin{array}{c}0.5424 \\
56.99(0.000)\end{array}$ & $\begin{array}{c}0.5466 \\
57.53(0.000)\end{array}$ \\
\hline
\end{tabular}

A variável dependente é o IGOV apresentado na seção 3.2.1 e referente aos anos de 2005 a 2007. Os regressores são: HHI_4 (HHI calculado pela CNAE a 4 dígitos), HHI_3 (HHI calculado pela CNAE a 3 dígitos), C4_3 (C4 calculado pela CNAE a 3 dígitos), NCOMP_4 (Competidores considerando CNAE a 4 dígitos), NCOMP_3 (Competidores considerando CNAE a três dígitos), 3VDIR (ações ordinárias do três principais acionistas), VOTE (participação das ações ordinárias no capital total da companhia), CRESC (crescimento), LEV (alavancagem), TANG (tangibilidade), SIZE (tamanho), DIVYELD (taxa de dividendos), AGE (idade), ADR23 (emissoras de ADRs II e III), N2NM (listadas nos níveis diferenciados de governança corporativa da Bolsa, especificamente no Nível II ou Novo Mercado) e os conjuntos de dummies IDENT (tipo do acionista controlador), IND (setor de atuação da companhia), ANO. As definições operacionais constam da seção 3.3. O teste do tipo Multiplicador de Lagrange de Breusch-Pagan reportado é um teste de relevância estatística dos 
efeitos específicos não observados. O erro-padrão de cada coeficiente figura entre parênteses. ***,** e * denotam a significância estatística das estimativas nos níveis de $1 \%, 5 \%$ e $10 \%$, respectivamente. Os erros-padrão foram calculados, para todos os métodos de estimação, utilizando-se os dados agrupados por empresa e são robustos a quaisquer formas de heterocedasticidade e autocorrelação dos erros do modelo.

A comparação entre as estimações da Tabela 14 e a Tabela 15 permite observar diferenças nos sinais de algumas variáveis. Uma mudança relevante para os objetivos da pesquisa é que os coeficientes das cinco variáveis de competição passaram a ter a mesma interpretação.

Os coeficientes das variáveis HHI_4 e HHI_3 não sofreram modificações em comparação com os resultados da Tabela 14. Continuam sugerindo que o aumento da concentração tem relação negativa com a qualidade de governança das companhias. Agora, todavia, o coeficiente da variável C4_3 indica a mesma interpretação, pois seu coeficiente passou de positivo para negativo. Porém, os coeficientes estimados das três variáveis não apresentaram significância estatística.

Em complemento, os coeficientes das variáveis NCOMP_4 e NCOMP_3 apresentam significância estatística ao nível de $10 \%$ e 5\%, respectivamente. Por ser positivo, a interpretação do coeficiente é que o aumento no número de competidores tende a elevar a qualidade de governança das companhias. Não obstante, economicamente o efeito do número de competidores sobre governança não é tão relevante, visto que os coeficientes apresentaram valores muito baixos, levando a concluir que o efeito seria substancial apenas se o aumento do número de competidores em um setor fosse elevado. Dada a relativa estabilidade de alguns setores, o resultado perde parte de sua relevância do ponto de vista prático.

A Tabela 16 apresenta os resultados das estimações por meio do procedimento chamado de efeitos fixos. Neste caso, as variáveis sem quaisquer variações no tempo foram excluídas do modelo, bem como as variáveis que se modificam de forma constante de um período para o outro. Assim, AGE, N2NM, ADR23 e IND não constam do modelo abaixo. Wooldridge (2007) explica os motivos para a exclusão de variáveis com essas características em modelos de efeitos fixos. 
Tabela 16 - Efeitos da competição no mercado de produtos sobre a qualidade de governança das companhias: regressões utilizando o método de Efeitos Fixos

\begin{tabular}{|c|c|c|c|c|c|}
\hline \multirow[b]{2}{*}{ Regressores } & \multicolumn{5}{|c|}{ Variável dependente = IGOV } \\
\hline & (i) & (ii) & (iii) & (iv) & (v) \\
\hline HHI_4 & $\begin{array}{c}1.953 \\
(1.275)\end{array}$ & & & & \\
\hline HHI_3 & & $\begin{array}{c}2.586 \\
(1.686)\end{array}$ & & & \\
\hline C4_3 & & & $\begin{array}{c}-7.156 * * \\
(3.128)\end{array}$ & & \\
\hline NCOMP_4 & & & & $\begin{array}{c}0.00650 * * \\
(0.00270)\end{array}$ & \\
\hline NCOMP_3 & & & & & $\begin{array}{c}0.000247 \\
(0.000238)\end{array}$ \\
\hline 3VDIR & $\begin{array}{c}0.704 \\
(1.140)\end{array}$ & $\begin{array}{c}0.758 \\
(1.121)\end{array}$ & $\begin{array}{l}-1.618 \\
(1.091)\end{array}$ & $\begin{array}{c}0.746 \\
(1.138)\end{array}$ & $\begin{array}{c}0.769 \\
(1.133)\end{array}$ \\
\hline VOTE & $\begin{array}{c}4.883^{* * *} * \\
(1.004)\end{array}$ & $\begin{array}{c}4.918 * * * \\
(1.018)\end{array}$ & $\begin{array}{c}2.848 * * * \\
(0.181)\end{array}$ & $\begin{array}{c}4.610 * * * \\
(1.091)\end{array}$ & $\begin{array}{c}4.668 * * * \\
(1.145)\end{array}$ \\
\hline CRESC & $\begin{array}{c}0.0306 \\
(0.0276)\end{array}$ & $\begin{array}{c}0.0285 \\
(0.0275)\end{array}$ & $\begin{array}{c}0.0410 \\
(0.0393)\end{array}$ & $\begin{array}{c}0.0310 \\
(0.0280)\end{array}$ & $\begin{array}{c}0.0241 \\
(0.0294)\end{array}$ \\
\hline LEV & $\begin{array}{l}-0.00514 \\
(0.0221)\end{array}$ & $\begin{array}{c}0.00803 \\
(0.0217)\end{array}$ & $\begin{array}{c}1.822 \\
(1.427)\end{array}$ & $\begin{array}{l}0.00168 \\
(0.0205)\end{array}$ & $\begin{array}{l}0.00696 \\
(0.0213)\end{array}$ \\
\hline TANG & $\begin{array}{l}-1.547 \\
(1.037)\end{array}$ & $\begin{array}{l}-1.479 \\
(1.011)\end{array}$ & $\begin{array}{l}-0.286 \\
(0.742)\end{array}$ & $\begin{array}{l}-1.639 \\
(0.987)\end{array}$ & $\begin{array}{c}-1.692 * \\
(0.962)\end{array}$ \\
\hline SIZE & $\begin{array}{l}-0.188 \\
(0.257)\end{array}$ & $\begin{array}{l}-0.0980 \\
(0.256)\end{array}$ & $\begin{array}{c}0.403 \\
(0.432)\end{array}$ & $\begin{array}{c}-0.0647 \\
(0.251)\end{array}$ & $\begin{array}{l}-0.0835 \\
(0.253)\end{array}$ \\
\hline DIVYELD & $\begin{array}{l}-0.980 \\
(1.112)\end{array}$ & $\begin{array}{c}-0.870 \\
(1.110)\end{array}$ & $\begin{array}{l}-0.605 \\
(1.352)\end{array}$ & $\begin{array}{l}-0.859 \\
(1.113)\end{array}$ & $\begin{array}{l}-0.899 \\
(1.146)\end{array}$ \\
\hline Intercepto & $\begin{array}{c}7.779 * * \\
(3.698)\end{array}$ & $\begin{array}{l}6.656^{*} \\
(3.715)\end{array}$ & $\begin{array}{c}0.238 \\
(5.455)\end{array}$ & $\begin{array}{c}5.572 \\
(3.734)\end{array}$ & $\begin{array}{l}6.344 * \\
(3.701)\end{array}$ \\
\hline Dummies IDENT & SIM & SIM & SIM & SIM & SIM \\
\hline Dummies IND & NÃO & NÃO & NÃO & NÃO & NÃO \\
\hline Dummies ANO & SIM & SIM & SIM & SIM & SIM \\
\hline Número de obs ervações & 216 & 216 & 144 & 216 & 216 \\
\hline $\mathbf{R}^{2}$ & 0.459 & 0.459 & 0.325 & 0.476 & 0.463 \\
\hline
\end{tabular}

A variável dependente é o IGOV apresentado na seção 3.2.1 e refere-se ao período de 2005 a 2007. Os regressores são: HHI_4 (HHI calculado pela CNAE a 4 dígitos), HHI_3 (HHI calculado pela CNAE a 3 dígitos), C4_3 (C4 calculado pela CNAE a 3 dígitos), NCOMP_4 (Competidores considerando CNAE a 4 dígitos), NCOMP_3 (Competidores considerando CNAE a três dígitos), 3VDIR (ações ordinárias do três principais acionistas), VOTE (participação das ações ordinárias no capital total da companhia), CRESC (crescimento), LEV (alavancagem), TANG (tangibilidade), SIZE (tamanho), DIVYELD (taxa de dividendos) e os conjuntos de dummies IDENT (tipo do acionista controlador), IND e ANO. As definições operacionais constam da seção 3.3. O erro-padrão de cada coeficiente figura entre parênteses. ***, ** e * denotam a significância estatística das estimativas nos níveis de 1\%, 5\% e 10\%, respectivamente. Os erros-padrão foram calculados, para todos os métodos de estimação, utilizando-se os dados agrupados por empresa e são robustos a quaisquer formas de heterocedasticidade e autocorrelação dos erros do modelo.

Os resultados da Tabela 16 indicam que as variáveis HHI_4 e HHI_3 não apresentam significância estatística, resultado que já havia sido obtido nos modelos das Tabelas 14 e 15 . 
Entretanto, as variáveis C4_3 e NCOMP_4 apresentam coeficiente estatisticamente significativos. A primeira apresentou um coeficiente negativo de $-7,156$ e a segunda um coeficiente de 0,0065 . Em ambos os casos, a interpretação dos coeficientes sugere que baixos níveis de competição, representada pela alta concentração de mercado e reduzido número de competidores, tende a ter um efeito negativo médio sobre a qualidade de governança corporativa. Contudo, reforça-se novamento o impacto econômico reduzido da variável NCOMP_4

As estimações por EA e EF retornaram resultados distintos. Destarte, é necessário identificar qual dos modelos é mais adequado aos dados da pesquisa. Na Tabela 17, abaixo, o teste generalizado de Hausman para escolher-se entre o procedimento de efeitos fixos e efeitos aleatórios indica que o primeiro é o mais adequado em todos os modelos. Os resultados foram significantes ao nível de $1 \%$.

Tabela 17 - Efeitos sobre a governança corporativa no período de 2005 a 2007: teste generalizado de Hausman para comparação dos estimadores de EA e EF

\begin{tabular}{cccccc}
\hline & (i) & (ii) & (iii) & (iv) & (v) \\
\hline Hausman & $66.867(0.000)$ & $67.356(0.000)$ & $32.292(0.000)$ & $69.869(0.000)$ & $64.68(0.000)$ \\
\hline
\end{tabular}

Em comparação com pesquisas internacionais desenvolvidas sobre o mesmo tema ou correlatos, o painel estimado por meio de efeitos fixos é uma técnica recorrentemente empregada. Exemplos de estudos que utilizam essa técnica são os de: Kole e Lehn (1999), Guadalupe e Pérez-Gonzáles (2006), Rennie (2006), Pattanayak (2008), Cremers et al. (2008), Beiner et al. (2009) e Ammann et al. (2010).

Logo, levando-se em consideração a escolha pelo modelo de efeitos fixos, duas das cinco variáveis utilizadas para aproximar o conceito de competição no mercado de produtos apresentaram resultados significantes e convergentes. Isso enseja que as variáveis de competição, potencialmente, são importantes para explicar a estrutura de governança das companhias.

Não obstante, como forma de averiguar a robustez e estabilidade das conclusões, estimaramse os mesmo modelos, porém para um período diferente e contemplando um índice de governança corporativa distinto. O período refere-se aos anos de 1998 a 2004 e o índice de 
governança corporativa utilizado é o do trabalho de Leal e Carvalhal-da-Silva (2005). O teste de Breusch-Pagan foi utilizado para aferir a relevância de considerar a heterogeneidade não observada e o teste generalizado de Hausman foi empregado para decidir entre os modelos de efeitos fixos e aleatórios. A Tabela 18 apresenta o resultado de ambos os testes.

Tabela 18 - Efeitos sobre a governança corporativa no período de 1998 a2004: teste de Breusch-Pagan e teste generalizado de Hausman para comparação dos estimadores de EA e EF

\begin{tabular}{lccccc}
\hline & (i) & (ii) & (iii) & (iv) & (v) \\
\hline Breusch-Pagan & $67.21(0.000)$ & $152.36(0.000)$ & $148.00(0.000)$ & $67.37(0.000)$ & $68.71(0.000)$ \\
Hausman & $66.867(0.000)$ & $67.356(0.000)$ & $32.292(0.000)$ & $69.869(0.000)$ & $64.68(0.000)$ \\
\hline
\end{tabular}

Pelos resultados da tabela, os efeitos da heterogeneidade não observada são relevantes ao nível de significância de $1 \%$ e o modelo de efeito fixo ${ }^{55}$ é o mais adequado, como evidencia o teste de Hausman. Assim sendo, na Tabela 20 são apresentados os resultados das regressões para o período de 1998 a 2004.

\footnotetext{
${ }^{55}$ Nos modelos de efeitos fixos referentes anos de 1998 a 2004, as variáveis ADR23 e N2NM foram incluídas, pois apresentaram variação nesse período. Algumas empresas emitiram ADRs níveis II e III no período e em 2001 foram criados os segmentos diferenciados de listagem da BM\&FBOVESPA.
} 
Tabela 19 - Efeitos da competição no mercado de produtos sobre a qualidade de governança das companhias: regressões utilizando o método de Efeitos Fixos para o período de 1998 a 2004

\begin{tabular}{|c|c|c|c|c|c|}
\hline \multicolumn{6}{|c|}{ Variável dependente $=$ IGOV } \\
\hline Regressores & (i) & (ii) & (iii) & (iv) & (v) \\
\hline HHI_4 & $\begin{array}{l}-1.874 * \\
(0.961)\end{array}$ & & & & \\
\hline HHI_3 & & $\begin{array}{l}-1.887 \\
(1.143)\end{array}$ & & & \\
\hline C4_3 & & & $\begin{array}{l}-0.694 \\
(0.629)\end{array}$ & & \\
\hline NCOMP_4 & & & & $\begin{array}{l}0.0000 \\
(0.002)\end{array}$ & \\
\hline NCOMP_3 & & & & & $\begin{array}{c}0.0002 \\
(-0.0002)\end{array}$ \\
\hline 3VDIR & $\begin{array}{c}-2.460 * * * \\
(0.839)\end{array}$ & $\begin{array}{l}-1.281^{*} \\
(0.652)\end{array}$ & $\begin{array}{c}-1.263^{*} \\
(0.650)\end{array}$ & $\begin{array}{c}-2.439 * * * \\
(0.869)\end{array}$ & $\begin{array}{c}-2.223 * * \\
(0.858)\end{array}$ \\
\hline VOTE & $\begin{array}{c}-0.000433 \\
(0.660)\end{array}$ & $\begin{array}{l}0.0685 \\
(0.277)\end{array}$ & $\begin{array}{l}0.0722 \\
(0.290)\end{array}$ & $\begin{array}{c}0.286 \\
(0.671)\end{array}$ & $\begin{array}{c}0.145 \\
(0.605)\end{array}$ \\
\hline CRESC & $\begin{array}{c}0.251 \\
(0.406)\end{array}$ & $\begin{array}{c}0.176 \\
(0.255)\end{array}$ & $\begin{array}{c}0.140 \\
(0.248)\end{array}$ & $\begin{array}{c}0.125 \\
(0.396)\end{array}$ & $\begin{array}{c}0.183 \\
(0.333)\end{array}$ \\
\hline LEV & $\begin{array}{c}0.357 \\
(0.314)\end{array}$ & $\begin{array}{l}0.0478 \\
(0.114)\end{array}$ & $\begin{array}{l}0.0539 \\
(0.115)\end{array}$ & $\begin{array}{c}0.341 \\
(0.344)\end{array}$ & $\begin{array}{c}0.219 \\
(0.301)\end{array}$ \\
\hline TANG & $\begin{array}{l}0.373^{*} \\
(0.195)\end{array}$ & $\begin{array}{c}0.190 \\
(0.117)\end{array}$ & $\begin{array}{l}0.207^{*} \\
(0.121)\end{array}$ & $\begin{array}{c}0.361 \\
(0.218)\end{array}$ & $\begin{array}{c}0.245 \\
(0.196)\end{array}$ \\
\hline SIZE & $\begin{array}{c}0.00910 \\
(0.173)\end{array}$ & $\begin{array}{c}0.164 \\
(0.125)\end{array}$ & $\begin{array}{c}0.183 \\
(0.120)\end{array}$ & $\begin{array}{l}0.0255 \\
(0.174)\end{array}$ & $\begin{array}{l}0.0242 \\
(0.160)\end{array}$ \\
\hline DIVYELD & $\begin{array}{l}-0.0201 \\
(0.750)\end{array}$ & $\begin{array}{l}-0.219 \\
(0.497)\end{array}$ & $\begin{array}{l}-0.192 \\
(0.500)\end{array}$ & $\begin{array}{l}-0.148 \\
(0.813)\end{array}$ & $\begin{array}{l}-0.0975 \\
(0.769)\end{array}$ \\
\hline ADR23 & $\begin{array}{c}0.773 * * * \\
(0.134)\end{array}$ & $\begin{array}{c}0.291 \\
(0.235)\end{array}$ & $\begin{array}{c}0.307 \\
(0.245)\end{array}$ & $\begin{array}{c}0.727 * * * \\
(0.142)\end{array}$ & $\begin{array}{c}0.639 * * * \\
(0.132)\end{array}$ \\
\hline N2NM & $\begin{array}{c}2.271 * * * \\
(0.420)\end{array}$ & $\begin{array}{c}2.467 * * * \\
(0.396)\end{array}$ & $\begin{array}{c}2.347 * * * \\
(0.311)\end{array}$ & $\begin{array}{c}2.237 * * * \\
(0.266)\end{array}$ & $\begin{array}{c}2.207 * * * \\
(0.232)\end{array}$ \\
\hline Intercepto & $\begin{array}{c}6.543 * * * \\
(2.172)\end{array}$ & $\begin{array}{l}2.987^{*} \\
(1.693)\end{array}$ & $\begin{array}{l}2.777^{*} \\
(1.640)\end{array}$ & $\begin{array}{c}5.897 * * * \\
(2.242)\end{array}$ & $\begin{array}{r}4.834 * * \\
(2.001)\end{array}$ \\
\hline Dummies IDENT & $\operatorname{SIM}_{\tilde{\sim}}$ & $\operatorname{SIM}$ & SIM & SIM & SIM \\
\hline Dummies IND & NÃO & NÃO & NÃO & NÃO & NÃO \\
\hline Dummies ANO & SIM & SIM & SIM & SIM & SIM \\
\hline Número de obs ervações & 212 & 304 & 304 & 212 & 231 \\
\hline $\mathbf{R}^{2}$ & 0.582 & 0.522 & 0.517 & 0.565 & 0.552 \\
\hline
\end{tabular}

A variável dependente é o IGOV apresentado na seção 3.2.1 e refere-se ao período de 1998 a 2004. Os regressores são: HHI_4 (HHI calculado pela CNAE a 4 dígitos), HHI_3 (HHI calculado pela CNAE a 3 dígitos), C4_3 (C4 calculado pela CNAE a 3 dígitos), NCOMP_4 (Competidores considerando CNAE a 4 dígitos), NCOMP_3 (Competidores considerando CNAE a três dígitos), 3VDIR (ações ordinárias do três principais acionistas), VOTE (participação das ações ordinárias no capital total da companhia), CRESC (crescimento), LEV (alavancagem), TANG (tangibilidade), SIZE (tamanho), DIVYELD (taxa de dividendos), ADR23 (emissoras de ADRs II e III), N2NM (listadas nos níveis diferenciados de governança corporativa da Bolsa, especificamente no Nível II ou Novo Mercado) e os conjuntos de dummies IDENT (tipo do acionista controlador), IND e ANO. As definições operacionais constam da seção 3.3. O erro-padrão de cada coeficiente figura entre parênteses. ***, ** e * denotam a significância estatística das estimativas nos níveis de 1\%, 5\% e 10\%, 
respectivamente. Os erros-padrão foram calculados, para todos os métodos de estimação, utilizando-se os dados agrupados por empresa e são robustos a quaisquer formas de heterocedasticidade e autocorrelação dos erros do modelo.

Inicialmente, é válido salientar que as variáveis HHI_4, NCOMP_4 e NCOMP_3 estão disponíveis de 2000 a 2004 e as variáveis HHI_3 e C4_3 de 1998 a 2004. Quanto aos resultados propriamente ditos, a variável HHI_4 apresenta significância estatística a 10\%. A interpretação do coeficiente negativo de 1, 874 sugere que o aumento da competição está relacionado como o aumento da qualidade de governança corporativa. Esse resultado é semelhante ao obtido para a variável C4_3 no teste realizado para os anos de 2005 a 2007.

As variáveis HHI_3, C4_3, NCOMP_4 e NCOMP_3 possuem interpretação semelhante. A variável HHI_3 apresenta coeficiente negativo de 1,887, semelhante em termos de grandeza ao da variável HHI_4, porém seu coeficiente não apresenta significância estatística. O coeficiente da variável C4_3 manteve o mesmo sinal em relação ao teste principal feito nos de 2005 e 2007, porém perdeu significância estatística. De forma geral, os resultados obtidos nos testes de robustez não alteram as conclusões extraídas do teste principal da pesquisa.

Nesse ponto, vale retomar a primeira questão de pesquisa enunciada na seção 1.3: A competição no mercado de produtos afeta significativamente a qualidade de governança corporativa das companhias brasileiras com ações listadas na BMF\&BOVESPA?

As análises exploratórias, por meio de gráficos, matrizes de correlações e testes de diferenças de média, evidenciam que a competição no mercado de produtos se relaciona de forma negativa com a qualidade de governança corporativa das companhias. Tais resultados encontram respaldo, principalmente, nos trabalhos de Chou et al. (2008). No entanto, nessas análises exploratórias a possibilidade de problemas advindos da omissão de variáveis é alta. Conforme discutido, o tamanho pode ser uma dessas variáveis. Quando se exclui a influência do tamanho sobre o índice de governança corporativa, os resultados mostram que, intrinsecamente, as empresas em setores menos competitivos são na verdade menos alinhadas às boas práticas de governança corporativa do que as demais. Isso é captado pela a aplicação de técnicas econométricas relativamente mais complexas do que correlações e diferenças de médias. Estas análises indicam que quanto menor o grau de competição no mercado de produtos, menor a governança corporativa das companhias. Especificamente, as variáveis C4_3 e NCOMP_4, para os anos de 2005 e 2007, e a variável HHI_4, nos testes de robustez 
contemplando o período de 1998 a 2004. Em relação à literatura analisada, essa conclusão é próxima da obtida por Karuna (2008) e implica que o relacionamento entre competição e governança é de complementaridade. Todavia, os resultados precisam ser analisados com cautela, visto que nem todas as variáveis de competição utilizadas na pesquisa apresentaram significância e, portanto, não é possível identificar com certeza o sentido desse relacionamento. De qualquer modo, o fato de algumas das variáveis de competição utilizadas nos modelos apresentarem resultados estatisticamente significativos sugere que são potenciais determinantes da qualidade de governança corporativa e que podem ser empregadas em futuras pesquisas sobre o tema.

Assim, retomando as hipóteses também apresentadas na seção 1.3, há condições de rejeitar a hipótese nula de que as variáveis de competição no mercado de produtos não afetam a qualidade de governança corporativa. Com relação às hipóteses alternativas, como explicado acima, são necessárias mais evidências para decidir-se entre a hipótese alternativas 1 e 2 .

\subsection{Efeitos da interação entre competição governança sobre o desempenho}

São diversos os trabalhos que avaliam o efeito da interação entre competição no mercado de produtos e governança sobre o desempenho da companhia. Januszewski et al. (2001), Grosfeld e Tressel (2001), Griffith (2001), Koke e Renneboog (2003), Bozec (2005), Li e Niu (2006), Giroud e Mueller (2008) e, mais recentemente, Ammann et al. (2010) representam essa diversidade de estudos. Fundamentalmente, essas pesquisas avaliam se há algum efeito diferenciado da governança sobre o desempenho das companhias em função do nível de competição do mercado. A motivação teórica para esses estudos pode ser encontrada em Stiglitz e Nalebuff (1983), Hart (1983), Scharfstein (1988), Hermalin (1992) e Schimidt (1997) e Allen e Gale (1999). Neste último, os autores modelam a hipótese que competição substitui governança corporativa como um mecanismo indutor do desempenho organizacional.

A questão fundamental nesses artigos é a seguinte: todas as firmas se beneficiam de boas práticas de governança corporativa? O trabalho de Allen e Gale (1999) apresentado em 2.3 enseja este questionamento, pois, de acordo com o modelo teórico desenvolvido pelos 
autores, em ambientes competitivos os mecanismos de governança corporativa seriam substituídos pelo poder disciplinador da competição. A idéia é que o efeito da governança sobre o desempenho das companhias varie em função do grau de competição no ambiente no qual a firma opere. Logo, como estratégia empírica para tentar responder esse questionamento, inseriu-se um termo de interação entre as variáveis de governança corporativa e as variáveis de competição no mercado de produtos. A inclusão de um termo de interação, como apresentado no modelo 2, é adequado para o propósito da pesquisa. Friedrich (1982), Hardy (1993) e Brambor et al. (2005), em conjunto, explicam que os pesquisadores poderiam incluir termos de interação em seus modelos se tiverem uma hipótese condicional, ou seja, se, por exemplo, suporem que um aumento da variável $\mathrm{X}$ é associado com um aumento em $\mathrm{Y}$ quando $\mathrm{Z}$ está presente, mas não quando $\mathrm{Z}$ está ausente. Nesta parte da dissertação, testa-se se o efeito da qualidade de governança corporativa $(X)$ afeta o desempenho das companhias (Y) de forma diferenciada em função de as empresas operarem em setores mais ou menos competitivos (Z).

Para tanto, foram geradas dummies conforme a distribuição dos valores das cinco variáveis de competição utilizadas na pesquisa. Inicialmente, foram calculados a mediana e tercis das distribuições. Em seguida, classificou-se o setor conforme os valores de corte da mediana e tercis. Os valores das variáveis HHI_4, HHI_3 e C4_3 localizadas na parte superior em relação à mediana ou no último tercil foram identificados como com baixa competição. No caso das variáveis NCOMP_3 e NCOMP_4, setores com números de competidores localizados na parte inferior em relação à mediana ou no primeiro tercil foram caracterizados como de baixa competição. Os valores localizados no segundo tercil, competição moderada, não foram utilizados nas regressões. Os procedimentos descritos para a criação de variáveis binárias como indicativo de competição setorial têm o respaldo dos trabalhos de Kadyrzhanova e Rhodes-Kropf (2007), Giroud e Mueller (2008) e Ammann et al. (2010) e visa a conferir robustez aos resultados da pesquisa.

Também foi utilizada uma forma arbitrária de classificação dos setores em competitivos e não competitivos. Como explicado na seção 3.5, o guia de análise de atos de concentração horizontais norte-americano divide o HHI em três regiões: i) abaixo de 1000, o mercado é pouco concentrado; ii) entre 1000 e 1800, a concentração é considerada moderada; e iii) acima de 1800, o mercado é considerado altamente concentrado. Assim, conforme o HHI de 
cada setor, houve a classificação em uma das categorias apresentadas. Com relação à razão de concentração C4, no Guia do CADE (2001, p. 11) há menção de a SEAE e SDE considerarem que um ato de concentração gera controle suficiente para o exercício do poder de mercado quando o ato tornar a soma da participação de mercado das quatro maiores empresas igual ou superior a $75 \%$ ou a participação da empresa resultante do ato for igual ou superior a $10 \%$ do mercado relevante. Assim, com base no percentual de $75 \%$ para o $\mathrm{C} 4$, criou-se uma variável binária para indicar se um setor possui concentração acima ou abaixo desse valor. Caso o C4 seja maior do que $75 \%$, considera-se que o mercado é concentrado.

Nas regressões, o grupo base é sempre os setores que foram considerados de alta competição. Às variáveis HHI_4, HHI_3, C4_3, NCOMP_4, NCOMP_3, foi adicionada a extensão "LOW" para indicar que se trata de uma variável binária que indica baixa competição. Logo, nas regressões as variáveis aparecem como HHI_4LOW, HHI_3LOW, C4_3LOW, NCOMP_4LOW e NCOMP_3LOW. Na seção 3.2.3, foram apresentadas as quatro variáveis de desempenho utilizadas na pesquisa, a saber: EBIT_AT, EBITDA_AT, EBITDA_REC e TOBINSQ.

Os resultados das estimações dos modelos constam do Apêndice 2, da Tabela 1-A até a Tabela 11-A. Ao todo, foram estimados 52 modelos. Para cada um foi testada a relevância dos efeitos não observados, por meio do teste do tipo Multiplicador de Lagrange de BreuschPagan. Em seguida, aplicou-se o teste de Hausman, conforme explicado na seção 3.6, para identificar o melhor modelo. Na grande maioria dos modelos, a relevância dos efeitos não observados mostrou-se significante e o teste de Hausman indicou a adoção do modelo de efeitos fixos como o mais adequado. Assim, os resultados dos modelos reportados nas Tabelas 1-A até a Tabela 11-A foram estimados por meio do modelo de efeitos fixos.

Optou-se por reportar os modelos como apêndice em razão de o interesse principal dessa parte da pesquisa ser estudar o comportamento dos termos de interação. De acordo com Kam e Franzese Jr. (2003, p. 24-25), para entender corretamente o efeito de um termo de interação é adequado utilizar procedimentos de diferenciação. Assim, Brambor et al. (2005, p. 73) apresentam o exemplo a seguir: 
Modelo $1=\mathrm{Y}=\omega_{0}+\omega_{1} \mathrm{X}+\omega_{2} \mathrm{Z}+\mathrm{u}$

Modelo $2=\beta_{0}+\beta_{1} X+\beta_{2} Z+\beta_{3} X Z+e$

O efeito marginal de X no Modelo 1 é dado por $\frac{\partial Y}{\partial X}=\omega_{1}$. Em comparação, no Modelo 2, que possui um termo de interação, o efeito marginal é dado por $\frac{\partial Y}{\partial X}=\beta_{1}+\beta_{3} Z$. Do exemplo, concluí-se que, em um modelo interativo, o efeito marginal de $\mathrm{X}$ depende da variável de condicionamento Z. Segundo Brambor et al. (2005, p. 74), se um termo de interação é empregado em um modelo, é necessário expressar os resultados de forma diferente das tradicionais tabelas de regressão, pois as informações apresentadas não são suficientes para que o leitor compreenda se a interação entre variáveis é ou não significativa. Kam e Franzese Jr. (2003, p. 61) sugerem que o efeito marginal dos termos de interação seja apresentado por meio de tabelas ou gráficos, o que facilitaria o entendimento do leitor. Na tabela, os autores sugerem que as seguintes informações sejam evidenciadas: i) erro-padrão, ii) estatística t; iii) nível de significância; e iv) intervalos de confiança.

Dessa forma, na pesquisa optou-se por apresentar o efeito marginal da governança corporativa sobre o desempenho das companhias quando as companhias operam em setores de alta competição e quando operam em setores de baixa competição, valendo-se de uma tabela detalhada, como sugerem e Kam e Franzese Jr. (2003), tendo em vista que a apresentação por meio de gráficos seria inviável dado o número de modelos testados.

Na Tabela 20 são reportados os resultados do efeito marginal da variável governança corporativa sobre o desempenho em função da competição, nesse caso obtida por meio da mediana. O modelo i do Painel A corresponde à regressão i da Tabela 1-A. O resultado indica que o efeito marginal da governança corporativa em setores competitivos é negativo em 0,0020. Por outro lado, quando o setor é de baixa competição, a qualidade de governança corporativa apresenta um efeito positivo de 0,0072. Todavia, não é possível aferir se esses resultados são estatisticamente significativos apenas por meio da estatística t reportada na Tabela 1-A. Para construir o intervalo de confiança, é necessário conhecer o erro-padrão, que, nesse caso, é dado pela seguinte equação, conforme Kam e Franzese (2003, p. 46): 


$$
\mathrm{V}\left(\frac{\partial \hat{y}}{\partial \hat{x}}\right)=\mathrm{v}\left(\hat{\beta}_{x}\right)+\mathrm{z}_{2} \mathrm{~V}\left(\hat{\beta}_{x z}\right)+2 \mathrm{zC}\left(\hat{\beta_{x}}, \hat{\beta x z}\right)
$$

As informações sobre $\hat{\beta_{x}}$ e $\hat{\beta_{x z}}$ podem ser obtidas diretamente das tabelas convencionais de regressão. Porém a informação sobre $\mathrm{C}\left(\hat{\beta_{x}}, \hat{\beta x z}\right)$, covariância de $\hat{\beta_{x}}$ e $\hat{\beta_{x z}}$, só pode ser obtida por meio de uma matriz de variância-covariância. De posse desses valores, calcula-se o erro-padrão e, em seguida, o intervalo de confiança, a fim de verificar estatisticamente se o efeito marginal de governança sobre o desempenho das companhias, em função de a empresa operar em um ambiente de alta competição ou baixa competição, é positivo ou negativo. Esse foi o procedimento seguido para todos os modelos ${ }^{56}$.

Na Tabela 20, o critério utilizado para classificar um setor como de alta ou baixa competição foi a mediana, seguindo o trabalho de Kadyrzhanova e Rhodes-Kropf (2007). Os resultados correspondem às informações da Tabela 1-A até a Tabela 4-A. Verifica-se que em nenhuma situação houve diferença significativa quanto aos efeitos da governança corporativa sobre o desempenho das companhias, mesmo com a separação do efeito por competição. Todavia, a separação por meio da mediana pode não refletir adequadamente um "ponto de corte" entre setores mais ou menos competitivos. Portanto, outros critérios podem ser utilizados.

\footnotetext{
${ }^{56} \mathrm{O}$ comando lincom do software Stata foi empregado para obter os resultados.
} 
Tabela 20 - Efeito marginal da qualidade de governança corporativa sobre o desempenho: regressões utilizando o método de Efeitos Fixos para o período de 2005 a 2007 e critério da mediana para separação dos setores

\begin{tabular}{|c|c|c|c|c|c|c|c|c|}
\hline Modelo & $\begin{array}{l}\text { Variável de } \\
\text { competição }\end{array}$ & $\begin{array}{l}\text { Alta/Baixa } \\
\text { competição }\end{array}$ & $\begin{array}{c}\text { Efeito } \\
\text { marginal }\end{array}$ & $\begin{array}{l}\text { Erro-padrão do } \\
\text { efeito marginal }\end{array}$ & Estatística-t & $\mathbf{P}>[\mathbf{t}]$ & \multicolumn{2}{|c|}{$\begin{array}{c}\text { Intervalo de confiança } \\
\qquad 95 \%\end{array}$} \\
\hline \multicolumn{9}{|c|}{ Painel A: Lucro operacional próprio sobre o ativo total (EBIT_AT) } \\
\hline \multirow{2}{*}{ (i) } & \multirow{2}{*}{ HHI_4 } & Alta competição & -0.0020 & 0.0086 & -0.2346 & 0.8147 & -0.0189 & 0.0149 \\
\hline & & Baixa competição & 0.0072 & 0.0961 & 0.0750 & 0.9403 & -0.1823 & 0.1967 \\
\hline \multirow{2}{*}{ (ii) } & \multirow{2}{*}{ HHI_3 } & Alta competição & -0.0036 & 0.0078 & -0.4544 & 0.6500 & -0.0190 & 0.0119 \\
\hline & & Baixa competição & 0.0041 & 0.0115 & 0.3529 & 0.7245 & -0.0187 & 0.0268 \\
\hline \multirow{2}{*}{ (iii) } & \multirow{2}{*}{ C4_3 } & Alta competição & 0.0336 & 0.2493 & 0.1348 & 0.8930 & -0.4597 & 0.5270 \\
\hline & & Baixa competição & 0.0114 & 0.3025 & 0.0377 & 0.9700 & -0.5871 & 0.6098 \\
\hline \multirow{2}{*}{ (iv) } & \multirow{2}{*}{ NCOMP_4 } & Alta competição & 0.0017 & 0.0080 & 0.0080 & 0.9936 & -0.0157 & 0.0159 \\
\hline & & Baixa competição & -0.0043 & 0.1430 & 0.0002 & 0.9999 & -0.2819 & 0.2820 \\
\hline \multirow{2}{*}{ (v) } & \multirow{2}{*}{ NCOMP_3 } & Alta competição & -0.0022 & 0.0067 & -0.3280 & 0.7432 & -0.0154 & 0.0110 \\
\hline & & Baixa competição & 0.0195 & 0.2395 & 0.8961 & 0.3713 & -0.2577 & 0.6870 \\
\hline \multicolumn{9}{|c|}{ Painel B: Geração bruta de caixa sobre o ativo total (EBITDA_AT) } \\
\hline \multirow{2}{*}{ (i) } & \multirow{2}{*}{ HHI_4 } & Alta competição & -0.0053 & 0.0086 & -0.6136 & 0.5402 & -0.0222 & 0.0117 \\
\hline & & Baixa competição & 0.0065 & 0.0080 & 0.8208 & 0.4127 & -0.0092 & 0.0223 \\
\hline \multirow{2}{*}{ (ii) } & \multirow{2}{*}{ HHI_3 } & Alta competição & -0.0032 & 0.0080 & -0.4045 & 0.6863 & -0.0189 & 0.0125 \\
\hline & & Baixa competição & -0.0001 & 0.0115 & -0.0073 & 0.9942 & -0.0228 & 0.0226 \\
\hline \multirow{2}{*}{ (iii) } & \multirow{2}{*}{ C4_3 } & Alta competição & 0.0323 & 0.0263 & 1.2270 & 0.2221 & -0.0198 & 0.0844 \\
\hline & & Baixa competição & -0.0226 & 0.0215 & -1.0512 & 0.2952 & -0.0651 & 0.0199 \\
\hline \multirow{2}{*}{ (iv) } & \multirow{2}{*}{ NCOMP_4 } & Alta competição & -0.0011 & 0.0082 & -0.1389 & 0.8897 & -0.0173 & 0.0150 \\
\hline & & Baixa competição & -0.0066 & 0.1436 & -0.0460 & 0.9633 & -0.2897 & 0.2765 \\
\hline \multirow{2}{*}{ (v) } & & Alta competição & -0.0048 & 0.0069 & -0.6942 & 0.4884 & -0.0183 & 0.0088 \\
\hline & NCOMP_3 & Baixa competição & 0.0161 & 0.2346 & 0.0687 & 0.9453 & -0.4465 & 0.4788 \\
\hline & cro ant & juros & renda & reciação e a & zação sol & ceit & uida $(\mathrm{E}$ & A_REC) \\
\hline (i) & HHI & Alta competição & 0.1290 & 0.1713 & 0.7532 & 0.4523 & -0.2088 & 0.4668 \\
\hline (1) & HHI_4 & Baixa competição & 0.1360 & 0.2208 & 0.6161 & 0.5385 & -0.2994 & 0.5715 \\
\hline (ii) & $\mathrm{HHI}$ & Alta competição & 0.0126 & 0.0167 & 0.7543 & 0.4516 & -0.0203 & 0.0455 \\
\hline (11) & HHI_3 & Baixa competição & 0.0102 & 0.0236 & 0.4324 & 0.6659 & -0.0364 & 0.0568 \\
\hline (iii) & $\mathrm{CH}_{4} 3$ & Alta competição & 0.0457 & 0.0606 & 0.7544 & 0.4520 & -0.0742 & 0.1656 \\
\hline (111) & & Baixa competição & 0.0969 & 0.0731 & 1.3252 & 0.1875 & -0.0478 & 0.2416 \\
\hline (iv) & NCOMP 4 & Alta competição & -0.0217 & 0.0308 & -0.7049 & 0.4817 & -0.0823 & 0.0390 \\
\hline (iv) & NCOMI & Baixa competição & 0.1217 & 0.0921 & 1.3221 & 0.1876 & -0.0598 & 0.3033 \\
\hline (v) & NCOMP 3 & Alta competição & 0.0076 & 0.0148 & 0.5104 & 0.6104 & -0.0217 & 0.0368 \\
\hline (V) & NCUNIP_3 & Baixa competição & 0.0794 & 0.0756 & 1.0504 & 0.2948 & -0.0697 & 0.2285 \\
\hline & & & Painel D & de Tobin (TO & (NSQ) & & & \\
\hline (i) & HHI 4 & Alta competição & 0.0341 & 0.1653 & 0.2063 & 0.8368 & -0.2919 & 0.3601 \\
\hline (1) & HHI_4 & Baixa competição & -0.1199 & 0.2524 & -0.4750 & 0.6353 & -0.6178 & 0.3780 \\
\hline (ii) & HHI 3 & Alta competição & 0.0818 & 0.1578 & 0.5183 & 0.6049 & -0.2295 & 0.3931 \\
\hline (11) & HHI_3 & Baixa competição & -0.2730 & 0.3819 & -0.7149 & 0.4756 & -1.0264 & 0.4804 \\
\hline (iii) & $C_{4} 3$ & Alta competição & 0.0520 & 0.1814 & 0.2866 & 0.7749 & -0.3073 & 0.4113 \\
\hline (111) & C4_3 & Baixa competição & 0.2373 & 0.2272 & 1.0445 & 0.2984 & -0.2126 & 0.6873 \\
\hline (iv & $\mathrm{NCO}$ & Alta competição & -0.1470 & 0.2649 & -0.5547 & 0.5798 & -0.6696 & 0.3757 \\
\hline (iv) & NCOM & Baixa competição & 0.3653 & 0.3022 & 1.2089 & 0.2282 & -0.2308 & 0.9613 \\
\hline$(y)$ & NCOMP 3 & Alta competição & -0.0220 & 0.1699 & -0.1294 & 0.8972 & -0.3571 & 0.3132 \\
\hline (v) & NCUMP_3 & Baixa competição & 0.1977 & 0.3480 & 0.5681 & 0.5706 & -0.4888 & 0.8843 \\
\hline
\end{tabular}


Adicionalmente, a fim de verificar se os resultados se alteram quando o critério para separar os setores em competitivos ou não competitivos é alterado, utiliza-se como critério os tercis, a exemplo de Giroud e Mueller (2008) e Ammann et al. (2010). Na Tabela 21 são apresentados os resultados, com base nas Tabelas 5-A até a Tabela 8-A.

No modelo i do Painel A, que utiliza a variável HHI_4 como um dos regressores, há um resultado estatisticamente significativo. Com a variável EBIT_AT como dependente, o efeito da qualidade de governança corporativa sobre o desempenho é positivo em setores classificados como competitivos, todavia o efeito marginal não é significativo. Em relação aos setores considerados não competitivos, o efeito da qualidade de governança corporativa é positivo e estatisticamente significativo a $5 \%$.

Nesse sentido, o modelo iv do Painel A apresenta resultado semelhante, ou seja, o efeito da qualidade de governança apresentou significância apenas no desempenho de empresas pertencentes a setores não competitivos. Nos modelos i e iv do Painel B, foram identificados efeitos semelhantes. No modelo i, no qual a variável de competição é o HHI_4, governança afeta negativamente o desempenho em setores competitivos, verificado por um coeficiente negativo de 0.010, que não é estatisticamente significativo. Para empresas em setores classificados como de baixa competição, o efeito da governança é positivo e significativo a 5\%. O mesmo ocorre quando a variável de competição utilizada é o NCOMP_4.

Assim, os resultados dos Painéis A e B apresentam coerência no sentido do relacionamento entre as variáveis. Não obstante, no Painel D, quando a variável TOBINSQ é empregada como proxy de desempenho, apenas o modelo iv retorna resultados estatisticamente significativos, a 10\%. Porém, o sentido do relacionamento é invertido em relação ao achados dos Painéis A e B. O efeito da governança sobre desempenho é significativo e negativo apenas para firmas que operam em setores menos competitivos.

Os resultados dos modelos i e iv dos Painéis A e B possuem estreita relação com os achados de Chou et al. (2008), Giroud e Mueller (2008), e Ammann et al.(2010). Em seus trabalhos, por meio de diferentes estratégias empíricas, os autores identificam que a qualidade de governança corporativa está positivamente relacionada com desempenho apenas para empresas com operações em mercados menos competitivos. Porém, as evidências da presente 
pesquisa devem ser analisadas com cautela, já que os resultados não se mantiveram estáveis quando foram utilizadas diferentes aproximações para o desempenho da firma e diferentes aproximações de competição no mercado de produtos.

Tabela 21 - Efeito marginal da qualidade de governança corporativa sobre o desempenho: regressões utilizando o método de Efeitos Fixos para o período de 2005 a 2007 e critério dos tercis para separação dos setores

\begin{tabular}{|c|c|c|c|c|c|c|c|c|}
\hline Modelo & $\begin{array}{l}\text { Variável de } \\
\text { competição }\end{array}$ & $\begin{array}{l}\text { Alta/Baixa } \\
\text { competição }\end{array}$ & $\begin{array}{c}\text { Efeito } \\
\text { marginal }\end{array}$ & $\begin{array}{l}\text { Erro-padrão do } \\
\text { efeito marginal }\end{array}$ & Estatística-t & $\mathbf{P}>[\mathbf{t}]$ & \multicolumn{2}{|c|}{$\begin{array}{c}\text { Intervalo de confiança } \\
95 \%\end{array}$} \\
\hline \multicolumn{9}{|c|}{ Painel A: Lucro operacional próprio sobre o ativo total (EBIT_AT) } \\
\hline \multirow{2}{*}{ (i) } & \multirow{2}{*}{ HHI_4 } & Alta competição & 0.0037 & 0.0138 & 0.2707 & 0.7871 & -0.0236 & 0.0311 \\
\hline & & Baixa competição & $0.0381 * *$ & 0.0164 & 2.3320 & 0.0213 & 0.0058 & 0.0705 \\
\hline \multirow{2}{*}{ (ii) } & \multirow{2}{*}{ HHI_3 } & Alta competição & 0.0157 & 0.0173 & 0.9068 & 0.3662 & -0.0186 & 0.0500 \\
\hline & & Baixa competição & 0.0262 & 0.0292 & 0.8966 & 0.3717 & -0.0316 & 0.0839 \\
\hline \multirow{2}{*}{ (iii) } & \multirow{2}{*}{ C4_3 } & Alta competição & -0.0020 & 0.0175 & -0.1128 & 0.9105 & -0.0368 & 0.0328 \\
\hline & & Baixa competição & 0.0109 & 0.0115 & 0.9405 & 0.3500 & -0.0121 & 0.0339 \\
\hline \multirow{2}{*}{ (iv) } & \multirow{2}{*}{ NCOMP_4 } & Alta competição & 0.0036 & 0.0091 & 0.4010 & 0.6890 & -0.0143 & 0.0216 \\
\hline & & Baixa competição & $0.0196 * *$ & 0.0083 & 2.3628 & 0.0195 & 0.0032 & 0.0360 \\
\hline \multirow{2}{*}{ (v) } & \multirow{2}{*}{ NCOMP_3 } & Alta competição & -0.0053 & 0.0114 & -0.4642 & 0.6433 & -0.0278 & 0.0172 \\
\hline & & Baixa competição & -0.0200 & 0.0529 & -0.3779 & 0.7061 & -0.1247 & 0.0847 \\
\hline \multicolumn{9}{|c|}{ Painel B: Geração bruta de caixa sobre o ativo total(EBITDA_AT) } \\
\hline \multirow{2}{*}{ (i) } & \multirow{2}{*}{ HHI_4 } & Alta competição & -0.0010 & 0.0148 & -0.0690 & 0.9451 & -0.0304 & 0.0283 \\
\hline & & Baixa competição & $0.0362 * *$ & 0.0165 & 2.1890 & 0.0305 & 0.0035 & 0.0690 \\
\hline \multirow{2}{*}{ (ii) } & \multirow{2}{*}{ HHI_3 } & Alta competição & 0.0120 & 0.0174 & 0.6853 & 0.4945 & -0.0226 & 0.0465 \\
\hline & & Baixa competição & 0.0260 & 0.0298 & 0.8745 & 0.3837 & -0.0329 & 0.0850 \\
\hline \multirow{2}{*}{ (iii) } & \multirow{2}{*}{ C4_3 } & Alta competição & -0.0093 & 0.1724 & -0.0537 & 0.9573 & -0.3530 & 0.3344 \\
\hline & & Baixa competição & 0.0070 & 0.1720 & 0.0408 & 0.9675 & -0.3359 & 0.3499 \\
\hline \multirow{2}{*}{ (iv) } & \multirow{2}{*}{ NCOMP_4 } & Alta competição & 0.0029 & 0.0094 & 0.3084 & 0.7582 & -0.0157 & 0.0215 \\
\hline & & Baixa competição & $0.0193 * *$ & 0.0087 & 2.2116 & 0.0286 & 0.0021 & 0.0366 \\
\hline \multirow{2}{*}{ (v) } & NCOMP 3 & Alta competição & -0.0080 & 0.0128 & -0.6234 & 0.5341 & -0.0334 & 0.0174 \\
\hline & NCUIVIr_J & Baixa competição & -0.0226 & 0.0524 & -0.4306 & 0.6675 & -0.1263 & 0.0811 \\
\hline & icro an & es de juros, impo & e renda & reciação e a & zação sol & eceita & quida $(\mathrm{EF}$ & REC) \\
\hline (i) & HHI 4 & Alta competição & 0.0069 & 0.0108 & 0.6332 & 0.5277 & -0.0146 & 0.0283 \\
\hline (1) & HНI_4 & Baixa competição & 0.0161 & 0.0135 & 1.1906 & 0.2361 & -0.0107 & 0.0429 \\
\hline (ii) & HHI 3 & Alta competição & 0.0149 & 0.0532 & 0.2804 & 0.7796 & -0.0904 & 0.1202 \\
\hline (II) & HHI_3 & Baixa competição & 0.0305 & 0.0742 & 0.4112 & 0.6816 & -0.1164 & 0.1774 \\
\hline (iii) & $C 4$ & Alta competição & 0.0492 & 0.1695 & 0.2904 & 0.7723 & -0.2885 & 0.3869 \\
\hline (111) & C4_3 & Baixa competição & 0.1208 & 0.2073 & 0.5828 & 0.5618 & -0.2923 & 0.5339 \\
\hline (iv) & $\mathrm{NCOM}$ & Alta competição & -0.0060 & 0.0091 & -0.6531 & 0.5147 & -0.0240 & 0.0121 \\
\hline (IV) & NCUMIP_4 & Baixa competição & 0.0084 & 0.1035 & 0.0809 & 0.9357 & -0.1963 & 0.2131 \\
\hline (v) & NCOMP 3 & Alta competição & -0.0231 & 0.0372 & -0.6215 & 0.5354 & -0.0968 & 0.0505 \\
\hline & & Baixa competição & 0.1120 & 0.1407 & 0.7957 & 0.4277 & -0.1664 & 0.3904 \\
\hline & & & Painel D: $\mathrm{C}$ & de Tobin (TOBI & NSQ) & & & \\
\hline (i) & $\mathrm{HHI}$ & Alta competição & -1.0914 & 0.9956 & -1.0963 & 0.2751 & -3.0622 & 0.8793 \\
\hline (1) & HHI_4 & Baixa competição & -0.7420 & 0.9209 & -0.8058 & 0.4219 & -2.5648 & 1.0808 \\
\hline (ii) & HHT 3 & Alta competição & -0.5914 & 0.7176 & -0.8241 & 0.4117 & -2.0133 & 0.8305 \\
\hline (11) & HHI_3 & Baixa competição & -1.1827 & 1.7264 & -0.6851 & 0.4947 & -4.6034 & 2.2379 \\
\hline (iii) & $C_{4} 3$ & Alta competição & 0.1043 & 0.2049 & 0.5092 & 0.6123 & -0.3046 & 0.5132 \\
\hline (III) & C4_3 & Baixa competição & 0.8780 & 0.6180 & 1.4207 & 0.1600 & -0.3556 & 2.1116 \\
\hline (iv) & NCOMP 4 & Alta competição & -0.6842 & 0.6938 & -0.9861 & 0.3258 & -2.0559 & 0.6876 \\
\hline (iv) & NCOMP_4 & Baixa competição & $-0.5611 *$ & 0.3022 & -1.8571 & 0.0654 & -1.1585 & 0.0362 \\
\hline (y) & NCOMP 3 & Alta competição & -0.4219 & 0.3625 & -1.1641 & 0.2466 & -1.1393 & 0.2955 \\
\hline (v) & NCUMP_3 & Baixa competição & -0.3943 & 1.1903 & -0.3313 & 0.7410 & -2.7502 & 1.9616 \\
\hline
\end{tabular}


Por fim, como testes adicionais, são reportados os efeitos marginais da qualidade de governança corporativa quando outros critérios de separação ente setores mais e menos competitivos são utilizados. Especificamente, adotaram-se os intervalos para o HHI do DOJ, e o "ponto de corte" de 75\% definido pelo CADE. Os resultados estão reportados na Tabela 22.

As Tabelas 9-A até 11-A servem de base para as informações da Tabela 22.

Tabela 22 - Efeito marginal da qualidade de governança corporativa sobre o desempenho: regressões utilizando o método de Efeitos Fixos para o período de 2005 a 2007 e critérios do DOJ e CADE

\begin{tabular}{|c|c|c|c|c|c|c|c|c|}
\hline Modelo & $\begin{array}{c}\text { Variável de } \\
\text { desempenho }\end{array}$ & $\begin{array}{l}\text { Alta/Baixa } \\
\text { competição }\end{array}$ & $\begin{array}{c}\text { Efeito } \\
\text { marginal }\end{array}$ & $\begin{array}{l}\text { Erro-padrão do } \\
\text { efeito marginal }\end{array}$ & Estatística-t & $\mathbf{P}>[\mathbf{t}]$ & \multicolumn{2}{|c|}{$\begin{array}{c}\text { Intervalo de confiança } \\
95 \%\end{array}$} \\
\hline \multicolumn{9}{|c|}{ Painel A: Critério de separação entre mercados concentrados e não concentrados adotado pelo DOJ (HHI_4) } \\
\hline \multirow{2}{*}{ (i) } & \multirow{2}{*}{ EBIT_AT } & Alta competição & -0.0045 & 0.0099 & -0.4569 & 0.6484 & -0.0240 & 0.0150 \\
\hline & & Baixa competição & $0.0320 * *$ & 0.0160 & 2.0025 & 0.0470 & 0.0004 & 0.0635 \\
\hline \multirow{2}{*}{ (ii) } & \multirow{2}{*}{ EBITDA_AT } & Alta competição & -0.0057 & 0.0106 & -0.5372 & 0.5919 & -0.0265 & 0.0152 \\
\hline & & Baixa competição & $0.0335^{* *}$ & 0.0161 & 2.0824 & 0.0390 & 0.0017 & 0.0652 \\
\hline \multirow{2}{*}{ (iii) } & \multirow{2}{*}{ EBITDA_REC } & Alta competição & -0.0266 & 0.0363 & -0.7311 & 0.4658 & -0.0984 & 0.0452 \\
\hline & & Baixa competição & 0.0804 & 0.0784 & 1.0248 & 0.3070 & -0.0745 & 0.2353 \\
\hline \multirow{2}{*}{ (iv) } & \multirow{2}{*}{ TOBINSQ } & Alta competição & -0.7208 & 0.7330 & -0.9835 & 0.3270 & -2.1695 & 0.7278 \\
\hline & & Baixa competição & -0.3347 & 0.6671 & -0.5016 & 0.6167 & -1.6531 & 0.9838 \\
\hline \multicolumn{9}{|c|}{ Painel B: Critério de separação entre mercados concentrados e não concentrados adotado pelo DOJ (HHI_3) } \\
\hline \multirow{2}{*}{ (i) } & \multirow{2}{*}{ EBIT_AT } & Alta competição & 0.0017 & 0.0087 & 0.1905 & 0.8491 & -0.0155 & 0.0188 \\
\hline & & Baixa competição & 0.0233 & 0.0194 & 1.2033 & 0.2304 & -0.0149 & 0.0616 \\
\hline \multirow{2}{*}{ (ii) } & \multirow{2}{*}{ EBITDA_AT } & Alta competição & -0.0009 & 0.0088 & -0.1046 & 0.9168 & -0.0183 & 0.0165 \\
\hline & & Baixa competição & 0.0227 & 0.0191 & 1.1906 & 0.2354 & -0.0149 & 0.0604 \\
\hline \multirow{2}{*}{ (iii) } & \multirow{2}{*}{ EBITDA_REC } & Alta competição & 0.0068 & 0.0096 & 0.7079 & 0.4799 & -0.0122 & 0.0258 \\
\hline & & Baixa competição & 0.0217 & 0.0276 & 0.7884 & 0.4315 & -0.0327 & 0.0762 \\
\hline \multirow{2}{*}{ (iv) } & \multirow{2}{*}{ TOBINSQ } & Alta competição & 0.0009 & 0.1022 & 0.0091 & 0.9928 & -0.2007 & 0.2026 \\
\hline & & Baixa competição & -0.0748 & 0.2299 & -0.3255 & 0.7452 & -0.5287 & 0.3791 \\
\hline \multicolumn{9}{|c|}{ Painel C: Critério de separação entre mercados concentrados e não concentrados adotado pelo CADE (C4_3) } \\
\hline \multirow{2}{*}{ (i) } & \multirow{2}{*}{ EBIT_AT } & Alta competição & -0.0002 & 0.0076 & -0.0241 & 0.9808 & -0.0151 & 0.0148 \\
\hline & & Baixa competição & 0.0072 & 0.0135 & 0.5296 & 0.5970 & -0.0195 & 0.0338 \\
\hline \multirow{2}{*}{ (ii) } & \multirow{2}{*}{ EBITDA_AT } & Alta competição & -0.0030 & 0.0077 & -0.3961 & 0.6925 & -0.0182 & 0.0121 \\
\hline & & Baixa competição & 0.0033 & 0.0181 & 0.1818 & 0.8559 & -0.0323 & 0.0389 \\
\hline \multirow{2}{*}{ (iii) } & \multirow{2}{*}{ EBITDA_REC } & Alta competição & 0.0160 & 0.0176 & 0.9084 & 0.3648 & -0.0187 & 0.0507 \\
\hline & & Baixa competição & $0.0366^{* *} *$ & 0.0185 & 1.9774 & 0.0494 & 0.0001 & 0.0731 \\
\hline \multirow{2}{*}{ (iv) } & \multirow{2}{*}{ TOBINSQ } & Alta competição & -0.0459 & 0.2327 & -0.1973 & 0.8438 & -0.5049 & 0.4131 \\
\hline & & Baixa competição & 3.2063 & 2.1376 & 1.5000 & 0.1353 & -1.0103 & 7.4230 \\
\hline
\end{tabular}

Os modelos i e ii do Painel A retornam resultados semelhantes aos obtidos na Tabela 22. Esses resultados indicam que o efeito da governança sobre desempenho é relevante apenas em setores mais concentrados, que, segundo o racional da pesquisa, apresentam baixa competição. No modelo iii do Painel C, a mesma conclusão é extraída. Nos três casos, os efeitos marginais positivos são significantes a $5 \%$. 
Nesse momento, é útil retomar a questão de pesquisa 2: O efeito da governança corporativa sobre o desempenho das companhias brasileiras com ações listadas na BM\&BOVESPA depende do grau de competição no mercado de produtos?

Em síntese, diversos modelos foram estimados tendo como variáveis termos de interação ente governança e competição. Grande parte não apresentou significância estatística. Entretanto, os modelos i e iv dos Painéis A e B e o modelo iv do Painel D da Tabela 21, os modelos i e ii do Painel A e o modelo iii do Painel C da Tabela 22 apresentaram significância estatística. A interpretação geral destes resultados é que a qualidade de governança corporativa afeta positiva e significantemente o desempenho das companhias quando elas operam em setores menos competitivos. Contudo, os resultados não foram sistematicamente mantidos. $\mathrm{Na}$ pesquisa, foram definidas quatro proxies para desempenho e diferentes formas de separar os setores em competitivos e menos competitivos, com base na literatura sobre o tema. Logo, apenas em alguns testes os resultados acima descritos foram encontrados. Em estudos internacionais similares, principalmente o de Ammann et al. (2010), os autores identificam esses resultados de forma sistemática. No caso da presente pesquisa, as conclusões não podem ser expressas de forma categórica, em função de os resultados não persistirem ao longo dos diversos testes, todavia é possível afirmar que a qualidade de governança corporativa provavelmente não beneficia todas as companhias de forma linear, haja vista que alguns resultados acima descritos assim o sugerem. Ademais, retomando os dados do Quadro 12, a questão da amostra pode influenciar os resultados. A amostra da pesquisa é substancialmente inferior à utilizada nos estudos internacionais analisados. Isso reduz substancialmente a possibilidade de significância estatística. 


\section{CONSIDERAÇÕES FINAIS}

O objetivo principal da pesquisa foi investigar o relacionamento ente competição no mercado de produtos e a qualidade de governança corporativa das firmas no mercado brasileiro. Em razão de limitações concernentes a base de dados, a análise se restringiu a companhias de capital aberto pertencentes às indústrias extrativas e de transformação, que compõem um total de doze setores econômicos quando utilizada a classificação do Economática. O trabalho foi dividido em duas partes inter-relacionadas. A primeira parte investigou se as variáveis de competição no mercado de produtos impactam de forma significativa a qualidade de governança corporativa das companhias. A segunda parte investigou se o efeito da qualidade de governança corporativa sobre o desempenho das companhias varia em função do grau de competição no mercado de produtos.

Em relação à primeira parte, avaliou-se inicialmente a viabilidade da implementação das métricas de competição, considerando a disponibilidade de dados. Optou-se pelo Índice de Herfindahl-Hirschman (HHI) como principal variável para estimar a competição no mercado de produtos. O HHI, apesar de ser objeto de diversas críticas, é amplamente utilizado como um dos meios para identificar o grau de competição em um setor. A idéia é que um aumento no HHI aumente a probabilidade de exercício do poder de mercado por parte das empresas. Além disso, a fim de testar a robustez dos resultados, foram utilizadas a razão de concentração das quatro principais companhias do mercado e o número de competidores. Os dados foram extraídos da PIA-Empresa do IGBE. A opção pela base de dados do IBGE se deve ao fato de a PIA-Empresa oferecer cálculos dos índices de forma mais precisa, pois esse tipo de pesquisa abarca um grande número empresas.

Como aproximação da qualidade de governança corporativa, na pesquisa foi empregado um índice amplo denominado Índice de Governança Corporativa (IGOV) utilizado pelo IBGC como aproximação para a qualidade de governança corporativa das companhias. Por meio deste índice, o referido Instituto premia anualmente as companhias abertas com as melhores práticas de governança corporativa. Além disso, em um teste de robustez, utilizou-se o IGOV elaborado por Leal e Carvalhal-da-Silva (2005), cuja disponibilidade vai de 1998 a 2004. 
As variáveis de controle foram definidas com base nos trabalhos de Black et al. (2009), Silveira et al. (2007), Brown e Caylor (2006), Durnev e Kim (2005), Silveira (2004), Leal e Carvalhal-da-Silva (2005), Klapper e Love (2002) e Gompers et al. (2003).

Inicialmente, foram empreendidas análise exploratórias: gráficos de dispersão, matrizes de correlações e testes de diferenças de média. Todos métodos simples, porém que ajudam o pesquisador a visualizar um possível relacionamento entre variáveis. Estas análises exploratórias evidenciaram que a competição no mercado de produtos se relaciona de forma negativa com a qualidade de governança corporativa das companhias. Isso significa que o aumento da competição no mercado de produtos tende a diminuir a qualidade de governança corporativa das companhias. No estudo de Chou et al. (2008) foram identificados resultados similares. Porém, a aplicação de técnicas econométricas relativamente mais complexas apresentou um resultado distinto do observado por essas técnicas mais simples. Estas análises indicam que quanto menor o grau de competição no mercado de produtos, menor a governança corporativa das companhias. Especificamente, as variáveis C4_3 e NCOMP_4, para os anos de 2005 e 2007, e a variável HHI_4, nos testes de robustez contemplando o período de 1998 a 2004. Em relação à literatura analisada, essa conclusão é próxima da obtida por Karuna (2008). Todavia, os resultados precisam ser analisados com cautela, visto que nem todas as variáveis de competição utilizadas na pesquisa apresentaram significância e, portanto, não é possível identificar com certeza o sentido desse relacionamento. De qualquer modo, o fato de algumas das variáveis de competição utilizadas nos modelo terem apresentado resultados estatisticamente significativos sugere que são potenciais determinantes da qualidade de governança corporativa e que podem ser empregadas em futuras pesquisas sobre o tema

Na segunda parte da pesquisa, avaliou-se se o efeito da qualidade de governança corporativa sobre o desempenho da companhia depende do grau de competição no mercado de produtos. Logo, tem-se uma hipótese condicional que necessita da inclusão de termos de interação no modelo empírico para que a resposta seja obtida. Nos trabalhos de Friedrich (1982), Hardy (1993), Kam e Franzese (2003) e Brambor et al. (2005) foram estudados os aspectos necessários para a correta interpretação e apresentação dos termos de interação utilizados nas regressões. 
Ao todo, foram empregadas quatro aproximações para o conceito de desempenho. A primeira, EBIT_AT, uma medida de retorno do investimento. A segunda, EBITDA_AT, uma medida da geração bruta de caixa. A terceira, EBITDA_REC, uma métrica de rentabilidade. E, por fim, a quarta, TOBINSQ, uma medida de valor. A utilização de quatro variáveis teve como objetivo precípuo avaliar a estabilidade dos resultados. Para classificar um setor em competitivo ou não competitivo, recorreu-se aos trabalhos de Kadyrzhanova e Rhodes-Kropf (2007), Giroud e Mueller (2008) e Ammann et al. (2010).

Em síntese, diversos modelos foram estimados tendo como variáveis termos de interação entre governança e competição. Grande parte não apresentou significância estatística. Entretanto, em algumas das especificações tendo como variáveis dependentes EBIT_AT, EBITDA_AT ou EBITDA-REC, foram observados efeitos marginais positivos de governança sobre o desempenho quando a empresa operava em um mercado de baixa competição. A interpretação geral destes resultados é que a qualidade de governança corporativa afeta positiva e significantemente o desempenho das companhias quando elas operam em setores menos competitivos. Contudo, os resultados não foram sistematicamente mantidos. Logo, apenas em alguns testes os resultados acima descritos foram encontrados. Em estudos internacionais similares, principalmente o de Ammann et al. (2010), os autores identificam esses resultados de forma sistemática. No caso da presente pesquisa, as conclusões não podem ser expressas de forma categórica, em função de os resultados não persistirem ao longo dos diversos testes, todavia é possível afirmar que a qualidade de governança corporativa provavelmente não beneficia todas as companhias de forma linear, haja vista que alguns resultados acima descritos assim o sugerem.

As principais limitações do trabalho forma apresentadas na seção 3.7. Em resumo, a amostra de empresas e o período de tempo estudado são a primeira limitação da pesquisa. Ademais, Barros et al. (2009) elencam três causas fundamentais de problemas de endogeneidade presentes em pesquisas empíricas, que também limitam os resultados desta pesquisa, a saber: variáveis omitidas, erros de mensuração dos regressores e simultaneidade (ou causalidade reversa). Todos esses pontos foram discutidos com detalhes na referida seção. Portanto, pesquisas futuras sobre o tema podem partir das limitações já apresentadas e, assim, elaborarem estratégias empíricas de forma a mitigá-las. 
Na subseção 2.4.12 foi apresentado um quadro com o sumário dos estudos mais importantes utilizados para o desenvolvimento desta pesquisa. Neste quadro, procurou-se dividir os diversos artigos em grandes categorias, a fim de estruturar, ainda que de forma incipiente, ma potencial agenda para futuras pesquisas no Brasil. A apreciação do citado quadro permite levantar uma série de questões que poderiam se beneficiar da inclusão de uma variável que servisse como proxy para competição no mercado de produtos. Como idéia inicial, poderia ser elaborada uma pesquisa sobre os benefícios privados do controle. No Brasil, em função da estrutura patrimonial de diversas companhias ser compostas por dois tipos de ações, ordinárias e preferenciais, que conferem diferentes espécies de direitos aos acionistas, há a possibilidade de se estudar o impacto da competição no mercado de produtos sobre a diferença de preços entre tais tipos. Ademais, estudos sobre o determinantes da divulgação de informações contábeis poderiam se valer dos trabalhos de Shin (2002) e Li (2010). Independência do Conselho de Adminstração, grau de incentivos oferecidos aos gestores, adoção de cláusulas antitakeover, e assim por diante. Outra fonte de interessantes conclusões seria realizar um experimento "natural" sobre os efeitos do aumento de competição após a promulgação de leis ou desregulamentação de setores. Os trabalhos de Kole e Lehn (1999), Rennie (2006) e Karuna (2008) são bons pontos de partida para pesquisadores interessados no tema.

Além das oportunidades de pesquisa apresentadas dentro da temática governança corporativa, outras linhas de pesquisa podem se valer da consideração explícita da competição no mercado de produtos para explicar alguns fenômenos. Exemplos de estudos que já a consideram, são os seguintes: decisões sobre estrutura de capital (CHEVALIER, 1995); utilização de variáveis não financeiras para a tomada de decisão (IBRAHIM et al., 2001); estudos sobre responsabilidade social corporativa (FERNÁNDEZ-KRANZ; SANTALÓ, 2008); retorno das ações (HOU; ROBINSON, 2006); conservadorismo contábil (DHALIWAL et al, 2008) decisão de a empresa listar suas ações em bolsa (CHEMMANUR; HE, 2009), e ocorrência de insider trading no mercado de capitais (PERESS, 2008).

Com relação às contribuições pesquisa, em relação ao arcabouço teórico da área, os resultados da pesquisa podem contribuir com a literatura nacional sobre governança corporativa ao considerar os atributos do mercado no qual a firma opera e os impactos provenientes desses 
atributos. Internacionalmente, a pesquisa constitui-se em mais uma evidência das relações entre competição, governança corporativa e desempenho, todavia aplicada a outro contexto jurídico e econômico. Assim, poderá servir de comparação para outros estudos. Do ponto de vista dos pesquisadores da área, a pesquisa contribui com uma nova variável a afetar a definição da estrutura de governança das companhias e, assim, ser utilizadas em modelos estatísticos: competição. Portanto, novas pesquisas podem incorporar e aperfeiçoar esse desenvolvimento, na medida em que outras métricas podem ser utilizadas para representar o nível de competição de setores. Por fim, a pesquisa potencialmente contribui com os reguladores de assuntos relacionados à governança corporativa, pois ao considerar diversas evidências de que o grau de competição em setores tende a influenciar a estrutura de governança corporativa das companhias, os reguladores poderiam estabelecer recomendações de governança de acordo a estrutura de cada setor.

Como síntese da dissertação, expõe-se que propor metodologias para considerar o efeito explícito da competição no mercado de produtos em modelos empíricos tem o potencial de gerar resultados interessantes, pois a teoria e resultados empíricos pesquisados evidenciam que a variável competição exerce influência sobre grande parte das decisões tomada pelos agentes internos à empresa. 


\section{REFERÊNCIAS}

ADEOYE, Adewale. Macro-economic Level Corporate Governance and FDI in Emerging Markets: Is there a Close Relationship. Londres, 2007. Dissertação (Mestrado em International Management). Mangement Department of School of Social Science and Public Policy, King's College London.

AGHION, Philippe et al. Financial Discipline and Growth. The Review of Economic Studies, v. 66, n. 4, p. 825-852, October, 1999.

AHN, S. Competition, Innovation and Productivity Growth: A Review of Theory and Evidence. OECD Economics Department Working Papers, n. 317, 2002.

ALCHIAN, Armen A. Uncertainly, Evolution, and Economic Theory. The Journal of Political Economy, v. 58, n. 3, p. 211-221, June, 1950.

ALENCAR, Roberta Carvalho; LOPES, Alexsandro Broedel. Disclosure and cost of equity capital in emerging markets: the Brazilian case. In: ENCONTRO BRASILEIRO DE FINANÇAS - EBFIN, 8, 2008, Rio de Janeiro: SBFIN, 2008.

ALI, Ashiq et al. The limitations of Industry Concentration Measures Constructed with Compustat Data: Implications for Finance Research. Fevereiro de 2008. Disponível em:< http://papers.ssrn.com/sol3/papers.cfm?abstract id=926269>. Acesso em: 12/10/2009.

ALLEN, Franklin; GALE, Douglas. Corporate Governance and Competition. Financial Institutions Center, n. 99-28, 1999. Disponível em: < http://fic.wharton.upenn.edu/fic/papers/99/9928.pdf>. Acesso em: 12/12/2008.

AMMANN, Manuel et al. Product Market Competition, Corporate Governance, and Firm Value: Evidence from the EU-Area. In: 2010 FMA EUROPEANCONFERENCE, 2010, Hamburg. Disponível em: < http://www.fma.org/Hamburg/HamburgProgram.htm>. Acesso em: 19/06/2010.

BAGGS, Jen; BETTIGNIES, Jean-Etienne de. Product Market Competition and Agency Costs. Sauder School of Business Working Paper. 2006. Disponível em: <http://papers.ssrn.com/sol3/papers.cfm?abstract id=604821>. Acesso em: 02/11/2009.

BAI, Chong-En et al. Corporate Governance and Firm Valuations in China. Julho de 2003. Disponível em: < http://papers.ssrn.com/sol3/papers.cfm?abstract_id=361660>. Acesso em: 02/11/2009.

BAKER, Jonathan B.; BRESNAHAN, Timothy. Economics Evidence in Antitrust: Defining Markets and Measuring Market Power. Stanford Law and Economics Olin Working Paper No. 328. Disponível em: < http://papers.ssrn.com/sol3/papers.cfm?abstract id=931225>. Acesso em: 02/11/2009. 
BARBER, Brad; LYON, John. Detecting abnormal operating performance: the empirical power and specification of test statistics. Journal of Financial Economics, v. 41, p. 359-400, 1996.

BARROS, Lucas A. B. C. Decisões de Financiamento e de Investimento das Empresas sob a ótica de gestores otimistas e excessivamente confiantes. São Paulo, 2004. Tese (Doutorado em Administração) - Programa de Pós-Graduação em Administração, Faculdade de Economia, Administração e Contabilidade da Universidade de São Paulo

BARROS, Lucas A. B. C. et al. Métodos de investigação empírica com dados observacionais em finanças corporativas. Relatório Técnico para o CNPQ, projeto número 401562/2006-9, 2009.

BEBCHUK, Lucian. Why firms adopt antitakeover arrangements. University of Pennsylvania Law Review, v. 152, p. 713-753, 2003. Disponível em <http://papers.ssrn.com/sol3/papers.cfm?abstract_id=404200>. Acesso em: 02/11/2009.

BEBCHUK, Lucian et al. What matters in corporate governance? Harvard Law School John M. Olin Center Discussion Paper N.. 491, 2004. Disponível em <http://ssrn.com/abstract=593423 $>$. Acesso em: 28/09/2009.

BECHT, Marco et al.Corporate governance and control. ECGI Finance Working Paper n. 02/2002, 2002. Disponível em <http://ssrn.com/abstract id=343461>. Acesso em: $15 / 10 / 2009$.

BEINER, Stefan et al. An Integrated Framework of Corporate Governance and Firm Valuation - Evidence from Switzerland. ECGI - Finance Working Paper No. 34/2004. Disponível em: < http://papers.ssrn.com/sol3/papers.cfm?abstract_id=489322>. Acesso em: 02/11/2009.

BEINER, Stefan et al. Product Market Competition, Mangerial Incentives, and Firm Valuation. $\quad$ February, $2009 . \quad$ Disponível em <http://papers.ssrn.com/sol3/papers.cfm?abstract_id=645562>. Acesso em: 15/10/2009.

BESANKO, David et al. A Economia da Estratégia. 3 ed. Porto Alegre: Bookman, 2006.

BHAGAT, Sanjai, JEFFERIS, Richard. The Econometrics of Corporate Governance Studies. 1st ed. Massachusetts Institute of Technology, 2002.

BHAGAT, Sanjai; BOLTON, Brian; ROMANO, Roberta. The promise and peril of corporate governance indices. Law Working Paper $\mathbf{N}^{\mathbf{0}}$ 89/2007, 2007. Disponível em <http://papers.ssrn.com/sol3/papers.cfm?abstract_id=1019921>. Acesso em: 05/06/2009.

BHOJRAJ, Sanjeev et al. What's My Line? A Comparison of Industry Classification Schemes for Capital Market Research. Johnson Graduate School of Management Cornell University, Ithaca, NY 14853, 19/05/2003. Disponível em < http://papers.ssrn.com/sol3/papers.cfm?abstract_id=356840>. Acesso em: 28/04/2010. 
BLACK, Bernard. The corporate governance behavior and market value of Russian firms. Emerging Markets Review, v. 2, p. 89-108, 2001.

BLACK, Bernard et al. Does corporate governance predict firms' market values? Evidence from Korea. Journal of Law, Economics, and Organization, v. 22, n. 2, Fall, 2006. Disponível em <http://ssrn.com/abstract=311275>. Acesso em: 02/11/2009.

BLACK, Bernard S. et al. Does one size fit all in corporate governance? Evidence from Brazil. Northwestern Law \& Economics Research Paper No. 09-20, 2009. Disponível em $\langle$ http://ssrn.com/abstract=1434116>. Acesso em: 15/10/2009.

BØHREN, Øyvind, ØDEGAARD, Bernt Arne. Governance and performance revisited. ECGI finance working paper, n. 28/2003, September, 2003. Disponível em < http://ssrn.com/abstract id=423461>. Acesso em: 15/10/2009.

BOONE, Jan. A new way to measure competition. Tilburg University Discussion Paper, 2004/31, 2004. Disponível em: < http://arno.uvt.nl/show.cgi?fid=10537>. Acesso em: $12 / 10 / 2009$.

BOONE, Jan; VAN DIJK, Theon. Competition and Innovation. De Economist, n. 03, 1998. Disponível em: < http://www.springerlink.com/content/qxp5850472t0680t/>. Acesso em: $15 / 05 / 2010$.

BOONE, Jan et al. Measuring competition. Advanced Institute of Mangement Research Working paper series, 22/2005, 2005. Disponível em < http://papers.ssrn.com/sol3/papers.cfm?abstract id=1307004>. Acesso em: 15/09/2009.

BOONE, Jan et al. How (not) to measure competition. Tilec Discussion Paper, 14/2007, 2007. Disponível em: < http://www.cpb.nl/eng/pub/cpbreeksen/discussie/91/disc91.pdf>

Acesso em: 12/10/2009.

BÖRSCH-SUPAN, Axel; KÖKE, Jens. An applied econometricians' view of empirical corporate governance studies. Abril de 2000. Disponível em: $<$ http://ssrn.com/abstract=373383. . . Acesso em: 10/11/2008.

BOZEC, Richard. Boards of Directors, Market Discipline and Firm Performance. Journal of Business Finance \& Accounting, v. 32, n.9-10, p. 1921-1960, 2005.

BRAGA, Helson C.; MASCOLO, João L. Mensuração da Concentração Industrial no Brasil. Pesquisa e Planejamento Econômico, vol. 12, nº 02, p. 399-454, ago, 1982.

BRAMBOR, Thomas et al. Understanding Interaction Models: improving empirical analyses. Political Analysis, v. 14, n. 1, p. 63-82, 2006.

BROWN, Lawrence D.; CAYLOR, Marcus L. Corporate governance and firm valuation. Journal of Accounting and Public Policy, v. 25, p. 409-434, 2006.

CAMERON, A. Colin; TRIVEDI, Pravin K. Microeconometrics using stata. Texas: Stata Press, 2009. 
CARLTON, Dennis W.; PERLOFF, Jeffrey. Modern Industrial Organization. 3rd ed. Reading, Mass: Addison-Wesley, 2000.

CASTRO, Cláudio de Moura. A prática da pesquisa. São Paulo: McGraw-Hill, 1978.

CHANCELLOR, Edward. Salve-se quem puder: uma história de especulação financeira. São Paulo: Companhia das Letras, 2001.

CHEMMANUR, Thomas J.; HE, Jie. IPO Waves, Product Market Competition, and the Going Public Decision: Theory and Evidence. Janeiro de 2009. Disponível em: <http://papers.ssrn.com/sol3/papers.cfm?abstract id=1270985>. Acesso em: 02/11/2009.

CHEVALIER, Judith A. Capital Structure and Product Market Competition: Empirical Evidence from the Supermarket Industry. The American Economic Review, v. 85, n. 3, p. 415-435, June, 1995.

CHHAOCHHARIA, Vidhi et al. Product Market Competition and Agency Conflicts: Evidence from the Sarbanes Oxley Law. March, 2009. Disponível em < http://papers.ssrn.com/sol3/papers.cfm?abstract_id=1109225>. Acesso em: 15/10/2009.

CHOU, Wen-Hsiu et al. Product Market Competition and Corporate Governance. Research Seminar Series of University of Wisconsin, 2008.

CHUNG, Kee; PRUITT, Stephen. A simple approximation of Tobin'Q. Financial Management, v. 23, n. 3, p. 70-74, Autumn, 1994.

CLAESSENS, Stijn. Corporate Governance and Development. Focus 1. Global Corporate Governance $\quad$ Forum, $2003 . \quad$ Disponível em: http://www.ifc.org/ifcext/cgf.nsf/AttachmentsByTitle/Focus_1_CG_and_Development/\$FILE /Focus_1_Corp_Governance_and_Development.pdf. Acesso em: 12/10/2009.

CLARKE, Richard N. SIC as Delineators of Economic Markets. The Journal of Business, v. 62, n. 1, p. 17-31, January, 1989.

COFFEE, J. The Future as History: The prospects for Global convergence in Corporate Governance and its implications. Northwestern University Law Review, 93, p. 641-708, 1999. Disponível em: < http://papers.ssrn.com/sol3/papers.cfm?abstract_id=142833>. Acesso em: 12/10/2009;

COLES, Jeffrey L; DANIEL, Naveen D.; NAVEEN, Lalitha. Boards: Does one size fits all? Disponível em < http://papers.ssrn.com/sol3/papers.cfm?abstract_id=665746>. Acesso em: 02/11/2009.

COMISSÃO NACIONAL DE CLASSIFICAÇÕES. Introdução à Classificação Nacional de Atividades Econômicas - CNAE versão 2.0. 2007.

CONWAY, Paul et al. Product Market Regulation in OECD Countries: 1998 to 2003. OECD Economics Department Working Papers, n. 419, 2005, OECD Publishing. 
CREMERS, K. J. Martins et al. Takeover Defenses and Competition: The Role of Stakeholders. Journal of Empirical Legal Studies, v. 5, n. 4, p. 791-818, December, 2008.

CUBBIN, John S. Market structure and performance: the empirical research. New York: Harwood, 1988.

CUÑAT, Vicente; GUADALUPE, Maria. Executive Compensation and Product Market Competition. CEPDP, 617. Centre for Economic Performance, London School of Economics and Political Science, London, UK, 2004. Disponível em < http://eprints.lse.ac.uk/19985/>. Acesso em: 28/04/2010.

CUÑAT, Vicente; GUADALUPE, Maria. How does product market competition shape incentive contracts? CEPDP, 687. Centre for Economic Performance, London School of Economics and Political Science, London, UK, 2005 Disponível em < http://cep.lse.ac.uk/pubs/download/dp0687.pdf>. Acesso em: 28/04/2010.

CURRY, B.; GEORGE, K. D. Industrial concentration: a survey. The Journal of Industrial Economics, v. 31, n. 3, p. 203-255, March, 1983.

DAVIES, Stephen et al. Economics of Industrial Organisation. London : Longman, 1989.

DEANGELO, Harry et al. Dividend Policy, Agency Costs, and Earned Equity. Junho de 2004. Disponível em: < http://papers.ssrn.com/sol3/papers.cfm?abstract_id=442740>. Acesso em: 19/06/2010.

DEFOND, Mark L.; PARK, Chul W. The effect of competition on CEO turnover. Journal of Accounting and Economics, vol. 27, n. 1, p. 35-56, February, 1999.

DEMSETZ, Harold. Industry Structure, Market Rivalry, and Public Policy. Journal of Law and Economics, v. 16, n.1, p. 1-9, April, 1973.

DHALIWAL, Dan et al. Product Market Competition and Accounting Conversatism. Dezembro de 2008. Disponível em: <http://papers.ssrn.com/sol3/papers.cfm?abstract_id=1266754>. Acesso em: 02/11/2009.

DOBIJA, Dorota. 2008. Emergence of Corporate Contract Set, Governance and Accountability: Standing Orders of the East India Company, 1600-1621. Disponível em $<$ http://ssrn.com/abstract=1159928 $>$. Acesso em: 12/10/2009.

DONSIMONI, Marie-Paule et al. Concentration Indices and Market Power. The Journal of Industrial Economics, vol. 32, nº 4, p. 419-434, June, 1984.

DRUKKER, David M. Testing for serial correlation in linear panel-data models. The Stata Journal, v.3, n.2, p. 168-177, 2003.

DYCK, Alexander; ZINGALES, Luigi. The corporate governance role of the media, The Right to Tell: The Role of Media in Development. New York: Oxford University Press, 2002. 
DYCK, Alexander, ZINGALES, Luigi. Private benefits of control: an international comparison. Journal of Finance. v. 59, p. 537-600. 2004.

DURNEV, Art, KIM, Han. To steal or not to steal: firm attributes, legal environment, and valuation. Journal of Finance, v. 60, n. 3, p. 1461-1493, June, 2005.

FAMA, Eugene. Agency problems and the theory of the firm. Journal of Political Economy, v. 88, n. 2, p.288-307, 1980.

FÁVERO, Luiz Paulo et al. Análise de dados: modelagem multivariada para tomada de decisões. Rio de Janeiro: Elsevier, 2009.

FEE, C. Edward; HADLOCK, Charles J. Mangement turnover and product market competition: empirical evidence from the US Newspaper Industry. The Journal of Business, v. 73, n.2, p. 205-243, April, 2000.

FEIJO, Carmem Aparecida; CARVALHO, Paulo Gonzaga M.; RODRIGUEZ, Maristella Shaefers. In: ENCONTRO NACIONAL DE ECONOMIA ANPEC, XXIX, 2001, Salvador. Anais do XXIX Encontro Nacional de Economia. Salvador: ANPEC, 2001.

FERGUSON, Paul R. Industrial economics: issues and perspectives. Houndmills: Macmillan, 1992.

FERGUSON, Paul R.; FERGUSON, Glenys J. Industrial Economics: issues and perspectives. $2^{\text {nd }}$ ed. Basingstoke: Macmillan, 1994.

FERNÁNDEZ-KRANZ, Daniel; SANTALÓ, Juan. When necessity becomes a virtue: the effect of product market competition on corporate social responsibility. IE Business School Working Paper. WP08-27, 16/07/2008. Disponível em < http://papers.ssrn.com/sol3/papers.cfm?abstract id=1608075>. Acesso em: 28/04/2010.

FIELD, Andy. Descobrindo a estatística usando SPSS. 2 ed. Porto Alegre: Artmed, 2009.

FONTENELE, Ana Maria de Carvalho. Progresso e método na história das teorias da organização industrial. São Paulo, 1995. Tese (Doutorado em Economia) - Programa de PósGraduação em Economia, Faculdade de Economia, Administração e Contabilidade da Universidade de São Paulo.

FRIEDRICH, Robert J. In Defense of Multiplicative Terms in Multiple Regression Equations. American Journal of Political Science, v. 26, n. 4, p. 797-833, 1982.

FULGHIERI, Paolo; SUOMINEN, Matti. Does Bad Corporate Governance Lead To Too Little Competition? Corporate governance, capital structure, and industry concentration. European Corporate Governance Institute. Finance Working, $n^{\mathbf{o}} 74 / 2005$. Disponível em <http://papers.ssrn.com/sol3/papers.cfm?abstract id=442740>. Acesso em: 20/01/2009.

GEROSKY, P. Competition Policy and the Structure-Performance Paradigm. In: DAVIES, Stephen; LYONS, Bruce. Economics of industrial organization. London : Longman, 1989. 
GILLAN, Stuart L. Recent Developments in Corporate Governance: An Overview. Journal of Corporate Finance, v. 12, p. 381-402, 2006.

GILLAN, Stuart et al. Tradeoffs in corporate governance: evidence from board structures and charter provisions. Junho, 2006. Disponível em <http://papers.ssrn.com/sol3/papers.cfm?abstract_id=917544>. Acesso em: 17/10/2009.

GILLAN, Stuart L.; HARTZELL, Jay C.; STARKS, Laura T. Explaining corporate governance: board, bylaws, and charter provisions.

GIROUD, Xavier; MUELLER, Holger M. Corporate Governance, Product Market Competition, and Equity Prices. European Corporate Governance Institute, Finance Working, Paper $\mathrm{n}^{\mathrm{o}}$ 219/2008, 2008. Disponível em: < http://papers.ssrn.com/sol3/papers.cfm?abstract id=1247715>. Acesso em: 10/01/2009.

GIROUD, Xavier, MUELLER, Holger M. Does Corporate Governance Matter in Competitive Industries? New York University Working Paper, FIN-07-021, 2009. Disponível em: <http://papers.ssrn.com/sol3/papers.cfm?abstract_id=1293603〉. Acesso em: $15 / 10 / 2009$.

GOERGEN, Marc et al. Corporate governance convergence: evidence from takeover regulation. European Corporate Governance Institute, Law Woking Paper, 33/2005, 2005. Disponível em <http://papers.ssrn.com/sol3/papers.cfm?abstract id=709023>. Acesso em: 02/11/2009.

GOMPERS, Paul A. et al. Corporate Governance and Equity Prices. Quartely Journal of Economics, v. 118, n. 1, p. 107-155, February, 2003.

GORGA, Érica. Changing the Paradigm of Stock Ownership: From Concentrated Towards Dispersed Ownership? Evidence from Brazil and Consequences for Emerging Countries. 3rd Annual Conference on Empirical Legal Studies Papers, abril de 2008. Disponível em:< http://papers.ssrn.com/sol3/papers.cfm?abstract id=1121037>. Acesso em: 12/10/2009.

GRIFFITH, Rachel. Product Market Competition, Efficiency and Agency Costs: an empirical analysis. The Institute for Fiscal Studies, WP01/12, June, 2001. Disponível em < http://www.ifs.org.uk/wps/wp0112.pdf>. Acesso em: 28/04/2010.

GROSFELD, Irena; TRESSEL, Thierry. Competition and Corporate Governance: Substitutes or Complements? Evidence from the Warsaw Stock Exchange. August, 2001. Disponível em <http://papers.ssrn.com/sol3/papers.cfm?abstract_id=268634>. Acesso em: 02/11/2009.

GRUllon, Gustavo; MICHAELY, Roni. Corporate Payout Policy and Product Market Competitio. 2006 Disponível em http://papers.ssrn.com/sol3/papers.cfm?abstract_id=972221>. Acesso em: 28/04/2010.

GUADALUPE, Maria; PÉRES-GONZÁLEZ, Francisco. The Impact of Product Market Competition on Private Benefits of Control. 2006. Disponível em < http://papers.ssrn.com/sol3/papers.cfm?abstract_id=890814>. Acesso em: 10/01/2009. 
HAIR, Joseph F. et al. Análise Multivariada de Dados. 5. ed. Porto Alegre: Bookman, 2005.

HARDY, Melissa A. Regression with dummy variables. Sage University Paper series on Quantitative Applications in the Social Sciences, 07-93. Newbury Park, CA: Sage, 1993.

HART, Oliver D. The Market Mechanism as an Incentive Scheme. The Bell Journal of Economics 14, no 2, p. 366-382, Autumn, 1983.

HART, Oliver D. Corporate Governance: Some Theory and Implications. The Economic Journal, v. 105, p. 678-689, May, 1995.

HERMALIN, Benjamin E. The Effects of Competition on Executive Behavior. The RAND Journal of Economics. v. 23, n. 3, p. 350-36, Outono de 1992.

HIMMELBERG, Charles et al. Understanding the determinants of managerial ownership and the link between ownership and performance. Journal of Financial Economics, v. 53, p. 353-384, 1999.

HOJ, Jens et al. Product Market Competition in the OECD Countries: taking stock and moving forward. OECD Economics Department Working Papers, n. 575, OECD publishing, 2007. Disponível em < ilibrary.org/content/workingpaper/108734233645>. Acesso em: 28/04/2010.

HOLLANDA FILHO, Sérgio Buarque de. Estrutura industrial no Brasil: concentração e diversificação. São Paulo, 1982 - Programa de Pós-Graduação em Economia, Faculdade de Economia, Administração e Contabilidade da Universidade de São Paulo.

HOU, Kewei; ROBINSON, David T. Industry Concentration and Average Stock Returns. Fevereiro de 2005.2 Disponível em: <http://papers.ssrn.com/sol3/papers.cfm?abstract id=479726>. Acesso em: 02/12/2009.

HSIAO, Cheng. Why Panel Data? IEPR Working Paper No. 05.33 Disponível em: < http://papers.ssrn.com/sol3/papers.cfm?abstract_id=820204\&rec $=1 \&$ srcabs=902657> $>$. Acesso em: 18/04/2010.

IBRAHIM, Yussoff Ibrahim et al. Competition, Non-Financial Measures and the Effectiveness of Management Control Systems. Analisis, v. 08, p. 53-68, 2001. Disponível em: < http://eprints.uum.edu.my/642/>. Acesso em: 28/04/2010.

INSTITUTO BRASILEIRO DE GEOGRAFIA E ESTATÍSTICA. Pesquisa Industrial Anual referente aos anos de 1998, 2000, 2002, 2004, 2005, 2006 e 2007.

INSTITUTO BRASILEIRO DE GOVERNANÇA CORPORATIVA - IBGC. Código de Melhores Práticas de Governança Corporativa, IBGC, 4ª edição, 2009.

JACQUEMIN, Alexis. The new industrial organization: market forces and strategic behavior. Oxford: Clarendon Press, 1987. 
JANUSZEWSKI, Silke I; KOKE, Jens; WINTER, Joachim K. Product market competition, corporate governance and firm performance: An empirical analysis for Germany. Julho de 2001. Disponível em: <http://papers.ssrn.com/sol3/papers.cfm?abstract id=278275.>. Acesso em: 10/01/2009.

JENSEN, Michael C. Agency costs of free cash flow, corporate finance and takeover. American Economic Review, v. 76, n. 2, p. 323-39, May, 1986.

JENSEN, Michael. Value Maximization, Stakeholder Theory, and the Corporate Objective Function. Journal of Applied Corporate Finance, v. 14, n. 3, p.8-21, Fall, 2001.

JENSEN, Michael; MECKLING, William. Theory of the firm: managerial behavior, agency costs and ownership structure. Journal of Financial Economics, v. 3, p. 305-360, October, 1976.

JOHNSON, Simon et al. Tunneling. American Economic Review. v. 40, p. 22-27, 2000.

KADYRZHANOVA, Dalida; RHODES-KROPF, Matthew. Concentrating on Governance. American Financial Association Annual Meeting, 2007. Chicago: AFA, 2007.

KAHLE, Kathleen M.; WALKING, Ralph A. The Impact of Industry Classifications on Financial Research. 28/05/1996. Disponível em: http://papers.ssrn.com/sol3/papers.cfm?abstract id=40169 > . Acesso em: 28/04/2010.

KAM, Cindy D.; FRANZESE JR.; Robert J. Modeling and Interpreting Interactive Hypotheses in Regression Analysis: a refresher and some practical advice. University of Michigan, 2003. Disponível em:< http://investigadores.cide.edu/aparicio/data/Kam\&Franzese_InterpretingInteractionsinRegress ions_05.pdf>. Acesso em: 05/06/2010.

KARUNA, Christo. Industry Product Market Competition and Managerial Incentives. Journal of Accounting and Economics. v. 43, p. 275-297, July, 2007.

KARUNA, Christo. Industry Product Market Competition and Corporate Governance. Junho de 2008. Disponível em: <http://papers.ssrn.com/sol3/papers.cfm?abstract_id=1004228>. Acesso em: 01/05/2009.

KARUNA, Christo. Discussion of "The impact of product market competition on the quantity and quality of voluntary disclosure." Review of Accounting Studies, DOI: 10.1007/s11142010-9135-2, 2010.

KEDIA, Simi. Estimating product market competition: Methodology and application. Journal of Banking \& Finance, v. 30, p. 875-894, 2006.

KERLINGER, Fred N. Metodologia da Pesquisa em Ciências Sociais. São Paulo: EPU, 1980. 
KLAPPER, Leora; LOVE, Inessa. Corporate governance, investor protection and performance in emerging markets. World Bank Policy Research Working Paper No. 2818, 2002.

KOKE, Jens; RENNEBOOG, Luc. Do corporate control and product market competition lead to stronger productivity growth? Evidence from market-oriented and blockholder-based governance regimes. European Corporate Governance Institute, Finance Working Paper $\mathrm{n}^{\circ} \quad 14 / 2003, \quad 2003 . \quad$ Disponível em: http://papers.ssrn.com/sol3/papers.cfm?abstract_id=389000>. Acesso em: 28/04/2010.

KOLE, Stacey; LEHN, Kenneth. Deregulation, the evolution of corporate governance structure, and survival. The American Economic Review, v. 87, n.2, p. 421-425, 1997.

KOLE, Stacey; LEHN, Kenneth. Deregulation and the adaptation of governance structure: the case of US airline industry. Journal of Financial Economics, v. 52, n. 1 p. 79-117, 1999.

KOTHARI, S. P.; WARNER, Jerold. Measuring long-horizon security price performance. Journal of Financial Economics, v. 43, p. 301-340, 1997.

KRAAKMAN, Reinier et al. The Anatomy of Corporate Law. Oxford University Press, 2004.

KUPFER, David. Padrões de competitividade. In: ENCONTRO NACIONAL DE ECONOMIA ANPEC, XX, 1992, Campos do Jordão. Anais do XX Encontro Nacional de Economia. Campos do Jordão: ANPEC, 1992.

KUPFER, David; HASENCLEVER. Lia (Org.). Economia Industrial. São Paulo: Campus, $200 \underline{2}$.

KWOKA Jr, John E. Does the choice on concentration measure really matter? The Journal of Industrial Economics, v. 29, n. 4, p. 445-453, June, 1981.

LEAL, Ricardo. P.; CARVALHAL-DA-SILVA, André L. Corporate governance and value, in Brazil (and in Chile), Inter-American Development Bank, Latin American Research Network, Research Network Working Paper \#R-514, 2005. Disponível em < http://www.iadb.org/res/pub_desc.cfm?pub_id=R-514>. Acesso em: 10/01/2009.

LI, Xi. The Impacts of Product Market Competition on the Quantity and Quality of Voluntary Disclosures. Review of Accounting Studies, 2010. Disponível em < http://www.springerlink.com/content/n728674315577102/>. Acesso em: 30/06/2010.

LI, Weian; NIU, Jianbo. Product Market Competition and corporate governance in China: complementary or substitute? In: International Federation of Scholarly Associations of Mangement - IFSAM. Berlim, Alemanha. Berlim: IFSAM, 2006.

LIMA, Gerlando Augusto Samapaio Franco. Nível de evidenciação x custo da dívida das empresas brasileiras. Revista de Contabilidade e Finanças, USP. v. 20, n. 49, p. 95-108, janeiro/abril 2009. 
MACHADO, Esmael Almeida et al. Endogenia entre as Variáveis de Estrutura-CondutaDesempenho: Estudo Empírico na Indústria de Laticínios do Brasil (1997-2006). In:

SEMINÁRIOS DE ADMINISTRAÇÃO - SEMEAD, XI, 2008, São Paulo. Anais do XI Seminário de Administração - SEMEAD. São Paulo: SEMEAD, 2008.

MAHER, Maria; ANDERSSON, Thomas. Corporate Governance: Effects on Firm Performance and Economic Growth. 2000 Disponível em < http://papers.ssrn.com/sol3/papers.cfm?abstract_id=218490>. Acesso em: 23/12/2009.

MARCONI, Marina de Andrade; LAKATOS, Eva Maria. Fundamentos de Metodologia Científica. 6. ed. São Paulo: Atlas, 2005.

MAYERS, Collin. Corporate governance, competition and performance. OECD Economics Department Working Papers, 164, 1996. Disponível em < http://lysander.sourceoecd.org/vl=4463421/cl=43/nw=1/rpsv/cgi-

bin/wppdf?file=5lgsjhvj868n.pdf $>$. Acesso em: 01/08/2009.

MENDES-DA-SILVA, Wesley; MORAES, Walter Fernando Araújo de. Estrutura de governança, performance e turnover de executivos: um estudo com indústrias brasileiras Alcance (UNIVALI), Biguaçu/Santa Catarina, Brasil, v. 11, n. 1, p. 31-47, 2004.

MENDONÇA, Elvino et al. Fusões e aquisições, concentração industrial e a eficiência técnica: evidências empíricas para a indústria de transformação brasileira. In: ENCONTRO NACIONAL DE ECONOMIA - ANPEC, XXXVI, 2008, Bahia. Anais do XXXVI Encontro Nacional de Economia. Bahia: ANPEC, 2008.

NALEBUFF, Barry; STIGLITZ, Joseph E. Information, competition, and markets. American Economic Association, v. 73, n. 2, p. 278-283, May, 1983.

NICKELL, Stephen. Competition and Corporate Performance. The Journal of Political Economy, v. 104, n. 4, p. 724-746, August, 1996.

NICKELL, Stephen et al. What makes firms perform well? European Economic Review, v. 41, p. 783-796, April, 1997.

NORMAN, George; LA MANNA, Manfredi (Org.). The New Industrial Economics: recent developments in industrial organization, oligopoly, and game theory. Aldershot, Hants, EnglandBrookfield, Vt., USA : E. Elgar Pub., 1992.

OCDE. Product Market Competition and Economic Performance. 2002. Disponível em: <http://www.oecd.org/dataoecd/55/34/2487682.pdf>. Acesso em: 28/04/2010.

PAREDES, Troy A. Corporate Governance and Economic Development. Regulation, v. 28. n. 1, p. 34-39. Spring, 2005.

PARRINO, Robert. CEO Turnover and Outside Succesion a Cross-Sectional Analysis. Journal of Financial Economics, v. 46, n. 2, p. 165-197, November, 1997. 
PATTANAYAK, Manoranaj. Corporate governance, product market competition and firm performance in India: an empirical inquiry. 2008. Disponível em < http://ssrn.com/abstract=1341838 >. Acesso em: 01/10/2009.

PERESS, Joel. Product Market Competition, Insider Trading and Stock Market Efficiency. Agosto de 2008. Disponível em: <http://papers.ssrn.com/sol3/papers.cfm?abstract_id=970690>. Acesso em: 02/11/2099.

PETERSEN, Mitchell A. Estimating standard errors in finance panel data sets: comparing approaches. Kellog Finance Department Working Paper n. 329 jan. 2005. Disponível em: $<$ http://papers.ssrn.com/sol3/papers.cfm?abstract_id=661481>. Acesso em: 01/07/2010.

PINDYCK, Robert S.; RUBINFELD, Daniel L. Econometria. Rio de Janeiro: Elsevier, 2004.

PORTER, Michael. A Vantagem competitiva das nações. 12 ed. Rio de Janeiro: Elsevier, 1990.

RAITH, Michael. Competition, Risk, and Managerial Incentives. American Economic Review, v. 93, n. 4, 1425-1436.

RAJAN, Raghuram; ZINGALES, Luigi. Salvando o Capitalismo dos Capitalistas. Rio de Janeiro: Campus, 2004.

RANDOY, Trond; JENSSEN, Jan Inge. Board independence and product market competition in Swedish firms. Corporate Governance: An International Review, v. 12, n. 3, p. 281-289, July, 2004.

RENNIE, Craig. Governance Structure Changes and Product Market Competition: Evidence from U.S. Electric Utility Deregulation. Journal of Business, v. 79, n. 4, p. 1989-2018, 2006.

RESENDE, M. Medidas de Concentração Industrial: Uma Resenha, Análise Econômica, março e setembro, 1994, p. 24-33.

RHOADES, Stephen A. The Herfindahl-Hirschman Index. Federal Reserve Bulletin, v. 79, n.3, p. 188-189, March, 1993. Disponível em< http://fraser.stlouisfed.org/publications/frb/page/33101/download/66351/33101_19901994.pdf>. Acesso em: 28/04/2010.

RUZZIER, Christian A. Product-Market Competition and Managerial Autonomy. Harvard Business School Working Paper 09-082, 2009. Disponível em: $\lfloor$ http://www.hbs.edu/research/pdf/09-082.pdf>. Acesso em: 02/11/2009.

SAITO, Richard; SILVEIRA, Alexandre Di Miceli. The Importance of Tag Along Rights and Identity of Controlling Shareholders for the Price Spreads Between Dual-Class Shares: The Brazilian Case. Março de 2007. Disponível em < http://ssrn.com/abstract=1033478>. Acesso em: 20/01/2009. 
SAITO, Richard. SILVEIRA, Alexandre Di Miceli da. Governança Corporativa: Custos de Agência e Estrutura de Propriedade. RAE. Revista de Administração de Empresas, v. 48, p. 79-85, 2008.

SAMPIERI, Roberto Hernández et al. Metodologia de Pesquisa. 3. ed. São Paulo: McGrawHill, 2006.

SCHAFFER, Mark E.; STILLMAN, Steve. XTOVERID: Stata module to calculate tests of overidentifying restrictions after xtreg, xtivreg, xtivreg2, xthtaylor. 2006. Disponível em: < http://ideas.repec.org/c/boc/bocode/s456779.html>. Acesso em 01/07/2010.

SCHARFSTEIN, David. Product market competition and managerial slack. The Rand Journal of Economics, v. 19, n. 1, p. 147-155, Spring, 1988.

SCHERER, Frederic M; ROSS, David. Industrial market structure and economic performance. Boston: Houghton Mifflin, 1990.

SCHIMIDT, Klaus. Managerial incentives and product market competition. Review of Economic Studies, vol. 64, n.2, p. 191-213, April, 1997.

SCHIMIDT, Cristiane Alkmin Junqueira; LIMA, Marcos André de. Índices de Concentração. Documento de trabalho SEAE/MF nº 13, 2002.

SCHMALENSEE, Richard. Handbook of industrial organization. In: SCHAMLENSEE, Richard; WILLING, Robert D. Amsterdam; New York : North-Holland: Sole distributors for the U.S.A. and Canada, Elsevier Science Pub. Co., 1989

SECRETARIA DE ACOMPANHAMENTO ECONÔMICO (SEAE) E SECRETARIA DE DIREITO ECONÔMICO (SDE). Portaria Conjunta $\mathbf{n}^{\circ}$ 50, Guia para Análise Econômica de Atos de Concentração Horizontal. 2001.

SHEPHERD, William G. The econômics of industrial organization. 3rd ed. Englewood Cliffs: Prentice-Hall, 1990.

SHIN, Yong-Chul. The Effect of Product Market Competition on Corporate Voluntary Disclosure Decisions. December, 2002. Disponível em < http://papers.ssrn.com/sol3/papers.cfm?abstract_id=338361>. Acesso em: 07/09/2009.

SHLEIFER, Andrei; VISHNY, Robert. A survey of corporate governance. Journal of Finance, v. 52, n.2, p.737-783, 1997.

SHY, Oz. Industrial Organization: theory and applications. Cambridge, Mass.: MIT Press, 1995.

SILVEIRA, Alexandre Di Miceli da. Governança corporativa e estrutura de propriedade: determinantes e relação com o desempenho das empresas no Brasil. São Paulo, 2004. Tese (Doutorado em Administração) - Programa de Pós-Graduação em Administração, Faculdade de Economia, Administração e Contabilidade da Universidade de São Paulo. 
SILVEIRA, Alexandre Di Miceli da. Governança corporativa: teoria e prática. Rio de Janeiro: Elsevier, 2010.

SILVEIRA, Alexandre Di Miceli da; BARROS, Lucas Ayres B. de C. Corporate Governance Quality and Firm Value in Brazil, 2007. Disponível em: 〈http://ssrn.com/abstract=923310〉. Acesso em: 28/09/2009.

SILVEIRA, A. M. et al. Endogeneity of Brazilian Corporate Governance Quality Determinants. Working paper, 2007. Aceito para publicação em Corporate Governance The International Journal of Business in Society.

STIGLER, George J. The Economics of Scale. Journal of Law and Economics, v. 1, p. 54$71,1958$.

TIROLE, Jean. Theory of Industrial Organization. Cambridge : The Mit Press, 1989.

TIROLE, Jean. The Theory of Corporate Finance. Princeton University Press, 2006.

U.S. DEPARTMENT OF JUSTICE AND THE FEDERAL TRADE COMMISSION. Horizontal Merger Guidelines. Abril, 1997.

WALDMAN, D.E; JENSEN, E.J. Industrial organization: Theory and practice, Reading: Addison-Wesley, 1998.

WILLIAMSON, Oliver. Corporate Governance. The Yale Law Journal, Vol. 93, No. 7, pp. 1197-1230, June, 1984.

WILlIAMSON, Oliver. Corporate Finance and Corporate Governance. The Journal of Finance. v. 43, n. 3, p. 567-591, July, 1988.

WINTOKI, M. Babajide et al. Endogeneity and the Dynamics of Corporate Governance, 2008. Disponível em < http://ssrn.com/abstract=970986>. Acesso em: 10/05/2009.

WOOLDRIDGE, Jeffrey M. Introdução à Econometria: uma abordagem moderna. São Paulo: Thomson Learning, 2007.

ZINGALES, Luigi; RAJAN, Raghuram G. Salvando o capitalismo dos capitalistas: acreditando no poder do livre mercado para criar mais riqueza e ampliar as oportunidades. Rio de Janeiro: Elsevier e Campus, 2004. 


\section{APÊNDICES}

APÊNDICE 1: EMPRESAS COM CÓDIGOS DA CNAE 2.0 QUE TINHAM MAIS DE UM CORRESPONDENTE NA CNAE 1.0

APÊNDICE 2: EFEITOS DA INTERAÇÃO ENTRE COMPETIÇÃO E QUALIDADE DE GOVERNANÇA SOBRE O DESEMPENHO 


\section{APÊNDICE 1: EMPRESAS COM CÓDIGOS DA CNAE 2.0 QUE TINHAM MAIS DE UM} CORRESPONDENTE NA CNAE 1.0

\begin{tabular}{llll}
\hline CÓDIGO & FIRMA & CNPJ & CNAE 2.0 \\
\hline 1 & Perdigao S/A & $01.838 .723 / 0001-27$ & $10.12-1$ \\
2 & Seara Alim & $02.914 .460 / 0001-50$ & $10.12-1$ \\
3 & Ecodiesel & $05.799 .312 / 0001-20$ & $20.99-1$ \\
4 & Vicunha Text & $07.332 .190 / 0001-93$ & $13.11-1$ \\
5 & Guararapes & $08.402 .943 / 0001-52$ & $14.12-6$ \\
6 & Santistextil & $15.082 .688 / 0001-73$ & $13.21-9$ \\
7 & Millennium & $15.115 .504 / 0001-24$ & $20.19-3$ \\
8 & Cedro & $17.245 .234 / 0001-00$ & $13.59-6$ \\
9 & Ind Cataguas & $19.526 .748 / 0001-50$ & $13.21-9$ \\
10 & Sadia S/A & $20.730 .099 / 0001-94$ & $10.12-1$ \\
11 & Santanense & $21.255 .567 / 0001-89$ & $13.21-9$ \\
12 & Paraibuna & $42.416 .651 / 0001-07$ & $24.49-1$ \\
13 & Le Lis Blanc & $49.669 .856 / 0001-43$ & $14.12-6$ \\
14 & Plascar Part & $51.928 .174 / 0001-50$ & $22.29-3$ \\
15 & Bic Monark & $56.992 .423 / 0001-90$ & $30.92-0$ \\
16 & Bic Caloi & $56.994 .924 / 0001-05$ & $30.92-0$ \\
17 & Ferro Ligas & $57.487 .142 / 0001-42$ & $30.92-0$ \\
18 & CBC Cartucho & $57.494 .031 / 0001-63$ & $25.50-1$ \\
19 & Dixie Toga & $60.394 .723 / 0001-44$ & $22.29-3$ \\
20 & Nordon Met & $60.884 .319 / 0001-59$ & $33.14-7$ \\
21 & Alpargatas & $61.079 .117 / 0001-05$ & $13.11-1$ \\
22 & Staroup & $61.087 .581 / 0001-35$ & $14.12-6$ \\
23 & Vigor & $61.116 .331 / 0001-86$ & $13.11-1$ \\
24 & Baumer & $61.374 .161 / 0001-30$ & $32.50-7$ \\
25 & Cremer & $82.641 .325 / 0001-18$ & $13.59-6$ \\
26 & Fab C Renaux & $82.981 .671 / 0001-45$ & $13.21-9$ \\
27 & Schlosser & $82.981 .929 / 0001-03$ & $13.21-9$ \\
28 & Tex Renaux & $82.982 .075 / 0001-80$ & $13.21-9$ \\
29 & Chapeco & $83.296 .889 / 0001-23$ & $10.12-1$ \\
30 & Mundial & $88.610 .191 / 0001-54$ & $32.99-0$ \\
31 & Marcopolo & $88.611 .835 / 0001-29$ & $29.30-1$ \\
32 & Pettenati & $88.613 .658 / 0001-10$ & $14.12-6$ \\
33 & Randon Part & $89.086 .144 / 0001-16$ & $29.30-1$ \\
34 & Trafo & $90.286 .105 / 0001-41$ & $27.10-4$ \\
35 & Recrusul & $91.333 .666 / 0001-17$ & $29.30-1$ \\
36 & Frangosul & $91.374 .561 / 0001-06$ & $10.12-1$ \\
37 & Forjas Taurus & $92.781 .335 / 0001-02$ & $25.50-1$ \\
38 & Excelsior & $95.426 .862 / 0001-97$ & $10.12-1$ \\
39 & Amadeo Rossi & $96.735 .105 / 0001-68$ & $25.50-1$ \\
\hline & & & \\
& & & \\
& & & \\
& & & \\
& & &
\end{tabular}




\section{APÊNDICE 2: EFEITOS DA INTERAÇÃO ENTRE COMPETIÇÃO E QUALIDADE DE GOVERNANÇA SOBRE O DESEMPENHO}

Tabela 1-A - Efeitos da interação entre competição no mercado de produtos e a qualidade de governança das companhias sobre o EBIT_AT: regressões utilizando o método de Efeitos Fixos e separação dos setores em competitivos e não competitivos pela mediana.

\begin{tabular}{|c|c|c|c|c|c|c|c|c|c|c|}
\hline \multirow[b]{2}{*}{$\underline{\text { Regressores }}$} & \multicolumn{10}{|c|}{ Variável dependente = EBIT_AT } \\
\hline & \multicolumn{2}{|c|}{ (i) } & \multicolumn{2}{|c|}{ (ii) } & \multicolumn{2}{|c|}{ (iii) } & \multicolumn{2}{|c|}{ (iv) } & \multicolumn{2}{|c|}{ (v) } \\
\hline IGOV & -0.00201 & $(0.00858)$ & -0.000356 & $(0.00784)$ & 0.0336 & $(0.0249)$ & 0.00169 & $(0.00802)$ & -0.00219 & $(0.00668)$ \\
\hline HHI_4LOW & 0.00755 & $(0.0429)$ & & & & & & & & \\
\hline IGOV X HHI_4LOW & 0.00921 & $(0.00926)$ & & & & & & & & \\
\hline HHI_3LOW & & & 0.00227 & $(0.0429)$ & & & & & & \\
\hline IGOV X HHI_3LOW & & & 0.000764 & $(0.00967)$ & & & & & & \\
\hline C4_3LOW & & & & & 0.122 & $(0.116)$ & & & & \\
\hline IGOV X C4_3LOW & & & & & -0.0222 & $(0.0304)$ & & & & \\
\hline NCOMP_4LOW & & & & & & & -0.0142 & $(0.0469)$ & & \\
\hline IGOV X NCOMP_4LOW & & & & & & & -0.00599 & $(0.0143)$ & & \\
\hline NCOMP_3LOW & & & & & & & & & 0.0000 & 0.0000 \\
\hline IGOV X NCOMP_3LOW & & & & & & & & & 0.0217 & $(0.0239)$ \\
\hline 3VDIR & -0.0546 & $(0.117)$ & -0.0312 & $(0.115)$ & 0.0577 & $(0.218)$ & -0.0216 & $(0.123)$ & -0.0244 & $(0.108)$ \\
\hline VOTE & -0.0652 & $(0.0583)$ & -0.0446 & $(0.0730)$ & -0.0124 & $(0.0921)$ & -0.0347 & $(0.0763)$ & -0.0862 & $(0.0927)$ \\
\hline CRESC & 0.00420 & $(0.00253)$ & 0.00379 & $(0.00244)$ & 0.00263 & $(0.00307)$ & 0.00368 & $(0.00258)$ & 0.00357 & $(0.00257)$ \\
\hline LEV & $-0.101 * * *$ & $(0.0255)$ & $-0.108^{* * *}$ & $(0.0272)$ & $-0.405 * *$ & $(0.173)$ & $-0.110 * * *$ & $(0.0293)$ & $-0.111 * * *$ & $(0.0254)$ \\
\hline TANG & 0.175 & $(0.108)$ & 0.151 & $(0.115)$ & 0.0138 & $(0.120)$ & 0.151 & $(0.105)$ & 0.139 & $(0.111)$ \\
\hline SIZE & 0.0559 & $(0.0476)$ & 0.0622 & $(0.0534)$ & 0.104 & $(0.0911)$ & 0.0540 & $(0.0504)$ & 0.0637 & $(0.0512)$ \\
\hline DIVYELD & 0.0756 & $(0.120)$ & 0.0894 & $(0.122)$ & $0.240^{*}$ & $(0.140)$ & 0.0870 & $(0.120)$ & 0.0961 & $(0.119)$ \\
\hline Intercepto & -0.605 & $(0.702)$ & -0.721 & $(0.798)$ & -1.407 & $(1.233)$ & -0.598 & $(0.732)$ & -0.737 & $(0.752)$ \\
\hline Dummies IDENT & \multicolumn{2}{|c|}{ SIM } & \multicolumn{2}{|c|}{ SIM } & \multicolumn{2}{|c|}{ SIM } & \multicolumn{2}{|c|}{ SIM } & \multicolumn{2}{|l|}{ SIM } \\
\hline Dummies IND & \multicolumn{2}{|c|}{ NÃO } & \multicolumn{2}{|c|}{ NÃO } & \multicolumn{2}{|c|}{ NÃO } & \multicolumn{2}{|c|}{ NÃO } & \multicolumn{2}{|c|}{ NÃO } \\
\hline Dummies ANO & \multicolumn{2}{|c|}{ SIM } & \multicolumn{2}{|c|}{ SIM } & \multicolumn{2}{|c|}{ SIM } & \multicolumn{2}{|c|}{ SIM } & \multicolumn{2}{|c|}{ SIM } \\
\hline Número de observações & \multicolumn{2}{|c|}{214} & \multicolumn{2}{|c|}{214} & \multicolumn{2}{|c|}{143} & \multicolumn{2}{|c|}{214} & \multicolumn{2}{|c|}{214} \\
\hline $\mathbf{R}^{2}$ & \multicolumn{2}{|c|}{0.277} & \multicolumn{2}{|c|}{0.244} & \multicolumn{2}{|c|}{0.494} & \multicolumn{2}{|c|}{0.254} & 0.2 & 551 \\
\hline
\end{tabular}

A variável dependente é o EBIT_AT apresentado na seção 3.2.3 e refere-se ao período de 2005 a 2007. Os regressores são: IGOV (qualidade de governança corporativa), HHI_4LOW (HHI calculado pela CNAE a 4 dígitos e pertencente à mediana superior), IGOVXHHI_4LOW (interação entre governança IGOV e HHI_4LOW), HHI_3LOW (HHI calculado pela CNAE a 3 dígitos e pertencente à mediana superior), IGOVXHHI_3LOW (interação entre governança IGOV e HHI_3LOW), C4_3LOW (C4 calculado pela CNAE a 3 dígitos e pertencente à mediana superior), NCOMP_4LOW (Competidores considerando CNAE a 4 dígitos e pertencentes à mediana inferior), IGOVXNCOMP_4LOW (interação entre governança IGOV e NCOMP_4LOW), NCOMP_3LOW (Competidores considerando CNAE a três dígitos e pertencentes à mediana inferior), IGOVXNCOMP_3LOW (interação entre governança IGOV e NCOMP_3LOW), 3VDIR (ações ordinárias do três principais acionistas), VOTE (participação das ações ordinárias no capital total da companhia), CRESC (crescimento), LEV (alavancagem), TANG (tangibilidade), SIZE (tamanho), DIVYELD (taxa de dividendos) e os conjuntos de dummies IDENT (tipo do acionista controlador) e ANO. As definições operacionais constam da seção 3.3. Os valores das distribuições utilizados para separar os setores em competitivos e não competitivos constam da Tabela 13. O erro-padrão de cada coeficiente figura entre parênteses. ***, ** e $*$ denotam a significância estatística das estimativas nos níveis de $1 \%, 5 \%$ e $10 \%$, respectivamente. Os erros-padrão foram calculados, para todos os métodos de estimação, utilizando-se os dados agrupados por empresa e são robustos a quaisquer formas de heterocedasticidade e autocorrelação dos erros do modelo. 
Tabela 2-A - Efeitos da interação entre competição no mercado de produtos e a qualidade de governança das companhias sobre o EBITDA_AT: regressões utilizando o método de Efeitos Fixos e separação dos setores em competitivos e não competitivos pela mediana.

\begin{tabular}{|c|c|c|c|c|c|c|c|c|c|c|}
\hline \multirow[b]{2}{*}{ Regressores } & \multicolumn{8}{|c|}{ Variável dependente = EBITDA_AT } & \multirow{2}{*}{\multicolumn{2}{|c|}{$(\mathbf{v})$}} \\
\hline & \multicolumn{2}{|c|}{ (i) } & \multicolumn{2}{|c|}{ (ii) } & \multicolumn{2}{|c|}{ (iii) } & \multicolumn{2}{|c|}{ (iv) } & & \\
\hline IGOV & -0.00527 & $(0.00859)$ & -0.00322 & $(0.00797)$ & 0.0323 & $(0.0263)$ & -0.00114 & $(0.00820)$ & -0.00476 & $(0.00686)$ \\
\hline HHI_4LOW & -0.000988 & $(0.0434)$ & & & & & & & & \\
\hline IGOV X HHI_4LOW & 0.0118 & $(0.00914)$ & & & & & & & & \\
\hline HHI_3LOW & & & -0.000952 & $(0.0449)$ & & & & & & \\
\hline IGOV X HHI_3LOW & & & 0.00314 & $(0.00984)$ & & & & & & \\
\hline C4_3LOW & & & & & 0.126 & $(0.123)$ & & & & \\
\hline IGOV X C4_3LOW & & & & & -0.0226 & $(0.0313)$ & & & & \\
\hline NCOMP_4LOW & & & & & & & -0.0159 & $(0.0476)$ & & \\
\hline IGOV X NCOMP_4LOW & & & & & & & -0.00547 & $(0.0144)$ & & \\
\hline NCOMP_3LOW & & & & & & & & & 0.0000 & 0.0000 \\
\hline IGOV X NCOMP_3LOW & & & & & & & & & 0.0209 & $(0.0234)$ \\
\hline 3VDIR & -0.0617 & $(0.119)$ & -0.0336 & $(0.116)$ & 0.0357 & $(0.209)$ & -0.0227 & $(0.123)$ & -0.0241 & $(0.110)$ \\
\hline VOTE & -0.0506 & $(0.0577)$ & -0.0304 & $(0.0720)$ & 0.00289 & $(0.0902)$ & -0.0157 & $(0.0761)$ & -0.0650 & $(0.0917)$ \\
\hline CRESC & 0.00388 & $(0.00255)$ & 0.00342 & $(0.00247)$ & 0.00215 & $(0.00321)$ & 0.00334 & $(0.00261)$ & 0.00323 & $(0.00259)$ \\
\hline LEV & $-0.0874 * * *$ & $(0.0238)$ & $-0.0962 * * *$ & $(0.0262)$ & $-0.417 * *$ & $(0.182)$ & $-0.0977 * * *$ & $(0.0279)$ & $-0.0993 * * *$ & $(0.0241)$ \\
\hline TANG & $0.198 *$ & $(0.108)$ & 0.172 & $(0.116)$ & 0.0332 & $(0.122)$ & 0.174 & $(0.106)$ & 0.162 & $(0.112)$ \\
\hline SIZE & 0.0580 & $(0.0486)$ & 0.0651 & $(0.0551)$ & 0.113 & $(0.102)$ & 0.0574 & $(0.0518)$ & 0.0674 & $(0.0528)$ \\
\hline DIVYELD & 0.0731 & $(0.128)$ & 0.0911 & $(0.131)$ & $0.256^{*}$ & $(0.149)$ & 0.0844 & $(0.129)$ & 0.0930 & $(0.128)$ \\
\hline Intercepto & -0.740 & $(0.732)$ & -0.763 & $(0.835)$ & -1.478 & (1.369) & -0.617 & $(0.752)$ & -0.814 & $(0.787)$ \\
\hline Dummies IDENT & SI & & SI & & & & SI & & SI & \\
\hline Dummies IND & $\mathrm{N} \tilde{A}$ & & $\mathrm{~N} \tilde{\mathrm{A}}$ & & & & $\mathrm{N} \hat{H}$ & & & $\mathrm{O}$ \\
\hline Dummies ANO & $\mathrm{SI}$ & & SI & & & & SI & & $\mathrm{SI}$ & \\
\hline Número de obs ervações & 21 & & 21 & & & & 2 & & & 12 \\
\hline $\mathbf{R}^{2}$ & 0.2 & & 0.2 & & & & 0.2 & & 0.2 & \\
\hline
\end{tabular}

A variável dependente é o EBITDA_AT apresentado na seção 3.2.3 e refere-se ao período de 2005 a 2007. Os regressores são: IGOV (qualidade de governança corporativa), HHI_4LOW (HHI calculado pela CNAE a 4 dígitos e pertencente à mediana superior), IGOVXHHI_4LOW (interação entre governança IGOV e HHI_4LOW), HHI_3LOW (HHI calculado pela CNAE a 3 dígitos e pertencente à mediana superior), IGOVXHHI_3LOW (interação entre governança IGOV e HHI_3LOW), C4_3LOW (C4 calculado pela CNAE a 3 dígitos e pertencente à mediana superior), NCOMP_4LOW (Competidores considerando CNAE a 4 dígitos e pertencentes à mediana inferior), IGOVXNCOMP_4LOW (interação entre governança IGOV e NCOMP_4LOW), NCOMP_3LOW (Competidores considerando CNAE a três dígitos e pertencentes à mediana inferior), IGOVXNCOMP_3LOW (interação entre governança IGOV e NCOMP_3LOW), 3VDIR (ações ordinárias do três principais acionistas), VOTE (participação das ações ordinárias no capital total da companhia), CRESC (crescimento), LEV (alavancagem), TANG (tangibilidade), SIZE (tamanho), DIVYELD (taxa de dividendos) e os conjuntos de dummies IDENT (tipo do acionista controlador) e ANO. As definições operacionais constam da seção 3.3. Os valores das distribuições utilizados para separar os setores em competitivos e não competitivos constam da Tabela 13. O erro-padrão de cada coeficiente figura entre parênteses. ***, ** e * denotam a significância estatística das estimativas nos níveis de 1\%, 5\% e 10\%, respectivamente. Os erros-padrão foram calculados, para todos os métodos de estimação, utilizando-se os dados agrupados por empresa e são robustos a quaisquer formas de heterocedasticidade e autocorrelação dos erros do modelo. 
Tabela 3-A - Efeitos da interação entre competição no mercado de produtos e a qualidade de governança das companhias sobre o EBITDA_REC: regressões utilizando o método de Efeitos Fixos e separação dos setores em competitivos e não competitivos pela mediana.

\begin{tabular}{|c|c|c|c|c|c|c|c|c|c|c|}
\hline \multirow[b]{2}{*}{ Regressores } & \multicolumn{8}{|c|}{ Variável dependente = EBITDA_REC } & \multirow{2}{*}{\multicolumn{2}{|c|}{ (v) }} \\
\hline & \multicolumn{2}{|c|}{ (i) } & \multicolumn{2}{|c|}{ (ii) } & \multicolumn{2}{|c|}{ (iii) } & \multicolumn{2}{|c|}{ (iv) } & & \\
\hline IGOV & 0.0129 & $(0.0171)$ & 0.0126 & $(0.0167)$ & 0.0457 & $(0.0606)$ & -0.0217 & $(0.0308)$ & 0.00756 & $(0.0148)$ \\
\hline HHI_4LOW & 0.00560 & $(0.0716)$ & & & & & & & & \\
\hline IGOV X HHI_4LOW & 0.00703 & $(0.0140)$ & & & & & & & & \\
\hline HHI_3LOW & & & -0.0323 & $(0.0613)$ & & & & & & \\
\hline IGOV X HHI_3LOW & & & 0.0102 & $(0.0132)$ & & & & & & \\
\hline C4_3LOW & & & & & 0.182 & $(0.311)$ & & & & \\
\hline IGOVX C4_3LOW & & & & & 0.0512 & $(0.0904)$ & & & & \\
\hline NCOMP_4LOW & & & & & & & -1.108 & $(0.865)$ & & \\
\hline IGOVX NCOMP_4LOW & & & & & & & 0.143 & $(0.114)$ & & \\
\hline NCOMP_3LOW & & & & & & & & & 0.0000 & 0.0000 \\
\hline IGOVXNCOMP_3LOW & & & & & & & & & 0.0794 & $(0.0708)$ \\
\hline 3VDIR & -0.0206 & $(0.150)$ & -0.00984 & $(0.151)$ & 0.184 & $(0.432)$ & -0.372 & $(0.238)$ & 0.0179 & $(0.157)$ \\
\hline VOTE & -0.173 & $(0.128)$ & -0.177 & $(0.132)$ & -0.351 & $(0.250)$ & -0.379 & $(0.260)$ & -0.317 & $(0.247)$ \\
\hline CRESC & 0.0286 & $(0.0210)$ & 0.0281 & $(0.0209)$ & 0.0469 & $(0.0378)$ & $0.0242 *$ & $(0.0137)$ & 0.0276 & $(0.0203)$ \\
\hline LEV & -0.130 & $(0.130)$ & -0.135 & $(0.131)$ & -0.324 & $(0.277)$ & -0.0722 & $(0.0827)$ & -0.147 & $(0.137)$ \\
\hline TANG & $-0.302^{*}$ & $(0.169)$ & $-0.333^{*}$ & $(0.173)$ & -0.521 & $(0.501)$ & $-0.276^{*}$ & $(0.150)$ & $-0.361 *$ & $(0.195)$ \\
\hline SIZE & 0.262 & (0.189) & 0.264 & $(0.190)$ & 0.475 & $(0.515)$ & $0.229 *$ & $(0.125)$ & 0.272 & (0.188) \\
\hline DIVYELD & -0.461 & $(0.508)$ & -0.438 & $(0.507)$ & -1.027 & (1.210) & -0.454 & $(0.405)$ & -0.420 & $(0.485)$ \\
\hline Intercepto & -3.119 & (2.498) & -3.144 & $(2.516)$ & -6.233 & $(6.638)$ & -1.894 & $(1.410)$ & -3.262 & (2.479) \\
\hline Dummies IDENT & \multicolumn{2}{|c|}{ SIM } & \multicolumn{2}{|c|}{ SIM } & \multicolumn{2}{|c|}{ SIM } & \multicolumn{2}{|c|}{ SIM } & \multicolumn{2}{|c|}{ SIM } \\
\hline Dummies IND & \multicolumn{2}{|c|}{ NÃO } & \multicolumn{2}{|c|}{ NÃO } & \multicolumn{2}{|c|}{ NÃO } & \multicolumn{2}{|c|}{ NÃO } & \multicolumn{2}{|c|}{ NÃO } \\
\hline Dummies ANO & \multicolumn{2}{|c|}{ SIM } & \multicolumn{2}{|c|}{ SIM } & \multicolumn{2}{|c|}{ SIM } & \multicolumn{2}{|c|}{ SIM } & \multicolumn{2}{|c|}{ SIM } \\
\hline Número de observações & \multicolumn{2}{|c|}{214} & \multicolumn{2}{|c|}{214} & \multicolumn{2}{|c|}{143} & \multicolumn{2}{|c|}{214} & \multicolumn{2}{|c|}{214} \\
\hline $\mathbf{R}^{2}$ & \multicolumn{2}{|c|}{0.135} & \multicolumn{2}{|c|}{0.134} & \multicolumn{2}{|c|}{0.192} & & & & \\
\hline
\end{tabular}

A variável dependente é o EBITDA_REC apresentado na seção 3.2.3 e refere-se ao período de 2005 a 2007. Os regressores são: IGOV (qualidade de governança corporativa), HHI_4LOW (HHI calculado pela CNAE a 4 dígitos e pertencente à mediana superior), IGOVXHHI_4LOW (interação entre governança IGOV e HHI_4LOW), HHI_3LOW (HHI calculado pela CNAE a 3 dígitos e pertencente à mediana superior), IGOVXHHI_3LOW (interação entre governança IGOV e HHI_3LOW), C4_3LOW (C4 calculado pela CNAE a 3 dígitos e pertencente à mediana superior), NCOMP_4LOW (Competidores considerando CNAE a 4 dígitos e pertencentes à mediana inferior), IGOVXNCOMP_4LOW (interação entre governança IGOV e NCOMP_4LOW), NCOMP_3LOW (Competidores considerando CNAE a três dígitos e pertencentes à mediana inferior), IGOVXNCOMP_3LOW (interação entre governança IGOV e NCOMP_3LOW), 3VDIR (ações ordinárias do três principais acionistas), VOTE (participação das ações ordinárias no capital total da companhia), CRESC (crescimento), LEV (alavancagem), TANG (tangibilidade), SIZE (tamanho), DIVYELD (taxa de dividendos) e os conjuntos de dummies IDENT (tipo do acionista controlador) e ANO. As definições operacionais constam da seção 3.3. Os valores das distribuições utilizados para separar os setores em competitivos e não competitivos constam da Tabela 13. O erro-padrão de cada coeficiente figura entre parênteses. $* * *, * *$ e $*$ denotam a significância estatística das estimativas nos níveis de $1 \%, 5 \%$ e $10 \%$, respectivamente. Os erros-padrão foram calculados, para todos os métodos de estimação, utilizando-se os dados agrupados por empresa e são robustos a quaisquer formas de heterocedasticidade e autocorrelação dos erros do modelo. 
Tabela 4-A - Efeitos da interação entre competição no mercado de produtos e a qualidade de governança das companhias sobre o TOBINSQ: regressões utilizando o método de Efeitos Fixos e separação dos setores em competitivos e não competitivos pela mediana.

\begin{tabular}{|c|c|c|c|c|c|c|c|c|c|c|}
\hline \multirow{3}{*}{$\begin{array}{l}\text { Regressores } \\
\text { IGOV }\end{array}$} & \multicolumn{8}{|c|}{ Variável dependente $=$ TOBINSQ } & \multirow{2}{*}{\multicolumn{2}{|c|}{ (v) }} \\
\hline & \multicolumn{2}{|c|}{ (i) } & \multicolumn{2}{|c|}{ (ii) } & \multicolumn{2}{|c|}{ (iii) } & \multicolumn{2}{|c|}{ (iv) } & & \\
\hline & 0.0341 & $(0.165)$ & 0.0818 & $(0.158)$ & 0.0520 & $(0.181)$ & -0.147 & $(0.265)$ & -0.0220 & $(0.170)$ \\
\hline HHI_4LOW & 0.933 & $(0.883)$ & & & & & & & & \\
\hline IGOV X HHI_4LOW & -0.154 & $(0.222)$ & & & & & & & & \\
\hline HHI_3LOW & & & 1.965 & $(1.751)$ & & & & & & \\
\hline IGOV X HHI_3LOW & & & -0.355 & $(0.367)$ & & & & & & \\
\hline C4_3LOW & & & & & -0.911 & $(1.204)$ & & & & \\
\hline IGOV X C4_3LOW & & & & & 0.185 & $(0.285)$ & & & & \\
\hline NCOMP_4LOW & & & & & & & -1.489 & $(1.317)$ & & \\
\hline IGOV X NCOMP_4LOW & & & & & & & 0.512 & $(0.455)$ & & \\
\hline NCOMP_3LOW & & & & & & & & & 0.0000 & 0.0000 \\
\hline IGOV X NCOMP_3LOW & & & & & & & & & 0.220 & $(0.340)$ \\
\hline 3VDIR & 4.702 & $(2.918)$ & 4.492 & $(2.793)$ & -0.570 & $(1.212)$ & 3.209 & (2.106) & 4.338 & $(2.620)$ \\
\hline VOTE & 0.219 & $(1.122)$ & 0.567 & $(1.427)$ & -0.739 & $(0.683)$ & -0.878 & $(1.021)$ & -0.496 & $(1.251)$ \\
\hline CRESC & 0.149 & $(0.158)$ & 0.151 & $(0.162)$ & -0.0277 & $(0.0273)$ & 0.140 & $(0.151)$ & 0.144 & $(0.156)$ \\
\hline TANG & 2.731 & $(2.287)$ & 3.094 & $(2.451)$ & 1.561 & $(1.051)$ & 2.412 & $(2.331)$ & 2.365 & (2.197) \\
\hline SIZE & 2.646 & $(2.780)$ & 2.828 & $(2.906)$ & -0.282 & $(0.403)$ & 2.957 & (3.029) & 2.667 & $(2.769)$ \\
\hline DIVYELD & -1.540 & (1.846) & -1.584 & (1.983) & 1.433 & $(1.420)$ & -1.315 & (1.758) & -1.314 & $(1.767)$ \\
\hline Intercepto & -38.15 & $(39.45)$ & -41.43 & $(42.11)$ & 5.408 & $(5.422)$ & -41.84 & $(42.71)$ & -38.32 & (39.42) \\
\hline Dummies IDENT & \multicolumn{2}{|c|}{ SIM } & \multicolumn{2}{|c|}{ SIM } & \multicolumn{2}{|c|}{ SIM } & \multicolumn{2}{|c|}{ SIM } & \multicolumn{2}{|c|}{ SIM } \\
\hline Dummies IND & \multicolumn{2}{|c|}{ NÃO } & \multicolumn{2}{|c|}{ NÃO } & \multicolumn{2}{|c|}{ NÃO } & \multicolumn{2}{|c|}{ NÃO } & \multicolumn{2}{|c|}{ NÃO } \\
\hline Dummies ANO & \multicolumn{2}{|c|}{ SIM } & \multicolumn{2}{|c|}{ SIM } & \multicolumn{2}{|c|}{ SIM } & \multicolumn{2}{|c|}{ SIM } & \multicolumn{2}{|c|}{ SIM } \\
\hline Número de obs ervações & \multicolumn{2}{|c|}{203} & \multicolumn{2}{|c|}{203} & \multicolumn{2}{|c|}{131} & \multicolumn{2}{|c|}{203} & \multicolumn{2}{|c|}{203} \\
\hline$\underline{\mathbf{R}}^{2}$ & \multicolumn{2}{|c|}{0.109} & \multicolumn{2}{|c|}{0.112} & \multicolumn{2}{|c|}{0.219} & & & & \\
\hline
\end{tabular}

A variável dependente é o TOBINSQ apresentado na seção 3.2.3 e refere-se ao período de 2005 a 2007 . Os regressores são: IGOV (qualidade de governança corporativa), HHI_4LOW (HHI calculado pela CNAE a 4 dígitos e pertencente à mediana superior), IGOVXHHI_4LOW (interação entre governança IGOV e HHI_4LOW), HHI_3LOW (HHI calculado pela CNAE a 3 dígitos e pertencente à mediana superior), IGOVXHHI_3LOW (interação entre governança IGOV e HHI_3LOW), C4_3LOW (C4 calculado pela CNAE a 3 dígitos e pertencente à mediana superior), NCOMP_4LOW (Competidores considerando CNAE a 4 dígitos e pertencentes à mediana inferior), IGOVXNCOMP_4LOW (interação entre governança IGOV e NCOMP_4LOW), NCOMP_3LOW (Competidores considerando CNAE a três dígitos e pertencentes à mediana inferior), IGOVXNCOMP_3LOW (interação entre governança IGOV e NCOMP_3LOW), 3VDIR (ações ordinárias do três principais acionistas), VOTE (participação das ações ordinárias no capital total da companhia), CRESC (crescimento), TANG (tangibilidade), SIZE (tamanho), DIVYELD (taxa de dividendos) e os conjuntos de dummies IDENT (tipo do acionista controlador) e ANO. As definições operacionais constam da seção 3.3. Os valores das distribuições utilizados para separar os setores em competitivos e não competitivos constam da Tabela 13. O erro-padrão de cada coeficiente figura entre parênteses. $* * *, * *$ e $*$ denotam a significância estatística das estimativas nos níveis de $1 \%, 5 \%$ e $10 \%$, respectivamente. Os erros-padrão foram calculados, para todos os métodos de estimação, utilizando-se os dados agrupados por empresa e são robustos a quaisquer formas de heterocedasticidade e autocorrelação dos erros do modelo. 
Tabela 5-A - Efeitos da interação entre competição no mercado de produtos e a qualidade de governança das companhias sobre o EBIT_AT: regressões utilizando o método de Efeitos Fixos e separação dos setores em competitivos e não competitivos pelo primeiro e último tercil

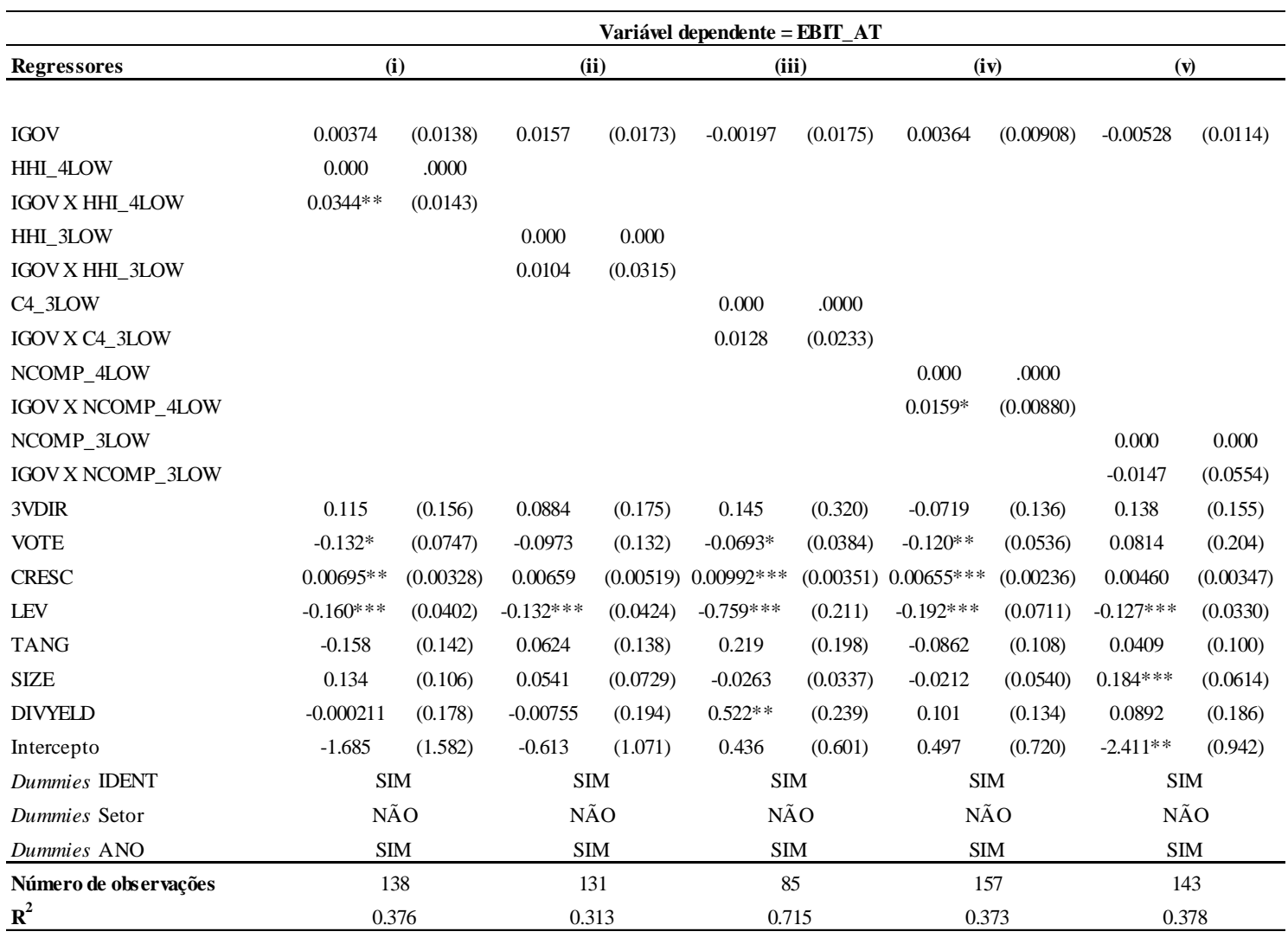

A variável dependente é o EBIT_AT apresentado na seção 3.2.3 e refere-se ao período de 2005 a 2007 . Os regressores são: IGOV (qualidade de governança corporativa), HHI_4LOW (HHI calculado pela CNAE a 4 dígitos e pertencente à mediana superior), IGOVXHHI_4LOW (interação entre governança IGOV e HHI_4LOW), HHI_3LOW (HHI calculado pela CNAE a 3 dígitos e pertencente à mediana superior), IGOVXHHI_3LOW (interação entre governança IGOV e HHI_3LOW), C4_3LOW (C4 calculado pela CNAE a 3 dígitos e pertencente à mediana superior), NCOMP_4LOW (Competidores considerando CNAE a 4 dígitos e pertencentes à mediana inferior), IGOVXNCOMP_4LOW (interação entre governança IGOV e NCOMP_4LOW), NCOMP_3LOW (Competidores considerando CNAE a três dígitos e pertencentes à mediana inferior), IGOVXNCOMP_3LOW (interação entre governança IGOV e NCOMP_3LOW), 3VDIR (ações ordinárias do três principais acionistas), VOTE (participação das ações ordinárias no capital total da companhia), CRESC (crescimento), LEV (alavancagem), TANG (tangibilidade), SIZE (tamanho), DIVYELD (taxa de dividendos) e os conjuntos de dummies IDENT (tipo do acionista controlador) e ANO. As definições operacionais constam da seção 3.3. Os valores das distribuições utilizados para separar os setores em competitivos e não competitivos constam da Tabela 13. O erro-padrão de cada coeficiente figura entre parênteses. $* * *, * *$ e $*$ denotam a significância estatística das estimativas nos níveis de $1 \%, 5 \%$ e $10 \%$, respectivamente. Os erros-padrão foram calculados, para todos os métodos de estimação, utilizando-se os dados agrupados por empresa e são robustos a quaisquer formas de heterocedasticidade e autocorrelação dos erros do modelo. 
Tabela 6-A - Efeitos da interação entre competição no mercado de produtos e a qualidade de governança das companhias sobre o EBITDA_AT: regressões utilizando o método de Efeitos Fixos e separação dos setores em competitivos e não competitivos pelo primeiro e último tercil

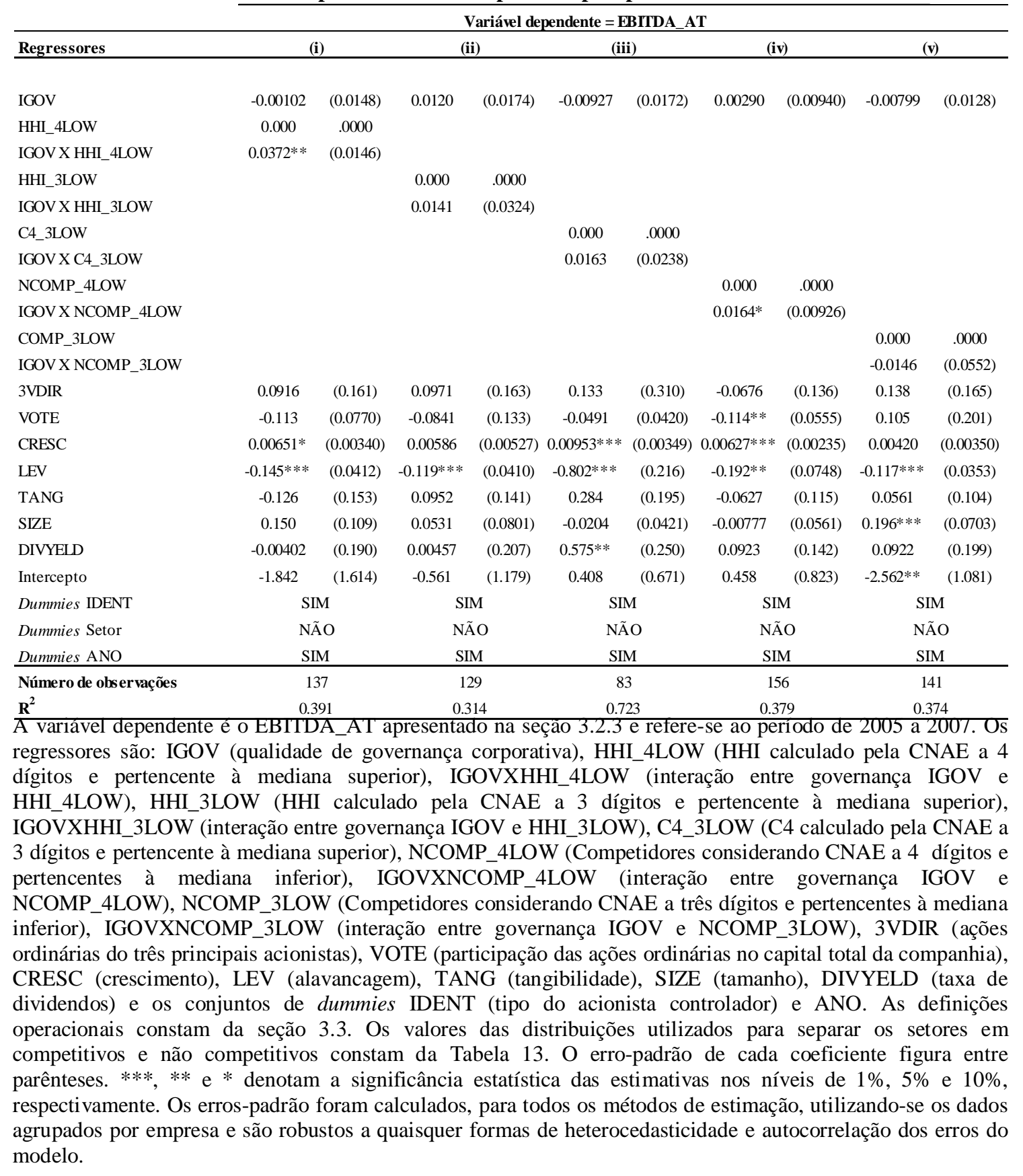


Tabela 7-A - Efeitos da interação entre competição no mercado de produtos e a qualidade de governança das companhias sobre o EBITDA_REC: regressões utilizando o método de Efeitos Fixos e separação dos setores em competitivos e não competitivos pelo primeiro e último tercil

\begin{tabular}{|c|c|c|c|c|c|c|c|c|c|c|}
\hline \multirow{3}{*}{$\begin{array}{l}\text { Regressores } \\
\text { IGOV }\end{array}$} & \multicolumn{10}{|c|}{ Variável dependente = EBITDA_REC } \\
\hline & \multicolumn{2}{|c|}{ (i) } & \multicolumn{2}{|c|}{ (ii) } & \multicolumn{2}{|c|}{ (iii) } & \multicolumn{2}{|c|}{ (iv) } & \multicolumn{2}{|c|}{ (v) } \\
\hline & 0.00686 & $(0.0108)$ & 0.0149 & $(0.0532)$ & 0.0492 & $(0.169)$ & -0.00596 & $(0.00913)$ & -0.0231 & $(0.0372)$ \\
\hline HHI_4LOW & 0.000 & .0000 & & & & & & & & \\
\hline IGOV X HHI_4LOW & 0.00925 & $(0.0121)$ & & & & & & & & \\
\hline HHI_3LOW & & & 0.000 & .0000 & & & & & & \\
\hline IGOV X HHI_3LOW & & & 0.0156 & $(0.0683)$ & & & & & & \\
\hline C4_3LOW & & & & & 0.000 & .0000 & & & & \\
\hline IGOVX X4_3LOW & & & & & -0.0716 & $(0.238)$ & & & & \\
\hline NCOMP_4LOW & & & & & & & 0.000 & .0000 & & \\
\hline IGOV X NCOMP_4LOW & & & & & & & 0.0143 & $(0.0103)$ & & \\
\hline NCOMP_3LOW & & & & & & & & & 0.000 & .0000 \\
\hline IGOV X NCOMP_3LOW & & & & & & & & & 0.135 & $(0.161)$ \\
\hline 3VDIR & 0.0140 & $(0.105)$ & 0.0835 & $(0.265)$ & 1.460 & $(1.365)$ & $-0.153^{*}$ & $(0.0870)$ & 0.508 & $(0.513)$ \\
\hline VOTE & -0.0836 & $(0.0548)$ & -0.183 & $(0.298)$ & -0.184 & $(0.595)$ & -0.0762 & $(0.0698)$ & -0.528 & $(0.604)$ \\
\hline CRESC & $0.00828 * *$ & $(0.00362)$ & 0.0549 & $(0.0464)$ & 0.102 & $(0.0831)$ & $0.00960 * *$ & $(0.00445)$ & 0.0312 & $(0.0258)$ \\
\hline LEV & $-0.0571^{*}$ & $(0.0312)$ & -0.199 & $(0.143)$ & -0.205 & $(0.560)$ & -0.0264 & $(0.0499)$ & -0.332 & $(0.275)$ \\
\hline TANG & -0.157 & $(0.139)$ & -0.380 & $(0.461)$ & -0.854 & $(0.993)$ & $-0.262^{* *}$ & $(0.111)$ & -0.470 & $(0.422)$ \\
\hline SIZE & 0.0457 & $(0.0623)$ & 0.323 & $(0.411)$ & 0.485 & $(0.639)$ & $0.202 * * *$ & $(0.0657)$ & 0.522 & $(0.384)$ \\
\hline DIVYELD & 0.0350 & $(0.125)$ & -1.078 & $(1.016)$ & -2.800 & (2.866) & 0.0717 & $(0.124)$ & -0.715 & $(0.780)$ \\
\hline Intercepto & -0.356 & $(0.892)$ & -4.212 & $(5.649)$ & -7.023 & $(8.564)$ & $-2.283 * * *$ & $(0.850)$ & -7.213 & $(5.517)$ \\
\hline Dummies IDENT & \multicolumn{2}{|c|}{ SIM } & \multicolumn{2}{|c|}{ SIM } & \multicolumn{2}{|c|}{ SIM } & \multicolumn{2}{|c|}{ SIM } & \multicolumn{2}{|c|}{ SIM } \\
\hline Dummies Setor & \multicolumn{2}{|c|}{ NÃO } & \multicolumn{2}{|c|}{ NÃO } & \multicolumn{2}{|c|}{ NÃO } & \multicolumn{2}{|c|}{ NÃO } & \multicolumn{2}{|c|}{ NÃO } \\
\hline Dummies ANO & \multicolumn{2}{|c|}{ SIM } & \multicolumn{2}{|c|}{ SIM } & \multicolumn{2}{|c|}{ SIM } & \multicolumn{2}{|c|}{ SIM } & \multicolumn{2}{|c|}{ SIM } \\
\hline Número de obs ervações & & \multicolumn{2}{|c|}{131} & \multicolumn{2}{|c|}{85} & \multicolumn{2}{|c|}{157} & \multicolumn{2}{|c|}{143} \\
\hline$\underline{\mathbf{R}}^{2}$ & \multicolumn{2}{|c|}{0.261} & \multicolumn{2}{|c|}{0.165} & \multicolumn{2}{|c|}{0.282} & \multicolumn{2}{|c|}{0.491} & 0.1 & 95 \\
\hline
\end{tabular}

A variável dependente é o EBITDA_REC apresentado na seção 3.2.3 e refere-se ao período de 2005 a 2007 . Os regressores são: IGOV (qualidade de governança corporativa), HHI_4LOW (HHI calculado pela CNAE a 4 dígitos e pertencente à mediana superior), IGOVXHHI_4LOW (interação entre governança IGOV e HHI_4LOW), HHI_3LOW (HHI calculado pela CNAE a 3 dígitos e pertencente à mediana superior), IGOVXHHI_3LOW (interação entre governança IGOV e HHI_3LOW), C4_3LOW (C4 calculado pela CNAE a 3 dígitos e pertencente à mediana superior), NCOMP_4LOW (Competidores considerando CNAE a 4 dígitos e pertencentes à mediana inferior), IGOVXNCOMP_4LOW (interação entre governança IGOV e NCOMP_4LOW), NCOMP_3LOW (Competidores considerando CNAE a três dígitos e pertencentes à mediana inferior), IGOVXNCOMP_3LOW (interação entre governança IGOV e NCOMP_3LOW), 3VDIR (ações ordinárias do três principais acionistas), VOTE (participação das ações ordinárias no capital total da companhia), CRESC (crescimento), LEV (alavancagem), TANG (tangibilidade), SIZE (tamanho), DIVYELD (taxa de dividendos) e os conjuntos de dummies IDENT (tipo do acionista controlador) e ANO. As definições operacionais constam da seção 3.3. Os valores das distribuições utilizados para separar os setores em competitivos e não competitivos constam da Tabela 13. O erro-padrão de cada coeficiente figura entre parênteses. $* * *, * *$ e $*$ denotam a significância estatística das estimativas nos níveis de $1 \%, 5 \%$ e $10 \%$, respectivamente. Os erros-padrão foram calculados, para todos os métodos de estimação, utilizando-se os dados agrupados por empresa e são robustos a quaisquer formas de heterocedasticidade e autocorrelação dos erros do modelo. 
Tabela 8-A - Efeitos da interação entre competição no mercado de produtos e a qualidade de governança das companhias sobre o TOBINSQ: regressões utilizando o método de Efeitos Fixos e separação dos setores em competitivos e não competitivos pelo primeiro e último tercil

\begin{tabular}{|c|c|c|c|c|c|c|c|c|c|c|}
\hline \multirow[b]{2}{*}{ Regressores } & \multicolumn{8}{|c|}{ Variável dependente = TOB INSQ } & \multirow{2}{*}{\multicolumn{2}{|c|}{ (v) }} \\
\hline & \multicolumn{2}{|c|}{ (i) } & \multicolumn{2}{|c|}{ (ii) } & \multicolumn{2}{|c|}{ (iii) } & \multicolumn{2}{|c|}{ (iv) } & & \\
\hline IGOV & -1.091 & $(0.996)$ & -0.591 & $(0.718)$ & 0.104 & $(0.205)$ & -0.684 & $(0.694)$ & -0.422 & $(0.362)$ \\
\hline HHI_4LOW & 0.000 & .0000 & & & & & & & & \\
\hline IGOV X HHI_4LOW & 0.349 & $(0.406)$ & & & & & & & & \\
\hline HHI_3LOW & & & 0.000 & .0000 & & & & & & \\
\hline IGOV X HHI_3LOW & & & -0.313 & $(1.429)$ & & & & & & \\
\hline C4_3LOW & & & & & 0.000 & .0000 & & & & \\
\hline IGOV X C4_3LOW & & & & & 0.774 & $(0.663)$ & & & & \\
\hline NCOMP_4LOW & & & & & & & 0.000 & .0000 & & \\
\hline IGOV X NCOMP_4LOW & & & & & & & 0.123 & $(0.383)$ & & \\
\hline NCOMP_3LOW & & & & & & & & & 0.000 & .0000 \\
\hline IGOV X NCOMP_3LOW & & & & & & & & & 0.0276 & $(1.030)$ \\
\hline 3VDIR & -4.271 & $(6.967)$ & 1.779 & $(5.000)$ & -1.484 & $(1.978)$ & -3.308 & $(3.979)$ & 8.486 & $(5.233)$ \\
\hline VOTE & 2.577 & (3.715) & 3.134 & $(7.130)$ & -2.884 & $(2.007)$ & 2.218 & $(2.743)$ & 1.326 & $(4.945)$ \\
\hline CRESC & 0.147 & $(0.163)$ & 0.451 & $(0.470)$ & -0.121 & $(0.0852)$ & 0.132 & $(0.137)$ & 0.204 & $(0.215)$ \\
\hline TANG & -3.032 & $(4.803)$ & 2.419 & (3.836) & 0.567 & $(1.952)$ & 9.509 & $(9.254)$ & -1.100 & (3.323) \\
\hline SIZE & 12.00 & $(9.529)$ & 6.842 & $(6.839)$ & -0.843 & $(0.813)$ & 7.782 & (7.284) & 6.421 & $(5.781)$ \\
\hline DIVYELD & -1.743 & $(3.869)$ & -5.308 & $(6.466)$ & 1.854 & $(2.604)$ & -1.541 & $(2.701)$ & -0.0450 & $(2.654)$ \\
\hline Intercepto & -167.8 & $(135.3)$ & -95.77 & $(96.30)$ & 14.59 & (11.27) & -98.39 & $(93.89)$ & -87.51 & (79.84) \\
\hline Dummies IDENT & \multicolumn{2}{|c|}{ SIM } & \multicolumn{2}{|c|}{ SIM } & \multicolumn{2}{|c|}{ SIM } & \multicolumn{2}{|c|}{ SIM } & \multicolumn{2}{|c|}{ SIM } \\
\hline Dummies Setor & \multicolumn{2}{|c|}{ NÃO } & \multicolumn{2}{|c|}{ NÃO } & \multicolumn{2}{|c|}{ NÃO } & \multicolumn{2}{|c|}{ NÃO } & \multicolumn{2}{|c|}{ NÃO } \\
\hline Dummies ANO & \multicolumn{2}{|c|}{ SIM } & \multicolumn{2}{|c|}{ SIM } & \multicolumn{2}{|c|}{ SIM } & \multicolumn{2}{|c|}{ SIM } & \multicolumn{2}{|c|}{ SIM } \\
\hline Número de obs ervações & \multicolumn{2}{|c|}{135} & \multicolumn{2}{|c|}{124} & \multicolumn{2}{|c|}{78} & \multicolumn{2}{|c|}{153} & \multicolumn{2}{|c|}{137} \\
\hline $\mathbf{R}^{2}$ & \multicolumn{2}{|c|}{0.296} & \multicolumn{2}{|c|}{0.233} & \multicolumn{2}{|c|}{0.297} & & & & \\
\hline
\end{tabular}

A variável dependente é o TOBINSQ apresentado na seção 3.2.3 e refere-se ao período de 2005 a 2007. Os regressores são: IGOV (qualidade de governança corporativa), HHI_4LOW (HHI calculado pela CNAE a 4 dígitos e pertencente à mediana superior), IGOVXHHI_4LOW (interação entre governança IGOV e HHI_4LOW), HHI_3LOW (HHI calculado pela CNAE a 3 dígitos e pertencente à mediana superior), IGOVXHHI_3LOW (interação entre governança IGOV e HHI_3LOW), C4_3LOW (C4 calculado pela CNAE a 3 dígitos e pertencente à mediana superior), NCOMP_4LOW (Competidores considerando CNAE a 4 dígitos e pertencentes à mediana inferior), IGOVXNCOMP_4LOW (interação entre governança IGOV e NCOMP_4LOW), NCOMP_3LOW (Competidores considerando CNAE a três dígitos e pertencentes à mediana inferior), IGOVXNCOMP_3LOW (interação entre governança IGOV e NCOMP_3LOW), 3VDIR (ações ordinárias do três principais acionistas), VOTE (participação das ações ordinárias no capital total da companhia), CRESC (crescimento), TANG (tangibilidade), SIZE (tamanho), DIVYELD (taxa de dividendos) e os conjuntos de dummies IDENT (tipo do acionista controlador) e ANO. As definições operacionais constam da seção 3.3. Os valores das distribuições utilizados para separar os setores em competitivos e não competitivos constam da Tabela 13. O erro-padrão de cada coeficiente figura entre parênteses. ***, ** e * denotam a significância estatística das estimativas nos níveis de $1 \%, 5 \%$ e $10 \%$, respectivamente. Os erros-padrão foram calculados, para todos os métodos de estimação, utilizando-se os dados agrupados por empresa e são robustos a quaisquer formas de heterocedasticidade e autocorrelação dos erros do modelo. 
Tabela 9-A - Efeitos da interação entre competição no mercado de produtos e a qualidade de governança das companhias sobre o desempenho: regressões utilizando o método de Efeitos Fixos e separação dos setores em competitivos e não competitivos pelo critério do DOJ para o HHI_4

Critério DOJ: HHI_4

\begin{tabular}{|c|c|c|c|c|c|c|c|c|}
\hline Regressores & \multicolumn{2}{|c|}{ (i) } & \multicolumn{2}{|c|}{ (ii) } & \multicolumn{2}{|c|}{ (iii) } & \multicolumn{2}{|c|}{ (iv) } \\
\hline IGOV & -0.00451 & $(0.00987)$ & -0.00567 & $(0.0106)$ & -0.0266 & $(0.0363)$ & -0.721 & $(0.733)$ \\
\hline HHI_4DOJLOW & 0.0000 & $(0.0000)$ & 0.0000 & $(0.0000)$ & 0.0000 & $(0.0000)$ & 0.0000 & $(0.0000)$ \\
\hline IGOV X HHI_4DOJLOW & $0.0365 * *$ & $(0.0141)$ & $0.0391 * * *$ & $(0.0143)$ & 0.107 & $(0.0973)$ & 0.386 & $(0.404)$ \\
\hline 3VDIR & 0.0178 & $(0.122)$ & 0.0230 & $(0.123)$ & -0.243 & $(0.274)$ & -2.554 & $(5.863)$ \\
\hline VOTE & $-0.123^{*}$ & $(0.0713)$ & -0.116 & $(0.0729)$ & -0.301 & $(0.254)$ & 0.925 & $(2.735)$ \\
\hline CRESC & $0.00651 * *$ & $(0.00288)$ & $0.00611 * *$ & $(0.00297)$ & 0.0365 & $(0.0269)$ & 0.164 & $(0.170)$ \\
\hline LEV & $-0.116^{* * *}$ & $(0.0331)$ & $-0.109 * * *$ & $(0.0328)$ & -0.108 & $(0.0914)$ & & \\
\hline TANG & -0.134 & $(0.115)$ & -0.110 & $(0.125)$ & -0.730 & $(0.588)$ & -4.719 & $(5.040)$ \\
\hline SIZE & $0.131 *$ & $(0.0666)$ & 0.130 & $(0.0788)$ & 0.551 & $(0.431)$ & 9.181 & (7.934) \\
\hline DIVYELD & 0.0369 & $(0.144)$ & 0.0308 & -0.154 & -0.770 & $(0.755)$ & -2.311 & $(3.499)$ \\
\hline Intercepto & $-1.586^{*}$ & $(0.921)$ & -1.562 & (1.077) & -6.691 & (5.368) & -125.4 & $(110.0)$ \\
\hline Dummies IDENT & \multicolumn{2}{|c|}{ SIM } & \multicolumn{2}{|c|}{ SIM } & \multicolumn{2}{|c|}{ SIM } & \multicolumn{2}{|c|}{ SIM } \\
\hline Dummies IND & \multicolumn{2}{|c|}{ NÃO } & \multicolumn{2}{|c|}{ NÃO } & \multicolumn{2}{|c|}{ NÃO } & \multicolumn{2}{|c|}{ NÃO } \\
\hline Dummies ANO & \multicolumn{2}{|c|}{ SIM } & \multicolumn{2}{|c|}{ SIM } & \multicolumn{2}{|c|}{ SIM } & \multicolumn{2}{|c|}{ SIM } \\
\hline Número de obs ervações & \multicolumn{2}{|c|}{169} & \multicolumn{2}{|c|}{167} & \multicolumn{2}{|c|}{169} & \multicolumn{2}{|c|}{159} \\
\hline $\mathbf{R}^{2}$ & \multicolumn{2}{|c|}{0.370} & \multicolumn{2}{|c|}{0.367} & \multicolumn{2}{|c|}{0.200} & \multicolumn{2}{|c|}{0.237} \\
\hline
\end{tabular}

As variáveis dependentes são EBIT_AT, EBITDA_AT, EBITDA_REC e TOBINSQ, nas colunas i, ii, iii e iv, respectivamente. Estas variáveis foram apresentadas na seção 3.2.3 e referem-se ao período de 2005 a 2007 . Os regressores são: IGOV (qualidade de governança corporativa), HHI_4LOW (HHI calculado pela CNAE a 4 dígitos e pertencente à mediana superior), IGOVXHHI_4LOW (interação entre governança IGOV e HHI_4LOW), HHI_3LOW (HHI calculado pela CNAE a 3 dígitos e pertencente à mediana superior), IGOVXHHI_3LOW (interação entre governança IGOV e HHI_3LOW), C4_3LOW (C4 calculado pela CNAE a 3 dígitos e pertencente à mediana superior), NCOMP_4LOW (Competidores considerando CNAE a 4 dígitos e pertencentes à mediana inferior), IGOVXNCOMP_4LOW (interação entre governança IGOV e NCOMP_4LOW), NCOMP_3LOW (Competidores considerando CNAE a três dígitos e pertencentes à mediana inferior), IGOVXNCOMP_3LOW (interação entre governança IGOV e NCOMP_3LOW), 3VDIR (ações ordinárias do três principais acionistas), VOTE (participação das ações ordinárias no capital total da companhia), CRESC (crescimento), LEV(alavancagem), TANG (tangibilidade), SIZE (tamanho), DIVYELD (taxa de dividendos) e os conjuntos de dummies IDENT (tipo do acionista controlador) e ANO. As definições operacionais constam da seção 3.3. Os setores foram separados em competitivos e não competitivos conforme os intervalos do HHI elaborados pelo DOJ, como descrito na seção 3.5. O erro-padrão de cada coeficiente figura entre parênteses. $* * *, * *$ e * denotam a significância estatística das estimativas nos níveis de $1 \%, 5 \%$ e $10 \%$, respectivamente. Os erros-padrão foram calculados, para todos os métodos de estimação, utilizando-se os dados agrupados por empresa e são robustos a quaisquer formas de heterocedasticidade e autocorrelação dos erros do modelo. 
Tabela 10-A - Efeitos da interação entre competição no mercado de produtos e a qualidade de governança das companhias sobre o desempenho: regressões utilizando o método de Efeitos Fixos e separação dos setores em competitivos e não competitivos pelo critério do DOJ para o HHI_3

Critério DOJ: HHI_3

\begin{tabular}{|c|c|c|c|c|c|c|c|c|}
\hline Regressores & \multicolumn{2}{|c|}{ (i) } & \multicolumn{2}{|c|}{ (ii) } & \multicolumn{2}{|c|}{ (iii) } & \multicolumn{2}{|c|}{ (iv) } \\
\hline IGOV & 0.00166 & $(0.00870)$ & -0.000923 & $(0.00882)$ & 0.00682 & $(0.00963)$ & 0.000927 & $(0.102)$ \\
\hline HHI_3DOJLOW & -0.0881 & $(0.0658)$ & -0.0883 & $(0.0652)$ & -0.0458 & $(0.0889)$ & 0.140 & $(0.914)$ \\
\hline IGOV X HHI_3DOJLOW & 0.0217 & $(0.0142)$ & $0.0236^{*}$ & $(0.0141)$ & 0.0149 & $(0.0200)$ & -0.0706 & $(0.200)$ \\
\hline 3VDIR & -0.0737 & $(0.136)$ & -0.0781 & $(0.137)$ & -0.170 & $(0.109)$ & 2.349 & $(1.750)$ \\
\hline VOTE & -0.130 & $(0.0942)$ & -0.118 & $(0.0930)$ & -0.124 & $(0.123)$ & -0.0568 & $(0.858)$ \\
\hline CRESC & $0.00534 * *$ & $(0.00208)$ & $0.00504 * *$ & $(0.00211)$ & $0.00765^{* *}$ & $(0.00327)$ & -0.0136 & $(0.0195)$ \\
\hline LEV & $-0.111 * * *$ & $(0.0288)$ & $-0.0975 * * *$ & $(0.0266)$ & -0.00633 & $(0.0265)$ & & \\
\hline TANG & 0.119 & $(0.111)$ & 0.145 & $(0.111)$ & -0.213 & $(0.156)$ & $1.500^{*}$ & $(0.816)$ \\
\hline SIZE & 0.0367 & $(0.0523)$ & 0.0376 & $(0.0528)$ & 0.0825 & $(0.0809)$ & -0.0640 & $(0.211)$ \\
\hline DIVYELD & 0.0467 & $(0.120)$ & 0.0400 & $(0.128)$ & 0.0191 & $(0.0984)$ & 0.241 & $(0.942)$ \\
\hline Intercepto & -0.264 & $(0.790)$ & -0.350 & $(0.818)$ & -0.685 & (1.148) & 0.261 & (4.107) \\
\hline Dummies IDENT & \multicolumn{2}{|c|}{ SIM } & \multicolumn{2}{|c|}{ SIM } & \multicolumn{2}{|c|}{ SIM } & \multicolumn{2}{|c|}{ SIM } \\
\hline Dummies IND & \multicolumn{2}{|c|}{ NÃO } & \multicolumn{2}{|c|}{ NÃO } & \multicolumn{2}{|c|}{ NÃO } & \multicolumn{2}{|c|}{ NÃO } \\
\hline Dummies ANO & \multicolumn{2}{|c|}{ SIM } & \multicolumn{2}{|c|}{ SIM } & \multicolumn{2}{|c|}{ SIM } & \multicolumn{2}{|c|}{ SIM } \\
\hline Número de obs ervações & \multicolumn{2}{|c|}{195} & \multicolumn{2}{|c|}{193} & \multicolumn{2}{|c|}{195} & \multicolumn{2}{|c|}{184} \\
\hline $\mathbf{R}^{2}$ & \multicolumn{2}{|c|}{0.265} & \multicolumn{2}{|c|}{0.269} & \multicolumn{2}{|c|}{0.277} & \multicolumn{2}{|c|}{0.284} \\
\hline
\end{tabular}

variáveis dependentes são EBIT_AT, EBITDA_AT, EBITDA_REC e TOBINSQ, nas colunas i, ii, iii e iv, respectivamente. Estas variáveis foram apresentadas na seção 3.2.3 e referem-se ao período de 2005 a 2007. Os regressores são: IGOV (qualidade de governança corporativa), HHI_4LOW (HHI calculado pela CNAE a 4 dígitos e pertencente à mediana superior), IGOVXHHI_4LOW (interação entre governança IGOV e HHI_4LOW), HHI_3LOW (HHI calculado pela CNAE a 3 dígitos e pertencente à mediana superior), IGOVXHHI_3LOW (interação entre governança IGOV e HHI_3LOW), C4_3LOW (C4 calculado pela CNAE a 3 dígitos e pertencente à mediana superior), NCOMP_4LOW (Competidores considerando CNAE a 4 dígitos e pertencentes à mediana inferior), IGOVXNCOMP_4LOW (interação entre governança IGOV e NCOMP_4LOW), NCOMP_3LOW (Competidores considerando CNAE a três dígitos e pertencentes à mediana inferior), IGOVXNCOMP_3LOW (interação entre governança IGOV e NCOMP_3LOW), 3VDIR (ações ordinárias do três principais acionistas), VOTE (participação das ações ordinárias no capital total da companhia), CRESC (crescimento), LEV(alavancagem), TANG (tangibilidade), SIZE (tamanho), DIVYELD (taxa de dividendos) e os conjuntos de dummies IDENT (tipo do acionista controlador) e ANO. As definições operacionais constam da seção 3.3. Os setores foram separados em competitivos e não competitivos conforme os intervalos do HHI elaborados pelo DOJ, como descrito na seção 3.5. O erro-padrão de cada coeficiente figura entre parênteses. $* * *, * * \mathrm{e}^{*}$ denotam a significância estatística das estimativas nos níveis de $1 \%, 5 \%$ e $10 \%$, respectivamente. Os erros-padrão foram calculados, para todos os métodos de estimação, utilizando-se os dados agrupados por empresa e são robustos a quaisquer formas de heterocedasticidade e autocorrelação dos erros do modelo. 
Tabela 11-A - Efeitos da interação entre competição no mercado de produtos e a qualidade de governança das companhias sobre o desempenho: regressões utilizando o método de Efeitos Fixos e separação dos setores em competitivos e não competitivos pelo critério do CADE para o C4_3

Critério DOJ: C4_CADE

\begin{tabular}{|c|c|c|c|c|c|c|c|c|}
\hline Regressores & \multicolumn{2}{|c|}{ (i) } & \multicolumn{2}{|c|}{ (ii) } & \multicolumn{2}{|c|}{ (iii) } & \multicolumn{2}{|c|}{ (iv) } \\
\hline IGOV & -0.000183 & $(0.00758)$ & -0.00305 & $(0.00770)$ & 0.0160 & $(0.0176)$ & -0.0459 & $(0.233)$ \\
\hline C4_CADE & -0.0377 & $(0.0701)$ & -0.0354 & $(0.0757)$ & -0.0871 & $(0.0589)$ & -19.67 & $(12.95)$ \\
\hline IGOV X C4_CADE & 0.00735 & $(0.0154)$ & 0.00633 & $(0.0163)$ & $0.0209 * *$ & $(0.00965)$ & 3.253 & $(2.195)$ \\
\hline 3VDIR & -0.0396 & $(0.115)$ & -0.0396 & $(0.116)$ & -0.0183 & $(0.163)$ & -3.063 & $(4.424)$ \\
\hline VOTE & -0.0559 & $(0.0652)$ & -0.0349 & $(0.0670)$ & $-0.191 *$ & $(0.114)$ & -7.086 & $(5.070)$ \\
\hline CRESC & 0.00372 & $(0.00260)$ & 0.00339 & $(0.00263)$ & 0.0281 & (0.0209) & 0.0596 & $(0.0534)$ \\
\hline $\mathrm{LEV}$ & $-0.108 * * *$ & $(0.0272)$ & $-0.0952 * * *$ & $(0.0258)$ & -0.139 & $(0.134)$ & & \\
\hline TANG & 0.153 & $(0.108)$ & 0.174 & $(0.108)$ & $-0.308 *$ & $(0.166)$ & 2.242 & $(2.163)$ \\
\hline SIZE & 0.0631 & $(0.0524)$ & 0.0663 & $(0.0541)$ & 0.270 & $(0.191)$ & 1.665 & $(1.302)$ \\
\hline DIVYELD & 0.0890 & $(0.119)$ & 0.0850 & $(0.128)$ & -0.440 & $(0.507)$ & -1.029 & $(1.234)$ \\
\hline Intercepto & -0.718 & $(0.767)$ & -0.767 & $(0.807)$ & -3.232 & $(2.554)$ & -15.52 & $(16.76)$ \\
\hline Dummies IDENT & \multicolumn{2}{|c|}{ SIM } & \multicolumn{2}{|c|}{ SIM } & \multicolumn{2}{|c|}{ SIM } & \multicolumn{2}{|c|}{ SIM } \\
\hline Dummies IND & \multicolumn{2}{|c|}{ NÃO } & \multicolumn{2}{|c|}{ NÃO } & \multicolumn{2}{|c|}{ NÃO } & \multicolumn{2}{|c|}{ NÃO } \\
\hline Dummies ANO & \multicolumn{2}{|c|}{ SIM } & \multicolumn{2}{|c|}{ SIM } & \multicolumn{2}{|c|}{ SIM } & \multicolumn{2}{|c|}{ SIM } \\
\hline Número de observações & \multicolumn{2}{|c|}{214} & \multicolumn{2}{|c|}{212} & \multicolumn{2}{|c|}{214} & \multicolumn{2}{|c|}{203} \\
\hline $\mathbf{R}^{2}$ & \multicolumn{2}{|c|}{0.245} & \multicolumn{2}{|c|}{0.247} & \multicolumn{2}{|c|}{0.134} & \multicolumn{2}{|c|}{0.463} \\
\hline
\end{tabular}

As variáveis dependentes são EBIT_AT, EBITDA_AT, EBITDA_REC e TOBINSQ, nas colunas i, ii, iii e iv, respectivamente. Estas variáveis foram apresentadas na seção 3.2.3 e referem-se ao período de 2005 a 2007. Os regressores são: IGOV (qualidade de governança corporativa), HHI_4LOW (HHI calculado pela CNAE a 4 dígitos e pertencente à mediana superior), IGOVXHHI_4LOW (interação entre governança IGOV e HHI_4LOW), HHI_3LOW (HHI calculado pela CNAE a 3 dígitos e pertencente à mediana superior), IGOVXHHI_3LOW (interação entre governança IGOV e HHI_3LOW), C4_3LOW (C4 calculado pela CNAE a 3 dígitos e pertencente à mediana superior), NCOMP_4LOW (Competidores considerando CNAE a 4 dígitos e pertencentes à mediana inferior), IGOVXNCOMP_4LOW (interação entre governança IGOV e NCOMP_4LOW), NCOMP_3LOW (Competidores considerando CNAE a três dígitos e pertencentes à mediana inferior), IGOVXNCOMP_3LOW (interação entre governança IGOV e NCOMP_3LOW), 3VDIR (ações ordinárias do três principais acionistas), VOTE (participação das ações ordinárias no capital total da companhia), CRESC (crescimento), LEV(alavancagem), TANG (tangibilidade), SIZE (tamanho), DIVYELD (taxa de dividendos) e os conjuntos de dummies IDENT (tipo do acionista controlador) e ANO. As definições operacionais constam da seção 3.3. Os setores foram separados em competitivos e não competitivos conforme o valor da razão de concentração $\mathrm{C} 4$, tendo como parâmetro os regulamentos do CADE, como descrito na seção 3.5. O erro-padrão de cada coeficiente figura entre parênteses. ***,** e * denotam a significância estatística das estimativas nos níveis de $1 \%, 5 \%$ e $10 \%$, respectivamente. Os erros-padrão foram calculados, para todos os métodos de estimação, utilizando-se os dados agrupados por empresa e são robustos a quaisquer formas de heterocedasticidade e autocorrelação dos erros do modelo. 
ANEXO 


\section{ANEXO 1: QUESTÕES DO ÍNDICE DE GOVERNANÇA CORPORATIVA ELABORADO POR LEAL E CARVALHAL-DA-SILVA (2005)}

Quadro 1-A - Índice elaborado por Leal e Carvalhal-da-Silva (2005)

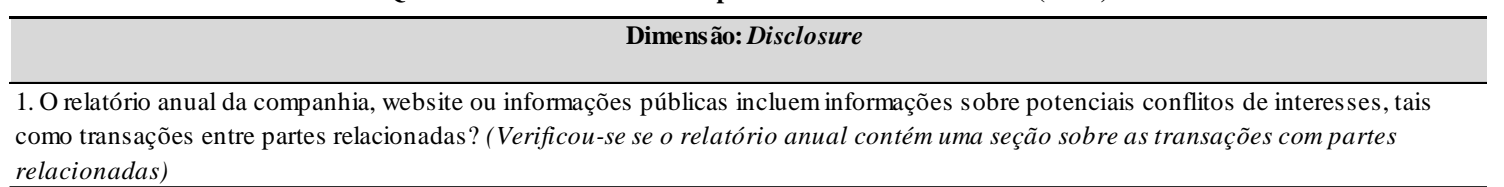
relacionadas)

2. A companhia especifica em seu estatuto, relatórios anuais ou outros meios sanções contra gestores para os cas os de violação das práticas recomendadas de governança corporativa? (Verificou-se se o estatuto corporativo inclui tais sanções)

3. A companhia evidencia os demonstrativos financeiros exigidos legalmente na data prevista? (Verificou-se se a empresa publica os demonstrativos legais até 30 de abril de cada ano, data considerada como limite legal)

4. A companhia se utiliza de padrões internacionais de contabilidade (IASB ou US GAAP)?

5. A empresa se utiliza de uma das firmas de auditoria líderes globais? (as companhias líderes em auditoria são consideradas como sendo PWC, Coopers \& Lybrand, Arthur Andersen, KPMG, Ernst \& Young, Deloitte, Touche \& Tohmatsu)

6. A companhia evidencia em seu website ou nos relatórios anuais informações de remuneração do diretor-presidente e membros do CA? (Verificou-se se a companhia evidencia nos arquivos societários junto à CVC, como IAN, algum tipo de informação de remuneração, mesmo que não descritos individualmente por executivos)

Dimensão: Composição e funcionamento do conselho

7. O presidente do conselho e o diretor-presidente são pessoas diferentes? (Verificou-se se o nome dos presidentes do conselho e do diretor-presidente são os mesmos nos arquivos societários da CVM)

8. A companhia pos sui comitês de asses soramento ao conselho, tais como comitês de remuneração, nomeação e auditoria? (Verificou-se a existência de tais comitês no organograma da companhia)

9. O conselho é claramente formado por membros externos e por diretores independentes?

(Verificou-se se os diretores foram executivos chave na companhia)

10. O conselho apresenta entre 5 até 9 membros, como recomendado pelo Código de Melhores Práticas de Governança do IBGC? (Verificou-se o tamanho do conselho nos arquivos societários da CVM)

11. Os membros do conselho atuam com mandato de um ano consecutivo, como recomendado pelo Código de Melhores Práticas de Governança do IBGC? (Verificou-se a informação de mandato dos membros do conselho nos arquivos societários da CVM)

12. A companhia possui um Conselho Fiscal permanente? (Verificou-se se o conselho fiscal era permanente no organograma da corpanhia)

Dimensão: Ética e conflitos de interesses

13. A companhia é livre de qualquer processo administrativo junto à CVM, referente a más práticas de governança? (Verificou-se se a companhia estava listada entre as empresas investigadas por processos administrativos no website da CVM)

14. A companhia é livre de qualquer condenação ou multa junto à CVM, referente a más práticas de governança ou outras violações em códigos de segurança nos últimos 5 anos? (Verificou-se se a companhia estava listada entre as empresas condenadas ou multadas no website da $C V M$ )

15. A companhia foi submetida à câmara de arbitragem por procedimentos envolvendo casos de más práticas em governança corporativa ao invés da justiça regular? (Verificou-se se a companhia privilegia câmaras de arbitragem em detrimento de procedimentos legais regulares)

16. Os acionistas controladores, considerando os acordos entre acionistas, possuem menos de $50 \%$ das ações votantes? (Verificou-se a porcentagem nos arquivos societários da CVM, considerando 50\% como limite para o controle) 
Quadro 1-A - Índice elaborado por Leal e Carval hal-da-Silva (2005) (continuação)

17. A porcentagem de ações não-votantes em relação ao capital total da companhia é menor do que 20\%? (Verificou-se a informação de número de ações nos arquivos societários anuais da CVM)

18. O coeficiente do direitos sobre fluxo de caixa em relação ao direitos de voto é maior do que 1 para o último acionista controlador? (Verificou-se a porcentagem nos arquivos societários da CVM, considerando 50\% como limite para o controle)

\section{Dimensão: Direitos dos acionistas}

19. As diretrizes ou ações verificáveis da companhia facilitam o processo de voto para todos os acionistas, independente do que é legalmente requerido? (Comparou-se quais as diretrizes que a companhia apresentava em relação aos requerimentos legais até o momento da análise)

20. A companhia confere direitos adicionais de voto, em relação ao que é legalmente requerido? (Verificou-se o que era definido pela companhia, comparativamente ao que era requerido legalmente até o momento da análise)

21. A companhia define direitos de tag along acima do que é legalmente requerido? (Verificou-se o que era definido pela companhia, comparativamente ao que era requerido legalmente até o momento da análise)

22. Estão presentes na companhia es truturas piramidais que diminuem a concentração de controle? (Verificou-se a existência de estruturas de controle indiretos e se essas reduziam a concentração de controle para os último acionista controlador)

23. Existem acordo de acionistas que diminuam a concentração de controle? (Verificou-se a existência de acordo de acionistas e os termos dos acordos para verificar se esses reduzem a concentração de controle dos último acionista controlador)

24. O free-float é maior ou igual ao que é requerido pelo segmento de negociação nível 1 da Bovespa (25\%)? (Verificou-se nos arquivos societários da CVM se o free float declarado é superior a $25 \%$ )

FONTE: Traduzido de Leal e Carvalhal da Silva (2005). 